\title{
Pacific Northwest Laboratory Annual Report for 1978 to the DOE Assistant Secretary for Environment
}

Part 2 Ecological Sciences February 1979

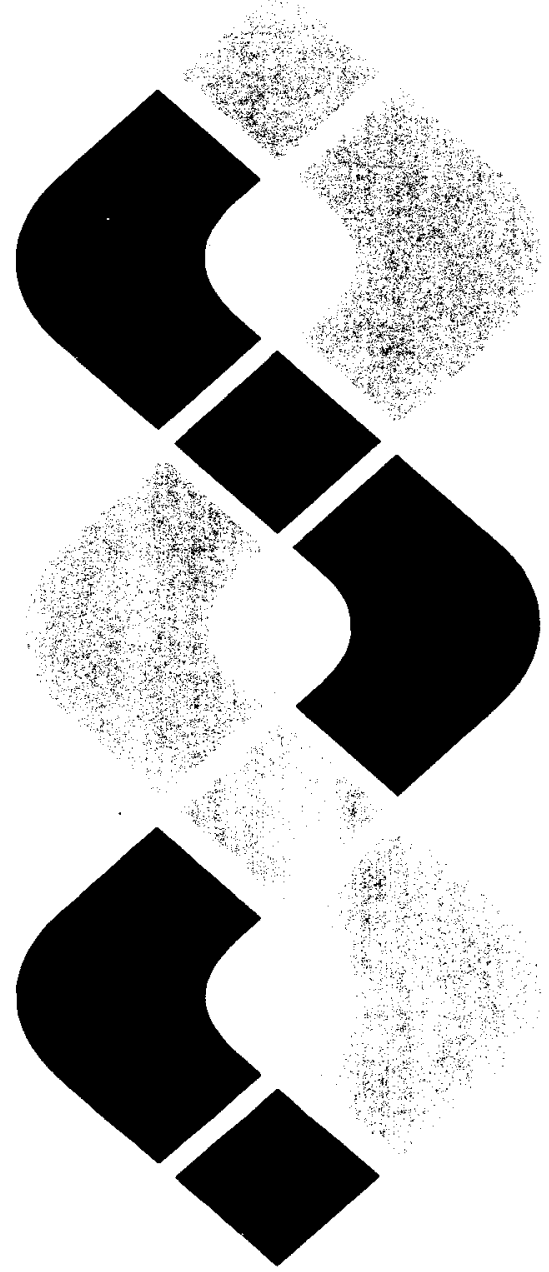

Prepared for the U.S. Department of Energy under Contract EY-76-C-06-1830

Pacific Northwest Laboratory Operated for the U.S. Department of Energy by Battelle Memorial Institute 


\title{
NOTICE
}

This report was prepared as an account of work sponsored by the United States Government. Neither the United States nor the Department of Energy, nor any of their employees, nor any of their contractors, subcontractors, or their employees, makes any warranty, express or implied, or assumes any legal liability or responsibility for the accuracy, completeness or usefulness of any information, apparatus, product or process disclosed, or represents that its use would not infringe privately owned rights.

The views, opinions and conclusions contained in this report are those of the contractor and do not necessarily represent those of the United States Government or the United States Department of Energy.

\author{
PACIFIC NORTHWEST LABORATORY \\ operated by \\ BATTELLE \\ for the \\ UNITED STATES DEPARTMENT OF ENERGY \\ Under Contract EY-76-C-06-1830
}

Printed in the United States of Am
Available from
National Technical Information Se
United States Department of Commer
5285 Port Royal Road
Springfield, Virginia 22151
Price: Printed Copy \$_* Microfich




\section{Pacific Northwest Laboratory Annual Report for 1978 to the DOE Assistant Secretary for Environment}

\section{Part 2 Ecological Sciences}

B. E. Vaughan and Staff Members of Pacific Northwest Laboratory

February 1979

Prepared for the U.S. Department of Energy under Contract EY-76-C-06-1830

Pacific Northwest Laboratory

Richland, Washington 99352 


\section{PREFACE}

The 1978 Annual Report from Pacific Northwest Laboratory (PNL) to the DOE Assistant Secretary for Environment is the first report covering a full year's work under the Department of Energy since it came into existence on Octnber 1, 1977. Most of the research conducted during this period and described in this report was begun under the Energy Research and Development Administration or its predecessor agency, the Atomic Energy Commission. However, several new projects have enhanced the PNL emphasis on environment, health and safety research in the area of synthetic fuels. Preliminary reports on these efforts are spread throughout the five parts of this annual report.

The five parts of the report are oriented to particular segments of our program. Parts 1-4 report on research performed for the DOE Office of Health and Environmental Research. Part 5 reports progress on all other research performed for the Assistant Secretary for Environment including the Office of Technology Impacts and the Office of Environmental Compliance and Overview.

Each part consists of project reports authored by scientists from several PNL research departments, reflecting the interdisciplinary nature of the research effort. Parts 1-4 are organized primarily by energy technology, although it is recognized that much of the research performed at PNL is applicable to more than one energy technology.

The parts of the 1978 Annual Report are:

Part 1: Biomedical Sciences

$$
\text { Program Manager - W. R. Wiley D. L. Felton, Editor }
$$

Part 2: Ecological Sciences

$$
\begin{aligned}
\text { Program Manager - B. E. Vaughan } & \text { B. E. Vaughan, Report Coordinator } \\
& \text { C. H. Connally, Editor }
\end{aligned}
$$

Part 3: Atmospheric Sciences

$$
\begin{aligned}
\text { Program Manager - C. L. Simpson } & \text { R. L. Drake, Report Coordinator } \\
& \text { P. R. Partch/C. M. Gilchrist, Editors }
\end{aligned}
$$

Part 4: Physical Sciences
Program Manager - J. M. Nielsen
3. M. Nielsen, Report Coordinator
J. S. Burlison, Editor 
Part 5: Environmental Assessment, Control, Health and Safety.

Program Managers - N. E. Carter

D. B. Cearlock

D. I. Hessel

S. Marks W. J. Bair, Report Coordinator

C. M. Unruh R. W. Baalman, Editor

Activities of the scientists whose work is described in this annual report are broader in scope than the articles indicate. PNL staff have responded to numerous requests from $00 E$ during the year for planning, for service on various task groups, and for special assistance.

Credit for this annual report goes to many scientists who performed the research and wrote the individual project reports, to the program managers who directed the research and coortinated the technical progress reports, to the editors who edited the individual project reports and assembled the five parts, and to Dr. Ray Baalman, editor in chief, who directed the total effort.

W. J. Bair, Manager

S. Marks, Associate Manager

Environment, Health and Safety Research

Program

Previous Reports in this Series:

Annual Report for

\begin{tabular}{|c|c|}
\hline $\begin{array}{l}1951 \\
1952 \\
1953 \\
1954 \\
1955 \\
1956 \\
1957 \\
1958 \\
1959 \\
1960 \\
1961 \\
1962 \\
1963 \\
1964 \\
1965 \\
1966 \\
1967 \\
1968 \\
1969 \\
1970 \\
1971 \\
1972 \\
1973 \\
1974 \\
1975 \\
1976 \\
1977\end{array}$ & 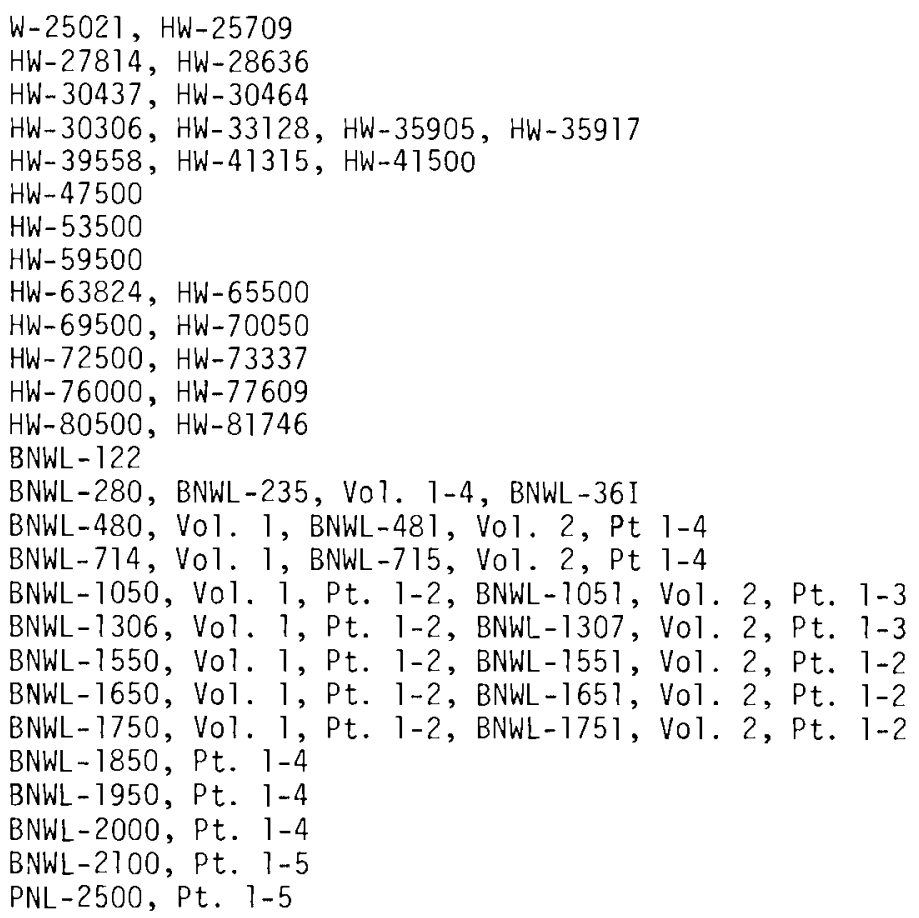 \\
\hline
\end{tabular}




\section{FOREWORD}

In Part 2 of these volumes, a11 work funded in the Ecological Sciences by OHER has been brought together. This covers ecological effort in the following budget activity categories:

G - Environment

GK - Multi-Resource

GK-01-02-03-1

Identification Transport and Conversion

GK-01-02-03-2

Environmental Effects of Energy-Related Processes and Pollutants in the Environment

GK $-01-02-03-3$

Energy-Related Supporting Research

GK $-01-02-03-4$

Environmental Dperations and DOE Support Activities

For convenience, organization charts for the several participating departments and sections of PNL can be found at the back of the report.

Wherever possible, we have grouped the individual research projects (Schedule 189's) according to the energy technology they primarily support. It is important to recognize, in some other cases, that certain environmental processes are common to several technologies (e.g., impact of cooling systems operation on fisheries), and in these cases the individual research projects are grouped under the Multitechnology section of this report. In the abstracts that follow, principal investigators are listed who may be contacted for further information about individual projects. This format should make the report useful not only to OHER, but to managers of technology programs as well. We hope the technology manager can go to an appropriate section of this report set off by a blue divider page, then immediately find those ecological problems investigated by PNL that may be pertinent to his concerns. In several instances (e.g., the shale oil program) coordinated efforts lie in the biomedical and organic chemistry areas outside the purview of this report. In those instances we have inserted cross references to the appropriate volume of the five-volume Annual Report, of which this is one part.

PNL's direct experience with the oil and utility industries, and with other agencies concerned with energy installations, has contributed in a particularly pertinent way to the understanding of the major environmental problems that the technologies will need assistance in solving. Not all of our prior work is reported herein. All work for other agencies and industry, however, can be located in the bibliography named below, a separate publication. (a)

Several projects funded specifically on the basis of interagency agreement with DoE are, however, briefly described in Section 11 of this report.

In our ongoing discussions with technology representatives, a frequent misunderstanding occurs concerning the purposes of DOE work in the ecological sciences and concerning the usefulness of the quantitative data developed in these programs. Basically, the ecological programs are designed to assist the technologies in meeting the intent of the National Environmental Policy Act (NEPA). In meeting this objective, part of the work is designed to anticipate problems "around-the-corner," so that the developing technology may be suitably modified before major capital investment is committed. The projects described under the Multitechnology section of this report fit another category. Here the effort is either "generic" (i.e., applying to several technologies) or theoretical. The theoretical work, particularly, is concerned with providing an improved basis from which rational environmental standards can be derived. In many situations, current measurements of ecological processes are highly provisional, without adequate statistical basis, and better suited as order-of-magnitude estimates on $1 y$. In these areas, it is in the interest of the technologies that a better groundwork be laid for subsequent activities of the agencies responsible for setting standards.

During the past year, effort has intensified regarding OHER coordination of its projects with those of other components and agencies. Counterpart PNL contributors have been participating in these efforts and are so indicated in the text and, in summary, on the organization charts at the end of this report. In addition, Raymond E. Wildung (PNL) has continued as a member of the NAS/NRC Committee on Accessory (Trace) Elements, and the Coal, 0il Shale and 
Uranium sub-panels; Richard F. Foster (PNL) has continued assistance with NRC's Environmental Standard Review Plans; and William L. Templeton (PNL) has continued serving on the Marshall Is 1 ands Advisory Group.

Although the Hanford National Environmental Research Park (Hanford NERP) was dedicated on March 18, 1977, it has functioned for over a decade on a more restricted basis as the Arid Lands Ecology (ALE) project. Now, well over thirty dissertation projects have been sponsored by PNL, consistent with NERP objectives, and the ALE Reserve appears to be the only national location that has been maintained fully to NSF standards as a Biosphere Reserve. In establishing the Hanford NERP, major segments of the 750-square-mile site have been set aside for applied research in ecology, open to all qualified research scientists. Charter intent is to stimulate 1) baseline observations, 2) field studies of response to man-made disturbances, 3) predictive modeling of impacted ecosystems and 4) public demonstration of alternate land use at the energy activity sites. Use policy and procedures have evolved from those developed earlier on the ALE Reserve. Within the Hanford NERP, the ALE Reserve (110 square miles) remains a protected area intended for long-range modulation studies (i.e., nondestructive studies) of grasslands and desert shrub-steppe ecosystems, and the data established for this type of landscape become of major importance in dealing with landscape rehabilitation efforts. A descriptive summary of the data base and prior research conducted at the Hanford NERP is now available. (b)

Burton E. Vaughan Subprogram Manager Ecological Sciences

(a) A Bibliography of Environmental Research BNWL-SA-4655, Rev. 3

Ecosystems Department

Pacific Northwest Laboratory

P.0. Box 999

Richland, WA 99352

(b) B.E. Vaughan and W.H. Rickard Hanford National Environmental Research Park (NERP) A Descriptive Summary of the Site and Site-Related Research Program, 1952-1977

PNL-2299

Ecosystems Department

Pacific Northwest Laboratory

P.0. Box 999

Richland, WA 99352 


\section{CONTENTS}

PREFACE

FOREWORD

1.0 NATIONAL ENVIRONMENTAL RESEARCH PARK AND LAND USE

Hanford National Environmental Research Park Ecological Monitoring for Long-Term Effects

$\begin{array}{lcc}\text { Educational Use } & \cdot & \\ \text { Research Use } & & \\ \text { Other NERP Projects } & \text { and } & \text { Concerns } \\ \text { Terrestrial Effects } & . & \cdot \\ \text { Aquatic Effects } & . & .\end{array}$

Terrestrial Ecology Restoration of Surface-Mined Lands

Self-Revegetation of Disturbed Ground: Longer-Term Aspects Self-Revegetation of Replowed Cheatgrass Communities:

Short-Term Aspects

Microtopography and the Vegetative Recovery of steep siopes Leaffall in Desert Shrubs as a Method for Long-Term Mon itoring of Ecological Trends

Pheno logy Studies.

Astragalus columbianus: An Endangered Plant Species on

the Hanford Site.

Bats of the ALE Reserve

Bald Eagles Wintering on the Hanford Site, 1977

A Comparison of Two Gul1 Nest Census Techniques. Abundance of Large and Medium-Sized Animals on the Hanford Site Consumer Food Habits, Beetles and Ground Squirrels

Slope Treatment, Water Harvest and Crop Yields, 1978

\subsection{SHALE OIL}

Terrestrial Effects of 0 il Shale Development $\quad . \quad \ldots \quad$. $\quad . \quad$. $\quad$. 2.3

Properties of Effluents Disposed to the Ground--Organic Solubles . $\quad 2.3$

Solvent Solubilization of Organic Compounds in Retort Water. . . . 2.4

Properties of Effluents Disposed to the Ground--Retorted Shale . $\quad . \quad 2.5$

Mobility of Soluble Inorganic and Organic Residuals . . . . . . 2.5

Microbiology of Effluents Disposed to the Ground . . . . . . 2.6

Physiological Effects of Effluents on Plants $. \quad . \quad . \quad . \quad . \quad 2.8$

\subsection{SYNFUELS}

Synfue ls

Acute Toxicity of Solvent Refined Coal Effluents--Toxicity Tests . . 3.3

Chemical Characterization of Solvent Refined Coal Effluents. . . 3.5

Effects of Sublethal Phenol Exposure on Predator-Prey Relationships . 3.6

Effects of Phenol on Gill Adenosine Triphosphatase . . . . 3.6

\subsection{OIL AND GAS}

Fate and Effects of Petroleum Hydrocarbons in Marine Coastal Ecosystems • $\quad 4.3$

Potential Effects: Laboratory Studies

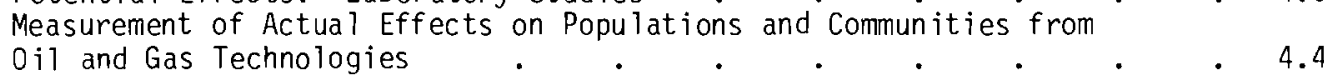


Long-Term Effects of Hydrocarbons on Selected Ecosystems

and Associated Organisms

Characterization of the Flowing Exposure System

Analytical Procedures to Ensure Internal Consistency Uptake of Hydrocarbons From the Flowing System.

Toxicity Indices of Selected Marine Species

\subsection{NUCLEAR WASTES: FISSION}

Transuranic Behavior in Soils and Plants . . . . . . . . . . . 5.3

So il-Plant-Animal Studies

Foliar Studies

Quantitative Aspects of Plutonium Field Studies ..$\quad$. $\quad$. 5.7

TRAN-STAT: Statistics for Environmental Transuranic Studies $\quad$ • 5.7

Statistical Analysis of Ratio Data . . . . . . 5.7

North Marsha 11 Is lands Advisory Group on Cleanup of Enewetak Atoll $1^{*} \quad 5^{*} .8$

Nevada Test Site (NTS) Environmental Transuranic Studies . . . 5.8

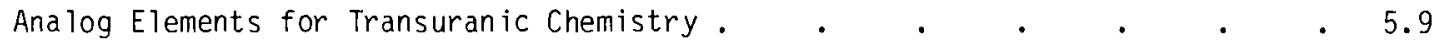

Patterns of Rare Earth Analog Elements in Biological Materials . $\quad$ - 5.9

$\begin{array}{lll}\text { Availability of Native Rare Earth Elements and Fallout Transuranic } \\ \text { Elements from Soils to Plants. } . . & . & 5.10\end{array}$

Transuranic Weathering in Plants . . . . . . . . . . $\quad$. 5.13

Comparative Uptake and Distribution of Transuranics in Range and Crop Plants

Plutonium Movement Within a So il Column :

Placement of 239 Pu-0xide into Field Lysimeters.

Radioecology of Nuclear Fuel Cycles . $\quad . \quad \ldots \quad$. $\quad . \quad$. $\quad$. 5.17

Aquatic Radioecology of Waste Management Areas . $\quad . \quad$. $\quad . \quad$. $\quad 5.18$

Terrestrial Radioecology of Waste Management Areas . . . . . $\quad$. 5.19

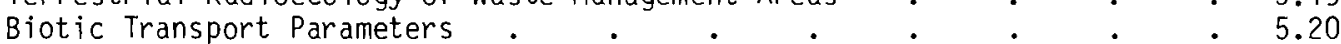

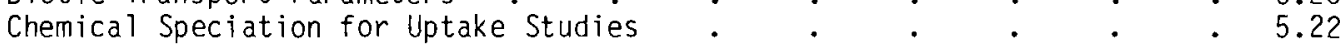

Environmental Behavior and Effects of Technetium-99 and Iodine-129 • $\quad 5.25$

Mechanisms of Technetium Toxicity to Plants at the Cellular Level . $\quad 5.26$

Behavior of Technetium in Aquatic Systems.

Behavior of Iodine in the Plant Soil System

Iodine-129 in the Hanford Environment

\subsection{NUCLEAR FUSION}

Sublethal Effects of Tritium on Aquatic Systems. Effects of Lithium and Beryllium on Aquatic Systems Teratogenic Effects of Low-Level Magnetic Fields

Sublethal Effects of Tritium on Aquatic Systems

Ecological Effects of Lithium and Beryllium on Important Aquatic

Organisms and Associated Communities

Chronic and Acute Toxicity

Commun ity Response

Teratogenic Effects of Low-Level Magnetic $\dot{F}$ ields \\ 7.0 SOLAR/HYDROELECTRIC GENERATION}




\subsection{SATELLITE POWER SYSTEMS}

Investigation of Microwave Effects on Terrestrial Ecosystems (Proposed)

Characteristics of the Field Exposure System Possible Ecological Studies Documentation of the Planning Done to Date

\subsection{MULTITECHNOLOGY AND SUPPORTING RESEARCH PROGRAMS}

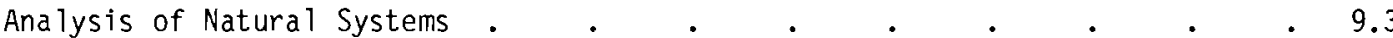

Statistical Aspects of Environmental Contamination $\quad . \quad$. $\quad$. $\quad 9.3$

Biostatistical Aspects of Environmental Impact Analysis $\quad$. $\quad . \quad$. 9.3

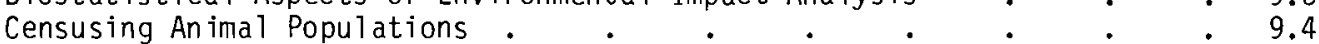

Mechanisms for Animal Population Regulation $\quad . \quad$. $\quad . \quad$. $\quad . \quad$. $\quad 9.4$

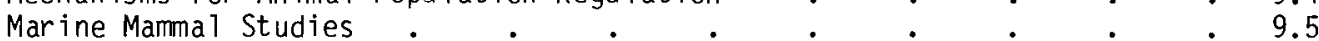

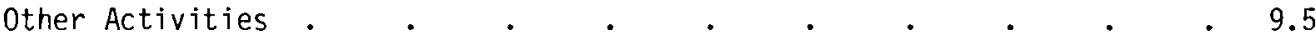

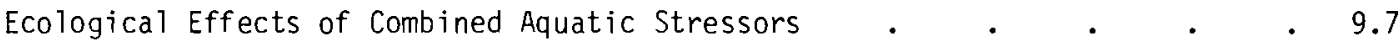

The Combined Effects of Nickel, Chlorine and Temperature on Rainbow Trout

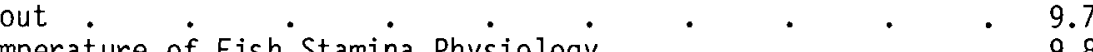

Effects of Energy Systems Effluents on Coastal Ecosystems . . . . 9.11

Disruption of Magnesium Regulation in the Crab Cancer productus

Exposed to Chlorinated Seawater $\quad \cdot \quad \cdot \quad \cdot \quad \cdot \quad \cdot \quad \cdot 9.11$ Effects of Chlorinated Seawater on the Littleneck Clam $\quad . \quad \cdot \quad \cdot \quad 9.11$ Tissue Copper Levels in Protothaca staminea Exposed to Assay for Sodium-Potassium Adenosine Triphoshatase in $\dot{G}^{\circ} i l$ s $^{\circ}$ of Protothaca $\quad . \quad \cdot \quad \cdot \quad \cdot \quad \cdot 9.12$ Effect of Copper on Eudistylia vancouveri $: \quad \cdot \quad \cdot \quad \cdot \quad \cdot \quad \cdot \quad \cdot \quad \cdot \quad 9.12$ Effect of Copper on the Littleneck Clam . . . . . . . . . . 9.13

Bioavailability of Energy Effluent Materials in Coastal Ecosystems $\quad$ • $\quad 9.15$

Marine Chemistry of Energy-Generated Pollutants $\quad . \quad$. $\quad . \quad$. $\quad . \quad 9.19$ In Situ Pollutants 9.19

The Solubility of Airborne Particulate Elements When Added to Seawater.

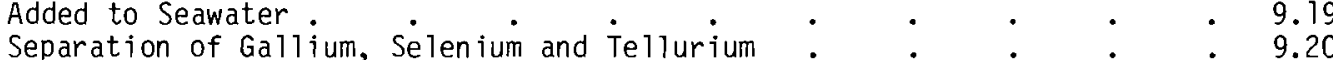

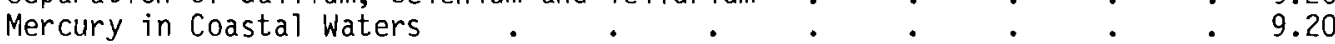
Elemental Characterization of the International Atomic $\quad 9.21$ In Situ Pollutants: Analysis of Sediments by $X-\dot{R} a y$ Fluorescence : $\quad$ - 9.21

DOE-Funded Oceanographic Cruises •.

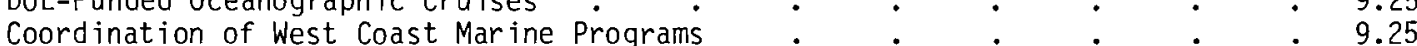

\subsection{HANFORD PROJECT SUPPORT}

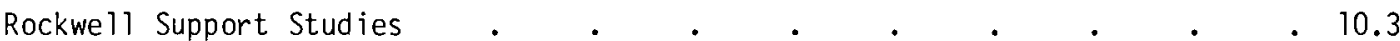

Burrowing Animal Studies - Ants . . . . . . . . 10.3

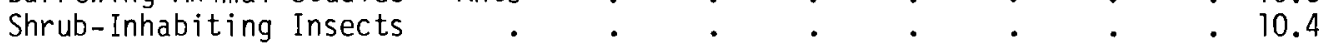

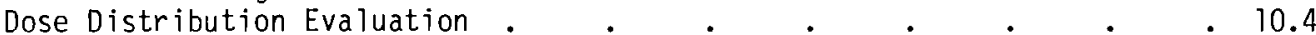

Environmental Assessment of Raptors : $\quad \cdot \quad \cdot \quad \cdot \quad \cdot \quad \cdot 10.6$

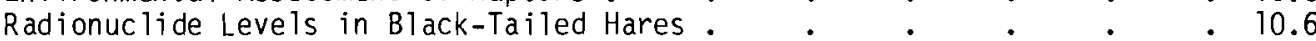

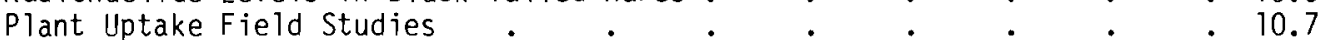

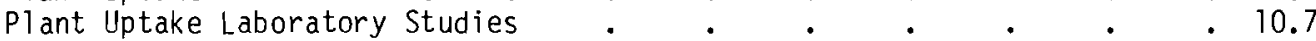

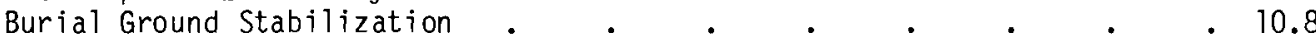


Decommissioning and Decontamination (300 Area Burial Ground) Studies • 10.9

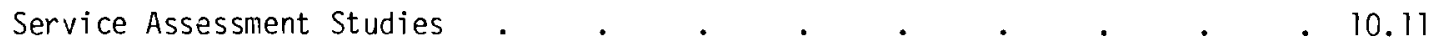

Fall Chinook Salmon Spawning Near Hanford, 1977 . $\quad$ • . . 10.11

11.0 ENERGY RESEARCH FOR OTHER AGENCIES

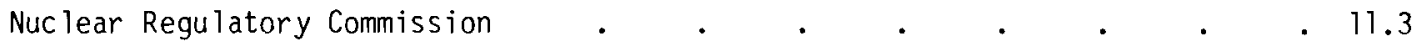

Biocide Byproducts in Aquatic Environments $\quad . \quad \ldots \quad . \quad$. $\quad . \quad 11.3$

Application of Fisheries Management Techniques to Assessing Impacts $\quad 11.6$

Quantitative Assessment of Aquatic Impacts of Power Plants . . . 11.6

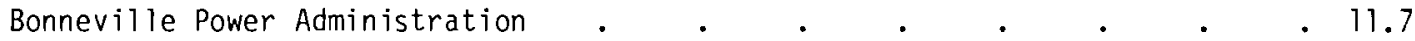

Biological Studies at the Site of a 1200-KV Prototype $\quad . \quad 11.7$

Electric Power Research Institute $\quad$. $\quad . \quad$. $\quad . \quad$. 11.11

Synthesis and Analysis of Cooling Impoundment Information $\quad . \quad e_{11} \quad$ 11.11

Effects of Coal-Fired Power Plant Emissions on Vegetation

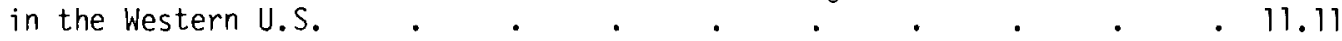

National Oceanic and Atmospheric Administration/Bureau of Land Management $\quad 11.12$

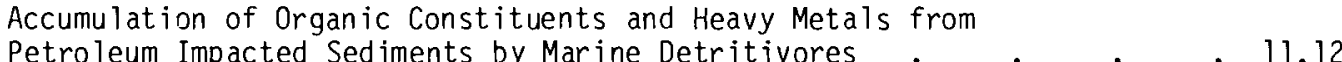

Effects of Petroleum Hydrocarbons on the Behavior of

National Institute of Environmental and Health Sciences $\quad . \quad . \quad . \quad .11 .13$

Fate of Heavy Metals and Heavy Metal Complexes in $\ldots$. . . 11.13

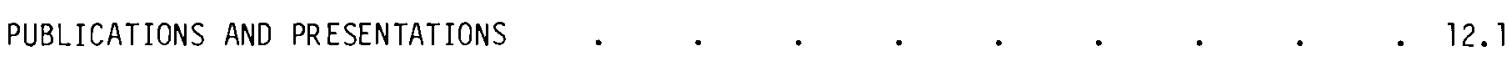

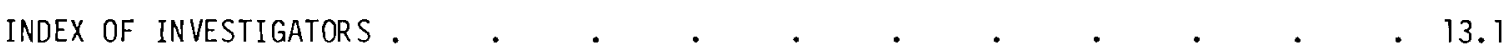

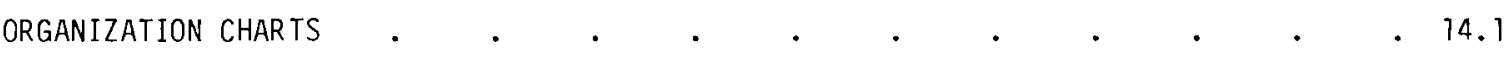

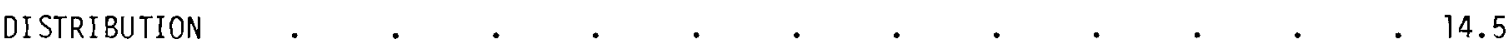




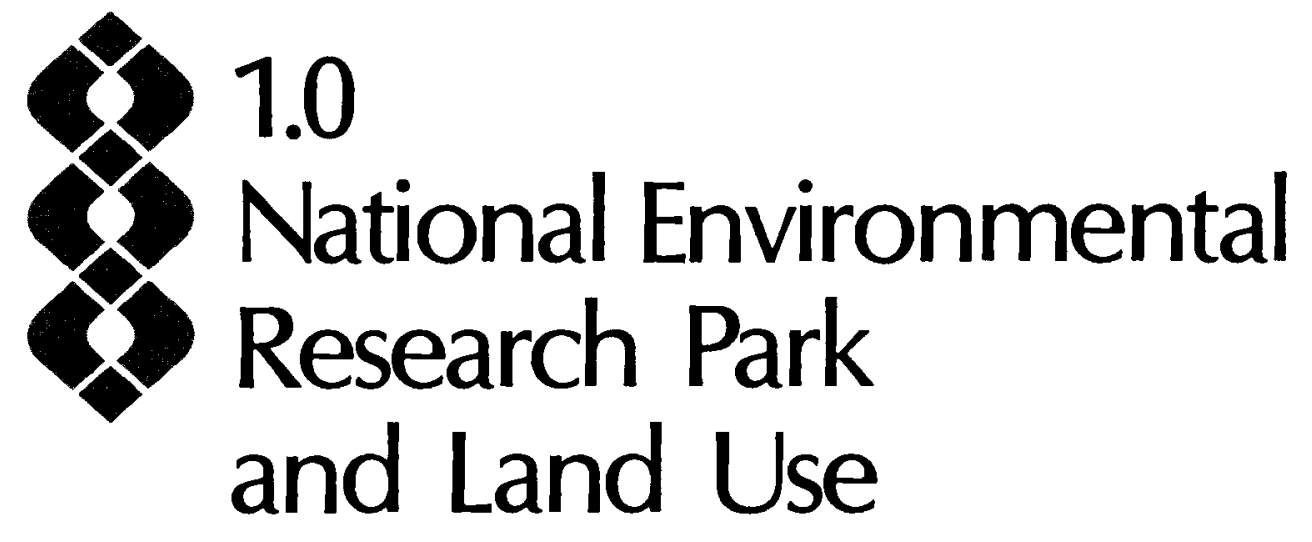




\section{NATIONAL ENVIRONMENTAL RESEARCH PARK AND LAND USE}

- Hanford National Environmental Research Park

- Ecological Monitoring of Long-Term Effects

- Terrestrial Ecology

\section{- Restoration of Surface-Mined Lands}

Historically, man has exploited the biologic productivity of land to sustain an increasing human population. Most of the land area in the United States is used to produce food, fiber and wood products. Increased food production has been possible because of energy derived from fossil fuel, nuclear fuel and hydroelectric dams. Some of the byproducts of the operation of energy facilities are released into the air, into surface- and groundwater or buried in the earth. Some residuals are potentially toxic to man, domestic or wild animals, and plants. The purpose of research in land use is to quantify the environmental (ecological) impacts of expanding energy technologies including extraction of the resource, construction of facilities, operation of facilities and the disposal of wastes.

The U.S. Department of Energy has extensive land holdings in the arid and semi-arid regions of the western United States. One of the most strategically situated land holdings is in the State of Washington. The Hanford Site currently contains the obsolete facilities developed for wartime plutonium production and also stores large amounts of radioactive waste materials. To provide additional health and safety measures, the production facilities were buffered by a large land area unoccupied and unused by people. Today, this buffer zone provides some of the least disturbed and therefore most desirable land for long- and short-term terrestrial and aquatic ecological baseline research in the United States. In recognition of this research potential, the Arid Lands Ecology Reserve and the Hanford National Environmental Research Park were established to promote the use of the Hanford Site for ecological research, and especially for studies related to energy technologies and their potential for environmental impacts in semi-arid regions.

Throughout 1978 Annual Report:

- Bullets denote 189 titles.

- ${ }^{\circledR}$ Use of brand name does not imply Battelle endorsement. 
Long-term ecological monitoring studies at PNL are designed to detect and evaluate subtle but potentially harmful effects on aquatic and terrestrial ecosystems induced by long-term operations of energy facilities in the northwestern United States. Similar studies in the southeastern United States are conducted by the Oak Ridge National Laboratory.

Most terrestrial ecology studies are conducted on the Hanford Site. These are concerned with short- and long-term energy technology impacts, construction and operationa! impacts, and natural perturbations in shrub-steppe ecosystems. These projects provide the kind of ecological information needed to achieve the purposes of the National Environmental Policy Act (NEPA) as well as advancing the state of ecological knowledge in the scientific community at large. Land restoration studies, located in Washington and in Arizona, are aimed at testing alternative ways to successfully revegetate surface-mined lands in the most arid parts of the western United States.

This section of the Annual Report is divided into two parts. The first discusses the studies on and uses of the Hanford National Environmental Research Park and studies concerning long-term ecological monitoring. The second deals with land use studies. These consist of terrestrial ecology studies and investigation of surfacemined land restoration. 


\section{- Hanford National Environmental Research Park}

\section{- Ecological Monitoring for Long-Term Effects}

Principal rnvestigators: W. H. Rickard, W. T. Hinds, D. H. Mckenzie, K. S. Baker, C. D. Becker and C. E. Cushing

The Hanford National Environinental Research Park (NERP) includes the Arid Lands Ecology (ALE) Reserve, a $310 \mathrm{~km}^{2}$ land area located on the western edge of the Hanford Site, in southcentral Washington. It is deficated to ecologicai research. One of the aims of the NERP concept is to promote use of designated lands for research and educational purposes, which is being done on the ALE Reserve.

The research conducted in the long-term ecological monitoring tasks is concerned with both terrestrial and aquatic ecosystems. Terrestrial ecology tasks are designed to detect subtle long-term buildups of potentially harmful airborne poliutants in terrestrial ecosystems in the northwestern United States. This will provide an early warning of harinful effects to high trophic level animals or potentially widespread loss of primary productivity as a result of chemical pollution associated with a variety of expanding energy technologies, especially fossil fuels. Tasks in aquatic ecology are intended to detect subtle changes in the chemical and/or physical properties of lakes and streams that might be deleterious to fish and other valuable aquatic species.

\section{HANFORD NATIONAL ENVIRONMENTAL RESEARCH PARK}

\section{Educational Use}

During calendar year 1978, three graduate theses were completed by students(a) whose ecologically-oriented research was conducted on the National Environmental Research Park at Hanford. The authors, titles of dissertations, names of sponsoring universities, and brief abstracts of the research are given below.

W. D. Steigers, M.S., Brigham Young

University

Mortality of Mule Deer Fawns in

Southcentral Washington

Thirty-nine mule deer (Odocoileus hemionus) $f$ awns were captured on the Hanford $S$ ite in the spring of 1977 . The fawns at capture ranged between 1 and 24 days old and weighed $2 \mathrm{~kg}$ to $9.7 \mathrm{~kg}$. Fawns were fitted with radiotransmitters and their movements monitored

(a) Students have access to NERP Facilities through the NORCUS Program, which provides graduate student stipends. each day from May through August and once monthly during September through December. The average distance traveled by fawns from the previous day's location during the first three months of life was $438 \mathrm{~m}$. Fourteen of the tagged fawns died. Ten were killed by coyotes and three drowned. The mean home range for fawns older than 60 days was 254 ha. Such a large home range is attributed to marginal habitat conditions.

$$
\begin{aligned}
& \text { J. T. Rotenberry, Ph.D., Oregon State } \\
& \text { University } \\
& \text { Ecological Relationships Among } \\
& \text { Shrub-Steppe Birds: Competition or } \\
& \text { Opportunism in a Variable Environment? }
\end{aligned}
$$

The dietary relationships within a guild of three ground-foraging passerine shrubsteppe birds--horned lark (Eremophila alpestris), sage sparrow (Amphispiza belli) and western meadowlark (Sturnella neglecta)-were studied. General dietary anaTysis indicated a strong temporal influence on birds selection of food; different species collected at the same time ate the same foods while members of the same species collected at different times ate different foods. In 
general, differences in body size or bill length were insufficient to account for variations in prey size, although on occasion the meadowlark took larger prev items than did the smaller horned larks and sage sparrows. Average prey size was significantly correlated with the proportion of seeds in the diet and varied seasonally as seed consumption varied.

Shrub-steppe passerines are largely opportunistic rather than optimal in their foraging and diet selection. The apparent absence of "fine tuning" to their competitive milieu is most likely a function of the variable environment in which they coexist.

J. N. Fitzner, Ph.D., Washington State University

The Ecology and Behavior of the

Long-billed Curlew (Numenius americanus) in Southeastern Washington

Breeding territories of the long-billed curlew are located mostly in dry areas of short, patchy grass. The territories are well defined and are occupied from year to year. Birds arrive on breeding territories in the spring either in pairs or as single males soliciting for a female. Most agonistic displays and postures involved with sexual behavior are performed by the male. On the Hanford Site, pre-hatching territory varies in size from 15 to 50 ha depending on the habitat. After hatching, only the area in the vicinity of the chicks is defended.

Once the nest site is selected, four eggs are laid at 48-hr intervals. Eggs are sometimes 1ost, many of them taken by magpies (Pica pica) and coyotes (Canis latrans). If an entire clutch is lost the parent birds abandon their territory. Hatching is synchronized within nests and also within each general nesting area. Chick mortality is very high. Though the causes are uncertain, predation, weather and external disturbances during hatching are undoubtedly involver.

Up to 250 long-billed curlews congregate on Island 3 in the Columbia River for one to two weeks during late summer flocking. Groups of 30 individuals or fewer leave from this staging area in the late afternoon and presumably head south in migration.

\section{Research Use}

Professional researchers used the Hanford NERP in 1978 as an outdoor laboratory to augment ecological studies funded by agencies other than the Department of Energy, Office of Health and Environmental Research. The names of these researchers and brief descriptions of their activities on the Hanford NERP appear below.

\section{Dr. J. Kenagy, University of Washington}

Kenagy's research, funded by the University of Washington and the National Science Foundation, seeks to elucidate the ecological and physiological factors that initiate and govern reproduction in desert-dwelling rodents. The Hanford NERP is a useful study site because of the large population of pocket mice (Perognathus parvus) and the longterm protection that the NERP offers the sinub-steppe habitat.

Dr. R. N. Mack, Wastington State

University

This study attempis to tiscover the competitive relationships between annual and perennial grasses in rangeland habitats in the nonforested region of southeastern Washington. The Hanford NERP is useful for this kind of research because of the longterm protection it offers to study locations and because the 1 ands at the Hanford NERP represent the arid extreme on the climatic gradient in the nonforested regions of Washington. This research is sponsored by Washington State University and the National Science Foundation.

\section{Other NERP Projects and Concerns}

A role of the NERP is coordinating wildlife research activities with state and federal agencies that manage those wildlife species associated with Hanford NERP habitats. The Hanford NERP helps protect critical wildife habitats and recommends mitigating actions to ameliorate any loss of habitat caused by energy development activities. The NERP administration also is respons ible for far-sighted avoidance of potential legal action.

\section{Game Animals}

Information meetings were held in 1978 with Mr. Ellis Bowhay, Washington Game Department biologist, concerning the status of the American elk (Cervus canadensis) on the Hanford NERP. Of particular concern was the potential for elk to leave the site and damage crops of neighboring private farms and ranches. Also of interest was the nesting population of the Canada goose (Branta canadensis) and the heavy predation induced by the coyote (Canis latrans) in recent years.

\section{Non-game Animals}

Informal meetings were held with biologists of the Washington Game Department and the U.S. Fish and Wildlife Service concerning research and management of non-game species such as the prairie falcon (Falco mexicanus), Swainson's hawk (Buteo swainsoni), ferruginous 
haivk (Buteo regalis), burrowing owl (Speotyto cunicularia), bald eagle (Haliaeetus TeucocephaTus) and the long-billed curlew (Numenius americanus).

\section{Migratory Waterfow 1}

Historically the Columbia River as it flows through the Hanford NERP has been a resting stop for large flocks of ducks and geese. For the first time in 35 years the Columbia River will be entirely open to unrestricted boat traffic. Increased boating use will probably discourage the use of the Columbia River by resting waterfowl. New lakes created on the Hanford NERP by the U.S. Bureau of Reclamation and managed by the U.S. Fish and Wild ife Service as the Saddle Mountain Wildlife Refuge will probably become more attractive to migrating waterfowl.

\section{Endangered Species}

A plant on the U.S. Fish and Wildlife Service's endangered species list occurs on the Hanford Site. This species, Astragalus columbianus, is described in detail in the Tand use section of this report.

\section{Bird-Banding and Collecting Permits}

All bird-banding and marking studies conducted on the Hanford NERP are done so with the approval of the U.S. Fish and Wildi ife Service Bird-Banding Laboratory. Animals collected for scientific purposes receive written approval from the Washington State Game Department and/or the U.S. Fish and Wildlife Service.

\section{Fire}

A man-induced fire burned over seven or eight thousand hectares of sagebrusi-grass habitat in July 1978. The fire, the largest of the year, was mostiy confined to the ALE Reserve. New roads and vehicle tracks were made by fire-fighting crews. These marks on the 1 and will be visible for many years, even after fire damage has mostly disappeared.

\section{Stray Livestock}

There were no instances of stray livestock intrusion on the ALE Reserve in 1978. A few stray horses (less than 10) have occupied the west bank of the Columbia River south of the old Hanford Village townsite for several years.

\section{High Voltage Transmission Lines}

The Bonneville Power Administration (BPA) is presently constructing a new transmission line. The line crosses the ALE Reserve as it leaves the Hanford NERP to the west. It crosses the Columbia River on the east boundary in the vicinity of Ringold.

\section{Hydroelectric Dam}

The U.S. Army Corps of Engineers is contemplating future dam construction on the Columbia River on the Hanford Site. The proposed location is between the 300 Area and Ringold. This dam would displace wildlife and fish populations on the Hanford NERP.

\section{Decommissioning and Decontamination}

Future decommissioning of a number of obsolescent nuclear facilities on the Hanford Site is being contemplated. Shallow burial of debris having low levels of radioactive contamination will probably occupy large sections of 1 and, creating a need for 1 and restoration and wildlife protection.

\section{Hanford Nuclear Energy Center}

One of the proposed future uses of 1 and at the Hanford Site is the development of a complex of about 20 nuclear power reactors. it is likely that many operating cooling towers will release moisture and salt over considerable expanses of the Hanford NERP as well as adding heat and minerals to the Columbia River. The number of transmission lines crossing the Hanford Site will also be increased, affecting wildlife and considerable land removed from biological productivity by buildings and ancillary structures.

\section{ECOLOGICAL MONITORING FOR LONG-TERM EFFECTS}

\section{Terrestrial Effects}

The nortinwestern United States is expecting a rapid increase in energy facility sitings. These may include a variety of energy technologies, such as coal combustion, solvent-refined coal, and coal conversion. All of these have the potential for dispersal of fine particles and gaseous releases into the air, and therefore the potential for biological damage. Because of the increased activity, collection of long-term baseline data in the varied forest ecosystems of the Northwest was begun in 1978 .

Sites for this long-term study have been sought in areas having administrative or statutory protection against intentional ecosystem disturbance (i.e., logging) for the next several decades, at least. Federal Research Natural Areas are prime candidates for such sites. Five sites have been selected in Washington and Oregon, with two others being seriously considered (Figure 1.1). The potential relationship between these sites and energy facility development is indicated by the counties called out in the figure. 
(These counties figured prominently in considerations of regional energy development last year.) Future sites will increase the number of forest types under study and extend the geograpinical dispersion of the sites. The characteristics of the sites selected to date are summarized in Figure 1.1.

Collection of litterfall on an experimental basis has begun in these areas, aimed at defining a suitable collector and adequate sample numbers. Traditionally, forest ecologists have used a relatively small number of large samplers for biomass estimates of litterfall. One square meter is a common size. However, statistics indicate to us that such small numbers of samplers (six is a frequently used number) can quantitatively misrepresent the forest litterfall function. Experiments are currently under way to determine the effect of sampler size on accuracy of collection in a variety of forest types. Figure 1.? shows the first series of results. obtained in a western hemlock/Douglas fir
(Tsuga heterophylla/Pseudotsuga menziesii) stand at the Neskowin Crest Naturat Area, Oregon.

Animal populations may also be profitably monitored regularly if the species gathers seasonally to nest, or rest in colonies. Gulls, terns, cormorants, auklets, herons and other birds are good candidates for long-term monitoring. Potentially valuable observations include reproductive effort and success and environmental contaminants in eggs or feces. Sites for marine bird studies to begin next year have been identified on islands in Puget Sound, the Straits of Juan de Fuca, and of $f$ the Washington Coast, as shown in Figure 1.1.

\section{Aquatic Effects}

Thi's year's effort was devoted to determining a monitoring strategy for detecting long-term effects of new energy production systems on aquatic habitats. Lakes and

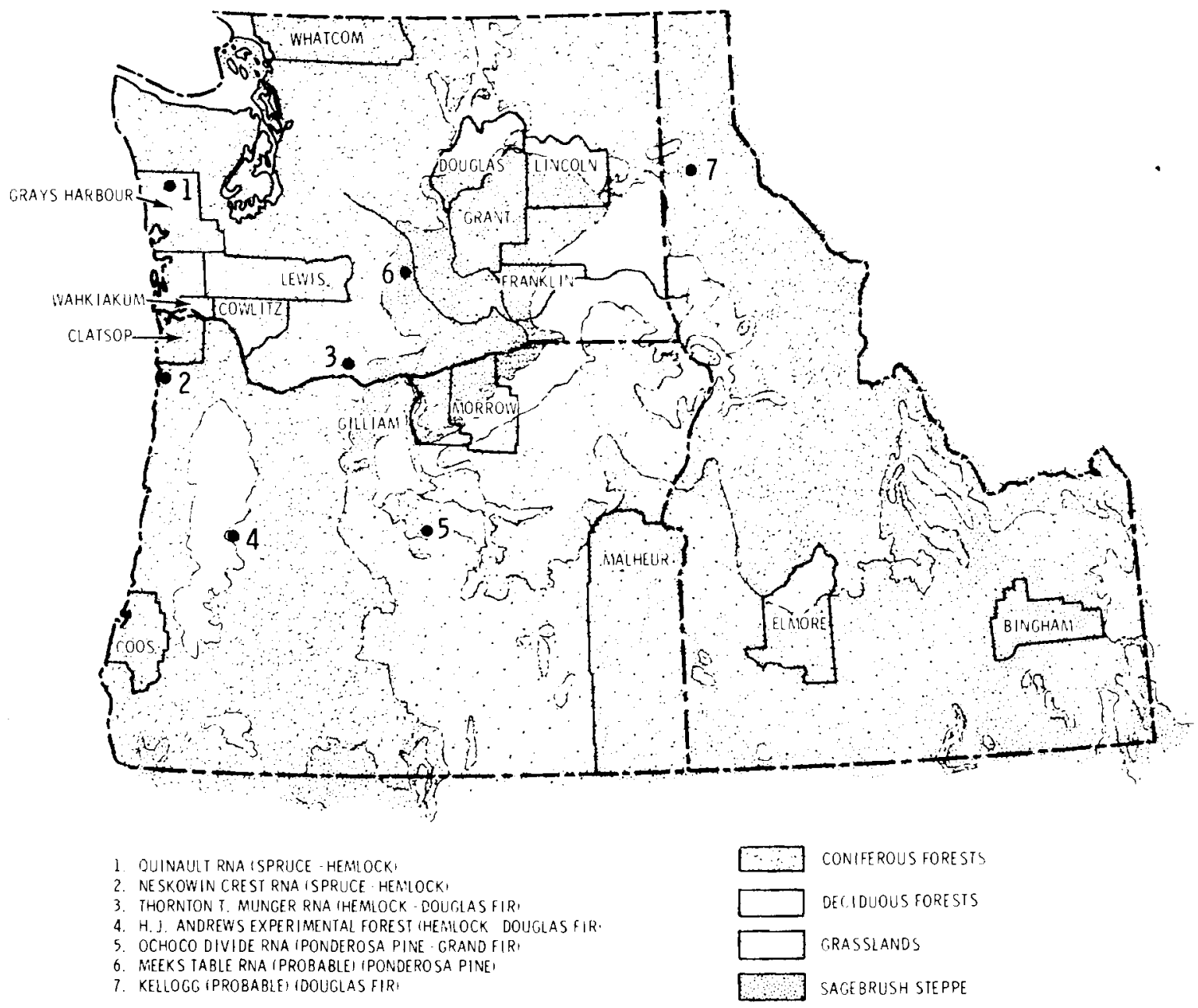

FIGURE 1.1. Research Natural Areas and Surrounding Terrain. 


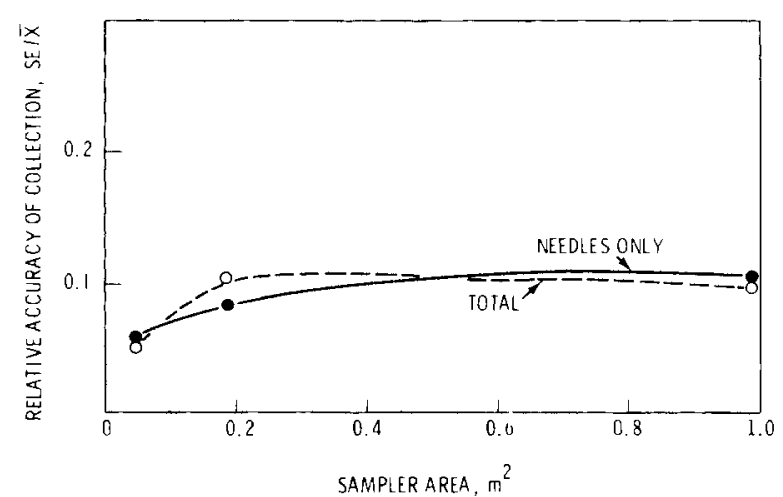

FIGURE 2.1. The Effect of Sampler Area (in $\mathrm{m}^{2}$ ) on Accuracy of Determining Mean Litterfall as Determined by the Ratio of the Standard Error (SE) to the Mean $(\bar{X})$.

other bodies of standing water differ from rivers and streams by their relative stability and in their response to environmental stresses. Because of these inherent differences, standing and flowing waters were considered separately. Four parameters ultimately were chosen for monitoring in each.

Lakes serve as collecting basins for various contaminants or pollutants. These enter directly or indirectly from the surrounding area through deposition, precipitation and runoff, making them valuable in long-term monitoring programs. The four main categories of parameters that appear to be of greatest value in long-term monitoring in lakes are 1) chemical composition of key organisms (fish, benthic invertebrates and phytoplankton), ?) chemical composition of water and sediments, 3) species composition and 4) oroductivity indices based on reproduction, biomass and survival rates of key organisms. Methods of quantifying these four parameters are well defined in the literature. Because of the relative stability of lake ecosystems, sampling or measuring the desired parameter once or twice a year should be sufficient to detect long-term trends. However, data from supporting laboratory studies may be required.

The four main categories of parameters that appear to be of greatest value in longterm monitoring of streams and rivers are 1) productivity ratios based on photosynthesis, respiration and biomass, ?) percent composition of insect functional groups,

3) detritus biomass and 4) chemical composition of fish, algae/macrophytes and invertebrates.

Sampling schedules will vary for stream monitoring. It would be desirable to collect data used in estimating productivity ratios three or four times a year (early spring, late spring after runoff, late summer and fall), but if limited to once a year, late summer is preferred. Samples to quantify percent composition of insect functional groups should be taken either in late winter, before major emergence, or fall, after egg deposition and hatching. Detritus transport and/or detritus storage should be measured in the fall and spring. Annual or semiannual sampling for chemical analysis of organisms should be sufficient in most instances. 



\title{
- Terrestrial Ecology
}

\section{- Restoration of Surface-Mined Lands}

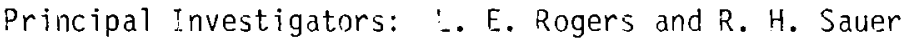

The research conducted for the Terrestrial Ecology and Restoration of Surface-Mined $L$ ands tasks is largely field-oriented. Terrestrial Ecology stidies are undertaken to determine the important plant and animal species that comprise ecosystems on the Hanford Site. These studies investigate the responses of these ecosystems to various landscape perturbations, such as shallow land burial, plowing, fire, livestock grazing, weather, and their responses to more static features of the landscape such as topography and soi1. Sampling is an iaherent part of quantitative ecology measurement; various sampling designs and strategies are tested during field studies. Long-term studies are conducted to evaluate the ecological success of self-established biotic communities on severely disturbed habitats. The behavior of potentially toxic mineral elements and those essential to plant and animal growth are being studied to establish baseline values before coal-fired power stations become operational in southcentral Washington and adjacent Oregon. Dietary habits of animals are studied to establish meaningful food webs and material transfers between ecological trophic levels.

Land restoration of surface mines involves rainfall harvest, soil placement, slope treatment and plant species selection to restore surface-mined lands to plant production without the need for irrigation. Crop plants are selected to provide food for people and/or livestock. This research is conducted on the Hanford Site, the most arid portion of Washington State (ppt $<7$ inches), and on an active mine site in Arizona.

\section{TERRESTRIAL ECOLOGY}

\section{Protection and Maintenance of the ALE Reserve}

One of the tasks of the Terrestrial Ecology Project is to prevent unwarranted trespassing and its potential damage to the vegetative cover, especially on lands believed to be near pristine conditions. This is accomplished by aerial surveillance designed to discourage trespassing, especially by offroad vehicles. The barbed-wire fence around the ALE project is regularly patrolled and repaired as needed to prevent stray livestock from grazing ALE 1 ands, damaging vegetation, and interfering with ongoing field experiments. Roadways are maintained by grading and ballasting as needed to reduce erosion and to expedite vehicular travel to remote study sites. Two air strips are marked on the ALE Reserve for emergency use.

In calendar year 1978 there were no significant intrusions of livestock or unauthorized off-road vehicle use on the ALE Reserve. Roads were maintained as needed.

\section{Climate of the ALE Reserve}

The network of 26 weather stations on the ALE Reserve was maintained. Precipitation, air temperatures and soil temperatures were recorded. The data are computer-retrievable and are available to investigators as raw data or as summaries. 
Self-Revegetation of Disturbed Ground: Longer-Term Aspects(a)

The process of self-revegetation of disturbed ground is termed ecological succession. Usually the process is initiated by the invasion of annual plants with a capacity for copious seed production and efficient seed dispersal. Over a period of years these annuals are either suppressed or replaced by perennial plants that occupy the ground for longer periods of time. In theory these perennials are the perinanent members of the site, although they can be destroyed hy sudden events such as fire, disease, or human activity. Fire and disease have relatively little impact on the physical features of the rooting substrate, but the plowing or scraping of modern machinery destroys vegetation and also stirs and mixes the surface soil layer. Plowing is not generally thought of

(a) Nevada studies were conducted with permission of the Nevada Operations Office. The cooperation of Ernie Camplell and use of the Civil Effects Tests offices Facilities are appreciated. as especially destructive because it is conducted on the best soils which are promptly seeded with economically valuable crop species. Becalse plowed ground in southeastern Washington is seldom allowed to become selfrevegetated, there is 1ittle definitive data on the rate of self-revegetation.

Probably there is no more dramatic and spectacularly destructive man-induced event to desert vegetation than that created by aboveground nuclear explosions. We investigated self-revegetation of an abandoned cultivated fiold in the semi-arid sinrub-steppe region of southcentral Washington after 30 years and that of a tract of 1 and disturbed by a nuclear explosion in the arid region of southern Nevada after 20 years.

Annual grasses, especially cheatgrass (Bromus tectorum), dominated the canopy cover of plowed ground in southcentral Nashington (Figure 1.3). The undisturbed vegetation, in contrast, was dominated by perennial grasses, especially bluebunch wheatgrass (Agropyron spicatum). More plant species were encountered in the unplowed sites than in the plowed field, but total canopy cover was greater on the plowed ground.

WASHINGTON

CATEGORY

ANNUAL GRASS

ANNUAL FORB

PERENNIAL GRASS

PERENNIAL FORB

SHRUB

\section{UNDISTURBED}

NEVADA

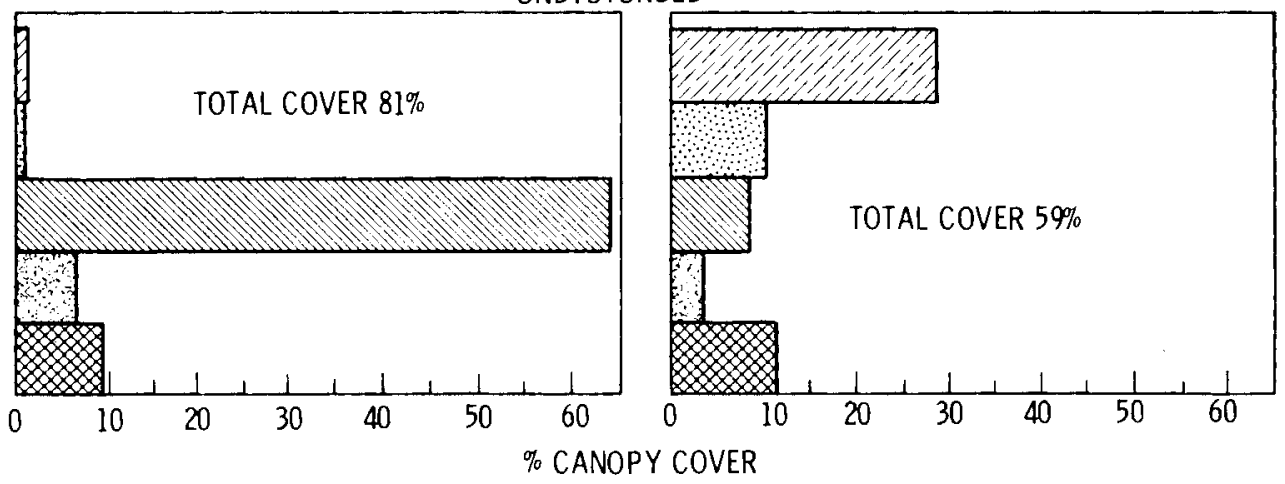

ANNUAL GRASS

ANNUAL FORB

PERENNIAL GRASS

PERENNI AL FORB

SHRUB

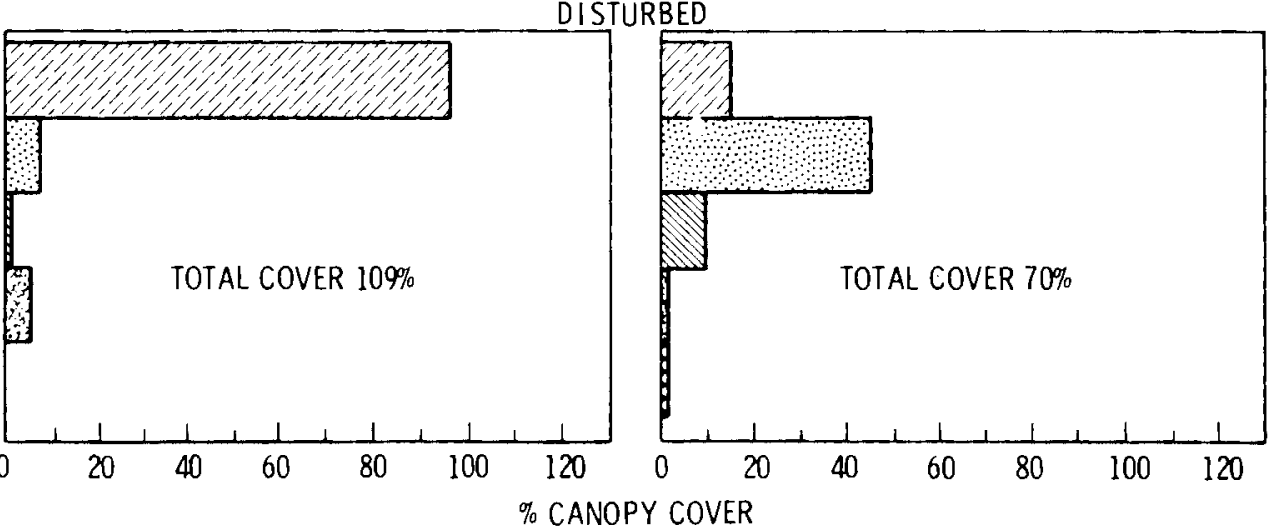

FIGURE 1.3. Comparison of Canopy Cover Provided by Self-Revegetation of Severely Disturbed Soils in the ShrubSteppe Region of Washington and Nevada. 
Annual forbs, especially filaree (Erodium cicutarium), dominated the canopy cover of severely disturbed ground at Yucca Flat, Nevada but red brome (Bromus rubens), an annual grass, also was an important contributor. The undisturbed vegetation supported about twice as many plant species as the disturbed ground. There were more species at the Nevada Site than at the Washington Site and Russian thistle (Salsola kali) was more abundant at the Nevada Site.

These data indicate that annual grasses and forbs dominate the vegetation for at least two decades following severe soil disturbance. Native shrubs and perennial grasses are slow to re-establish themselves on disturbed ground. However, total vegetative ground cover on disturbed ground exceeds that of undisturbed ground.

Self-Revegetation of Replowed Cheatgrass Communities: Short-Term Aspects

Plant productivity was studied on ground replowed after 30-year occupancy by cheatgrass. Species composition of replowed plots was very similar to that of adjacent control plots, but differences in productivity were found and attributed to changes induced by replowing.

Two long-abandoned agricultural fields were selected for study, one at an elevation of approximately $520 \mathrm{~m}$, the other about $5 \mathrm{~km}$ away at an elevation of about $305 \mathrm{~m}$. Both fields had similar soils. The air temperatures of the upper field are slightly cooler than the lower field. Annual precipitation measured over an eight-year period averaged $21.3 \mathrm{~cm}$ at the lower field and $24.8 \mathrm{~cm}$ at the upper field (Hinds and Thorp, 1977). The 1977 growing season, however, was marked by extreme drought.
Two macroplots were staked in each field, Within each macroplot, two subplots were plowed in late autumn of 1974, thereby burying almost all of the dead plants. The remainder of each macroplot was left unplowed and served as controls. Comparative data on phytomass were taken in 1976 and 1977. Phytomass estimates were made by random location of five points in each subplot. Plant material was harvested in March, April, and May, with the final harvest made on what was judged to be near peak phytomass.

The sparse plant yield on the control plots of the upper field was believed to be limited by factors other than drought because phytomass production in $1976\left(87 \mathrm{~g} / \mathrm{m}^{2}\right)$ was only slightly greater than the $83 \mathrm{~g} / \mathrm{m}^{2}$ produced in 1977, a drought year. The soil was probably deficient in nitrogen.

Surprisingly, the replowed plots in 1975 yielded almost three times more live phytomass than the control plots. This suggests that productivity was enhanced by plowing and the burying of accumulated dead plant parts, which then decomposed, making nutrients available for plant uptake. Nevertheless, the drought of 1977 had a more deleterious impact on productivity in replowed plots than on the control plots. Replowed plots produced only $35 \mathrm{~g} / \mathrm{m}^{2}$ as compared to $83 \mathrm{~g} / \mathrm{m}^{2}$ for controls. Cheatgrass (Bromus tectorum) dominated at both levels. Percent botanical composition did not differ appreciably, except for tansy mustard (Descurainia pinnata) which was noticeably higher in the lower field.

Plant yields in the lower field were much lower in 1977 than in 1975 (Table 1.1), and this is attributed to drought. The drought harmed the replowed plots more than the control plots. During 1976 the control plots

TABLE 1.1. Statistical Comparison of Phytomass on Control and Plowed Plots, May 21, 1976. The mean is derived from $0.032 \mathrm{~m}^{2}$ plots.

\begin{tabular}{|c|c|c|c|c|c|c|c|}
\hline & Location & Treatment & $\mathrm{n}$ & $\bar{x}$ & SD & $\mathrm{CV}$ & $\begin{array}{l}\text { Analysis of } \\
\text { Variance }\end{array}$ \\
\hline \multirow[t]{2}{*}{$\begin{array}{l}\text { Live } \\
\text { Phytomass }\end{array}$} & Upper Field & $\begin{array}{l}\text { Plowed } \\
\text { Control }\end{array}$ & $\begin{array}{l}20 \\
10\end{array}$ & $\begin{array}{l}9.68 \\
2.73\end{array}$ & $\begin{array}{l}4.7 \\
1.3\end{array}$ & $\begin{array}{l}0.49 \\
0.49\end{array}$ & $P(F)=0.00011$ \\
\hline & Lower Field & $\begin{array}{l}\text { Plowed } \\
\text { Control }\end{array}$ & $\begin{array}{l}20 \\
10\end{array}$ & $\begin{array}{l}5.28 \\
9.42\end{array}$ & $\begin{array}{l}0.23 \\
1.9\end{array}$ & $\begin{array}{l}0.06 \\
0.21\end{array}$ & $P(F)=3.8 \times 10^{-7}$ \\
\hline \multirow[t]{2}{*}{$\begin{array}{l}\text { Dead } \\
\text { Phytomass }\end{array}$} & Upper Field & $\begin{array}{l}\text { Plowed } \\
\text { Control }\end{array}$ & $\begin{array}{l}20 \\
10\end{array}$ & $\begin{array}{c}1.27 \\
12.6\end{array}$ & $\begin{array}{l}1.9 \\
5.8\end{array}$ & $\begin{array}{l}1.47 \\
0.46\end{array}$ & $P(F)=8.2 \times 10^{-9}$ \\
\hline & Lower Field & $\begin{array}{l}\text { Plowed } \\
\text { Control }\end{array}$ & $\begin{array}{l}20 \\
10\end{array}$ & $\begin{array}{l}1.40 \\
11.5\end{array}$ & $\begin{array}{l}1.5 \\
1.7\end{array}$ & $\begin{array}{l}1.06 \\
0.15\end{array}$ & $P(F)=0.00$ \\
\hline
\end{tabular}


were almost twice as productive as the plowed plots. These findings suggest that the dead plant material (mulch) is probably more important as a soil water conservation measure than as a nutrient source.

Statistical comparisons of mean phytomass values between replowed and control plots are presented in Table 1.1. An analysis of variance indicates that the differences between means are highly significant between live and dead phytomass values on the control and the replowed plots.

\section{Microtopography and the Vegetative Recovery of Steep Slopes}

Although the plants that comprise steppe vegetation provide a more or less uniformappearing ground cover, the amount of cover and its species composition varies from place to place according to the physical and chemical properties of the rooting substrate and to variations in microclimate as influenced by macro- and microtopographic features of the 1 and. In field investigations it is often not feasible to separate substrate variables and those variables affecting plant growth caused by slope exposure. Nor is it al'ways possible to separate those ecological factors concerning inter- and intraspecific competition as related to plant community development.

Our earlier studies of species composition and canopy cover on contrasting slopes showed considerable difference in (natural) rooting substrate (Sauer, R. H., and Rickard, W. H., accepted, Vegetation of steep slopes in the shrub-steppe region of southcentral Washington, Northwest Science). The present investigation examines these and other appropriate parameters using artificial earth mounds. Other work has indicated that microclimate, rather than soil variables, controlled phenology and plant productivity (Hinds, 1975).

Cheatgrass (Bromus tectorum) seeds were hand-planted on the slopes in early autumn. The ground was unattended until the 1977-1978 growing season when this investigation was undertaken. New plant growth was initiated with the onset of autumn rains. By midDecember 1977 aboveground live phytomass averaged 101 and $7.5 \mathrm{~g} / \mathrm{m}^{2}$ for the north and south-facing slopes respectively. Aboveground growth was slowed during the winter months but resumed when temperatures warmed in April. Plants attained maturity on the south-facing slope in April but maturation was delayed until mid-May on the north-facing slope.

At the end of the spring growing season, plants on the north-facing slope produced $830 \mathrm{~g} / \mathrm{m}^{2}$ dry wt as compared to on 1 y $163 \mathrm{~g} / \mathrm{m}^{2}$ for the south-facing slope. Almost all the phytomass produced on the north-facing slope was cheatgrass. Tumble mustard (Sisymbrium altissimum) and cheatgrass shared dominance on the south-facing slope.

The larger yield on the north-facing slope places its net primary production in the midrange of the world's natural ecosystems and much higher than the yields expected of arid 1 and (desert) ecosystems. The north-facing slope cheatgrass yield was about 10 times greater than that of climax sagebrushcheatgrass (Artemisia tridentata-Bromus tectorum) communities and about twice that of level land cheatgrass swards during peak production years. In contrast the southfacing slope phytomass was more representative of arid land productivity.

Dead plant phytomass (1itter) was high in winter months and declined as the growing season progressed (Table 1.?). Sampling variability was high partly because the dead plant material was unevenly distributed over the slopes. Dead plants and plant parts tended to accumulate in irregularly occurring microdepressions on the slopes. Nevertheless, dead plants tended to disappear; this is attributed to accelerated decomposition rates during the spring months when temperatures and soil moisture are most favorable. On the average there was more accumulated dead plant material on the nort? slope than on the south slope.

Since its inadvertent introduction to North America from Europe, cheatgrass continues to strengthen its position on southcentral Washington rangelands. It apparently has little competition from the native plants on disturbed ground. Although cheatgrass is held in low esteem by livestock raisers, it can provide a self-sustaining ground cover that retards soil erosion. In arid regions, where 1 and is not intended for livestock grazing, cheatgrass would seem to be a quick and effective way to establish a selfsustaining plant cover capable of resisting

TABLE 1.2. Dead Phytomass $\left(\mathrm{g} / \mathrm{m}^{2} \pm \mathrm{SE}\right.$ dry wt) on North and South Slopes of an Artificial Earth Mound.

\begin{tabular}{lll} 
Date & North & South \\
\cline { 2 - 3 } Dec 15 & $449 \pm 80$ & $308 \pm 52$ \\
Feb 10 & $443 \pm 84$ & $357 \pm 50$ \\
Feb 22 & $244 \pm 77$ & $335 \pm 84$ \\
Mar 24 & $243 \pm 45$ & $114 \pm 43$ \\
Apr 18 & $216 \pm 50$ & $182 \pm 82$ \\
May 17 & $124 \pm 52$ & \\
\hline
\end{tabular}


soil erosion even on steep slopes. Cheatgrass is more acceptable in the time scale of ecological secondary succession if it is regarded as an early invader of disturbed habitats rather than as a noxious weed to be eradicated and replaced with those native species that do not appear to use water, energy and nutrients as effectively.

Leaffall in Desert Shrubs as a Method for Long-Term Monitoring of Ecological Trends

Long-term environmental monitoring studies are usually designed to detect changes in biological performances in relation to specific man-induced changes in the outdoor enviroment. Apart froin construction activities, some environmental damages are subtle, occur slowly over time, and can extend over extensive acreages and may even be speciesspecific. Examples of the latter kind of impacts are those caused by chronic industrial air pollution. Impacts may be direct and observed as visible leaf damage to trees or decreased plant productivity (crop plants), or indirect impacts may be seen through climatic changes by increased $\mathrm{CO}_{2}$ content of the air, or by acidified precipitation altering soil pH and plant uptake of essential mineral nutrients.

Air pollutants such as mentioned above have not been of as much concern in the arid West as in more populous regions of the United States and Europe, because air polluting industries are scarce. Steppe shrubs also are not of great economic value as are trees and crop plants, but they can be used as monitoring organisms by systematically collecting leaffall and chemically analyzing the collected leaves. In this way biological buildups of trace elements and other fine particle pollutants derived from a variety of industrial sources might be detected early and extrapolations made concerning long-term mineral nutrient changes in shrub leaves.

Advantages of the leaffall monitoring method are that it is biologically nondestructive and it can be monitored monthly over decades. The leaffall approach is being tested here and studied for suitability as an indicator in the monitoring of long-term ecological trends. It has not been widely used for desert sirub-steppe terrain, however (Bray and Gorham, 1954).

Shrub-steppe vegetation in Washington is characteristically comprised of an overstory layer of small, widely-spaced, microphyllous shrubs and an understory layer made up mostly of grasses. By far the most abundant and widespread shrub is big sagebrush (Artemisia tridentata). Sagebrush is an autumn-blooming species. Bitterbrush (Purshia tridentata), hopsage (Grayia spinosa), and greasewood (Sarcobatus vermiculatus) are spring-blooming species. It appears that sagebrush's autumnal flowering and its maintenance of leaves yoarround has some scological advantages. New leaves appear in March and a full complement is in place in April and May, the months most favorable for plant growth. Many but not all leaves are shed in summer, thereby reducing water losses by reducing leaf surface area. The monthly pattern of leaffall suggests that there is adaptive advantage in these two phenomena.

For this study, special litterfall collectors were placed beneath the canopy spread of four bushes of each species. Sagebrush study bushes were located at different elevations. The collectors were emptied of leaf material each month and returned to their original places. The contents were handsorted to exclude twigs and other debris, oven-dried, and weighed.

Only $3 \mathrm{~cm}$ precipitation fell between october 1975 and october 1977. This drought was reflected in minimal leaffall accumulations at all study sites except a high elevation sagebrush site. The 1975 growing season was wetter $(9.2 \mathrm{~cm}$ between 0ctober 1375 and April 1975), resulting in relatively large litterfall collections later in the year. Hopsage was severely affected by the 1977 drought (Figure 1.4). It produced no leaves, which resulted in no summer leaffall. In 1975, hopsage produced leaves in March and abscised leaves appeared in the collectors in May, June, July and August. Thereafter the plants were bare. Most of the leaves dropped in June and July.

Greasewood was also severely affected by the 1977 drought even though it was believed that greasewood sirubs were capable of tapping a permanent supply of groundwater (Harr and Price, 1972). Total cumulative leaffall was much less in 1977 than in 1976. In 1977 leaffall lasted the same duration as it had in 1975, but there was no leaffall peak in November as observed in 1975 (Figure 1.4). only one-fourth of the cumulative hitterbrush leaffall was collected in 1977 as compared to 1975. Nevertheless the monthiy distributional pattern of leaffall was similar during both years (Figure 1.4).

The low elevation sagebrush plants produced only about one-third the leaffall in 1977 that they did in 1975 and the monthly pattern of leaffall was also different (Figure 1.5). There were no June, July and August peaks as in 1975. The high elevation sagebrush plants were apparently not affected by the 1977 drought. The average cumulative 1 itterfall was slightly greater in 1977 than in 1976 but the monthly pattern of leaffall was similar in both years.

On the ALE Reserve soil water penetration depth varies from year to year depending upon amount of rainfall and soil type, but in most 


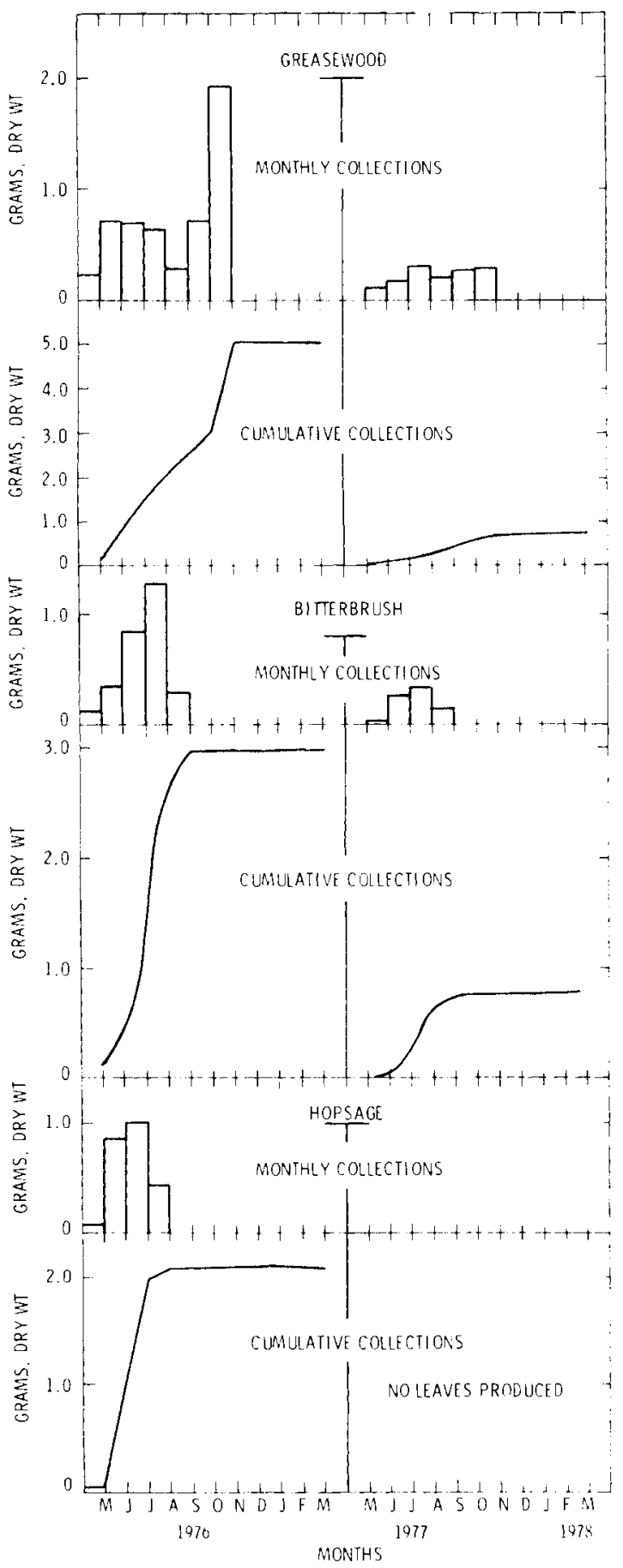

FIGURE 1.4. Leaf Litter Collections at Monthly Intervais, May 1976 to March 1978, for Greasewood, Bitterbrush and Hopsage (g dry wt/collection device).

years soil water penetration is restricted to the upper meter of soil profile. Soil water normally reaches peak accretion values in February. Soil water steadily declines in the upper meter of soil, and herbaceous plants wither in June on its depletion (Sauer and Uresk, 1976). Only one shrub species appears to be closely synchronized in leaffall to this seasonal soil water pattern. This is hopsage. Bitterbrush has a leaffall pattern like hopsage, except that

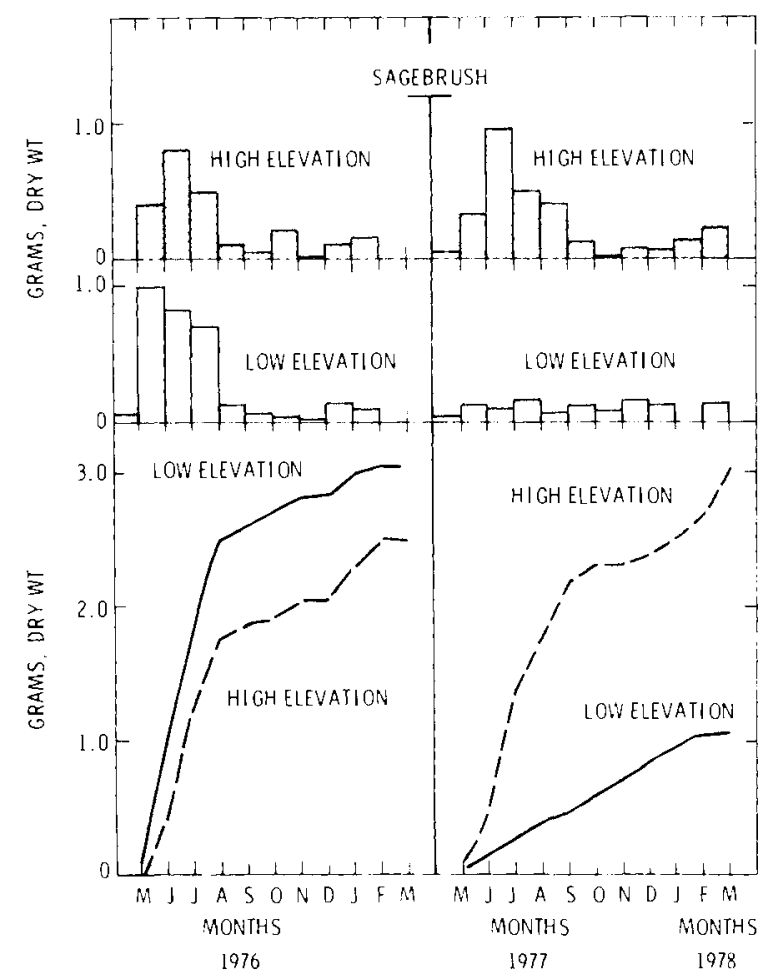

FIGURE 1.5. Leaf Litter Collections at Monthly Intervals, May 1976 to March 1978, for Sagebrush Shrubs Located at High and Low Elevations (g dry wt/collection device).

new leaves emerge later in the spring and leaves persist longer into the summer. Unlike hopsage, bitterbrush is never entirely without leaves. It grows on the sandiest soils. These soils probably permit deeper soil water penetration, which would account for the observed delay in leaffall in bitterbrush as compared to hopsage.

Greasewood and hopsage grow side by side in the same habitat, yet the monthly pattern of leaffall is markedly different. Greasewood branches usually retain their leaves throughout the hot, dry summer months and then shed the ir leaves with the onset of winter. It was expected that greasewood plants would be unaffected by drought because of their capability to tap groundwater supplies (Harr and Price 1972). Prolonged drought might have affected leaf production if groundwater levels were lowered beyond the reach of the established root systems, or if roots were not able to move enough water to maintain leaf turgor and photosynthesis. Studies will be continued to determine if greasewood shrubs return to normal production during years of normal precipitation. Special attention would be given to the monthly periodicity of leaffall as well as to comparing total amounts of leaffall between years. Samples will be submitted for chemical analyses of those ecologically important minerals likely to be present in coal combustion stock effluents of a coal-fired power plant located nearby in Boardman, Oregon. 


\section{Phenology Studies}

Plant phenology studies on the ALE Reserve are continuing. Observations are made weekly on the timing of the onset of various plant growth phases. A continuous record of microclimatologic data measisring soil and air temperature, insolation, precipitation and soil water potential is also maintained. The plant phases recorded are the dates of growth initiation, floral bud initiation, flower opening, ripening of fruit, and end of growth. This study has continued since 1973. The five years of data permit an analysis of the relationship between plant development and microclimate.

In the past year, the most notable observation was that the severe drought of the 1977 growing season apparently threw the expected progression of plant development off schedule. Some species, in particular longleaved phlox (Phlox longifolia), continued to bloom throughout the winter, an unusual observation for this normally spring-blooming species. This response to a suppression of spring growth will be further studied through analyses of past collections of plant phenology and microclimate data. It is expected that such analyses will increase the understanding of weather on seasonal progression of plant development and ecosystem processes in genera 1 .

Astragalus columbianus: An Endangered Plant Species on the Hanford Site

Astragalus columbianus is listed as "rare, endangered and probably extinct." It is known from only two specimens, one in fruit only and the other in flower only. The fruiting specimen, the typus, was collected by Brandgee and Tweedy in 1883 in what was then the Walla Walla region of the Washington Territory and was identified as Astragalus casei. The flowering specimen was collected by H. St. John in 1922 above Priest Rapids, Yakima County, Washington and was identified as A. reventus. R. C. Barneby studied these two specimens and classified them as a new and different species, A. columbianus. This species is probably designated as "rare, endangered and probably extinct" because so few specimens had been found and because so much time had elapsed since its last collection in 1922.

The Priest Rapids region of the Columbia River immediately north of the Hanford Site is an area of fast-flowing water and large rocks. A. columbianus was found growing on benchlands between the high basaltic cliffs and the river along the west bank. For the most part the population of $A$. columbianus is on Federal land outside the boundaries of the Hanford Site. Here the typical shrub-steppe vegetation consists, in part, of big sagebrush (Artemisia tridentata), rabbitbrush (Chrysothamnus nauseosus), bitterbrush (Purshia tridentata), long-leaved phlox (Phlox Tongifolia), large-flowered desert parsley (Lomatium macrocarpum), cheatgrass (Bromus tectorum), woolly-pod milkvetch (Astragalus purshii), stalked-pod milkvetch (A. speirocarpus), needle-and-thread grass (Stipa comata), and hawk's beard (Crepis atrabarba).

The new collections match Barneby's description in all details except the position of the inflorescence, which he described as the first to third nodes. However, the single extant specinen with flowers shows some evidence of grazing damage which could have altered the position of the inflorescence to a point lower on the stem. Only a few specimens were collected to avoid further reducing the size of the population.

\section{Bats of the ALE Reserve}

Bats have seldom been collected on the Hanford Site and no previous attempts have been made to examine their temporal and spatial distribution or habitat preferences. In July of 1978 a study was undertaken to collect bats inhabiting riparian habitats (Snively Gulch, Rattlesnake Springs) on the ALE Reserve. Six mist nets were placed over or adjacent to the stream in Snively Gulch and two were situated over or near the stream at Rattlesnake Springs. Three species of bats were captured. The western pipistrelle (Pipistrellus hesperus) was the most frequently captured (Table 1.3) and was also observed flying about during twilight hours. None of the location or date records for the species captured were unusual for Washington. Specimens were mounted and kept in the collection at ALE Headquarters. These specimens provide authentic records of bats on the Hanford Site.

TABLE 1.3. Findings of Bats on the ALE Reserve.

\begin{tabular}{|c|c|c|c|}
\hline Species & $\begin{array}{l}\text { Dates and } \\
\text { Number } \\
\text { Captured } \\
\text { or Sighted }\end{array}$ & Location & Sex \\
\hline $\begin{array}{l}\text { Western } \\
\text { Pipistrelle } \\
\text { (Pipistrellus } \\
\text { hesperus) }\end{array}$ & $\begin{array}{l}\text { July } 7(1) \\
\text { July } 27(1) \\
\text { August } 10(1) \\
\text { August } 30(1)\end{array}$ & $\begin{array}{l}\text { Snively Gulch } \\
\text { Snively Gulch } \\
\text { Snively Gulch and } \\
\text { Rattlesnake Springs } \\
\text { Snively Gulch and } \\
\text { Rattlesnake Springs }\end{array}$ & $\begin{array}{l}d^{x} \\
\sigma^{x} \\
d^{x}\end{array}$ \\
\hline $\begin{array}{l}\text { Silvery-haired } \\
\text { Bat (Lasionycteris } \\
\text { noctivagans) }\end{array}$ & $\begin{array}{l}\text { July } 7 \text { (1) } \\
\text { August } 30(1)\end{array}$ & $\begin{array}{l}\text { Snively Gulch } \\
\text { Rattlesnake Springs }\end{array}$ & $\begin{array}{l}0^{x} \\
\delta^{x}\end{array}$ \\
\hline $\begin{array}{l}\text { Hoary Bat } \\
\text { (Lasiurus } \\
\text { cinereus) }\end{array}$ & August 30 (1) & Snively Gulch & $d$ \\
\hline
\end{tabular}


Bald Eagles Wintering on the Hanford Site, 1977

Field notes have been kept of bald eagle (Haliaeetus leucocephalus) wintering densities along the Columbia River on the Hanford site from 1351 through 1959 and 1974 through 1977. The population apparently increased from five birds in the 1950's to over 15 birds in the 1970's (Figure 1.5). Eagles generally arrive during mid-November witi a period of peak abundance occurring in late November through early February and begin to depart in mid-Fehruary. All have usually disappeared by early March.

The bald eagle apparently is attracted to the Hanford Site by spawned-out, fish carcasses in the Columbia Qiver that wash ashore after the autumn spawning period. The bald eagle is important to the Hanford Site because it is regarded as a threatened species in the state of Washington.

\section{A Comparison of Two Gull Nest Census} Techniques

In large colonies of ground-nesting birds, a total nest count is difficult to obtain. Time and cost required for such a census is usually prohibitive and often may be too disturbing to the nesting birds. Gull nesting censuses are important to the Hanford Site because islands in the Columbia River provide nesting habitats for several thous and pairs of nesting gulls. In an effort to reduce censusing time without sacrificing accuracy, two census techniques on nesting ring-billed gulls (Larus delawarensis) and California gulls (Larus californicus ) were tried. The two techniques are referred to as 1) the line transect (100 $\mathrm{m}^{2}$ area) and ?) the circular plot $\left(100 \mathrm{~m}^{2}\right)$.

In the line transect method, a $50 \mathrm{~m}$ tape is laid on the ground in a specified habitat. An observer then walis the line counting all nests within a $1 \pi$ strip on each side of the tape. A meter stick is carried along to assure accuracy. In the circular plot technique, plots are selected at random in specified habitats. A piece of cord $5.54 \mathrm{~m}$ long is used to circumscribe an area around a center pivot point. One observer holds the center point while the second walks the circumference of the circle counting all nests within the circular area. The circular plots were selected by walking 30 paces in a random direction and then placing the pivot point of the radius at this spot.

The circular plot method proved to be quicker than the transect method yet it still covered a $100 \mathrm{~m}^{2}$ area. The circular plot method was also suited to estimating nest densities in different kinds of vegetative cover. The line transect often ran through several kinds of vegetation and could not be used for distinguishing variations in nest. ing densities related to vegetational differences.

In comparing density estimates derived from the two different census methods (Table 1.4), we found that the line transect method yielded a higher density estimate for california gulls than the circular plot. However, ring-billed gull nest density estimates using the tivo techniques were nearly identical. The differences noted in the

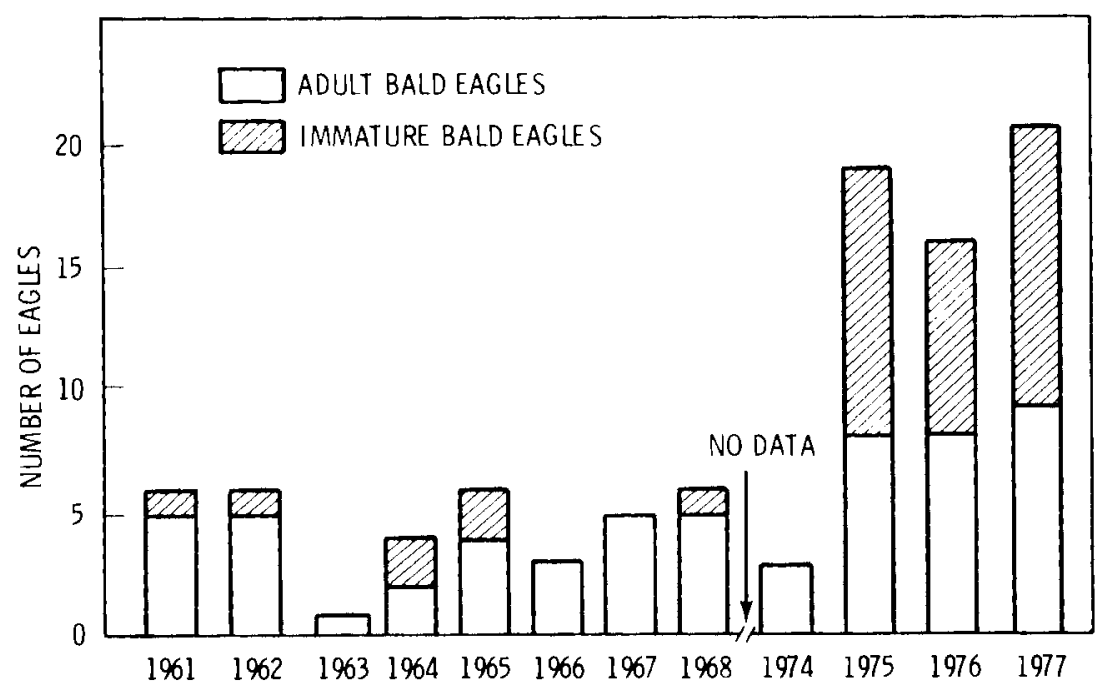

FIGURE 1.6. Numbers of Bald Eagles Observed on the Hanford Site During the Years $1967-68$ and $1974-77$. 
Salifornia gull nest density estimates are probably a reflection of the small sample size using the line transect and may also be the result of the possible inclusion of some ring-bill territories. Since the line transect is laid out along a $50 \mathrm{~m}$ tape, it was not always possible to keep completely within California gull nesting areas. The lack of flexibility in selecting the $100 \mathrm{~m}^{2}$ sample plots with the line transect method is certainly another shortcoming of this census technique. Field studies in 1979 will further test these two techniques and others in order to find one best suited for estimating nesting densities of colonial nesting gulis and other birds.

TABLE 1.4. Average Density of Gull Nests as Determined by Two Different Census Types.

\begin{tabular}{lcc} 
& \multicolumn{2}{c}{ Census Type } \\
Species & $\begin{array}{c}\text { Line Transect, } \\
\mathrm{n}=5\end{array}$ & $\begin{array}{c}\text { Circular Plot, } \\
\mathrm{n}=10\end{array}$ \\
\cline { 1 - 1 } $\begin{array}{l}\text { Ring-billed Gull } \\
\text { California Gull }\end{array}$ & $\begin{array}{c}19.4 / 100 \mathrm{~m}^{2} \\
20.8 / 100 \mathrm{~m}^{2}\end{array}$ & \\
$14.0 / 100 \mathrm{~m}^{2}$ & $6.8 / 100 \mathrm{~m}^{2}$
\end{tabular}

Abundance of Large and Medium-Sized Animals on the Hanford Site

The abundance of large and medium-sized animals on the Hanford Site is of special concern since their food habits, behavior and density has a substantial effect on ecosystem dynamics. In addition, deer, eik, rabbits and coyotes are of particular interest to the general public. The presence of smail and medium-sized animals was documented by censusing thirty transects on the Hanford Site having dimensions of $1.5 \mathrm{~km}$ by $75 \mathrm{~m}$. The census included ail major habitat types. It was conducted at night using a 200,000 candle power spotlight while driving at speeds ranging between 16 and $32 \mathrm{~km} / \mathrm{hr}$. In June 1978 the census was taken for three consecutive nights. The number of sightings of each species over the three-night survey was compared to results in a similar survey taken in 1977. The three species encountered during the 1978 survey were Rocky Mountain mule deer (0decoileus hemionus), coyotes (Canis latrans), and bTack-tailed hares (Lepus californicus). The number of black-tailed hares was Tower in June of 1978 (31) than in June of 1977 (47). Coyote sightings in the transects were the same during both study years with two coyotes observed during each study period. The number of deer (eight) sighted in 1978 also was similar to that found in the 1977 survey (six).
Consumer Food Habits, Beetles and Ground Squirrets

Diet characterization of major consumers is essential since consumption serves as a control point for all materials entering the transfer patiways. Food habit analysis is a useful tool in understanding how particular consumer populations partition the available food suppiy. Tt aiso serves as a starting point for documenting how foodstuffs and associated materials flow through the ecosystem. Food habit analysis includes inquiry into 1) food materials present, ?) consumers present, and 3) food preferences for speci$f i c$ consumers and dietary similarity of consumers occurring in the same community.

\section{Diet Similarity of Darkling Beetles} Tenebrionidae)

The diet composition of individual dark$1 \mathrm{ing}$ beeties, their abundance, and the length of their activity periods together determine much of the beeties' impact within natural communities. Measurement of diet simitarities permits grouping of beetle cohorts having the same feeding patterns, thereby simplifying management of controlled areas and aiding in our understanding of ecosystem functioning.

A similarity matrix is shown in Table 1.5 . High indices of diet similarity indicate a high degree of dietary overlap. Similarity analysis for Eleodes nigrina and E. hispilabris resulted in a calculated value of 58.0 , which is interpreted as meaning that these two beetles select basicaliy the same food items. The low similarity values for $E$. humeral is and ali other species mean that E. humeraTis is unique in its food selection.

The means of similarity indices are shown in the last column $(x)$ of Table 1.5. This permits a ranking of those species with a high degree of overlap (high means) and those with low means, indicating little dietary overlap with other darkling beetle species. Application of an analysis of variance test revealed the mean values to be significantly different $(\alpha=0.05)$. A Student-Neuman-KueTs multiple range test was then used to identify the values responsible for the statistical significance in mean values. Similar letters indicate those mean values that are not significantiy different from each other. This is interpreted to mean that E. nigrina, E. novoverrucula, E. granulata, PhiTolithus densicolitis, and E. hispilabris select the same food piant species, but as a group are different from all other beeties. The only species that have completely unique diets are E. humeralis, E. obscura, and Blapstinus sp. 
TABLE 1.5. Similarity Indices for Diets of Darkling Beetles.

\begin{tabular}{|c|c|c|c|c|c|c|c|c|c|c|c|c|c|c|}
\hline Species & (1) & (2) & (3) & (4) & (5) & $(6)$ & (7) & $(8)$ & (9) & (10) & (11) & $(12)$ & (13) & $\bar{X}^{(a)}$ \\
\hline Eleodes nigrina (1) & & . 52.4 & 57.0 & 63.0 & 68.0 & 51.7 & 48.8 & 51.4 & 39.7 & 40.8 & 31.3 & 27.6 & 24.2 & $46.3 \mathrm{~A}$ \\
\hline Eleodes novoverrucula (2) & & & 60.1 & 49.9 & 50.4 & 54.9 & 42.7 & 37.0 & 39.9 & 64.0 & 38.7 & 28.8 & 29.4 & $45.7 \mathrm{~A}$ \\
\hline Eleodes granulata (3) & & & & 61.0 & 59.6 & 39.9 & 49.3 & 60.0 & 32.5 & 38.5 & 28.7 & 41.4 & 10.2 & $44.9 \mathrm{AB}$ \\
\hline Philolithus densicollis (4) & & & & & 55.8 & 48.3 & 42.8 & 57.9 & 39.9 & 38.2 & 26.6 & 19.7 & 18.6 & $43.5 \mathrm{AB}$ \\
\hline Eleodes hispilabris (5) & & & & & & 44.7 & 45.4 & 40.3 & 38.0 & 33.2 & 33.9 & 24.9 & 14.2 & $42.4 \mathrm{ABC}$ \\
\hline Coniontis setosa (6) & & & & & & & 41.6 & 56.4 & 38.2 & 35.2 & 35.1 & 23.7 & 25.3 & $41.3 \mathrm{BCD}$ \\
\hline Conisattus nelsoni (7) & & & & & & & & 35.8 & 51.2 & 26.1 & 41.6 & 31.7 & 20.2 & $39.8 \mathrm{CD}$ \\
\hline Stenomorpha puncticollis (8) & & & & & & & & & 21.6 & 25.9 & 30.0 & 35.5 & 10.3 & $38.5 \mathrm{D}$ \\
\hline Eusattus muricatus (9) & & & & & & & & & & 23.4 & 28.2 & 16.1 & 58.2 & $35.6 \mathrm{E}$ \\
\hline Oxygonodera hispidula (10) & & & & & & & & & & & 29.9 & 20.1 & 25.5 & $33.4 \mathrm{E}$ \\
\hline Blapstinus spp. (11) & & & & & & & & & & & & 18.3 & 14.4 & $29.7 \mathrm{~F}$ \\
\hline Eleodes obscura (12) & & & & & & & & & & & & & 9.8 & $24.8 \mathrm{G}$ \\
\hline Eleodes humeralis (13) & & & & & & & & & & & & & & $21.7 \mathrm{H}$ \\
\hline
\end{tabular}

(a) Means followed by similar letters are not significantly different.

\section{Ground Squirrel Food Habits}

Fecal pellets from $7 ?$ individual ground squirrels (Spermophilus townsendi i) were examined microscopicaliy and a total of 15 plant taxa identified. The most commonly occurring food items in their diets (Table 1.5) were a bluegrass (probably Sandberg's bluegrass (Poa sandbergii, 28\%), and two forbs, tansy mustard (Descurainia pinnata, 24\%) and lupine (Lupinus TaxifTorus, 18\%). The habitat frequency of these three heavily for aged species was $15 \%, 14 \%$ and $1 \%$ respectively, indicating that the ground squirrels are probably actively searching them out. The abundance of bluebunch wheatgrass (Agropyron spicatum, 14\%), six weeks fescue (Festuca octofTora, $9 \%$ ) and lomatium (Lomatium macrocarpum, 10\%) in the habitat had associated consumption frequencies of $<1 \%$. This indicates that these plant species are being selected against (Table 1.6). Phlox occurred with a field frequency of $2 \%$ and diet frequency of $5 \%$, indicating that it may be a preferred food item. The low frequency of ingestion (1\%) of big sagebrush (Artemisia tridentata) approximates its occurrence in the field $(3 \%)$ indicating that it is neither selected nor avoided as food.

Winterfat (Eurotia lanta) is indicated as occurring in the diet with a frequency of $<7 \%$. Any value of $<1 \%$ is interpreted here as an indication, but not positive evidence, of its presence. Some miscellaneous food items in the diet included insects $(12 \%)$, seeds $(5 \%)$ and pollen $(<7 \%)$.
TABLE 1.6. Relative Frequency of Plant Species in the Habitat and Diet of Townsend Ground Squirrels.

\begin{tabular}{|c|c|c|}
\hline & $\begin{array}{c}\text { Habitat } \\
\text { Frequency, \% } \\
\end{array}$ & $\begin{array}{c}\text { Diet } \\
\text { Frequency, \% }\end{array}$ \\
\hline \multicolumn{3}{|l|}{ Grasses } \\
\hline Agropyron spicatum & 14 & $<1$ \\
\hline Bromus tectorum & 3 & 0 \\
\hline Festuca octoflora & 9 & 0 \\
\hline Poa sp. & 15 & 28 \\
\hline Stipa thurberiana & 1 & $\leq 1$ \\
\hline Total & 42 & 28 \\
\hline \multicolumn{3}{|l|}{ Forbs } \\
\hline Amsinckia lycopsoides & $<1$ & 0 \\
\hline Antennaria dimorpha & 2 & $<1$ \\
\hline Astragalus purshii & $<1$ & 2 \\
\hline Calochortus macrocarpus & 7 & 0 \\
\hline Chenopodium album & 0 & $<1$ \\
\hline Crepis atrabarba & 6 & 0 \\
\hline Descurainia pinnata & 14 & 24 \\
\hline Draba verna & 2 & 0 \\
\hline Erigeron filifolius & 5 & 0 \\
\hline Eriophyllum lanatum & 0 & $<1$ \\
\hline Holosteum umbellatum & $<1$ & 0 \\
\hline Lappula redowskii & $<1$ & 0 \\
\hline Lepidium perfoliatum & 0 & 2 \\
\hline Lomatium macrocarpum & 10 & 0 \\
\hline Lupinus laxiflorus & 1 & 18 \\
\hline Microsteris gracilis & $<1$ & 0 \\
\hline Plantago purshii & 2 & 0 \\
\hline Salsola kali & 0 & $<1$ \\
\hline Sisymbrium ahtissimum & 2 & 0 \\
\hline Townsendia florifer & 0 & 2 \\
\hline Total & 51 & 48 \\
\hline \multicolumn{3}{|l|}{ Shrubs, and Half-Shrubs } \\
\hline Artemesia tridentata & 3 & 1 \\
\hline Eurotia lanata & 0 & 1 \\
\hline Phlox longifolia & 2 & 5 \\
\hline Total & 5 & 7 \\
\hline
\end{tabular}




\section{RESTORATION OF SURFACE-MINED LANDS}

Slope Treatment, Water Harvest and Crop Yields, 1978

The arid regions of the U.S. are likely to experience more surface mining for coal as demands for electric power increase. The existing vegetation in these arid regions is sparse but valuable as livestock and wildife forage, and as a soil binder to reduce erosion. During surface mining, the substrate and soil are fully disorganized so that immediate re-establishment of the original vegetation is not likely. Instead of the more desirable native species, weedy alien species often invade the disturbed 1 and, decreasing its economic and aesthetic value.

A conventional approach to restoring mined 1 and involves regrading the spoil into gentle slopes and applying seeds, fertilizer and irrigation water to re-establish a vegetative cover. The results of the conventional approach are frequently regarded as successful, but depend upon the availability of irrigation water. However, water is often scarce in arid regions, particularly over extended periods of time.

This program investigates and demonstrates an alternative approach to land restoration that does not depend on irrigation water. This approach aiso requires less regrading of the spoil material, thus conserving fuel, and allows more economically valuable crops to be grown. The strategy is to use the slopes of the partially graded spoil lands to intercept and direct precipitation to a strip of topsoil between the spoil banks where the crops are planted. Thus, part of the area (the spoil slopes) is devoid of vegetation and is used for rainfall collection only, and the remainder is used for crop cultivation.

This approach is currently being demonstrated on the arid Hanford Site. Coarse alluvium has been graded into simulated spoil banks $100 \mathrm{~m}$ long and $18 \mathrm{~m}$ wide. Topsoil strips $3 \mathrm{~m}$ wide lie between the slopes. Two agricultural crops have been planted: grapes (four varieties) for their high economic value and deep roots, and wheat (Nugaines, a winter wheat) because it is extensively planted in this region. Several runoff treatments have been applied in an attempt to identify an effective means of maximizing runoff water for the crops. These treatments are paraffin wax, rubber sheeting, and rubberized asphalt. There is also an untreated control area without adjacent slopes. The microclimate features that are being monitored are soil water content and temperature, air temperature at canopy height $(30 \mathrm{~m})$ and at $1 \mathrm{~m}$, precipitation, insolation, and wind speed and direction. To consider the effect of slope aspect, some of the valleys are oriented NS and others Tie in an EW direction.

A11 slope treatments were tested during the 1978 season. Table 1.7 shows production of wheat in each growing area. (Grape productivity has not been measured; the grapes are still too young to bear fruit.) The valley with the slopes covered with rubber sheeting, the maximum runoff treatment, had the highest productivity. The NS valleys produced more wheat than the EW valleys. This may be because high-velocity winds funneled through the valleys in autumn when wheat was germinating, removing several centimeters of soil and uncovering the emerging wheat. As a consequence, many of the young wheat plants died and were 1 ater replaced by Russian thistle, an undesirable weed.

TABLE 1.7. Wheat Production, 1978.

\begin{tabular}{lr} 
Treatment & $\begin{array}{c}\text { Bushels of Grain/ } \\
\text { ac }\end{array}$ \\
\hline NS Valleys & \\
Rubber Sheeting & 22.1 \\
Untreated Slopes & 8.2 \\
Paraffin & 16.8 \\
No Adjacent Slopes & 4.4 \\
EW Valleys & \\
Paraffin & \\
Untreated Slopes & 4.7 \\
Rubberized asphalt & 4.7 \\
\end{tabular}

The relationships between slope treatment and wheat production is shown in Figure 1.7 . The effectiveness of a slope treatment is represented by an estimate of season-long soil water availability, which is the seasonal sum of the difference in soil water potential and -15 bars, times the days at that soil water potential, times the centimeters of soil profile at that water potential. As indicated on the plot in Figure 1.7 , the relationships between this estimate of seasonably available soil water and wheat production in the NS valleys is good with an $r^{2}$ of 0.98 . However, the slope treatments in the EW valleys explain only $29 \%$ of the variation in wheat yield, showing that wind erosion and weed growth had far more influence on wheat yield than soil water and slope treatment. 


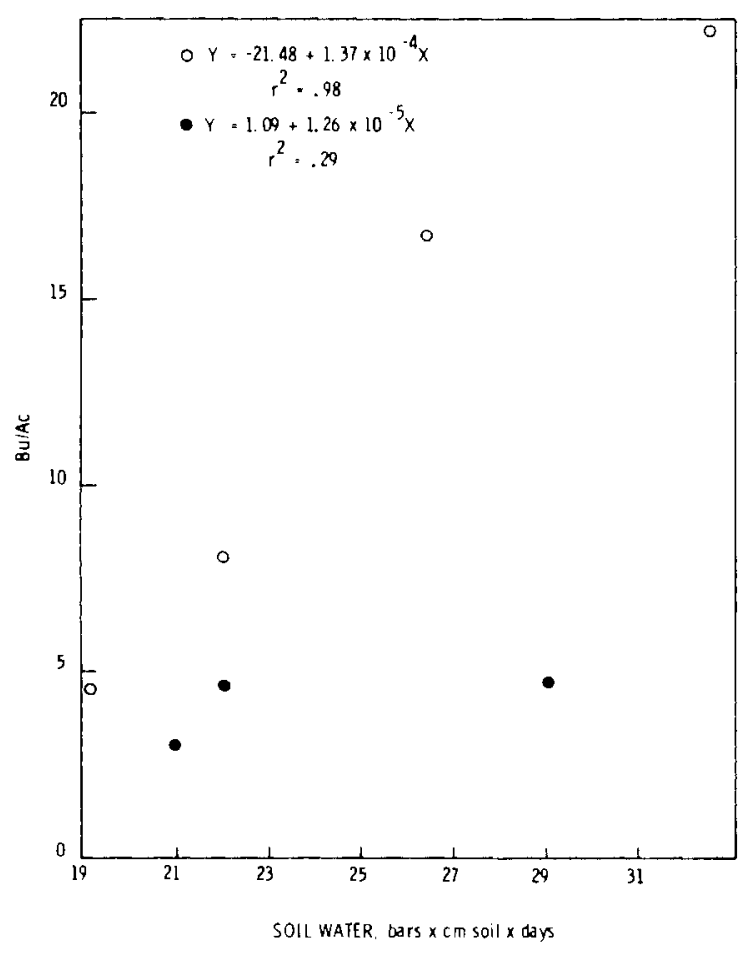

FIGURE 1.7. Plot of Relationship Between Seasonal Soil Water Availability and Wheat Production. Solid circles represent the $\mathrm{EW}$ valley orientation which experienced severe wind erosion. Open circles represent NS valley orientation where the amount of wheat produced was dependent upon slope treatment and it effectiveness in delivering runoff to the valley.
This alternative approach is also being tosted and demonstrated at the peabody coal 31 ack Mesa Mine in northern Arizona in cnoperation with the Universitv of Arizona. Spoil banks at the mine are being graded to 4-1 or 5-1 slopes and compacted to improve runoff characteristics. Results to date clearly show that quality and quantity of vegetative production can be improved in arid, disrupted regions by concentrating water and soil, growth factors in short supply, into a small cultivated area between the slopes of the spoil banks which supply rainfall runoff. 


\section{Literature Cited}

Bray, J. R. and Gorham, E. 1964. Litter

production of forests of the world.

Advances in Ecological Research 2: 101-152.

Harr, R. D. and Price, K. R. 1972.

Evapotranspiration from a phreatophyte

community. Water Resources Research 8:

1199-1203.

Hinds, W. T. 1975. Energy and carbon balances in cheatgrass: an essay in autecology. Ecological Monographs 45:

367-388.

Hinds, W. T. and Thorp, J. M. 1977.

Microclimates of the Arid Lands Ecology Reserve, 1968-1975. BNWL-SA-5231.

Battelle, Pacific Northwest Laboratories, Richland, WA.

Sauer, R. H. and Uresk, D. W. 1975.

Phenology of steppe plants in wet and dry years. Northwest Science 50 (3): 133-139. 


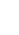




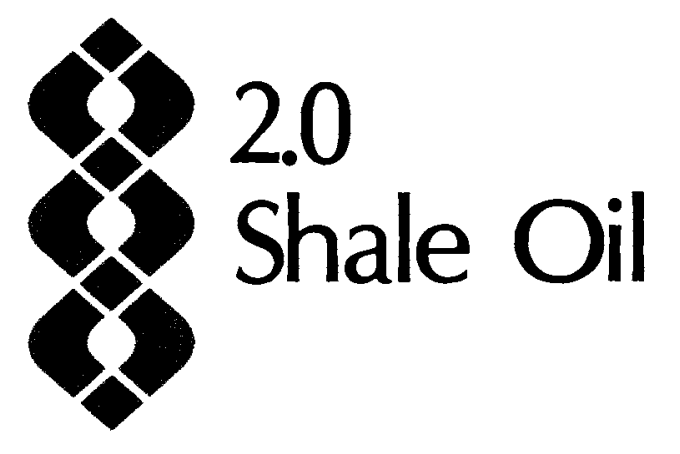




\section{SHALE OIL}

\section{- Terrestrial Effects of Oil Shale Development}

Vast domestic resources of oil shale may provide a long-term alternative to petroleum-derived fuel products. Methods proposed for obtaining shale oil from its deposits range from conventional mining and aboveground retorting technologies to in situ retorting. Although the technical and economic aspects of this wide range of options have been generally studied, the environmental impacts must be assessed as questions of siting, control technology, licensing and regulation can strongly affect the best production strategy.

Three major segments of the aboveground shale oil production cycle have potential for environmental consequences. These include mining of the shale, extraction of the shale oil and disposal of processed shale. In the mining process, aquifer disruption, runoff and movement of process residuals through the soil profile to groundwaters may result in impact on streams and rivers. During the extraction cycle (crushing, retorting and refining), the major impact will result from gaseous emissions and liquid effluents containing organic, macro-ion, and trace metal residues. Disposal of retorted shale presents problems in loss of recreation land, in reclamation of land occupied by retorted shale, and in environmental and human exposure resulting from resuspension of particulates and leaching of pollutants to ground and surface waters. The use of pyrolytic methods, together with a relatively high concentration of organic nitrogen and sulfur in oil shale, can lead to the formation of heterocyclic nitrogen components possibly resulting in environmental problems not ordinarily encountered in other energy industries.

The current PNL program focuses on the chemical characterization of effluent residuals (see PNL-2850, Part IV, Physical and Technological Programs), the potential toxicity of effluent residuals (see PNL-2850, Part I, Biomedical Sciences), and the chemical/microbiological processes leading to mobilization and plant uptake of inorganic and organic residuals (this report). Supporting research on the feasibility of revegetation in arid climates and application research on a water harvesting approach are described in Section 1.0 of this report, because they are of primary importance to surface mining of coal.

The specific studies reported in this section concern chemical/biochemical transformations in retorted shales and soils and their relationship to water quality, viability of green plants, and human food chains. This is a multitask interdisciplinary research approach which draws upon PNL capabilities in hydrocarbon chemistry, soil science, microbiology, and plant physiology. Principal objectives of the project are to 1) develop a basic knowledge of important extraction and environmental processes influencing the form, mobility, chemical and microbiological stability, 
plant availability, and toxicity of trace elements and organic residuals in retort waters and retorted shales, 2) model the movement of trace elements and stable organic residuals in soil and retorted shale, and 3) develop a rational basis for selection and subsequent laboratory and field testing of proper retort conditions/soil conditioners, irrigation waters and native or agricultural plant species to physiochemically stabilize and revegetate retorted shales for permanent, safe restoration of shale lands. The studies are being closely integrated with field investigations by other federal agencies and universities. Together, these programs should provide a basis for assessment of the potential terrestrial effects of waste disposal and for viable restoration of shale lands. 


\section{- Terrestrial Effects of Oil Shale Development}

Investigators: R. E. Wildung, T. R. Garland, R. M. Bean, D. A. Cataldo, W. E. Fallon, S. W. Li, K. M. McF adden, V. M. McNair, L. Neil, R. G. Riley, J. E. Rogers, K. Shiosaki and D. J. Silviera

The potential development of an oil shale industry requires the concomitant development of methodology to evaluate and ameliorate the environmental impact of waste disposal, principally retort waters and retorted shales.

Programs have emphasized 1) development of sampling protocols with industry, collection of samples from a range of retort processes, and physicochemical characterization of retort waters, retorted shales, retorted shale leachates and soils of the region, 2) column and field studies to determine the chemistry controlling the composition of leachates from retorted shale, 3) evaluation of the role of microbes in influencing the stability of organic residuals and formation of degration products in retorted shales and retort waters, and 4) the plant availability and effects of organic and inorganic residuals in retorted shale and retort waters.

Field studies of the stability and movement of trace metals and organic residuals in retorted shale disposed to the ground have been under way at the Paraho $0 i 1$ Shale Demonstration Project, an aboveground retort operated by Development Engineering Incorporated at Anvil Points, Colorado and in the Piceance Creek Basin, Colorado, in conjunction with Colorado State University. Planning is under way with DOE and industry to develop similar studies on actual sites in Colorado and Utah where in situ and modified in situ methods are being used. The results of laboratory and field studies have led to new concepts of the long-term nature of leachates from retorted shales and will be used to develop models of the mobility of organic and inorganic residuals in the oil shale region.

The program has provided technical and administrative support to current programs in integrated assessment of oil shale development, assessment by the National Academy of Sciences of redistribution of accessory minerals as a result of mining and extraction of oil shale, the $0 i 1$ Shale Environmental Development Plan, $0 i 1$ Shale Commercialization Environmental Readiness Document and to the DOE Task Force on Modified In Situ Development.

Properties of Effluents Disposed to the Ground-Organic Solubles

In order to predict the mobility and fate of organic residuals from oil shale development, it is essential to understand the nature of the initial effluent. Analytical methodology is being developed for characterizing organic residues from shale oil industry process effluents. Studies have focused on Paraho retort water from the Paraho $0 i 1$ Shale Demonstration Project.

Partial separation of organic from inorganic constituents of retort water was achieved by a methanol extraction of lyophilized retort water. The methanol extract contained $90 \%$ to $95 \%$ of the organic carbon in the starting sample of lyophilized whole retort water. Despite contamination of the 
organic (methanol-soluble) fraction with inorganic species, significant enrichments in percent composition of total sulfur, $\mathrm{NH}_{3}$, sulfur as $\mathrm{SO}_{4}{ }^{2-}$, and sulfur as $\mathrm{S}_{2} \mathrm{O}_{3}{ }^{2-} \mathrm{OC}-$ curred in the inorganic (methanol-insoluble) fraction (Table 2.1).

TABLE 2.1. Analyses of Lyophilized Whole Retort Water and Lyophilized $\mathrm{MeOH}$ Soluble and Insoluble Fraction.

\begin{tabular}{|c|c|c|c|}
\hline Component & $\begin{array}{c}\text { Whole } \\
\text { Retort } \\
\text { Water, \% }\end{array}$ & $\begin{array}{c}\mathrm{MeOH} \\
\text { Soluble } \\
\text { Fraction, \% }\end{array}$ & $\begin{array}{c}\mathrm{MeOH} \\
\text { Insoluble } \\
\text { Fraction, \% }\end{array}$ \\
\hline C & 20.15 & 26.68 & 1.82 \\
\hline$H$ & 6.24 & 6.30 & 5.91 \\
\hline$N$ & 14.45 & 12.64 & 17.98 \\
\hline$S$ & 21.42 & 18.01 & 37.08 \\
\hline$O^{(a)}$ & 37.08 & 35.48 & 36.92 \\
\hline Ash & 0.0 & 1.53 & 0.0 \\
\hline $\mathrm{NH}_{3}$ & 15.38 & 10.89 & 21.90 \\
\hline $\mathrm{Mg}$ & 0.44 & 0.64 & 0.18 \\
\hline $\mathrm{Na}$ & 0.22 & 0.25 & 0.11 \\
\hline $\mathrm{S}$ as $\mathrm{SO}_{4}=$ & 3.96 & 3.62 & 8.38 \\
\hline $\mathrm{S}$ as $\mathrm{SO}_{3}=$ & 4.74 & 0.0 & 0.0 \\
\hline $\mathrm{S}$ as $\mathrm{S}_{2} \mathrm{O}_{3}=$ & 9.47 & 4.91 & 28.69 \\
\hline Total $\mathrm{SO}_{4}=$ & 11.87 & 10.35 & 25.15 \\
\hline Total SCN- & 4.76 & 0.0 & 0.0 \\
\hline $\mathrm{S}$ as $\mathrm{SCN}^{-}$ & 2.63 & - & - \\
\hline $\mathrm{N}$ as SCN- & 1.15 & - & - \\
\hline $\mathrm{CN}^{-}$ & 0.0 & 0.0 & 0.0 \\
\hline Free S & 0.0 & 0.0 & 0.0 \\
\hline
\end{tabular}

(a) Difference determinations
TABLE 2.2. Percent Organic Carbon in Paraho Retort Waters Using USGS Method.

\begin{tabular}{lc} 
Fractions & $\begin{array}{c}\text { Organic Carbon, } \\
\%, \bar{n}=3\end{array}$ \\
\hline $\begin{array}{l}\text { Total HPO(a) } \\
\text { Total HPI }\end{array}$ & $\begin{array}{r}30.67 \pm 4.16 \\
69.33 \pm 4.16\end{array}$ \\
HPO - Acid & $16.00 \pm 1.00$ \\
HPO - Base & $6.67 \pm 0.58$ \\
HPO - Neutral (a) & $8.00 \pm 1.00$ \\
& \\
HPI - Acid & $60.00 \pm 2.00$ \\
HPI - Acid & $4.33 \pm 0.58$ \\
HPI - Neutral & $4.33 \pm 2.08$
\end{tabular}

(a) Difference determinations

currently being developed to further fractionate and/or characterize these fractions.

Solvent Solubilization of Organic Compounds in Retort Water

Verification of the structural types of water-soluble organic compounds present in retort waters has proved challenging. Preliminary investigations indicated that the organic components comprising retort waters were polar and hydrophilic, since they were poorly extracted from water into waterimmiscible organic solvents. To circumvent this problem, effort was directed towards development of chemical methods of transforming water-soluble organic compounds of retort waters into chemical forms that are more amenable to characterization and quantitation by classical analytical techniques.

The reaction of freeze-dried Paraho retort water from the Paraho 0 il Shale Demostration Project with boron trifluoride in methanol $\left(\mathrm{BF}_{3} / \mathrm{MeOH}\right)$ partially fulfills this need by converting $23 \%$ of the organic carbon to an organic solvent-soluble form. Capillary gas chromatographic/mass spectrometric analys is of a benzene extract of freeze-dried retort water treated with $\mathrm{BF}_{3} / \mathrm{MeOH}$ revealed a complex mixture of volatile organic compounds. Components of a homologous series of aliphatic monocarboxylic and dicarboxylic acids were identified from the mixture (Figure 2.1). Acids in both series were present at concentrations between 3.2 and 138 ppm. The method applies to monitoring the fate of organic acids in biological systems in which oil shale retort waters, retorted shales, or fractionated samples containing these compound types are used as substrates. Future studies will investigate other chemical derivation reagents which are specific for other compound types and suspected to be present in retort waters or retorted shales. 


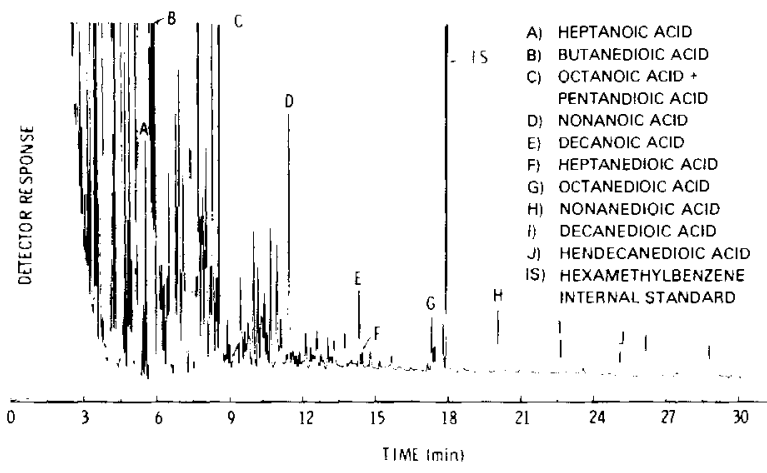

FIGURE 2.1. Capillary Gas Chromatogram of Benzene Extract of Freeze-Dried Retort Water After Reaction with $\mathrm{BF}_{3}-\mathrm{MeOH}$ (all as methyl esters).

Properties of Effluents Disposed to the Ground--Retorted Shale

The retorted shale used in field and laboratory studies was obtained from the Paraho 0 il Shale Demonstration Project. Continuing studies involve the behavior of shale components under a variety of laboratory conditions. These studies are designed to provide input for computer models currently being developed to help predict transport behavior observed in the field.

In these experiments, the solubility of salts due to leaching of retorted oil shales was determined as a function of equilibration time, particle size distribution, solution-to-solids ratios and simulated weathering conditions. One study involved mixing distilled water with retorted shale in batch equilibration systems. The results indicate that the solubilization of macroions occurred in at least two phases with initial solubility approaching a steady state after two to six days; solubility again increased and equilibrium was still not achieved after 95 days. In a second batch experiment, sieved fractions of retorted shale over a range of particle sizes from less than $0.15 \mathrm{~mm}$ to less than $6.3 \mathrm{~mm}$ affected the solution composition differently when incubated for $24 \mathrm{hr}$. Increases in the effective maximum particle size resulted in decreases in calcium (50x), magnesium (2x) and strontium $(10 x)$, and little change in $\mathrm{pH}$, electrical conductivity (ec) or sodium and potassium concentration. It was also found that higher solution-to-solids ratios (1:1 to 10:1) increased the solution concentration of calcium, strontium and magnesium, but did not affect sodium and potassium. In column studies involving leaching with distilled water, the $\mathrm{pH}$ of the leachate did not change from initial values of 11.5 to 12.5 , but ec was a function of flow rate and contact time of the percolate. Electrical conductivity ranged from approximately 30 mmhos/cm after 1 column volume to approximately 2 mmhos/cm after 5 column volumes. The role of temperature and the atmospheric composition surrounding the shale is also currently being evaluated for effects on the chemical composition of the column effluent. The results will help to increase our understanding of the chemical interactions which may occur within a retorted shale disposal pile, and will improve the ability to predict the behavior of shale components in actual field situations.

Mobility of Soluble Inorganic and Organic Residuals

\section{Laboratory Columns and Irrigated Field Sites}

In order to evaluate the potential impact on existing ground or surface water quality from the interaction of precipitation or irrigation water with retorted shale, it is necessary to understand the chemical or biological mechanisms which control the solubility and mobility of the residuals from disposed retorted shale. Field and laboratory studies have been undertaken to define the variables most important in changing the solubility and mobility of salts, trace metals, and organic components within the retorted shale profile.

Preliminary short-term laboratory studies showed that water leaches of retorted shale were saline (0.1-0.2 $\left.\mathrm{M} \mathrm{Na} \mathrm{SO}_{4}\right)$ and of high $\mathrm{pH}(11-12)$. Several column volumes of water were required to reduce either salinity or $\mathrm{pH}$. In contrast, leachates from field lysimeters indicated that the major soluble salts and organic residuals were removed in a pulse corresponding to approximately 0.2 column volumes. The initially high pH of leachates was significantly reduced by a single winter weathering season. The reduction of $\mathrm{pH}$ and changes in cation composition (increasing calcium and magnesium levels in the leachates) appears to be a result of the combined effects of several mechanisms, all of which may be directly or indirectly mediated by the demonstrated recolonization of the retorted shale by microorganisms. These mechanisms include 1) recarbonization of the shale from $\mathrm{CO}_{2}$, i.e., the chemical conversion of oxides to carbonates, ?) the reduction of five species to $\mathrm{SO}_{4}{ }^{2-}$ by oxidation, 3) the oxidation of $\mathrm{NH}_{4}$ to $\mathrm{NO}_{3}$ and 4) the oxidation of organic matter. The relative importance and the interactions of these mechanisms are currently under study.

A comparison of the leachates from area soils (derived, in part, from the weathered raw shale) and the irrigation water used reveals that, after one year of field weathering, the only trace elements leaching from the retorted shale in higher concentrations than from the soils or irrigation water are arsenic $(\times 2-10)$, molybdenum $(\times 5-10)$, boron 
$(x 0.15-1.5)$, and fluor ine $(x 2-10)$. Signif $i-$ cantly lower levels of uranium, copper, and clorine are leached from the retorted shale than the soil. The major differences between the leachates from retorted shale and area soils are in the alkaline earth or alkali metal elements, lithium (x200-400), sodium $(x 2-5)$, potassium $(x 10-30)$, calcium $(x 3-4)$, strontium ( $x \geq-3)$, and magnesium $(x 0.001-1.5)$.

Understanding of the mechanisms controlling the composition of leachates from retorted shale will have a major impact on not only the models being developed to assist the oil shale industry in waste disposal, hut also directly on the requirements which the industry must take to mitigate potential problems from waste disposal. Long-term field studies suggest that leachates are neutral or slightly acid, rather than being highly basic as originally hypothesized from short-term laboratory studies. This may significantly change the nature of the efforts required for design and revegetation of the retorted shale piles.

\section{Nonirrigated Field Site}

A field study was designed to examine problems associated with revegetation of a retorted shale disposal site and provide field validation of predictive models for movement of trace metals and organic residuals. The experimental design for this study is described in the Annual Report for 1977 , PNL-2500, Pt 2 .

One objective was to determine the physicochemical properties and homogeneity of the retorted shale and soil overburdens after the plots were prepared. Analysis of the chemical composition of these materials taken from many locations on the plots indicates that a homogeneous condition does exist for both the shale and soil overburden layers. A second objective was to determine the change in solubility and the overall movement of salts, trace metals and organic residuals within the soil shale profile. This is being accomplished by analyzing cores taken from the plots and by extracting moisture within the plots using porous ceramic cups which were installed at various depths in the fall of 1977. The water obtained from the cups will be analyzed for soluble components. This sampling routine will be conducted periodically, depending on the amount of precipitation falling on the site, and the results will be correlated with moisture movement through the profile.

The first samples from the ceramic cups were obtained in April 1978 following the spring thaw. This method of determining the concentration of soluble components at various depths within the retorted shale pile appears to produce good results. However, the maximum depth water was extracted and also the maximum movement of water as determined by neutron probe was approximately $90 \mathrm{~cm}$, suggesting that data from several years are needed hefore any conclusions can be made regarding the overall movement of soluble components.

Microbiology of Effluents Disposed to the Ground

Microbiology of Retort Water

The use of retort waters in dust control and compaction of retorted shale at disposal sites has been proposed. Retort water from the Paraho 0 il Shale Demonstration Project contains $4 \%$ dissolved organic carbon. The organic components of retort water appear to be a unique and complex mixture. Preliminary studies indicate that the organics are extremely polar, hydrophilic, and poorly extracted into less polar solvents immiscible with water.

One of the principal factors influencing the stability and possible toxicity of retort waters within retorted shale disposal sites will be the activity of the indigenous microorganisms. Studies were initiated to determine the effects of retort waters on microorganisms and the effects of microorganisms on retort water. These studies are concerned with the bacterial and fungal components of the soils in the area proposed for retorted shale disposal sites. Bacteria and fungi were found to utilize retort water as the sole source of carbon and energy. Added phosphate was essential since cultures containing no phosphate supported only minimally detectable growth. The addition of a nitrogen or sulfur source was not required.

The utilization of organic residues in retort water by microorganisms were monitored by measuring the decrease in dissolved organic carbon of both bacterial and fungal cultures. Cultures ( $100 \mathrm{ml}$ final volume) contained 4\% v/v retort water, $100 \mathrm{mg}$ Anvil clay soil, $40 \mathrm{mM} \mathrm{Na} \mathrm{HPO}_{4}, 40 \mathrm{mM} \mathrm{KH}_{2} \mathrm{PO}_{4}$ and either $10 \mathrm{ppm}$ fungizone or $30 \mathrm{ppm}$ streptomycin plus $30 \mathrm{ppm}$ tetracycline. The initial $\mathrm{pH}$ of bacterial and fungal cultures was 6.3 and 7.2 , respectively. Cultures were incubated at $25 \mathrm{C}$ with rotary shaking at $150 \mathrm{rpm}$. Under these conditions, bacterial cultures decreased the dissolved organic carbon content of retort water to a larger extent than fungal cultures (Figure 2.2). The maximum decrease in dissolved organic carbon was reached within 25 days by bacterial cultures whereas fungal cultures reached a maximum within 10 days of incubation. Continued incubation up to 55 days did not appreciably alter the concentration of dissolved organic carbon.

Studies were also started to determine the effects of retort water concentration on the 


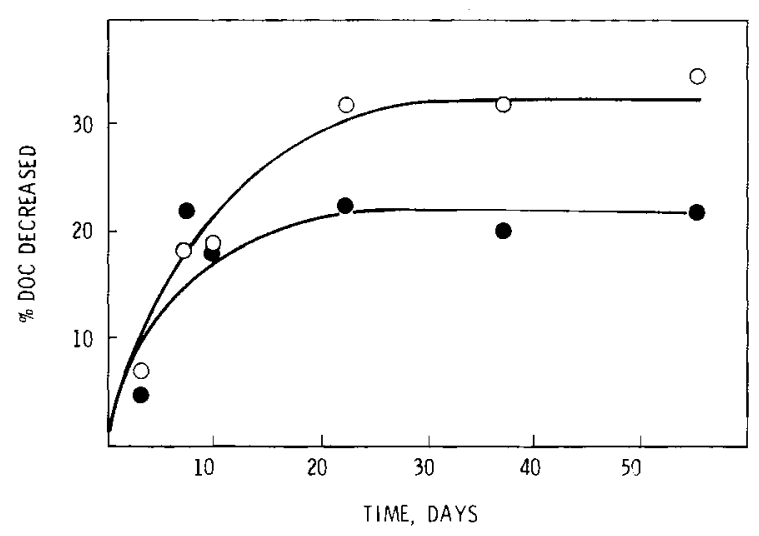

FIGURE 2.2. Bacterial and Fungal Utilization of Retort Water Dissolved Organic Carbon.

bacterial utilization of the organic residuals in retort water. Preliminary results indicate that retort water concentration up to $10 \% \mathrm{v} / \mathrm{v}$ does not significantly affect the percent decrease in the dissolved organic carbon. After 21 days of incubation, approximately $20 \%$ of the dissolved organic carbon was utilized by bacterial cultures containing $2,4,6,8$, and $10 \% \mathrm{v} / \mathrm{v}$ retort water.

These studies are continuing and will be expanded to include studies of the effects of retort water on the growth of microorganisms, the microbiological colonization of retort water and retorted shale mixtures, and the degradation of important soluble organic compounds identified from retort waters.

\section{Microbial Colonization of Retorted Shale}

Previous studies show that total heterotrophic bacterial populations of soil samples and retorted shale obtained in June 1977 from the lysimeters at Anvil Points, Colorado containing retorted shale from the Paraho $0 i 1$ Shale Demonstration Project were similar $\left(\sim 3 \times 10^{6}\right.$ bacteria/g dry wt). However, the bacterial population of the retorted shale sample was dominated by a single organism that composed $30 \%$ of the total population. The relative total heterotrophic bacterial populations of retorted shale and soil samples obtained in April 1978 were again simi1 ar $\left(1.0 \times 10^{7}\right.$ bacteria/g dry wt) but slightly elevated over the June 1977 samples.

In June 1978, a $1.5 \mathrm{~m}$ core sample was obtained from the lysimeter at Anvil Points. The core was divided into five $.3 \mathrm{~m}$ sections. Each section was thoroughly mixed and subsampled for determination of total heterotrophic and anaerobic bacteria and fungi. As shown in Figure 2.3, the fungal population was highest in the first $.3 \mathrm{~m}\left(4.5 \times 10^{4}\right.$ fungal units/g dry wt) and decreased to less than 100 fungal units/g dry wt at the $1.5 \mathrm{~m}$ level.

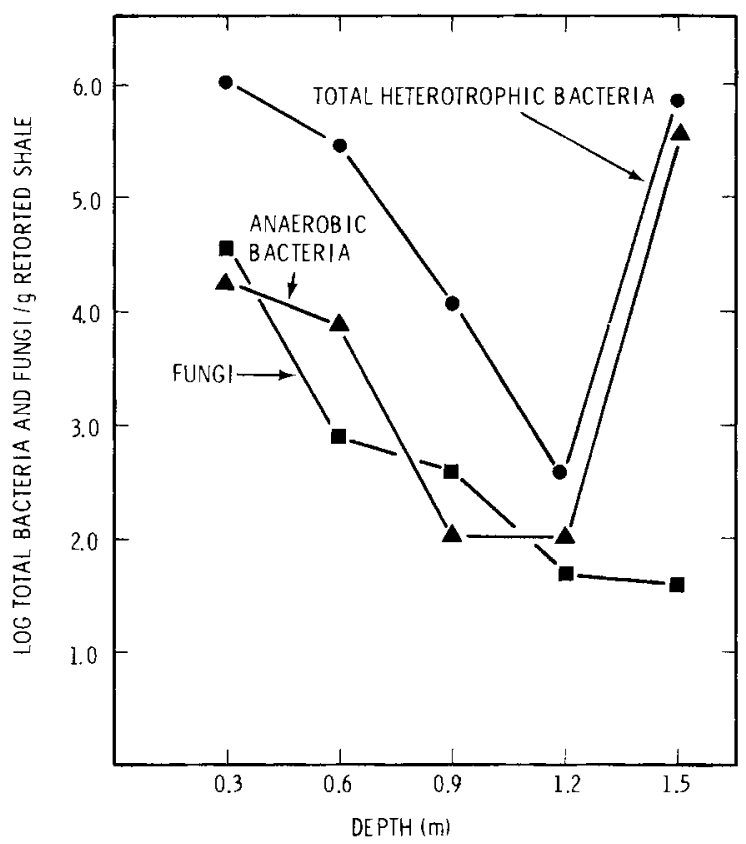

FIGURE 2.3. Depth Profile of the Microbial Colonization of Irrigated Retorted Shale.

The heterotrophic and anaerobic bacteria decreased in population from the $.3 \mathrm{~m}$ level $\left(1.1 \times 10^{6}\right.$ bacteria/g dry wt and $1.9 \times 10^{4}$ bacteria/g dry wt) to the $1.2 \mathrm{~m}$ level (4.2 $\times 10^{3}$ bacteria/g dry wt and less than 100 bacteria/g dry wt); however, both bacterial populations increased at the $1.5 \mathrm{~m}$ level $\left(1.1 \times 10^{6}\right.$ bacteria/g dry wt and $3.9 \times 10^{5}$ bacteria/g dry wt). The highest ratio of anaerobic to heterotrophic bacteria was observed at the $1.5 \mathrm{~m}$ level just above the compacted zone which has been shown to be saturated with water. This suggests that anaerobic conditions may be developing at and below the $1.5 \mathrm{~m}$ level.

In laboratory studies using liquid cultures which contained $10 \mathrm{~g}$ retorted shale, $100 \mathrm{mg}$ soil, and $100 \mathrm{ml}$ of sterile salts

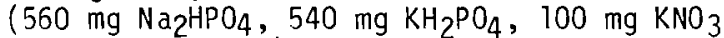
and $500 \mathrm{mg} \mathrm{MgSO}_{4}$ ), bacteria grew on retorted shale as the sole source of carbon and energy. The absence of either phosphate, $\mathrm{KNO}_{3}$, or $\mathrm{MgSO}_{4}$ did not decrease the level of bacterial populations; however, the absence of phosphate lengthened the lag phase of growth to the greatest degree. The bacterial populations from these studies were dominated (greater than $90 \%$ ) by bacteria with colony morphologies and growth characteristics similar to those found to dominate the retorted shale field sample (June 1977). These organisms have been identified as gram-positive cocci. The growth of the organisms on retorted shale may, in part, be attributed to their ability to grow over a wide range 
of $\mathrm{pH}(7.0-10.0)$ and salt concentrations $(0-5 \%, \mathrm{NaCl})$. These results are consistent with the $\mathrm{pH}(11-12)$ and the salt concentration (1-3\%) of the initial leachates obtained from the lysimeter in June 1977.

These studies show that bacteria can utilize the organic residues of retorted shale for growth and can modify the organic composition of the retorted shale, which may have an important effect on the mobility of trace metals. This work will be expanded to determine the types and numbers of additional microorganisms which develop on retorted shale with environmental aging. Studies are also being initiated to measure the rate and extent of microbial decomposition in retorted shale leachates and representative watersoluble residual organic compounds.

\section{Physiological Effects of Effluents on Plants}

Preliminary studies with $\mathrm{P}$ araho retort water from the Paraho $0 i l$ Shale Demonstration Project showed effects on plant growth when present in excess of $0.5 \% \mathrm{v} / \mathrm{v}$. These included reduced water usage, chlorosis, dry matter production and a marked drop in rhizosphere $\mathrm{pH}$. There were no detectable effects on tissue respiration or ion absorption. Based on the observed toxicity of retort water, investigations were initiated to determine the physiological effects of the major inorganic species and organic fractions of retort water.

Retort water was fractionated using a combination of solvent and macroreticular resin procedures. This yielded methanol insolubles (inorganic fraction) and methanol solubles (organic fraction) consisting of hydrophobic and hydrophilic acids, bases, and neutrals. of six organic fractions tested, only the hydrophilic acids induced phytotoxic behavior (i.e. chlorosis) and reduced dry matter production of both roots and shoots. The methanol-insoluble fraction, which contains primarily inorganic salts, accounted for the majority of the phytotoxicity observed, i.e. reduced water usage, reduced rhizosphere $\mathrm{pH}$ and leaf burn.

Characterization of the inorganic components of Paraho retort water showed several species to predominate $\left(\mathrm{SCN}^{-}, \mathrm{SO}_{3}{ }^{2-}\right.$ and $\mathrm{S}_{2} \mathrm{O}_{3}{ }^{2-}$ ) which may account for the observed effects. These were supplied to plants at levels equivalent to their concentration in retort water, and their effects on plants noted. Reduced water usage was observed for all three species, but especially for $\mathrm{SCN}^{-}$. Rhizosphere $\mathrm{pH}$ effects and reduced dry matter production were noted with $\mathrm{SO}_{3} 2-$ treatments. Pronounced leaf burn was observed in treatments with $\mathrm{SO}_{3}{ }^{2-}$ and $\mathrm{S}_{2} \mathrm{O}_{3}{ }^{2-}$. Based on these studies, it would appear that at least the initial toxicity of retort water is due to inorganic constituents.

Studies are being extended to indigenous species such as four-wing saltbrush and to a comparison of plant responses to retort water from in situ extraction processes and deep well waters. In the latter case, preliminary results show retort waters from in situ operations to produce little adverse effects on plants, with uncontaminated deep well waters exhibiting much more pronounced toxic effects. 


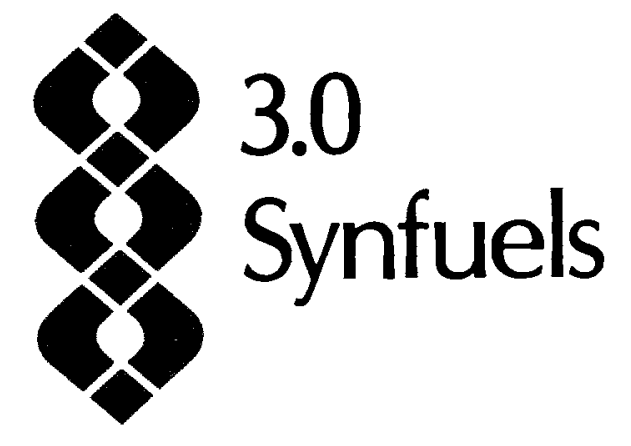




\section{SYNFUELS}

In his environmental message of May 1977, the President of the United States declared a national commitment to reduce reliance on foreign oil through increasing use of our own vast coal reserves. He admonished, however, that we were to do this in a way that protects the quality of our environment. To meet this challenge, government and industry have entered into an unprecedented series of cooperative efforts to develop new energy technologies. Their purpose is to convert coal to oil substitutes and alternate fuels that burn more cleanly than their parent coals. Among these coal conversion technologies are those in which slurried coal is subjected to high heat and pressure, causing the coal to liquefy.

The development timelines for three of the most promising coal liquefaction technologies, Solvent Refined Coal (SRC), H-Coal, and Donor Solvent, show that commercial plants are expected to be built and operational by 1987 in all three cases. This means some major decisions on commercialization have to be made in 1980 or 1981, and the time frame for conducting the necessary research to assure that these decisions will be environmentally sound is uncomfortably short.

Of the three most promising coal liquefaction technologies, SRC is the first expected to reach the demonstration stage of development. Design of the demonstration facility will derive largely from experience gained at a 50-ton-per-day SRC pilot plant at Fort Lewis, Washington.

The work described herein is PNL's part of a larger research program on coal synfuels being implemented by the Department of Energy. In order to obtain maximum return on investment over the whole program, the ecological characterization task is being coordinated with complementary programs at PNL (Biology and Physical Science Departments) and at Oak Ridge National Laboratory. Tests are being run on the same source materials and under comparable conditions whenever possible.

The PNL research program is currently expanding to include more of the most likely avenues of environmental change from solvent refining of coal. An important element of this expansion is to identify the source materials and variations of source materials most in need of ecological investigation. This requires increased collaboration with technology developers and process engineers.

As a basis for the ecological research strategy, it is assumed that a developing technology can be described in two ways: in terms of physical and chemical properties of liquid, solid and gaseous materials it produces (source terms), and in terms of the environmental effects of perturbations that these materials may cause. It is further assumed that the wide variety of possible source terms, coupled 
with a multitude of possible biological effects from each, makes it impossible to characterize a technology completely, both physically and biologically. Instead it is necessary to employ a "top-down" strategy, by which we first ask, "Is there an effect?"

Under this strategy, chemical characterization may be limited to relatively inexpensive "indicator" tests until potentially significant biological problems are observed. Only then would more detailed analyses of an archived sample be initiated to track down the source of the problem. This approach is most fruitful as applied to liquid SRC products and waste materials. A somewhat modified approach is needed to deal with leachates from solid products and waste materials, requiring greater emphasis upon preliminary chemical analyses of variously derived leachates in order to bracket the ranges within which biological tests should be conducted. 


\title{
- Synfuels
}

\author{
Principal Investigators: R. M. Bean, \\ C. D. Becker, T. M. Poston, M. J. Schneider \\ and J. B. States \\ Other Investigators: S. A. Barraclough, \\ R. G. Genoway, A. J. Scott, and J. A. Strand \\ Technical Assistant: M. G. Wolford
}

This program represents the Ecosystems Department component of a cooperative effort to facililitate the development of environmentally amenable coal conversion technologies. Participants in this endeavor are the Biology and Physical Sciences Departments of Battelle, the Department of Energy, Oak Ridge National Laboratory, and other technology developers. The objectives of Ecosystems' component are to ecologically characterize the products, process streams and effluents of Solvent Refined Coal (SRC) technology on the basis of source materials from a pilot plant sited at Fort Lewis, Washington; to determine the environmental fate and effects of these materials; and to obtain sufficient information to predict ecologically significant impacts as input to technology development decisions.

Acute Toxicity of Solvent Refined Coal Effluents--Toxicity Tests

We have used static, short-term exposures of fish to various dilutions of Solvent Refined Coal (SRC) effluent in preliminary evaluation of toxicity. Such toxicity tests are commonly adopted in initial evaluations of liquid byproducts arising from a new technological process. In considering the toxicity testing described below, one should keep in mind that the effluent treatment process finally adopted will probably differ from the process used at the time these tests were run. Part of the purpose in carrying out the toxicity tests is to provide data to guide engineering development at the pilot plant.

Observed mortality of test organisms ranged from zero to $100 \%$ (Table 3.1 ). Inconsistency in relative toxicity could be caused by a variety of conditions, including 1) condition of the charcoal filter below the biodigester (i.e., its effectiveness in sorbing low molecular weight and soluble organics); 2) $\mathrm{pH}$ level in the biodigester to the degree that it controls the abundance of microorganisms breaking down hydrocarbons; 3 ) the waste treatment unit operating condition when the effluent sample was obtained;

4 ) the extent of effluent dilution with potable cooling water or tap water, and 5) the specific process used.

Tests during the SRC I mode of plant operation yielding a solid product used treated process effluent obtained from the discharge pipe. The results indicated that treated SRC I effluents were relatively low in acute toxicity. This was apparently due largely to the effectiveness of the biodigester, followed by sand and activated carbon filtration. However, a slow narcosis of test organisms, or an impairment of their functioning, was often noted, suggesting that longer exposure would have proved lethal. (This should be kept in perspective as the pilot plant routinely dilutes its treated process effluent with tap water before discharge.) Tests run under the SRC I process yielding liquid products were influenced by abnormal plant operations, which resulted in effluent that did not pass through the biodigester and filter to reduce hydrocarbon loading. Results of tests in this water indicated that, as expected, incompletely treated or untreated SRC I effluent was toxic to aquatic life.

At about the time of changeover from SRC I to SRC II operations it became necessary to supplement with tap water the potable cooling 
TABLE 3.1. Summary of Results from 96-hr Static Laboratory Toxicity Tests with Treated SRC Process Effluent at $17-19 \mathrm{C}$. Effluent was collected at the P\&M SRC pilot plant, Fort Lewis, Washington one day before start of each assay.

\begin{tabular}{|c|c|c|}
\hline $\begin{array}{l}\text { Date Assay } \\
\text { Conducted }\end{array}$ & $\begin{array}{l}\text { Test } \\
\text { Organisms }\end{array}$ & Assessment $(a)$ \\
\hline & & SRC I \\
\hline Aug 3-7, 1976 & $\begin{array}{l}\text { Rainbow trout (Salmo } \\
\text { gairdneri) fingerlings }\end{array}$ & $\begin{array}{l}\text { No relationship between mortality and effluent concentration. Losses } \\
\text { due to low dissolved oxygen. }\end{array}$ \\
\hline Aug 24-28, 1976 & $\begin{array}{l}\text { Largemouth bass } \\
\text { (Micropteris salmoides) } \\
\text { fingerlings }\end{array}$ & $\begin{array}{l}\text { No mortality attributable to effluent concentration. Some losses due } \\
\text { to disease. Some stress display by fish. }\end{array}$ \\
\hline Oct $12-16,1976$ & $\begin{array}{l}\text { Rainbow trout } \\
\text { fingerlings }\end{array}$ & Significant mortality $(>50 \%)$ at effluent concentrations of 80 and $100 \%$ \\
\hline Nov $16-20,1976$ & $\begin{array}{l}\text { Rainbow trout and } \\
\text { crayfish }\end{array}$ & $\begin{array}{l}\text { Significant mortality ( }>50 \% \text { ) at effluent concentrations of } 40,60,80 \\
\text { and } 100 \% \text { for rainbows, }>60 \% \text { for crayfish; narcosis evident among } \\
\text { crayfish. }\end{array}$ \\
\hline Jan $27-31,1977$ & Rainbow trout fry & $\begin{array}{l}\text { No mortality in } 96-\mathrm{hr} \text { but some fish stressed at } 80 \text { and } 100 \% \text { effluent } \\
\text { concentrations. }\end{array}$ \\
\hline
\end{tabular}

SRC II

June 21-25, 1977 Rainbow trout Some mortality at higher effluent concentration. fingerlings

Dec 14-18, 1977 Rainbow trout fry

No mortality attributable to effluent concentration.

Feb $17,1978 \quad$ Rainbow trout fry

Total mortality at all effluent dilutions. Test terminated after $30 \mathrm{~min}$ and repeated with higher dilutions.

Feb 17-21, $1978 \quad$ Rainbow trout fry

Over $80 \%$ mortality at low effluent concentrations of 6,8 and $10 \%$ (repeat).

Mar 24-28, $1978 \quad$ Rainbow trout fry Over $90 \%$ mortality at effluent concentrations of 60,80 and $100 \%$.

(a) Factors influencing relative toxicity were condition of charcoal filter below biodigester, $\mathrm{pH}$ level in biodigester, stage of plant operational stage when sample was obtained, effluent dilution, and mode of plant operation (SRC I or SRC II).

tower water supplied to cooling jets on the Sandvik belt. This reduced high cooling tower losses from Sandvik operation which had interfered with efforts to maintain cooling tower water chemistry and noncorrosive conditions. At the same time it significantly increased the dilution of effluent waters being tested for aquatic effects during all subsequent testing periods. Results of the first two acute toxicity tests conducted during SRC II indicated low toxicity hut a narcotic effect, similar to tests conducted during "normal" operation of SRC I. However, considerable toxicity of untreated process effluent was subsequently indicated when abnormal plant operating conditions prevailed. When the surge reservoir was cleaned before the effluent samples were obtained, highly acidic wastes inadvertently entered the biodigester, killing most of the microorganisms.
Thus, the effluent used in the acute toxicity test was untreated and, as might be expected, highly toxic. In the first test, all fish soon died and the test was terminated in 30 min. The subsequent test employed greater dilutions of the same effluent sample. Again, high toxicity was indicated.

In summary, short-term toxicity tests with SRC plant effluent indicate that treated process effluent passing through the biodigester, sand filter, and activated charcoal filter is relatively low in toxicity to aquatic life, and that untreated effluent originating within the plant contains chemical features highly toxic to aquatic life. It is clear that sampling of effluent issuing from a pilot plant must be closely correlated with a specific mode of plant operation, and that an effective biological treatment unit 
is required of effluent originating from a commercial operation.

Chemical Characterization of Solvent Refined Coal Effluents

A temporary failure of the SRC liquid effluent treatment facility in February, 1978 provided a unique opportunity to collect samples of untreated effluent for hydrocarbon analysis. These samples were compared with those collected from the same location when the treatment facility was fully operational. In each case, the organic material in the water was collected by pumping the effluent discharge directly through tubes filled with macroreticular resin. The tubes were extracted with $100 \mathrm{ml}$ diethyl ether to remove the organic material. Then the ether extracts were concentrated and the hydrocarbons in the extracts separated into saturate and aromatic hydrocarbon types using a standard silica gel separation procedure. These fractions were investigated using capillary gas chromatography and capillary gas chromatography/mass spectrometry (GC/MS).

Figure 3.1 shows a capillary chromatogram of the aromatic hydrocarbons isolated from
$0.56 \&$ of effluent when the water treatment facility was inoperative (top) and compares this with the aromatic hydrocarbons isolated from $10 \ell$ of treated effluent (bottom). It is difficult to accurately determine the quantities of material being discharged at any time, because the amount of water added to the waste stream from cooling operations and other relatively uncontaminated sources varies widely. However, it is apparent that the untreated effluent sample contained at least two orders of magnitude more material than did the treated effluent. The qualitative differences are also dramatic. CG/MS analysis of the untreated effluent sample revealed a wide variety of alkyl substituted naphthalenes, biphenyls, fluorenes, phenanthrene/anthracenes, and pyrenes. Most of the major chromatographic peaks appearing in the untreated effluent sample are absent from the treated sample.

Work is in progress to identify all the major components appearing in both effluent samples. Knowledge of the composition of the treated effluent will allow an assessment of the effectiveness of the treatment operation and point the way toward any necessary improved procedures.

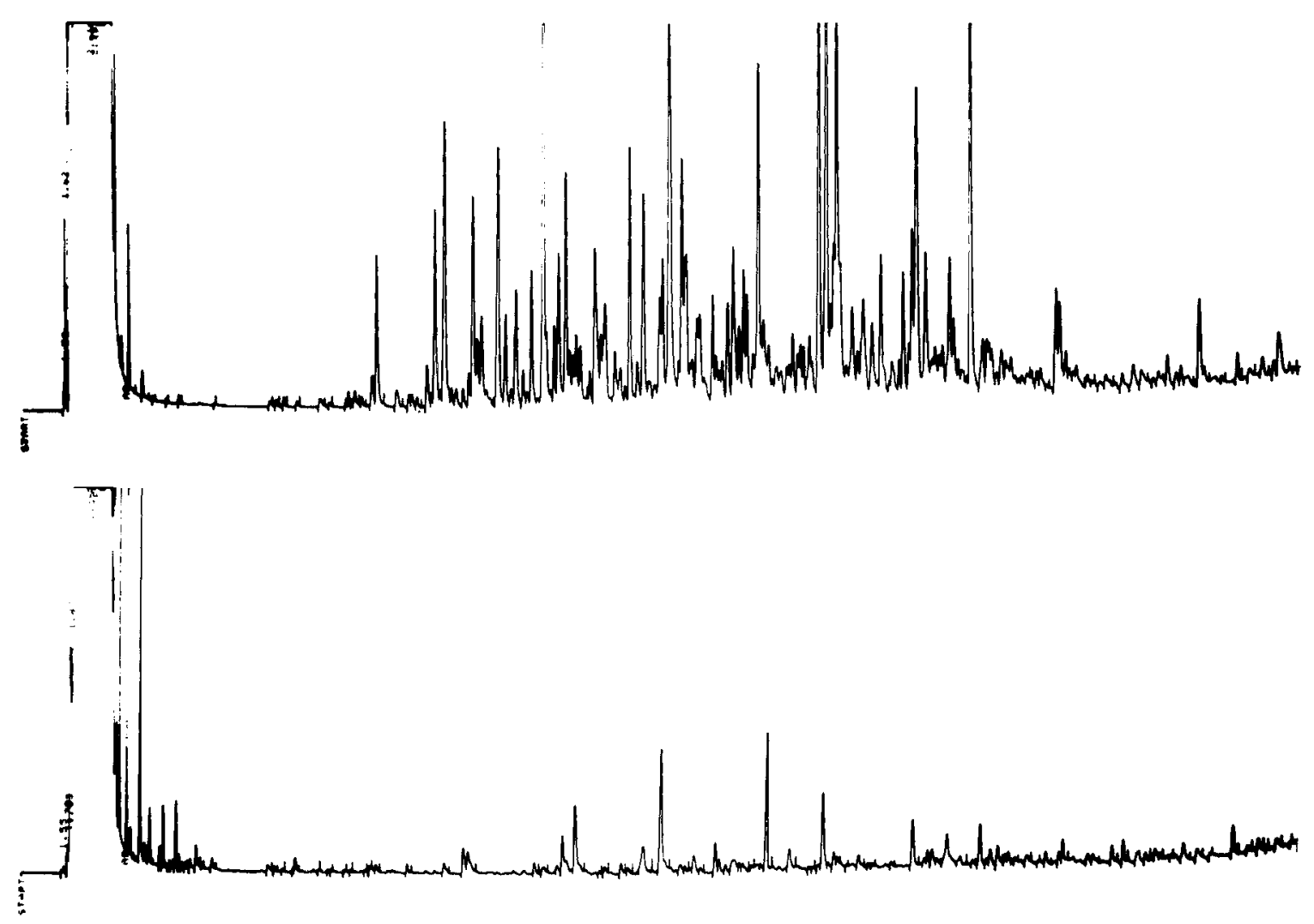

FIGURE 3.1. Capillary Gas Chromatograms of Solvent Refined Coal Effluent, Aromatic Hydrocarbons. Above, untreated effluent; below, treated effluent. Treated effluent has been concentrated 15 times that of the untreated effluent. 
Effects of Sublethal Phenol Exposure on Predator-Prey Relationships

The studies reported here were initiated under a former 189 entitled "Immediate Effects of Coal Utilization on Fish Physiology and Behavior." Because the developing SRC technology required more immediate attention, the fish behavior investigations were temporarily interrupted. The results of these studies to date are reported below.

The research investigated the use of physiological and behavioral indicators to detect the environmental effects of coal-related contaminants entering aquatic systems with greater sensitivity. The interaction of predator and prey was selected for investigation. Companion studies at PNL indicated that the phenols were representative of SRC waste streams connected with coal conversion processes.

The experimental design of our studies required exposing juvenile rainbow trout (Salmo gairdneri) to sublethal levels of phenol before exposing them to adult trout predators. Acclimation and test temperatures were $13.0+1.0 \mathrm{C}$. Following a 96-hr exposure, test fish and an equal number of control fish were put into a tank containing adult predators (rainbow trout). Each test lasted a maximum of $30 \mathrm{~min}$ or was terminated when approximately half of the prey had been consumed. Fish remaining at the end of the test were recorded as exposed or control according to pretest marking.
Exposure concentrations ranging from approximately 0.4 to $7.7 \mathrm{ppm}$ were generated by proportional diluters and were selected based upon reported lethal concentrations ranging from 10-25 ppm.

The ratio of predation rates upon two groups of fish was $d p=i_{1} / i_{2}$, where $i_{1}$ and if are the instantaneous mortality rates of the exposed and control groups, respectively. Figure 3.2 is a plot of the dp ratio versus the phenol concentration for 62 individual tests. The linear regression shows a significant trend in the data. The slope of the line $(0.20)$ is significantly different from $0(p<0.05)$, and with a correlation coefficient of 0.50 there is a significant $(p<0.05)$ relationship between the dp ratio and phenol. Thus, there is a trend of increasing vulnerability to predation with increasing phenol concentration. However the individual test ip ratios do not indicate a significantly greater predation rate of exposed fish compared to controls until the highest test concentrations, i.e., 7.03 and $7.74 \mathrm{ppm}$. This suggests that the level of sensitivity of the predator-prey test may be only slightly higher than that realized by using a standard 96-hr determination of $\mathrm{LC}_{50}$.

Effects of Phenol on Gill Adenosine Triphosphatase

One aspect of investigation dealing with sublethal stress in aquatic organisms has been the effect of pollutants upon enzyme

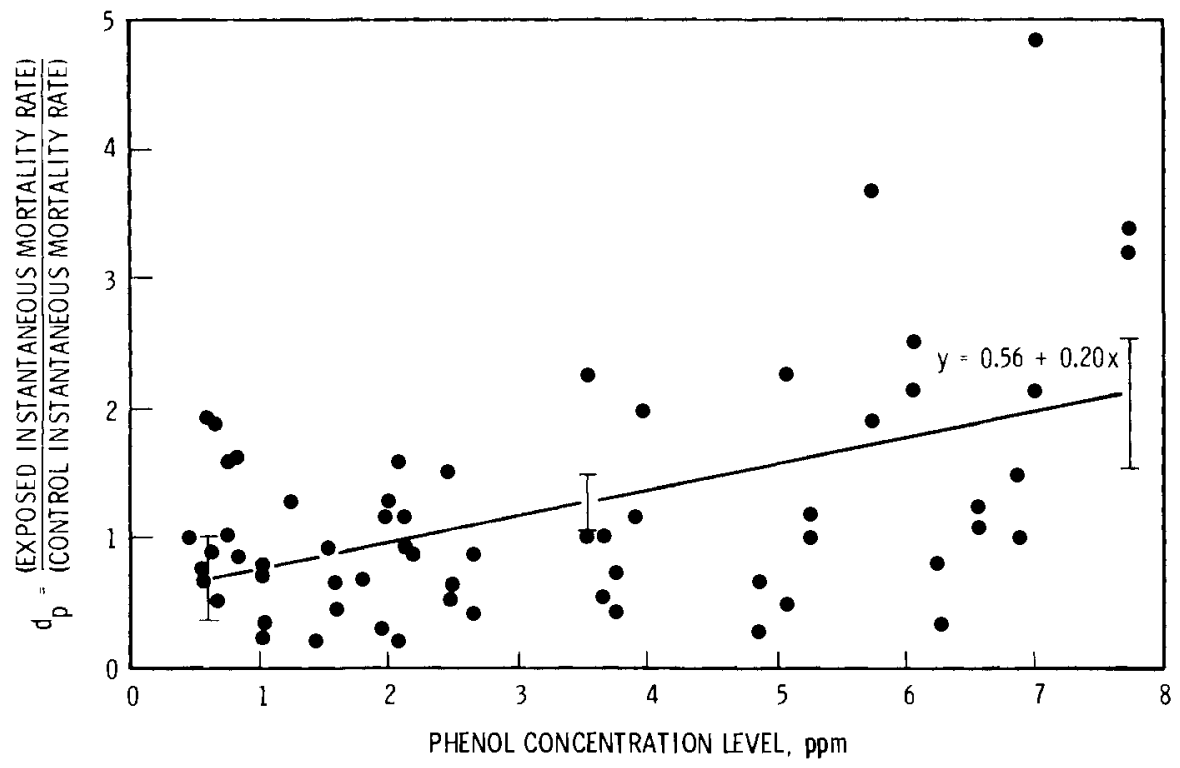

FIGURE 3.2. Plot of the dp Relationship Versus the Phenol Concentration for 62 Individual Tests on Predator-Prey Relationships in Rainbow Trout. 
systems. Research on adenosine triphosphatase (ATPase) has received attention in the literature, with major emphasis on organochloride pesticides. Analysis of SRC effluents identified phenol as one of the more persistent constituents. This compound was selected as the initial test toxicant for ATPase activities.

Experiments were conducted to determine optimal assay conditions for three ATPase activities associated with crude gill homogenates of rainbow trout. Definitions of these activities and assay conditions for toxicity are listed below:

- Mg-baseline--the amount of activity stimulated solely by magnesium ions. Assay conditions were $20 \mathrm{C}$, pH $7.0(10 \mathrm{mM}$ imidazole buffer) and $3.25 \mathrm{mM} \mathrm{Mg+}^{2}$.

- Total Nak=ATPase--the total amount of activity observed in the presence of magnesium, sodium and potassium ions. Assay conditions were $20 \mathrm{C}$ and $37 \mathrm{C}, \mathrm{pH} \mathrm{7,0}$ (10 $\mathrm{mM}$ imidazole buffer), $3.25 \mathrm{mM} \mathrm{Mg+2}, 100$ $\mathrm{mM} \mathrm{Nat}$ and $20 \mathrm{mM} \mathrm{K+}$.

- Sodium pump activity (ouabain-sensitive NaK=ATPase) --the fraction of activity stimulated by magnesium, sodium and potassium ions and inhibited by oubain, a cardiac glycoside. Assay conditions are identical to those for total NaK-ATPase with the addition of $0.5 \mathrm{mM}$ ouabain.

Initial efforts were directed towards the characterization of these ATPase activities. We found that all three activities exhibited a rather broad $\mathrm{pH}$ optimum between 6.0 and 7.3. Thermal lability was observed in both Mg-baseline and total NaK-ATPase activities in excess of $30 \mathrm{C}$ and $20 \mathrm{C}$, respectively. Sodium pump activity, was demonstrated only at 37C. At this temperature total NaK-ATPase activity did not exceed Mg-baseline activity, indicating a lack of alkali metal stimulation. It was also observed that magnesium ion concentration in excess of $5 \mathrm{mM}$ appeared to inhibit total NaK-ATPase activity. Neither $\mathrm{Na}^{+}$or $\mathrm{K}+$ demonstrated any stimulatory effect on ATPase activity at $37 \mathrm{C}$.

Experiments were performed to assess the in vitro effects of phenol on ATPase activities. Mg-baseline activity was less sensitive than total NaK-ATPase activity. In two separate tests, Mg-baseline was inhibited $43 \%$ and $35 \%$ by $20 \mathrm{mM}$ phenol, whereas total NaKATPase activities were inhibited $58 \%$ and $57 \%$. Sodium pump activity was unaffected by phenol at concentrations as high as $25 \mathrm{mM}$ phenol. The mode of inhibition was determined as uncompetitive by inspection of Eadie-Hof stee plots (Figure 3.3 ).
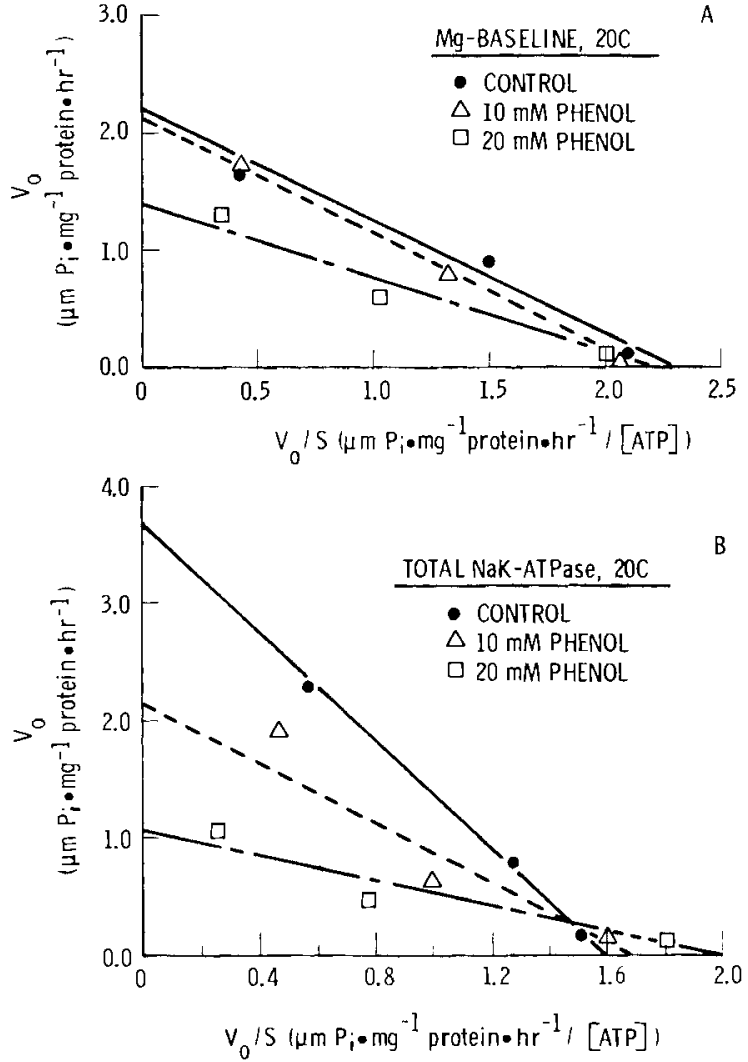

FIGURE 3.3. Inhibition of Mg-Baseline (A) and Total NaK-ATPase (B) Activities at 20C. Solid dots and solid lines represent controls (i.e., no phenol). Ten $\mathrm{mM}$ and $20 \mathrm{mM}$ phenol are represented by triangles (dashed line) and squares (alternating dashed line) respectively. ATP concentrations were $0.1,0.6$ and $4.0 \mathrm{mM}$. Each point represents the mean of three fish.

Phenol does not appear to have the potential to adversely affect gill ATPase activities in vivo. Conversion of millimolar concentrations of phenol to $\mathrm{mg} \cdot \ell(20 \mathrm{mM}$ phenol $=$ $1,882 \mathrm{mg} \cdot \ell$ ) shows that ppt levels would have to accumulate in the gills to produce a significant level of inhibition. The $\mathrm{LC}_{50}$ levels of phenol range between $6-25 \mathrm{mg} \cdot \ell$ for freshwater teleosts, indicating that death would most likely precede any detectable sublethal effects associated with gill ATPase activities. 



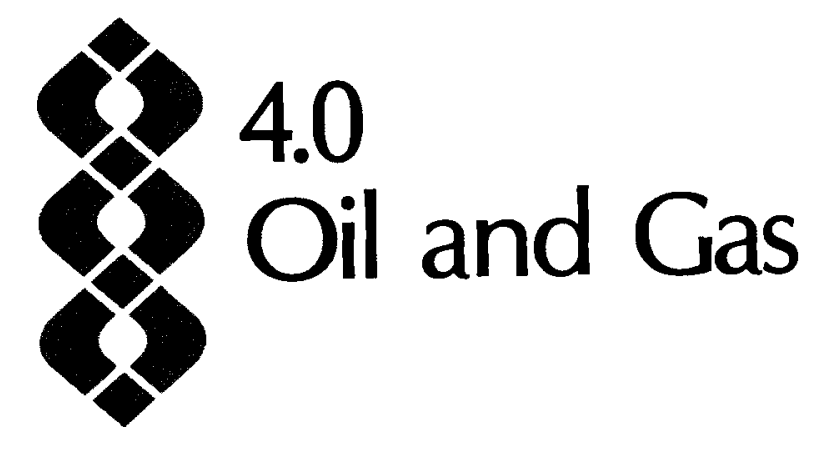




\section{OIL AND GAS}

\section{- Fate and Effects of Petroleum Hydrocarbons in Marine Ecosystems}

\section{- Long-Term Effects of Hydrocarbons*}

The major objective of the programs supporting oil and gas technology development is to identify classes and levels of petroleum hydrocarbons which do not significantly disrupt aquatic ecosystems. This knowledge will provide a strong technical rationale for specifying the degree of environmental control technology needed at production sites, i.e., at the offshore well-head and refinery. Also, this research provides data for predicting the potential ecological impact of petroleum hydrocarbons resulting from transportation spills and accidents.

Current research programs at the Marine Research Laboratory in Sequim and PNL (Richland) are designed to address a range of questions regarding the fate and effects of petroleum. The programs utilize integrated approaches and expertise in ecology, environmental physiology and analytical chemistry. Hypotheses formulated from results of either field or laboratory investigations are verified by testing in both types of systems, só that the significant variables are defined and the rates and magnitudes of effects are evaluated under natural conditions.

The framework of experimentation is designed to:

- assess the effects of petroleum hydrocarbons in the natural environment at the population and community level. This is achieved by establishing the statistical validity of sampling methods for populations and by exposing representative communities to chronic low-level contamination

- define the threshold levels of petroleum hydrocarbon contamination in seawater, above which the survival of sensitive marine organisms cannot occur

- describe the fate and effects of petroleum hydrocarbons bound to marine sediments. Phases of this large topic regard the recovery (depuration) rate of oiled sediments in the natural environment, the transport of specific components of oil from sediment to benthic organisms, and the effects of contaminated sediment on the health of individual species as well as populations settling (recruited) on the substrate.

*Includes related services contribution under joint EPA/DOE agreements. 



\title{
- Fate and Effects of Petroleum Hydrocarbons in Marine Coastal Ecosystems
}

\author{
Principal Investigators: J. R. Vanderhorst
}

The objective of these studies is to evaluate effects from petroleum hydrocarbons at the population and community levels of biological organization. Identification of potential effects in laboratory studies and measurement of actual effects of field sites are the major subtasks.

\section{Potential Effects: Laboratory Studies}

A goal in this subtask is to identify potential effects from petroleum hydrocarbons (PHC's) on population and community processes. The reseeding of populations following PHC contamination has been identified as a potentially sensitive population process. Estimation of population density, which varies greatly, is prerequisite to measurement of reseeding rate. In the current year two experimental systems have been compared for usefulness in elucidating PHC effects on natural population density. The first is a laboratory system open to reseeding by a continuous raw seawater supply. Populations on solid substrates are evaluated. The second uses in situ trays of PHC contaminated sediment. populations of animals within the sediment are evaluated. Species common to both systems were used for the comparison.

of interest is the relative amount of effort required to measure effects on population density from PHC. Figure 4.1 estimates the effort needed to measure effects on population density for two species. From 2 to 60 replicate tanks are required to detect differences in population density between. PHC-contaminated and control tanks from 90\% to $10 \%$. This estimate is for the species to which the approach is most suited (Ophiodromus pugettensis). In contrast, from 4 to nearly 400 replicate tanks are required to detect a difference of from $130 \%$ to $10 \%$ for Psephidia lordi. A risk of $10 \%$ is accepted that the differences observed may be due to change.

Figure 4.2 compares the two approaches. For this comparison a standard sensitivity $(50 \%)$ is used and a risk of $10 \%$ that the observed difference $(50 \%)$ is due to change is accepted.
The laboratory approach proved superior for polychaetes (Platynereis bicanaliculata, Ophiodromus pugettensis, and Armandia bioculata) in terms of required effort. The in situ approach was superior for bivalues (Psephidia lordi and Mysella tumida). Costs for measuring population density in either of the systems is high but feasible. For the in situ approach the overall effort can be reduced

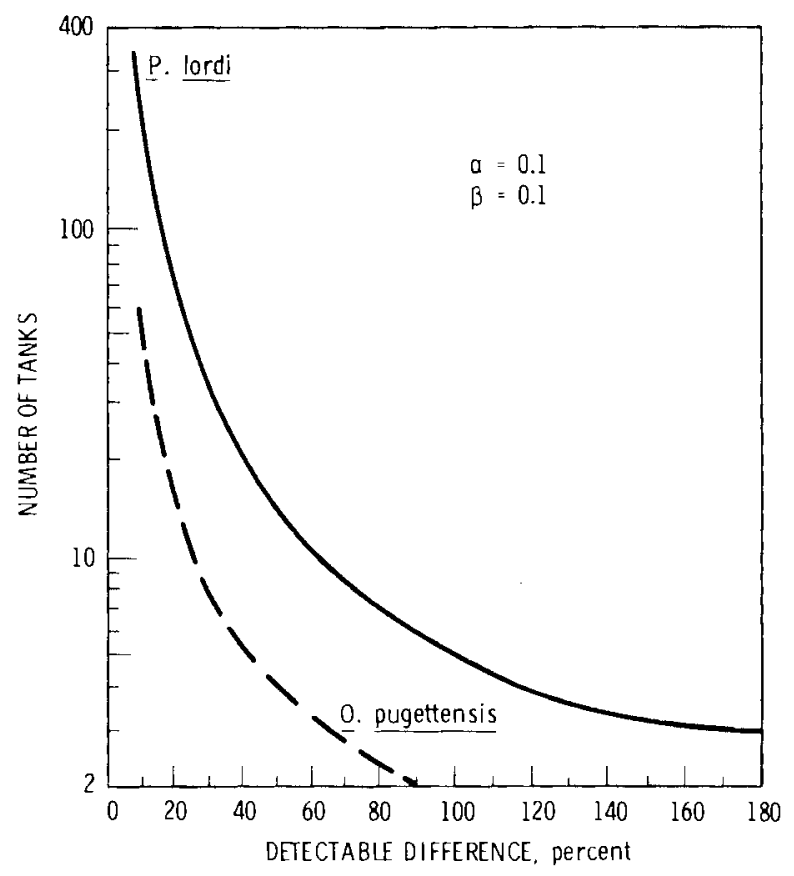

FIGURE 4.1. Number of Tanks Required to Detect Percent Differences in Treatment and Control Means for $P$ sephidia lordi and Ophiodromus pugettensis. 
by subsampling (Figure 4.2A). Subsampling effort appears to be relatively uniform between species.

Measurement of Actual Effects on Populations and Communities from $0 i 1$ and Gas Technologies

This subtask involved sampling of the intertidal zone of four sites in the north Puget Sound region. Two of these sites have high potential for contamination by PHC'S;

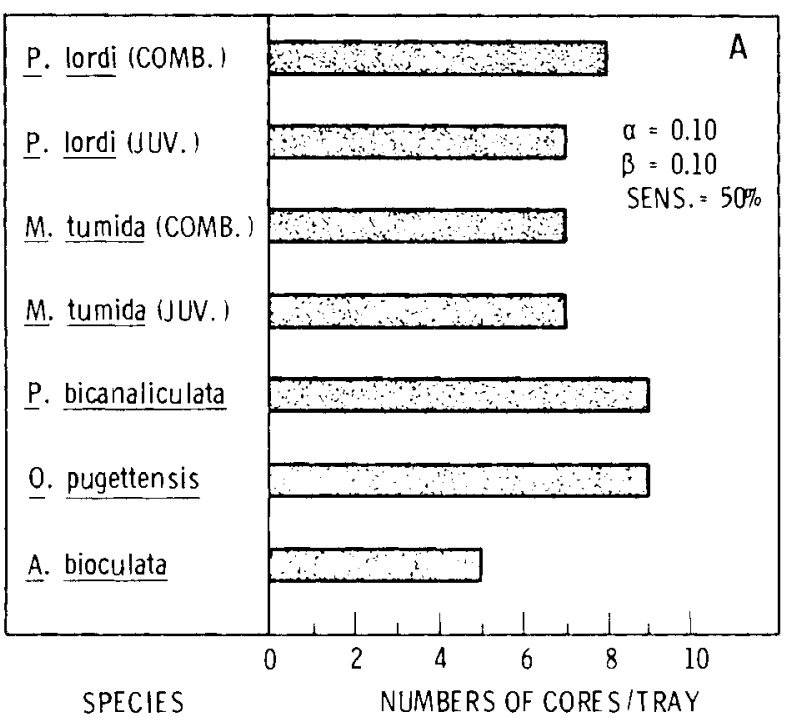

two do not. A manuscript was prepared describing the statistical sensitivity of littleneck clan density methods before the current year Vanderhorst, J. R. and Wilkinson, P., The littleneck clam (Protothaca staminea) as a tool for potential oil pol1ution assessment: Pt. 1, Density of stock; accepted for publication in Marine Environmenta? Research, November 10, 1978. The subtask was curtailed for the current year at the request of the Department of Energy.
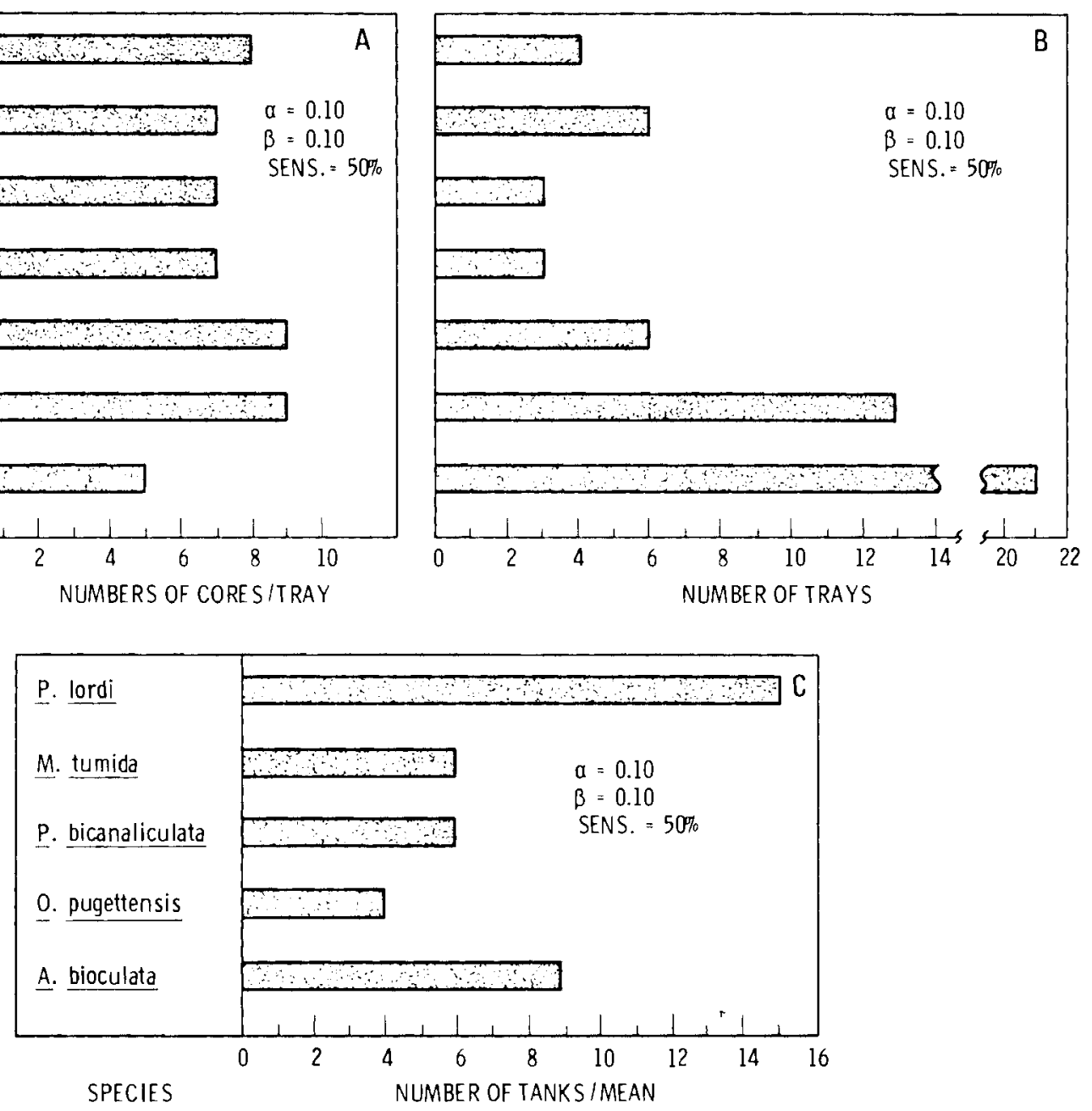

FIGURE 4.2. Comparative Sensitivity of In Situ Versus Laboratory Methods: A. Subsampling Effects, In Situ Experiment; B. Treatment Effects, In Situ Experiment; C. Laboratory Treatment Effects. 


\title{
- Long-Term Effects of Hydrocarbons on Selected Ecosystems and Associated Organisms
}

\author{
Principal Investigator: 3. W. Anderson
}

One of the major objectives of this program is to determine the responses of various marine organisms to realistic concentrations of hydrocarbons in water for different exposure periods. This information will be used in a model for assessing the effects from oil inputs ranging from short-term spill situations to chronic releases. Methods of exposure and calculations of responses are designed to provide a statistically valid means of predicting the damage of inputs to marine species.

Characterization of the Flowing Exposure System

In earlier reports we described various aspects of our quantitation and identification methods for determining the precise characteristics and levels of petroleum hydrocarbons (PHC's) contacted by test species. Over the past year we have utilized two systens: filtered and unfiltered (Table 4.1). White rearing amphipods it was necessary to construct containers which would not allow the animals to exit, and these restricted surface outflow, thus producing a thin oil film. To remove the film and eliminate buildup of oiled particulates or $0 i 1$ droplets, filters were installed which had a slight effect on specific component distribution within the exposure water. The differences observed in quantitative analyses can be explained by the selective removal of droplets (whole oil) and the enrichment of very soluble aromatics washed from the oil on the filters. Table 4.1 shows the analyses of total ojl by the infrared spectrometry (IR) hydrocarbons adsorbed to $X A D-2$ resin columns. This method is frequently used in monitoring analyses to determine the consistency of a given concentration in the delivery system.

There is rather close correlation between the $300 \mathrm{ppb}$ value in the unfiltered system by IR and the $281 \mathrm{ppb}$ determination by helium equilibration (HeEq) and gas capillary chromatography (GC) of total aromatics. This correlation is not as good for the filtered water because of higher contribution from monoaromatics, which are recovered less efficiently from the resin and are less detectable by the IR analys is technique. It is interesting to note how this rather minor modification of the system produced changes in component distributions which must be taken into account in evaluating effects on a given species. Without these extensive analyses, differences could not be detected and comparisons between responses of different species or between tine

TABLE 4.1. Concentrations of Hydrocarbons in Continuous-Flow Bioassay Apparatus as Determined by IR, Helium Equilibration, and Capillary GC Techniques. Unfiltered oil exposure tanks were sampled in May, 1978. Filtered oil exposure tanks were sampled in February, 1978. Concentrations are in $\mu \mathrm{g} / \ell$ and standard deviations are in parentheses.

Oil Concentration (IR)

Saturates $\left(C_{8}-C_{25}\right)$

Aromatics

\begin{tabular}{|c|c|c|c|}
\hline \multirow{3}{*}{$\begin{array}{l}\text { il Concentration (IR) } \\
\text { turates }\left(C_{8}-C_{25}\right)\end{array}$} & \multirow{2}{*}{$\frac{\text { Unfiltered }}{300}$} & \multicolumn{2}{|c|}{ Filtered } \\
\hline & & \multirow{2}{*}{$\begin{array}{l}320 \\
34.97\end{array}$} & \multirow{2}{*}{$\begin{array}{l}(50) \\
(3.85)\end{array}$} \\
\hline & $19.80 \quad(2.32)$ & & \\
\hline \multicolumn{4}{|l|}{ romatics } \\
\hline Benzene & $81.4 \quad(3.8)$ & 389.1 & $(92.6)$ \\
\hline Toluene & $112.6 \quad(24.1)$ & 319.1 & $(35.0)$ \\
\hline Dimethylbenzenes & $48.0 \quad(5.7)$ & 214.1 & $(19.3)$ \\
\hline Trimethylbenzenes & $16.8 \quad(1.3)$ & 55.8 & (7.5) \\
\hline$C_{4}-$ Benzenes & $5.50 \quad(0.61)$ & 18.90 & $(0.38)$ \\
\hline Naphthalene & $5.61 \quad(0.42)$ & 11.65 & $(0.41)$ \\
\hline Methylnaphthalenes & $6.56 \quad(0.56)$ & 13.39 & $(0.27)$ \\
\hline Dimethylnaphthalenes & $3.95 \quad(0.37)$ & 5.84 & $(1.04)$ \\
\hline Trimethylnaphthalenes & $2.0^{(\mathrm{a})}$ & \multicolumn{2}{|r|}{$2.0^{(\mathrm{a})}$} \\
\hline Phenanthrene & $0.18 \quad(0.02)$ & 0.35 & $(0.07)$ \\
\hline omatics Total & 282.6 & \multicolumn{2}{|c|}{1031.1} \\
\hline
\end{tabular}

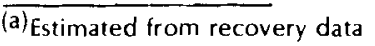

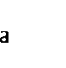


same species in other systems could not be made.

Analytical Procedures to Ensure Internal Consistency

In the past year, an analytical procedure has been developed for the quantitation of saturate and aromatic hydrocarbons in the tissue of marine organisms. The method is directly applicable to the determination of concentrations of hydrocarbons in organisins exposed to chronic or acute hydrocarbon levels in the continuous-flow bioassay system, and in organisms exposed to oilcontaminated sediments in field and laboratory studies. The method is being expanded to include several tissue types. It has been used in two intercomparisons of data produced at Battelle's Richland and Sequim laboratories to ensure accuracy, precision and internal consistency.

The results of the second hydrocarbon tissue intercomparison exercise are shown in
Table 4.2. Hydrocarbon concentrations reported in column 1 of Table 4.2 by the Richland laboratory are corrected for percent recovery based on correction factors derived from quantitatively determining the amount lost of known amounts of each of the individual hydrocarbons amended into uncontaminated tissue. These results are compared to results obtained using a simplified calibration where only three pre-selected hydrocarbons are used for correcting the raw data for recovery.

In the second method, saturate hydrocarbons are corrected based on the recovery of 2-methylhexadecane. Diaromatic hydrocarbons and phenanthrene are corrected on the basis of biphenyl and the methylphenanthrenes on the basis of pyrene. Most values reported in Table 4.2 are within $20 \%$ of the actual amounts amended and, therefore, better than the values reported in the first two columns, indicating that simplification of the recovery portion of the procedure has not reduced accuracy or

TABLE 4.2. Concentrations of Saturate and Aromatic Hydrocarbons in Amended Clam Tissue as Measured by Gas Chromatography. Concentrations are in parts per million (ppm).

\begin{tabular}{|c|c|c|c|}
\hline Compound & $\begin{array}{l}\text { Richland, } \\
\% \text { recovered }\end{array}$ & $\begin{array}{c}\text { Sequim, } \\
\% \text { recovered }\end{array}$ & $\begin{array}{c}\text { Corrected by Uses of Three } \\
\text { Specific Hydrocarbons, } \\
\% \text { recovered }\end{array}$ \\
\hline $\mathrm{nC}_{12}$ & (112) & (52) & 74 \\
\hline $\mathrm{nC}_{14}$ & (102) & $(60)$ & 86 \\
\hline $\mathrm{nC}_{15}$ & (99) & $(68)$ & 95 \\
\hline $\mathrm{nC}_{16}$ & (109) & $(75)$ & 105 \\
\hline $\mathrm{nC}_{17}$ & (111) & (84) & 116 \\
\hline $\mathrm{nC}_{22}$ & (159) & (93) & 148 \\
\hline $\mathrm{nC}_{24}$ & (150) & (76) & 126 \\
\hline Naphthalene & (129) & $(80)$ & 91 \\
\hline $2-M^{(a)}$ & (118) & (89) & 98 \\
\hline $1-M N$ & $(120)$ & (94) & 107 \\
\hline 2,6-DMN(b) & (108) & $(151)$ & 106 \\
\hline 1,3-DMN & (125) & $(148)$ & 112 \\
\hline 2,3-DMN & (116) & (111) & 114 \\
\hline $2,3,6-\mathrm{TMN}(\mathrm{C})$ & (104) & (117) & 114 \\
\hline Phenanthrene & (137) & (69) & $133(104)^{(e)}$ \\
\hline 1-MP(d) & (113) & (69) & 117 \\
\hline
\end{tabular}

(a) $\mathrm{MN}=$ methylnaphthalene

(b) $\mathrm{DMN}=$ dimethylnaphthaiene

(c) TMN = trimethylnaphthalene

(d) $\mathrm{MP}=$ methylphenanthrene

(e) Value in parentheses are based on pyrene recovery factor. 
precision. Hydrocarbon concentrations reported by the Richland laboratory, with the exception of one compound, are greater than $100 \%$ of actual amounts amended to tissue samples. The hydrocarbon concentrations reported in column 2 by the Sequim laboratory show amounts both above and below the actual anounts amended to the tissue. Both laboratories have agreed to use the simplified metinod where only the three preselected hydrocarbons are used for calibration, which should ensure the inner consistency of data produced by both laboratories.

By using the method, we are participating in a national analytical intercompar $i-$ son study conducted by the National Bureau of Standards for the Bureau of Land Management. Such exercises are being conducted to devise methods of standardization for hydrocarbon analyses such that analytical results from environmental studies of different national laboratories can be better intercompared. Analytical methods are currently being developed to ensure the accuracy, precision and internal consistency of experimental data on the analysis of hydrocarbons in sediments. The methods will be tested employing interlaboratory intercomparison studies similar to those described for tissue analyses.
Uptake of Hydrocarbons from the Flowing System

For several years, studies have been conducted on the extent of hydrocarbon accumulation and the duration of retention in the tissues of bivalve mollusks. Early reports indicated that these compounds were retained in the tissues indefinitely, thus removing the valuable resource from the market and the consumer. However, in later studies, it has been shown that clams and oysters cleansed themselves of the contamination in one to three months, but there was some indication that a small residue was retained. Reports from field sampling also suggested the presence of a "stable pool" of hydrocarbon contamination detected in animals that had been exposed over long time intervals. The apparent conflict between the various conclusions of several investigators was important to address because it concerned the contamination of commercially valuable seafood products.

Using our we11-characterized hydrocarbon delivery system, we investigated the problem in detail. Table 4.3 illustrates the findings of showing the specific component analys is of the exposure water and the tissues of oysters exposed over a period of nine

TABLE 4.3. Glass-Capillary Gas Chromatography Analyses of Exposure Water and Oysters Exposed for One to Nine Weeks. Mean water values are derived from three replicates and oyster data from six replicates at each time interval (standard deviations in parentheses).

\begin{tabular}{|c|c|c|c|c|}
\hline \multirow[b]{2}{*}{ Hydrocarbons } & \multirow{2}{*}{$\begin{array}{l}\text { Water, } \\
\text { ppb }\end{array}$} & \multicolumn{3}{|c|}{ Oysters, ppm } \\
\hline & & 1 Week & 5 Weeks & 9 Weeks \\
\hline $\begin{array}{l}\text { Total n-alkanes } \\
\left(\mathrm{C}_{12}-\mathrm{C}_{28}\right)\end{array}$ & $8.5(0.3)$ & $0.4(0.3)$ & $<0.3$ & $<0.3$ \\
\hline Naphthalene & $4.3(0.3)$ & $0.8(0.4)$ & $0.3(0.3)$ & $2.0(1.7)$ \\
\hline $2-M N$ & $4.7(0.5)$ & $2.6(1.0)$ & $1.4(1.7)$ & $8.6(3.2)$ \\
\hline $1-M N$ & $3.7(0.4)$ & $2.0(0.8)$ & $1.4(2.0)$ & $7.2(3.0)$ \\
\hline 1 ethyl + 2 ethyl $N$ & $1.0(0.1)$ & $0.8(0.5)$ & $0.7(0.8)$ & $5.7(2.1)$ \\
\hline $2,6+2,7 \mathrm{DMN}$ & $0.7(0.2)$ & $1.2(0.5)$ & $0.7(0.6)$ & $6.6(2.3)$ \\
\hline $1,3+1,6 \mathrm{DMN}$ & $1.8(0.3)$ & $1.9(0.7)$ & $1.2(1.0)$ & $10.3(4.1)$ \\
\hline $1,7 \mathrm{DMN}$ & $1.9(0.3)$ & $2.2(0.9)$ & $1.0(0.7)$ & $7.9(5.4)$ \\
\hline $1,4+2,3+1,5 \mathrm{DMN}$ & $1.2(0.1)$ & $1.7(0.8)$ & $0.5(0.6)$ & $8.4(2.9)$ \\
\hline 1,2 DMN & $0.5(0.1)$ & $0.6(0.3)$ & $0.3(0.6)$ & $5.9(3.1)$ \\
\hline Phenanthrene & $0.6(0.1)$ & $0.7(0.4)$ & $0.3(0.4)$ & $11.9(6.9)$ \\
\hline$M P(a)$ & $0.9(0.1)$ & $1.7(0.7)$ & $0.9(0.7)$ & (c) \\
\hline $\mathrm{DMP}(\mathrm{b})$ & $0.3(0.1)$ & $0.8(0.4)$ & $0.6(0.5)$ & (c) \\
\hline Total Aromatics & $21.6(2.0)$ & $16.6(6.4)$ & $9.2(7.4)$ & $74.7(22.8)$ \\
\hline Total Hydrocarbons & $31 \mathrm{ppb}$ & 17 ppm & 9 ppm & 75 ppm \\
\hline
\end{tabular}

\footnotetext{
(a) $\mathrm{MP}=$ methylphenanthrenes

(b) DMP = dimethylphenanthrenes

(c) Analyses are not yet completed.
} 
weeks. It should be noted that the concentrations of total hydrocarbons in the delivery water was 31 parts per billion (ppb), while the tissues of the oysters contained 9 to 75 parts per million (ppm) at the three sampling intervals. As is normal for uptake by bivalves, the content of individuals varied such that the concentrations at one and five weeks are not significantly different (standard deviations $40-80 \%$ of the mean). The concentration at nine weeks is higher than the oarlier levels, and the $75 \mathrm{ppm}$ represents a magnification factor in the tissues of 2400 times that in the water. As has been observed in other studies, the naphthalenes and phenanthrenes were all accumulated in the tissues.

A most significant aspect of our findings regards the levels of hydrocarbons in oysters transferred from the exposure system at one, five, and nine weeks to clean flowing seawater for three weeks (six at each interval). None of these organisms exhibited detectable levels of contamination, which would be 0.3 ppm total n-alkanes, $0.02 \mathrm{ppm}$ individual aromatics and $0.25 \mathrm{ppm}$ total aromatics. Since there was no evidence on long-term retention, regardless of the exposure period, it must be concluded that there is no "stable compartment" in the tissues which would produce long-term contaminaton. It is likely that field and laboratory samples which suggested longer retention (analyzed by other researchers) were not analyzed by the best possible means, or were not allowed to depurate the contamination in a flowing and truly clean seawater system.

While very recent information indicates that hydrocarbons degrading enzyme systems may be present in bivalves, their level of activity is probably 100 times lower than those of fish and some crustaceans. Therefore, the release of hydrocarbons from the oysters, described above, was probably the result of partitioning from tissue back to the water. In crustaceans depuration of contaminants would probably be faster, and uptake would probably show saturation at some time. During the extensive studies of the benthic amphipod Anonyx laticoxae we conducted several hydrocarbon uptake experiments for correlation with toxic and sublethal effects studies. During a short-term exposure of $96 \mathrm{hr}$ at a concentration of $0.5 \mathrm{ppm}$ total hydrocarbons or 31 ppb total naphthalenes, we found that the amphipods accumulated a mean of $1.92 \mathrm{ppm}( \pm 0.7)$ specific naphthalenes, and a one-week depuration in clean water resulted in complete release of contaminants $(<0.02 \mathrm{ppm})$. A second test at the same exposure concentration resulted in contamination of specific naphthalenes, as shown in Figure 4.3. Using the ultraviolet technique for naphthalenes analysis, it was observed that the tissue content of the parent

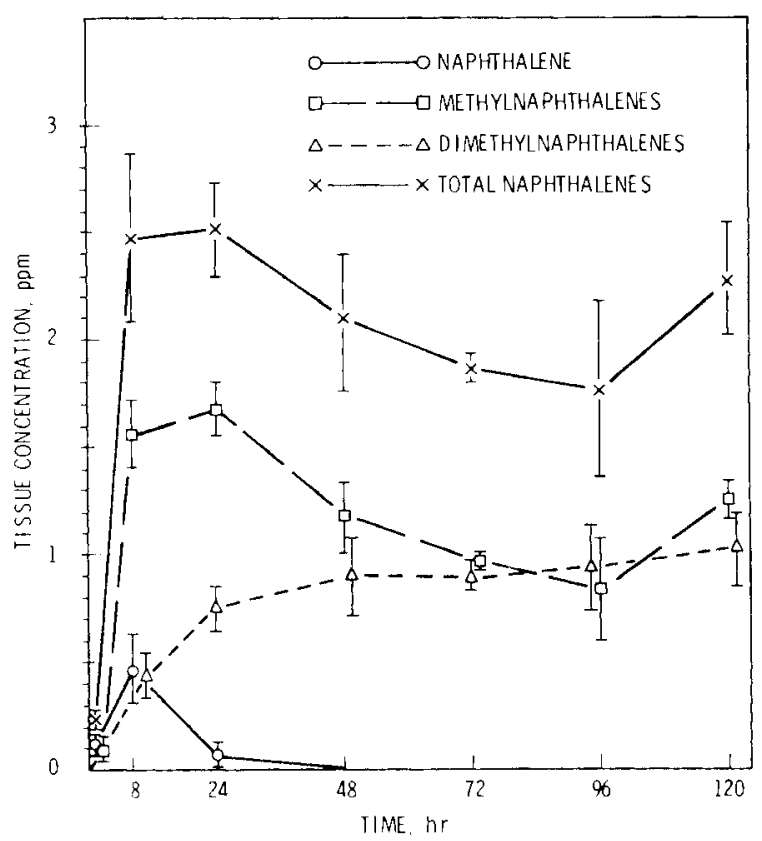

FIGURE 4.3. Ultraviolet Tissue Analysis of Adult Amphipods Exposed to Hydrocarbons in a Flowing System. Data points are the mean of three replicate samples and the confidence limits are standard errors, $\mathrm{SE}=\frac{\mathrm{SD}}{\sqrt{\mathrm{N}}}$.

compound (napinthalene) reached a peak at 8 $\mathrm{hr}$, then dropped to nondetectable at two days. Both the methyl(MN) - and dimethylnaphthalenes (DMN) increased during the first ?4 $\mathrm{hr}$ and at later intervals the methylisomers decreased, while the OMN increased over the five-day period. The total naphthalene values, composed of the alkylated forms, tended to level off by the end of the exposure. In the final test on accumulation, tissues from six animals (per sample) were analyzed by gas chromatography after exposure periods up to 27 days (Table 4.4). The total values are higher than those shown in Figure 4.3 , which is probably due to more exact analytical techniques. There is relatively little accumulation of naphthalene (as seen in Figure 4.3), while tissue levels of the alkyl-naphthalenes increase to a peak at seven days and remain relatively stable thereafter. The mean level of contamination from day 7 to 27 was $20 \pm 5$ ppm total naphthalenes, which represents a thousandfold magnification over concentrations in the water $(0.37 \mathrm{ppm}$ total hydrocarbons and $22 \mathrm{ppb}$ naphthalenes).

It is relatively easy to compare these two uptake and release studies as the exposure system and concentrations were approximately equal. Oysters accumulated 10 to $15 \mathrm{ppm}$ naphthalenes in 7 to 35 days, but by 63 days the contamination was at $74 \mathrm{ppm}$. It is not known exactly when depuration hy oysters was complete, but all earlier studies suggest it would take at least the three weeks used in 
TABLE 4.4. Gas Chromatography Analysis of Amphipods Exposed in the Flowing System for Periods up to 27 Days (sample sizes between 0.8 and $2 \mathrm{~g}$ for six animals).

\begin{tabular}{|c|c|c|c|c|c|c|c|c|c|c|}
\hline \multirow[b]{2}{*}{ Hydrocarbons, ppm } & \multicolumn{10}{|c|}{ Exposure Time } \\
\hline & $8 \mathrm{hrs}$ & $24 \mathrm{hrs}$ & 4 days & 7 days & 10 days & 15 days & 19 days & 22 days & 27 days & Control \\
\hline Naphthalene & 0.74 & 1.24 & 0.62 & 1.94 & 1.14 & 1.40 & 0.71 & 0.85 & 0.50 & $<0.04$ \\
\hline 1-Methylnaphthalene & 1.13 & 2.93 & 2.06 & 5.39 & 3.75 & 3.79 & 1.70 & 3.42 & 1.96 & $<0.04$ \\
\hline 2-Methylnaphthalene & 0.89 & 2.24 & 1.73 & 4.35 & 3.23 & 3.24 & 1.52 & 3.36 & 1.90 & $<0.04$ \\
\hline (1-Ethyl + 2 Ethyl) & 0.21 & 0.52 & 0.48 & 1.53 & 1.46 & 1.63 & 0.71 & 1.65 & 1.29 & $<0.04$ \\
\hline Total Methyl + Ethyl-naphthalenes & 2.23 & 5.69 & 4.27 & 11.27 & 8.44 & 8.66 & 3.93 & 8.43 & 5.15 & $<0.04$ \\
\hline \multicolumn{11}{|l|}{ Dimethylnaphthalenes } \\
\hline $2,6+2,7$ Dimethylnaphthalenes & 0.45 & 0.72 & 0.81 & 1.36 & 1.94 & 2.24 & 1.10 & 2.27 & 1.84 & $<0.04$ \\
\hline 1,3 + 1,6 Dimethylnaphthalenes & 0.44 & 1.55 & 1.84 & 3.87 & 3.80 & 4.73 & 1.93 & 3.91 & 2.65 & $<0.04$ \\
\hline 1,7 Dimethylnaphthalene & $<0.04$ & $<0.04$ & $<0.05$ & $<0.02$ & $<0.02$ & $<0.02$ & $<0.03$ & $<0.02$ & $<0.02$ & $<0.04$ \\
\hline $1,4+2,3+1,5$ Dimethylnaphthalenes & 0.28 & 0.83 & 1.04 & 2.59 & 2.63 & 2.88 & 1.45 & 2.84 & 2.46 & $<0.04$ \\
\hline 1,2 Dimethylnaphthalenes & 0.10 & 0.32 & 0.44 & 0.95 & 0.95 & 1.11 & 0.56 & 1.05 & 1.01 & $<0.04$ \\
\hline Total Dimethylnaphthalenes & 1.48 & 3.94 & 4.61 & 10.30 & 10.78 & 12.59 & 5.75 & 11.72 & 9.25 & $<0.04$ \\
\hline Total Naphthalenes & 4.66 & 11.39 & 9.98 & 25.04 & 21.82 & 24.28 & 11.10 & 22.65 & 16.19 & $<0.04$ \\
\hline
\end{tabular}

this study. The uptake exhibited by amphipods was quite rapid, reaching maximal concentrations between four and seven days at levels somewhat higher than oysters at 35 days, but about one-third the 63-day oyster values. There was no indication of a saturation level being reached by oysters (this is confirmed in other reports), while amphipods maintained quite constant values for 20 days. Methyl - and dimethylnaphthalenes are the primary contaminants of the exposed amphipods, and earlier studies with bivalues have also shown that these are retained longer than the parent compound.

These data create an accurate picture of the rates and magnitude of hydrocarbon exchange bețeen marine organisms in a chronically contaminated environment. It is possible to predict the extent and duration of contamination in rather different organisms. The results are consistent with our knowledge of the metabolic capabilities of these two species and what is known about the partitioning coefficients of these compounds. The higher degradation capacity of amphipods produces a stable level of contamination, while bivalves continue to accumulate the material. The order of hydrocarbon release is naphthalene $\rightarrow \mathrm{MN} \rightarrow \mathrm{DMN} \rightarrow \mathrm{P} \rightarrow \mathrm{MP} \rightarrow \mathrm{DMP}$, which would be predicted from the relative solubilities of these compounds in lipids and water. Higher molecular weight aromatics tend to be more firmly bound to tissue lipids and less likely to exchange with the surrounding water.
Toxicity Indices of Selected Marine Species

Since study on growth and reproduction of mysids and amphipods was very time-consuming and not as productive as hoped, we have changed our objectives for this task as discussed in the last semi-annual report. We have been very active in producing "toxicity indices" to evaluate the relative resistance of various species and in expressing these data in a form that will be most useful for predicting impacts from oil spills and chronic exposure. Table 4.5 summarizes our findings from exposure concentrations and periods which produced $50 \%$ mortality (LC50). Only the highest concentration tested $(2.9 \mathrm{ppm}$ total hydrocarbons) produced $50 \%$ mortality for the chum salmon (Oncorhyncus keta). This occurred at 3 days of exposure. The mysids tested at several concentrations lower than this exhibited $50 \%$ mortality in $12 \mathrm{hr}$ to seven days. LC50 values were also determined for grass shrimp (Hippolyte clarki) coonstriped shrimp (Pandalus danae) and sand lance (Ammodytes hexapterus) (Table 4.5). By taking the product of the LC50 concentration and the time to $50 \%$ mortality, we have generated values referred to as "toxicity indices," which have as units ppm-days. From about 1? hr to six or seven days the values for a given species remain relatively constant, but by nine days or so, the index often increases sharply (grass shrimp, Table 4.5). This rise in the level required to produce mortality on prolonged exposure probably represents accommodation of the species to 
TABLE 4.5. Summary of Exposures Producing LC50 Values and Calculated Toxicity Indices.

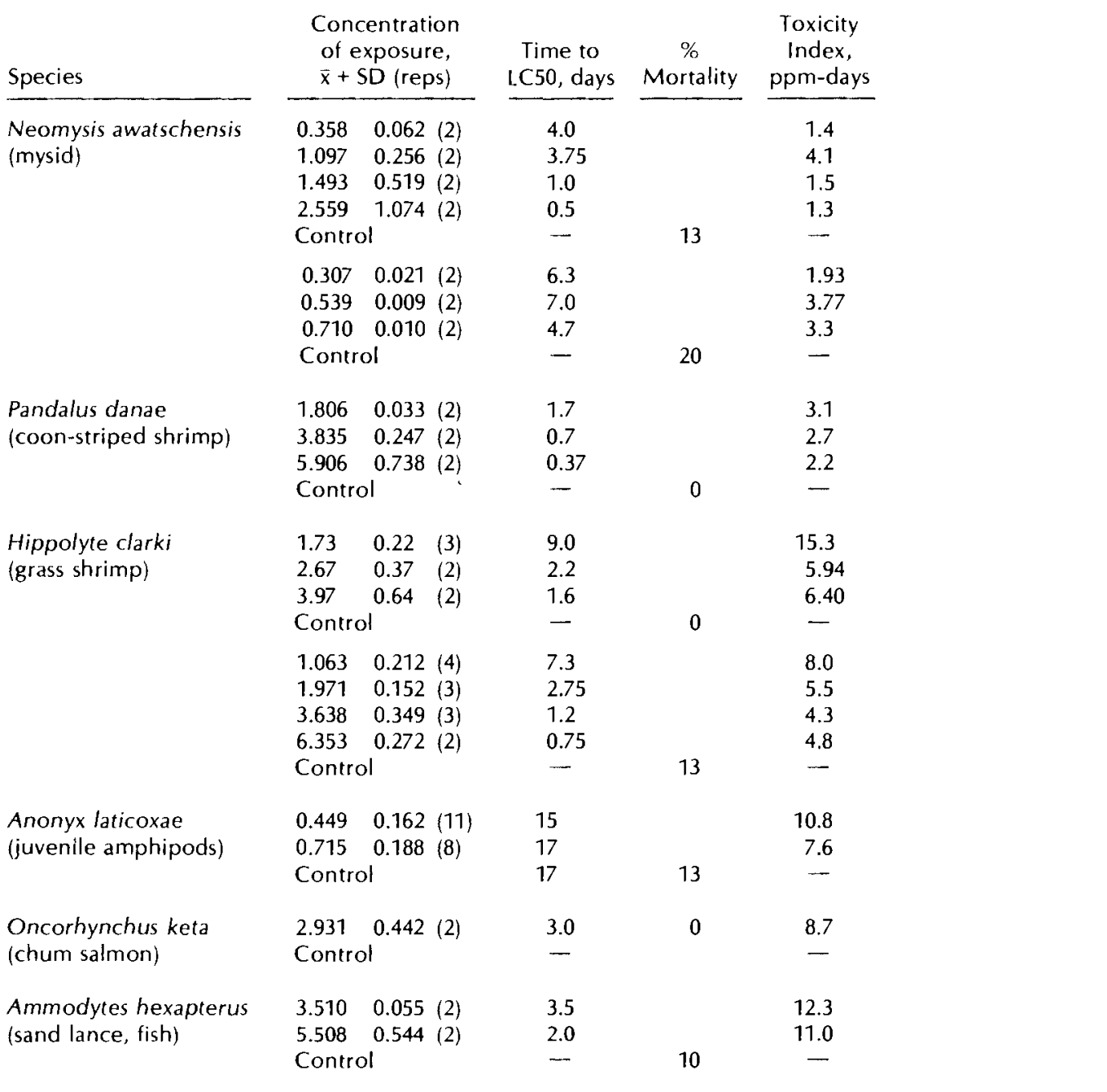

hydrocarbons, mediated by enzyme induction. We will probably limit the calculation of indices to data produced in approximately one week, but the later phases of exposure are also interesting as they provide evidence of resistance induction (Ross $i$ and Anderson, 1978).

It should be noted in Table 4.5 that the tentative ranking of these species from most to least resistant to hydrocarbons is as follows: sand lance $\rightarrow$ grass shrimp $\rightarrow$ coon-striped shrimp $\rightarrow$ mysids. The indices ranged from 12 to $1.3 \mathrm{ppm}$-days for these five species, exposed in exactly the same manner to precisely the same hydrocarbon mixture. An even greater range would be shown if we were to include the shore crab (Hemigraphsus sp.) which tolerated $2.6 \mathrm{ppm}$ for 23 days with no mortality. This indicates the extreme tolerance of these crabs to oil, which might be the result of low water permeability and/or high activity of detoxification enzymes. Other data provide a view of possible threshold levels of hydrocarbons for the various species. Percent mortalities observed between 0 and 3 after several days of exposure would tend to indicate that organisms will be capable of tolerating a given concentration for long or indefinite periods of time. For chum salmon, the concentration ranged from 0.4 to $1.0 \mathrm{ppm}$ and the values for both coon-striped and grass shrimp fell within this range. The most sensitive species ( $N$. awatschensis) still exhibited $33 \%$ mortality at $0.15 \mathrm{ppm}$, showing again that it is indeed the most sensitive species.

In a first attempt to evaluate the predictive value of these data on toxicity indices and to test the statistical significance of the findings, the data from mysids and grass 
shrimp were analyzed. When Loglo of time in days is regressed on Log10 of exposure concentration (ppin total hydrocarbons) the results shown in Figures 4.4 and 4.5 are obtained.

The null hypothesis Ho: $\alpha^{2}=\alpha i^{2}$ (where $i$ represent the variances of the slopes of the two regression lines) was tested. An $F$ $=1.08$ indicated no significant difference between variance estimates $(p>0.25)$.

The null hypothesis $\mathrm{Ho}_{0}: B_{1}=B_{2}$ (where $B_{i}$ represent the slopes of the two regression lines) was tested. The following analysis of variance table resultod.

\begin{tabular}{lrccc} 
& DF & \multicolumn{1}{c}{ SS } & \multicolumn{1}{c}{ MS } & F* \\
Between Slopes & 1 & 0.01985 & 0.01935 & 0.5545 \\
Within Slopes & 10 & 0.3579 & 0.03579 &
\end{tabular}

The $F-0.5545$ indicated no significant difference between slopes ( $p 0.25$ ).

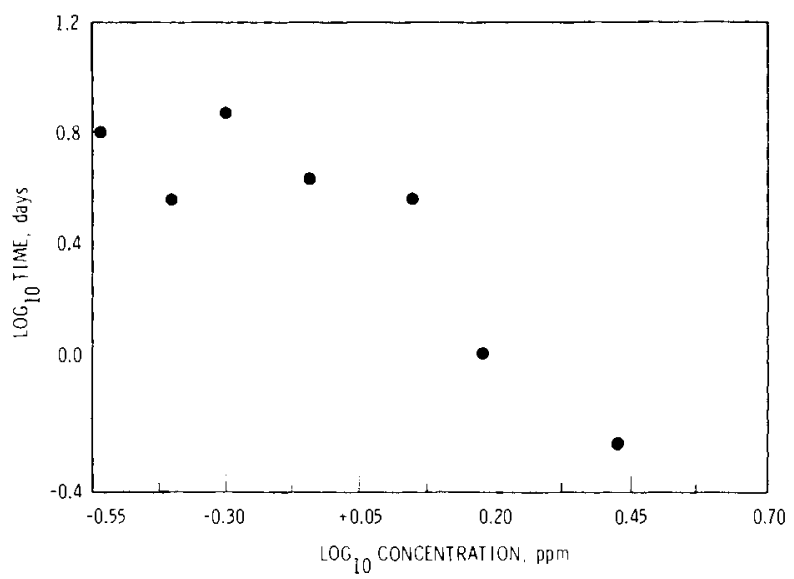

THE REGRESSION EOUATION IS $Y-0333+1-1.1 k 1 X 1$

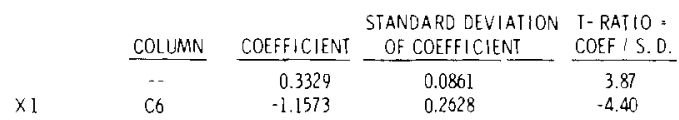

THE STANDARD DEVIATION OF Y ABOUT REGRESSION LINE IS

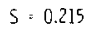

WITH $17-21=5$ DEG REES OF FREEDOM

R-SQUARED $=79.5 \%$

R-SQUJARED $=75.4 \%$. ADJUSTED FOR D.F.

ANALYSIS OF VARIANCE

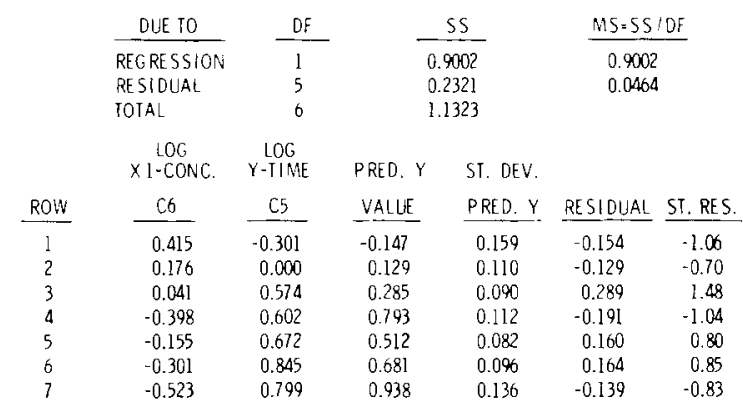

FIGURE 4.4. Regression of Log Exposure Time Versus Log Concentration for Neomysis awatschensis.
The null hypothesis that the regression lines coincide, Ho: $E(d)=0$ (where $d$ is the horizontal distance between the lines), was then tested. A test $(t=-4.402)$ indicated a highly significant $(p<0.01)$ difference in the height of the regression lines.

Pooling information from the two regressions yields a common slope bc $=-1.25718$. The regression equations then become:

$$
\text { Anima } 1 \# 1 L Y=-1.26718 \times L+0.3329
$$

Animal \#? LY $=-1.26718 \times L+1.0045$

where $L X=\log 10$ concentration and I_Y - Log10 time.

Using anti-logs the regression equations may he rewritten:

$$
\begin{aligned}
& \text { Animal \#1 } X^{1.26718} Y=2.1523 \\
& \text { Animal } \# 2 X^{1.25718} Y=10.1055
\end{aligned}
$$

where $X=$ concentration in ppm and $Y=$ time to LC50 in days.

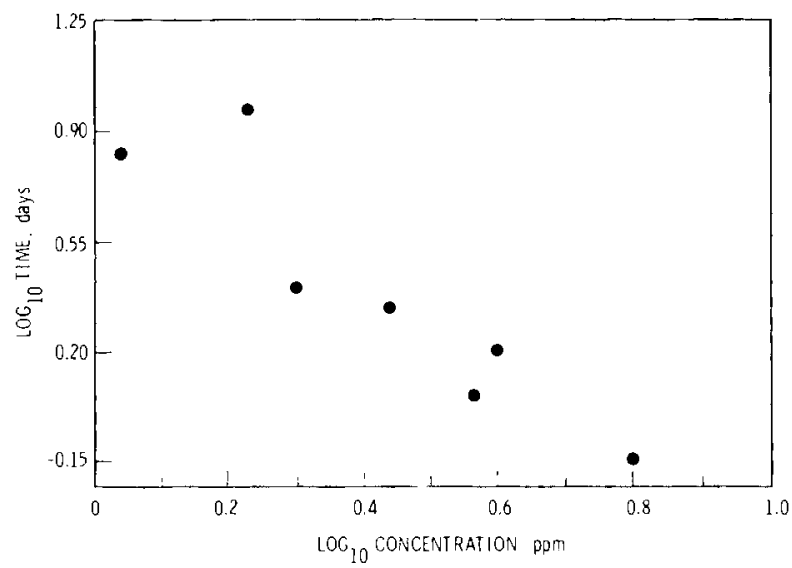

IHE REGRESSION EOUATION IS Y $-1.0+1-1.44, X]$

$$
\begin{aligned}
& \text { SIANDARD DEVIATION T-RATIO : }
\end{aligned}
$$

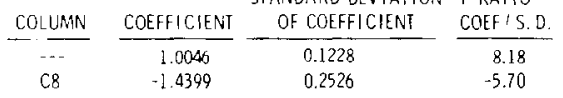

THE STANDARO DEVIATION OF Y ABOUT REGRESSION LINE IS

$S=0.159$

WITH $\{7-2\}=5$ DEGREES OF FREEDON

$R$ - SQUARED : $86.7 \%$

R-SQUAREO $=84.0 \%$, ADJUSTED FOR D.F.

ANALYSIS OF VARIANCE

$$
\begin{aligned}
& \text { DUE TO } \\
& \text { REG RESSION } \\
& \text { RE SIDUAL } \\
& \text { TOTAL }
\end{aligned}
$$$$
\begin{gathered}
\text { DF } \\
\hline 1 \\
5 \\
6 \\
\text { LOG }
\end{gathered}
$$

\begin{tabular}{|c|c|c|c|c|}
\hline $\mathrm{C} 7$ & VALUE & PRED. Y & RESIDUAL & ST. RES. \\
\hline 0.204 & 0.138 & 0.075 & 0.066 & 0.47 \\
\hline 0.342 & 0.384 & 0.060 & $-0.04 \mathrm{~L}$ & -0.28 \\
\hline 0.954 & 0.673 & 0.077 & 0.281 & 2.03 \\
\hline 0.125 & -0.156 & 0.114 & 0.031 & 0.28 \\
\hline 0.079 & 0.204 & 0.069 & -0.124 & -0.87 \\
\hline 0.439 & 0.571 & 0.068 & -0.132 & -0.92 \\
\hline 1.809 & 0.945 & 0114 & -0.082 & \\
\hline
\end{tabular}$$
\begin{array}{cc}
\operatorname{LOG} & \text { LOG } \\
\times 1-\text { CONC. } & Y-T I M E
\end{array}
$$

0.
0.125
0.943
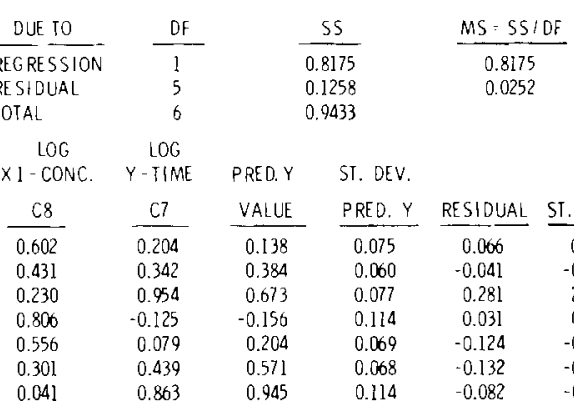

FIGURE 4.5. Regression of Log Exposure Time Versus Log Concentration for Hippolyte clarki. 
Thus, preliminary results seem to indicate that the relationship between concentration of total hydrocarbon and time to LC50 may be represented as:

$$
x 1.26 \quad y=C
$$

with $C$ varying from species to species. In these examples mysids (Animal \#1) were about five times more sensitive than grass shrimp. These studies are continuing because we need more data on the present species, taken at various periods of the vear, and data on other species. The analytical and statistical approach is being constantly improved. To our knowledge, this is the only approach which can be used predictively, since it takes into account varying periods of exposure and changing concentrations. When a firm data base has been compiled, we should be in a position to estimate the damage to a range of species from various types of actual hydrocarbons inputs.

The other two phases of our research relate to field studies with oiled sediment exposures. Much of the information reported by $V$ anderhorst (above) was generated from research on our recruitment task. The first report of these studies included an extensive study of the depuration of $0 i 1$ from sediments in the field and a preliminary report on recruited organisms (Anderson et al., 1978). $\checkmark$ anderhorst et al. then discussed the data in a framework of valid statistical design of future field investigations (Vanderhorst,
1. Q., Anderson, J. W., Wilkinson, P. and Woodruff, D. I.., in press. Estimation of effects from oil on intertidal populations: Experimental perturbation versus natural variation. Presented at the Conference on Assessment of Ecological !mpacts of 0il Spills, Proceedings to be published by the American Institute of Biological Sciences).

The third task of this program concerns the transport of hydrocarbons from oiled sediments and their effects on marine organisms. As discussed in Section 11.0, the program funded by NOAA/BIM has been complementary to this DOE project, since a given field experinent may incorporate the manpower and expertise of others to produce a greater range of biological and chemical Findings.

\section{Literature Cited}

Anderson, J. W., Riley, R. G. and Bean, R. M. 1973. Recruitment of benthic animals as a function of petroleum hydrocarbon concentrations in the sediment. Journal of the Fisheries Research Board of Canada 35: 775-790.

Rossi, S. S. and Anderson, J. W. 1973. Petroleum hydrocarbons resistance in the marine worn Neanthes arenaceodentata (Polychaeta: Annelida), induced by chronic exposure to No.? fuel oil. Bulletin of Environmental Contamination and Toxicology 20:513-521. 
5.0

Nuclear Waste:

Fission 


\section{NUCLEAR WASTES: FISSION}

- Transuranic Behavior in Soil and Plants

- Quantitative Aspects of Plutonium Field Studies

- Analogs for Transuranic Chemistry

- Transuranic Weathering in Plants

- Radioecology of Nuclear Fuel Cycle

- Environmental Behavior and Effects of Technetium-99 and Jodine-129

One of the highest priorities in the continued development and use of fission as a source of energy is the resolution of questions about the long-term fate and ultimate effects of long-lived radionuclides in the biosphere. This long-term behavior generally cannot be confidently inferred from the short-lived isotopes. The individual studies described in this section range from basic investigations of the behavior and effects of long-lived nuclides at the chemical and cellular level to ecosystems studies which describe inventory, transport, and effects in waste management areas. The investigations and reports listed in this section are designed to differentiate and measure certain processes affecting the biological availability of the radioelements. The specific applications of this and other information to nuclear fuel reprocessing and waste management sites will be found in Section 8. Materials of particular concern in connection with Nuclear Fusion, e.g., ${ }^{3} \mathrm{H}$, are covered in Section 6.

In terrestrial studies, investigations of transuranics in soils and plants have demonstrated the importance of valence state, complexation, competing elements, microbial processes, migration down the soil profile, and weathering cycles in governing transuranic, availability of ${ }^{129} \mathrm{I}$ and ${ }^{99} \mathrm{Tc}$ to plants and, in the case of plutonium, to the consuming animals. In the latter case, it was demonstrated for the first time that ingestion of plant tissues containing plutonium may result in greater transfer across the gut compared to gavaging animals with inorganic plutonium solutions. This underscores the importance of detailed studies of soil, plant and animal factors influencing uptake by the ingestion pathway. The importance of the ingestion pathway was also seen in studies of foliar interception of airborne transuranic elements in which plants were seen to effectively intercept and retain plutonium in particles in the respiratory size range and significant quantities of intercepted plutonium were transported to roots and seeds. Similar studies on the terrestrial ingestion pathway have been initiated with other actinides including uranium, americium, curium and neptunium. 
Radioecological field studies at PNL were directed toward establishment of pertinent ingestion pathways and exposure levels through description of habitat types, population densities, and, in several instances, dosimetry, for major insects, reptiles, birds, and mammalian species. These studies were extended to agricultural ecosystems through definition of the uptake of long-lived nuclides and digestibility in cattle of several forage species. In studies on a pond ecosystem at the nuclear fuel reprocessing plant, plutonium and americium uptake rates were studied for major biotic components including organic floc, algae, fish and ducks. The results indicated that assimilation of transuranics by the biota and export from the pond system were low compared to the total inventory.

Field inventory studies have provided the bases for appropriate environmental sampling, and in conjunction with basic studies of plutonium behavior in soils and plants, have resulted in the development of reliable statistical procedures for estimating the concentrations of transuranics in soils. Decisions as to need for land decontamination in former nuclear detonation and waste management areas will be based on this inventory.

The approaches developed in terrestrial and freshwater studies were recently extended to studies of the marine environment. The marine environment may represent an ultimate repository for the mobile forms of transuranic elements and results indicate that geochemical and biochemical factors may influence transuranic mobility and availability to biota. Investigations have provided a basis for description of dispersion mechanisms on the sea floor of transuranics arising from nuclear detonations and a bomber crash. In addition to physical dispersal, biochemical factors may influence transuranic speciation and mobilization resulting in substantial changes in plutonium availability as a function of ocean depth.

This is a comprehensive program, encompassing basic, as well as descriptive studies on the behavior and effects of the major long-lived radionuclides. It should provide a better integrated picture of the extent of engineering sophistication required in the nuclear fuel cycle to minimize risks associated with this important energy source. 


\title{
- Transuranic Behavior in Soils and Plants
}

\author{
Principal Investigators: R. E. Wildung, T. R. Garland \\ K. M. McFadden, J. E. Rogers, D. A. Cataldo, and M. Sullivan
}

The principal objectives of these investigations are to determine 1) the potential for alteration of transuranic solubility through formation of transuranic complexes in soil and the role of the soil microflora in this process, 2) the extent of uptake and translocation by plants and the sites of plant deposition of transuranics or their complexes, 3) the bond types and chemical forms of transuranics of their metabolites in microbes, plant tissues, and soils, 4) the influence of soil properties, environmental conditions and cropping on these processes and 5) the retention of airborne pollutants by plant foliage and their subsequent absorption by leaves and transport to seeds and roots.

\section{Soil-Plant-Animal Studies}

These investigations have resulted in development of a model for the environmental behavior of plutonium. The ultimate behavior of plutonium upon entrance into aerobic soils, regardless of the chemical form or oxidation state, is governed by processes which tend to result in $\mathrm{Pu}$ (IV) or Pu(III) solubilizaton (complexation) and insolubilization (hydrolysis or sorption). The major fraction of total plutonium in soil is insoluble and of low mobility (diffusion coeff $i-$ cients $<10^{-9} \mathrm{~cm}^{2} / \mathrm{sec}$ ). Of the soluble plutonium $(<2 \%)$, a major fraction $(99.9 \%)$ has a diffusion coefficient $<1 \times 10^{-6} \mathrm{~cm} 2 / \mathrm{sec}$ and appears to be present as small particulates of hydrated $\mathrm{PuO}_{2}$. The small fraction of plutonium which is available for plant uptake is complexed or in the more mobile valence states, (V) or (VI). Thermodynamic calculations indicate that the presence of $\mathrm{Pu}(\mathrm{V})$ Pu(VI) in the soil solution is theoretically possible; however, studies of the interaction of $\mathrm{Pu}(\mathrm{VI})$ with microbial metabolites indicate the likelihood of plutonium in these valences is low because of reductive reactions in soil with inorganic or organic ligands associated with the solid or aqueous phases. Furthermore, reductive processes at the plant root surface also occur. Evidence that the reduction potentials near the root membrane are sufficient to reduce $\mathrm{Pu}(\mathrm{V})-\mathrm{Pu}(\mathrm{VI})$ to $\mathrm{Pu}(\mathrm{IV})$ is evident from the established mechanisms of iron uptake. In this process, ferric iron is reduced to ferrous iron near the root and transported and reoxidized to ferric iron in the plant. Thus, the reactions of $\mathrm{Pu}$ (IV) in soil are essentially responsible for the long-term behavior of plutonium. The plutonium entering soil in a complexed form is initially soluble, but exchange reactions and degradation of the organic ligand tend to decrease its solubility over time.

The ligands most important in maintaining a soluble, plant-available level of plutonium are $\mathrm{HCO}_{3}-\mathrm{CO}_{3}$ and low molecular weight organic solubles, both of which are related to microbial metabolism during decomposition of organic materials in the soil.

The complexes of plutonium appear to be anionic and neutral, which facilitate plutonium mobility in the soil and transport to the root membrane. Although transport probably depends on the presence of the free Pu(IV) ion for some finite period of time, the potential remains for $\mathrm{Pu}$ (IV) hydrolys is to insoluble $\mathrm{Pu}(\mathrm{OH})_{m}$ at the root surface, likely explaining the residual plutonium found on root surfaces and cell walls. Evidence indicates that organoplutonium complexes serve mainly to deliver the metal to the root membrane, and the ligands are not taken up by the plant stoichiometrically with the metal. After passing the root membrane, plutonium is transported to the shoots in the xylem through formation of a number of complexes with plant ligands. Once transport is complete, plutonium is again complexed for translocation to aerial tissues.

The gut absorption of plutonium by animals also requires soluble forms of plutonium and similar chemical reactions (hydrolysis, 
complexation) govern the formation of soluble forms. The $\mathrm{pH}$ of stomach fluids $(\sim 1.5)$ is insufficient to retard hydrolysis of $\mathrm{Pu}$ (IV) to $\mathrm{Pu}(\mathrm{OH})_{m}$ but is sufficient to dissociate many weakly bound plutonium complexes.

Insoluble forms of plutonium probably hydrolyze extensively when passing to the intestine $(\mathrm{pH} \sim 7)$. When plutonium is introduced into the gut as $\mathrm{Pu}(\mathrm{V})-\mathrm{Pu}(\mathrm{VI})$ in high mass concentrations $(>1 \mathrm{~g})$ and when large excesses of a holding oxidant are present, the Pu(V)Pu(VI) remains soluble and is absorbed in significant quantities. However, the reducing potential in the gut is sufficient to reduce very low concentrations of $P u(V)$ Pu(VI) to Pu(IV) if the holding oxidant is not present. When plutonium is present in complexes in which the kinetics of dissociation are sufficiently slow, as may occur in microbial and plant systems, the plutonium remains soluble in the gut, increasing absorption. It is not known whether plutonium complexes are absorbed by the gut, but it is possible that soluble complexes may not pass gut memoranes because of steriochemical considerations.

\section{Foliar Studies}

Investigation of the foliar interception and behavior of plutonium and americium have been completed and the results submitted for publication. Biological availability of $\mathrm{Pu}$ (IV) and $\mathrm{Am}$ (III), as with essential elements, has been shown to depend on both solubility and chemical form. To evaluate the influence of solubility and chemical form, bushbean plants were contaminated with particulate aerosols containing plutonium citrate, plutonium nitrate, water-aged $\mathrm{PuO}_{2}$ and freshly prepared $\mathrm{PuO}_{2}$ and maintained for 28 days at $30 \%$ relative humidity $(\mathrm{RH})$. The relative availability of these forms of Pu(IV), as measured by the percentages of plutonium translated from foliage to seed and roots, was aged $\mathrm{PuO}_{2}>$ plutonium nitrate $>$ plutonium citrate > fresh $\mathrm{Pu}_{2}$. Relative behavior of the aged plutonium dioxide and plutonium nitrate compared with fresh $\mathrm{PuO}_{2}$ can be explained by their chemical behavior in solution. However, the comparative unavailability of the chemically stable and soluble plutonium citrate suggests that the stability of the citrate complex precludes exchange of plutonium to other ligands which may be transported under these conditions.

Moisture affects both the absorption and leaching of essential nutrients from plant foliage by influencing the wettability of hydrophobic leaf surfaces, providing a surface solution for chemical reaction, and actting as a vector for diffusion and subsequent absorption of contaminants intercepted by leaf surfaces. Studies of plants contaminated with $\mathrm{Am}_{2} \mathrm{O}_{3}$ and the four forms of plutonium show translocation to increase with both increased RH (70\%) and interinittent rainfall. The more soluble forms, plutonium nitrate and plutonium citrate, exhibited increases of approximately a hundredfold and tenfold respectively, while the oxides exhibited a two- to threefold increase. Similar studies with water-aged $\mathrm{PuO} 2$ with count modes of 0.042 to $0.104 \mathrm{um}$ show that the availability of plutonium is related to particle size distribution.

Transfer rates for plutonium and americium deposited in foliage and translocated to seeds and roots range frnm $0.043 \%$ to $0.0019 \%$. Although it is difficult to irectly compare the relative importance of the foliar versus root absorption pathway, these data demonstrate that the foliar route of entry for plutonium and americium must je considered in long-terin dose assessment and in low-level release and accident situations (Table 5.1).

Early studies were concerned with particles measuring 10 to $200 \mu \mathrm{m}$ and retention half-time of particles intercepted hy foliage was reported as approximately 14 days. Our investigations showed that particles of $<0.2 \mu \mathrm{m}$ (count mode) could not be readily removed from leaves using either wind speeds of about $24 \mathrm{~km} / \mathrm{hr}$ or hy light abrasion. Use of a simulated rainfall to evaluate retention showed that less than $3 \%$ of $\mathrm{PuO}_{2}$ and $\mathrm{AmO}_{2}$ activity intercepted by foliage could be removed by simulated rainfall conditions initiated one day following contamination. More soluble forms of plutonium, such as plutonium nitrate and plutonium citrate, were leached more readily with 14 and $50 \%$, respectively, of the surface deposits leached after one day (Figure 5.1). Leachability of all chemical forms studied decreased when time between contamination and occurrence of a simulated rainfall increased. Analyses of leachates showed that, in the case of the oxides, the majority of the activity was associated with particles. Simulated acid rainfalls ( $\mathrm{pH} 2$ ) increased the removal of plutonium oxides only slightly while markedly increasing the removal of americium oxides from foliage. Calculated retention halftimes for various chemical forms of plutonium ranged from 57 to 736 days for plutonium citrate and aged $\mathrm{PuO}_{2}$ respectively.

Detailed analyses of particle size distributions of plutonium and americium in leachates showed the majority of the insolubles to be associated with particles with mass median diameter (MMD) greater than the count mode for particles intercepted by foliage.

Retention half-times for submicron-sized particles of plutonilam and americium indicate that much of our earlier beliefs concerning the hehavior of particles on foliar surfaces are in error. Extended residence times for 
TABLE 5.1. Effect of Relative Humidity and Intermittent Rainfall on Plutonium and Americium Availability.

\begin{tabular}{|c|c|c|c|}
\hline Form & Treatment & $\begin{array}{c}\text { Transport to } \\
\text { Seed and Root, } \\
1 \% \times 10^{4}\end{array}$ & $\begin{array}{c}\text { Concentration in } \\
\text { Seed and Root. } \\
\text { dpm } / g\end{array}$ \\
\hline \multirow{3}{*}{$\begin{array}{l}\text { Plutonium Oxide } \\
\text { (fresh) }\end{array}$} & $30 \% \mathrm{RH}$ & $8.8+2.0 \quad\langle 4\rangle$ & 3.20 \\
\hline & $70 \% \mathrm{RH}$ & $11.4+0.9$ & 6.01 \\
\hline & $\begin{array}{l}70 \% \mathrm{RH} \text { and Intermittent } \\
\text { Rainfall }\end{array}$ & $26.7 \pm 2.8$ & 6.83 \\
\hline \multirow{3}{*}{$\begin{array}{l}\text { Plutonium Oxide } \\
\text { lagedj }\end{array}$} & $30 \% \mathrm{RH}$ & $45.8+8.5$ & 16.4 \\
\hline & $70 \% \mathrm{RH}$ & $97.0 \pm 21.0 \quad(4)$ & 41.0 \\
\hline & $\begin{array}{l}70 \% \mathrm{RH} \text { and Intermittent } \\
\text { Rainfall }\end{array}$ & $53.9+9.2(12)$ & 22.2 \\
\hline \multirow[t]{2}{*}{ Plutonium Citrate } & $30 \% \mathrm{RH}$ & $11.0 \pm 1.3$ & 20.4 \\
\hline & $30 \%+$ Intermittent Rainfalt & $116 \pm 15$ & 139.9 \\
\hline \multirow[t]{2}{*}{ Plutonium Nitrate } & $30 \% \mathrm{RH}$ & $35.1 \pm 0.9$ & 124.4 \\
\hline & $\begin{array}{l}30 \%, \mathrm{RH} \text { and intermittent } \\
\text { Rainfall }\end{array}$ & $427+80$ & 1088 \\
\hline \multirow[t]{3}{*}{ Americium Oxide } & $30 \% \mathrm{RH}$ & $16.1+1.9$ & 4.97 \\
\hline & $\begin{array}{l}30 \% \mathrm{RH}+\text { intermittent Rain- } \\
\text { fali }\end{array}$ & $20.3+2.7$ & 4.62 \\
\hline & $30 \%$ RH + Misting & $31.7+5.2$ & 7.12 \\
\hline
\end{tabular}

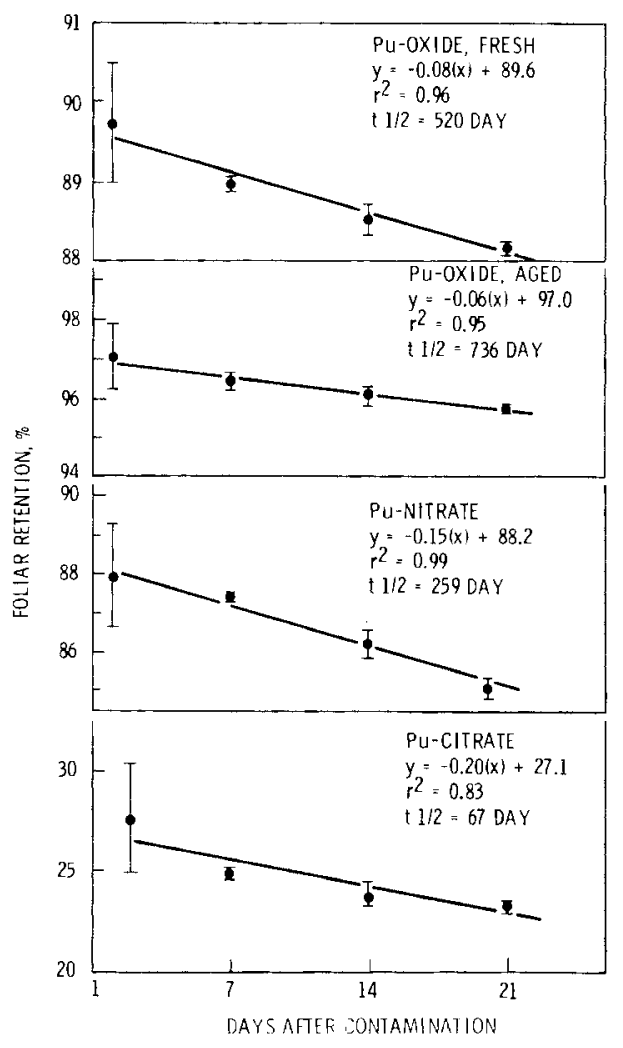

particles intercepted by plant canopies pro$v i d e$ the time for chemical modification of surface contaminants and for absorption and translocation to edible plant tissues in the case of many agronomic crops. Extended retention hali-times and the relative bioavailability of transuranic elements deposited on foliar surfaces requires an evaluation of these parameters in dose assessment models.

FICURE 5.1. Foliar Retention of Plutonium Forms. 



\title{
- Quantitative Aspects of Plutonium Field Studies
}

\author{
Principal Investigators: R. O. Gilbert, \\ P. G. Doctor and L. L. Eberhardt \\ Consultant: P. Delfiner
}

This project is directed toward the development and use of appropriate statistical design and analysis procedures in field studies of environmental plutonium and other transuranics and radionuclides. This effort is motivated by the large variability and skewed frequency distributions usually observed in environmental transuranic data. During the past year we have made major efforts in two areas: 1) the publication and distribution of five issues of TRAN-STAT, a periodical that discusses statistical aspects of environmental transuranic studies and 2) research into appropriate statistical methods for estimating and analyzing ratio data such as concentration and inventory ratios. Progress was also made in the development of $\mathrm{kriging}$ techniques for estimating spatial pattern of transuranics. Additional activities include involvement in the North Marshall Islands Advisory Group and in the Nevada Applied Ecology Group (NAEG) environmental transuranic studies (under separate funding) on the Nevada Test Site.

TRAN-STAT: Statistics for Environmental Transuranic Studies

TRAN-STAT is a publication we periodically distribute to those engaged in environmental transuranic studies for DOE. Publication began in September 1977 and five issues have been distributed so far. Some topics discussed in these issues are the role of the statistician in environmental transuranic studies, effective data summaries and displays, statistical aspects of environmental cleanup studies, statistical problems associated with compositing samples, and the use of nonparametric procedures in environmental studies. Topics to be discussed in future issues are expected to include statistical aspects of estimating transfer coefficients in process models, the use of data transformation, design aspects of field studies, regression analyses, and statistical analyses appropriate for handiing "not-detected" or "less-than" concentrations. The overall goal of TRAN-STAT is to increase awareness of appropriate statistical methods for transuranic research. However, its publication has also been a strong motivation for reviewing the statistical literature and hence being prepared to make progress in the development of new statistical methods for transuranic studies.

\section{Statistical Analysis of Ratio Data}

The goals of DOE's Transuranic Environmental Program include determining the rate at which transuranium elements move from one ecosystem component to another, up to and including man. In practice, these transfer rates are usually estimated by computing the ratio of the amount of transuranic in one ecosystem compartment to that of the donor compartment. During the past year we have continued to explore the statistical problems of ratio data.

A basic assumption underlying the use of a ratio is that the numerator and denominator have a multiplicative relationship. In practice this assumption may not be realistic. We are investigating the feasibility of using multivariate and other statistical techniques when this multiplicative relationship is not valid. We are also attempting to understand problems in ratio estimation that can arise when aliquot sizes are so small that resulting concentrations are unreliable. We feel it is important that researchers understand and appreciate the difficulties involved in making inferences on the basis of ratio data. 
North Marshall Is lands Advisory Group on Cleanup of Enewetak Atoll

In March 1973 Dr. Gilbert became a member of the North Marsinall Islands Group (W. J. Bair, PNL, chairman). This group was formed to evaluate and advise DOE's radiological support of the current cleanup and rehabilitation of the Enewetak Atol1. The Advisory Group reports to the Director of Operational and Environmental Safety. It met on several occasions during 1979 and visited Enewetak to observe the current cleanup operation and to meet with DOE scientists providing technical support.

Dr. Gilbert's involvement in these activities has proved beneficial to this quantitative aspects program in a number of respects. close interaction with statisticians responsible for characterizing the transuranic contaminations on the islands of the atoll have contributed to our understanding of statistical approaches useful for making cleanup decisions. Other benefits accrue from keeping abreast of the experiment studies on plant uptake, modeling and plowing being conducted on the atoll. The present Enewetak cleanup effort will provide valuable opportunities to apply statistical techniques and criteria to transuranic cleanup situations.

Nevada Test Site (NTS) Environmental Transuranic Studies

The objectives of this program, funded by the Nevada Applied Ecology Group (NAEG), are similar to those of the transuranic program of the Office of Health and Environmental Research (OHER). We have participated in NAEG statistical design and analysis programs since 1971. Our experience there indirectly contributes to this quantitative aspects program and hence is briefly described here.

Because the overall NAEG program was reduced during the past year, statistical design and analvsis was reduced correspondingly. Hence, our NAEG activities mainly consisted nf writing several reports for publication in the proceedings of the NAEG Plutonium Information Conference held in San Diego in February 1973 (NV0-192). These reports cover statistical topics of interest to both NAEG and OHER.

One of the topics discussed in our reports is the analysis of data for studying the relationsilip between 241 Am concentrations in soil and size of aliquot. These data indicate an increased variability and skewness of aliquot data as al iquot sizes decrease from 100 to 19 . Our studies show geometric means and medians to be a function of aliquot size, but arithmetic means do not show this tendency. The optimum allocation of sampling effort between field samples and aliquots per field sample is another topic discussed with aliquot tata analysis. Results of these studies should be relevant wherever transuranics occur as particles and at low concentrations. We have used these al iquot data in our evaluation of appropriate statistical methods for ratios as discussed above.

A paper lias been prepared (partly funded under this quantitative aspects program) that. deals with estimating the spatial distribution of plutonium using kriging techniques. An expert on kriging from the Centre de Geostatistique, Fontainebleau, France, works as a consultant to PNL on the applicability of kriging to transuranic contamination and is concerned with estimating the spatial distribution of plutonium at a safety shot site on ivT. However, the statistical techniques employed may have significance to OHER studies, since a characterization of spatial pattern usually is included or precedes field studies for quantifying rates of movement among ecosystem components or evaluating radiological hazards to man, two goals of the DOE environinental research program on iransuranics. 


\title{
- Analog Elements for Transuranic Chemistry
}

\author{
Principal Investigators: W. C. Weimer, J. C. Laul and J. C. Kutt
}

Naturally occurring elements which serve as analogs for some of the transuranic elements have been demonstrated to be taken up by plants as a smooth function of elemental ionic radius. They remain unfractionated over geologic time periods. Pools of potentially available rare earth elements have been defined by chemical extraction methods and have been related to the pool of fallout transuranic elements in soils.

Patterns of Rare Earth Analog Elements in Biological Materials

The rare earth element concentrations and chondrite-normalized concentration patterns for a number of biological materials and biologically derived samples have been determined and compared to the concentrations and concentration patterns in terrestrial soils. In all cases, the concentration patterns of the rare earth elements in the biological materials show no elemental fractionation or selective uptake as a function of ionic radius and are identical to the patterns determined for all soils thus far examined. These data indicate that, throughout geologic time, elements of similar ionic radi $i$ and chemical properties are not fractionated, but behave as though they were one.

Some of the rare earth elements have been chosen for use as geochemical and biochemical analogs for a few of the transuranics. These are principally neodymium for americium and curium. This selection was based primarily upon the elements' nearly identical ionic radi $i$ and very similar chemical properties. The biogeochemical behavior of the naturallyoccurring analog element is intended to represent the long-term behavior of its corresponding transuranic element. One approach to determining whether elements with similar ionic radii and similar chemistries do behave identically over geologic time is to examine the Dehavior of the entire series of the rare earth elements. The concentrations of the rare earth elements (normalized to the rare earth concentrations in chondrites to facilitate interpretation) in several biological samples and hiologically derived materials are given in Figure 5.?. These data are for snap beans, four recently harvested grains, and two biologically derived materials--raw coal, and raw oil shale.

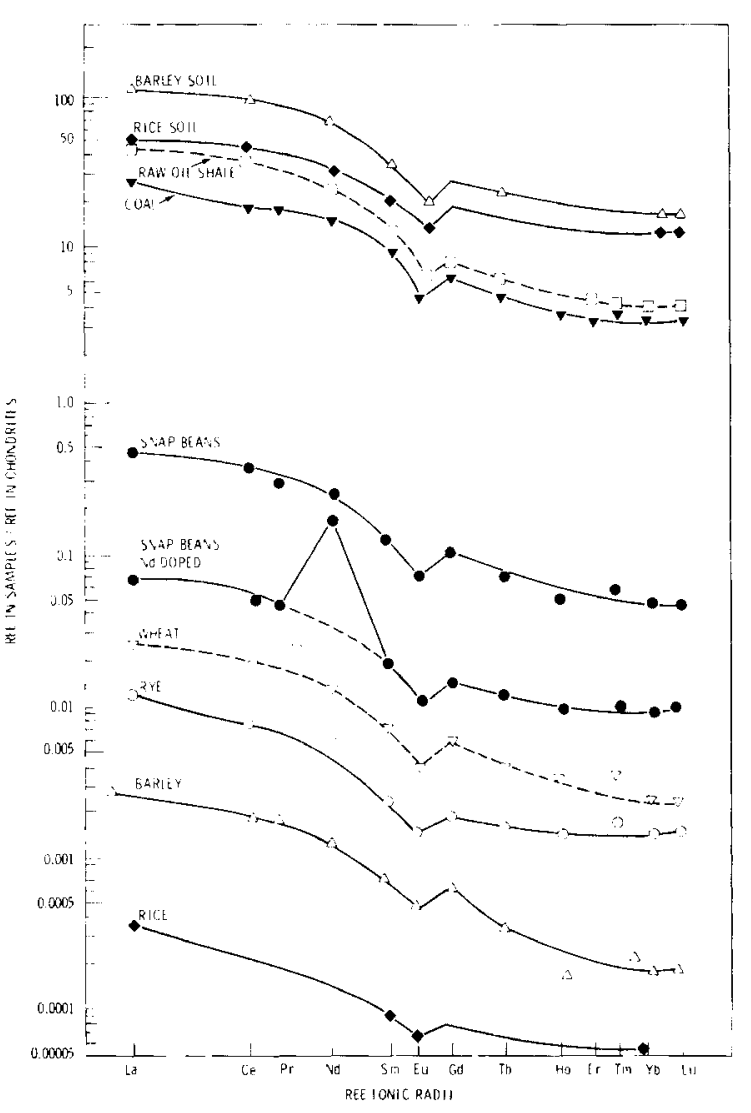

FIGURE 5.2. Patterns of Rare Earth Analog Elements in Biological Materials.

(For comparative purposes, the data for two soils are also included.) Two aspects of these data are remarkable. The first is that these data represent a concentration range of approximately $10^{6}$ times. Throughout this 
entire concentration range, there is no evidence of any elemental fractionation. The pattern of the rare earth elements is remarkably consistent. Second, these data represent a geologic time scale going from the very recent uptake of the rare earth elements by the grains and snap beans, to the rare earth content of the soils derived from the weathering of primary minerals, to millions of years ago when the rare earth elements in the coal and oil shale were incorporated by living plant species. These data offer conclusive evidence that no selective uptake or differentiation of elements of these ionic radii occur over geologic time periods. Therefore, the behavior of americium and curium, the transuranic analogs to neodymium, should be biochemically and geochemically identical to neodymium throughout very long periods of time, just as its neighboring rare earth elements have behaved identically over millions of years.

Availability of Native Rare Earth Elements and Fallout Transuranic Elements from SoiTs to Plants

The purposes of this investigation are 1) to determine the concentration ratios for the plant incorporation of the entire series of rare earth elements from bulk soils and from several soil pools defined by chemical extraction techniques, and 2) to compare these concentration ratios with those measured for the uptake of fallout transuranic elements plutonium and americium. The initial results of these studies indicate that concentration ratios for the fallout transuranics are most closely matched by concentration ratios for the rare earth elements which are calculated from an available pool defined by a $1 \mathrm{~N} \mathrm{HNO}_{3}-9 \% \mathrm{H}_{2} \mathrm{O}_{2}$ extraction of the soil.

The biological incorporation of certain native rare earth elements from soils may serve as the natural analogs for the incorporation of the transuranic elements which have reached a weathered, steady-state equilibrium in the environment. Naturally occurring rare earth elements in soils are divided into two pools. One of these pools contains the rare earth elements which are bound within primary and secondary minerals and are not biologically available. The other includes rare earth elements which have been released into the soil by the biogeochemical weathering of these minerals and which are potentialiy biologically available. Several different chemical extraction techniques have been employed to determine the magnitude of the available pool of the entire series of rare earth elements in soils and to relate the rare earth extractants to the total soil rare earth content. The specific extractants we have chosen represent both a broad range of equilibrium $\mathrm{pH}$ values and the effect of the destruction of the soil organic matter. The chemical strength of extractants ranged from quartz distilled water to I $\mathrm{N} \mathrm{HNO}_{3}-9 \% \mathrm{H}_{2} \mathrm{O}_{2}$. Table 5.2 is a listing of the chemical treatment employed and the fraction of the total soi] rare earth content extracted from each of two soils which have been examined in detail. (These data are expressed as the averages for the entire series of rare earth elements since the proportions extracted have been shown to be independent of the specific element.)

The rare earth element concentration ratios from each of these chemically defined pools have been determined for several plants. These data are presented in Table 5.3, together with the corresponding fallout transuranic element concentration ratios for comparison. The data demonstrate two significant points. First, although the proportion of the rare earth elements removed by chemical treatment is quite different for the two soils (Table 5.2), the rare earth element concentration ratios calculated from each of these pools are very similar. This finding suggests that the chemical treatments are removing materials which are potentially biologically available.

TABLE 5.2. Chemical Extractability of Rare Earth Elements from Soil.

\begin{tabular}{|c|c|c|c|c|}
\hline \multirow[b]{2}{*}{ Soil } & \multicolumn{4}{|c|}{ Fraction of Total Rare Earth Element Content in Soil Extracted by } \\
\hline & $1 \underline{\mathrm{N}} \mathrm{HNO}_{3}-9 \% \mathrm{H}_{2} \mathrm{O}_{2}$ & $\mathrm{pH} 2-9 \% \mathrm{H}_{2} \mathrm{O}_{2}$ & $\mathrm{pH} 2$ & $\mathrm{H}_{2} \mathrm{O}$ \\
\hline $\begin{array}{l}\text { Cape Cod } \\
\text { (EML Garden Plot) }\end{array}$ & $3.4 \times 10^{-2}$ & $8.6 \times 10^{-3}$ & $2.2 \times 10^{-3}$ & $3.7 \times 10^{-4}$ \\
\hline $\begin{array}{l}\text { Ritzville } \\
\text { (ALE Lysimeter Field) }\end{array}$ & $2.5 \times 10^{-1}$ & $1.5 \times 10^{-2}$ & $1.0 \times 10^{-2}$ & $5.2 \times 10^{-4}$ \\
\hline
\end{tabular}

(a) Data are average extractions for the entire series of rare earth elements. 
TABLE 5.3. Concentration Ratios for Plant Uptake of Rare Earth and Transuranic Elements.

\begin{tabular}{|c|c|c|c|c|c|c|c|}
\hline \multirow[b]{2}{*}{ Plant } & \multicolumn{5}{|c|}{ Rare Earth Element Concentration Ratios (a) from } & \multicolumn{2}{|c|}{$\begin{array}{l}\text { Transuranic Element } \\
\text { Ratios from Bulk Soil (b) }\end{array}$} \\
\hline & Bulk Soil & $1 \underline{\mathrm{N}} \mathrm{HNO}_{3}-9 \% \mathrm{H}_{2} \mathrm{O}_{2}$ & $\mathrm{pH} 2-9 \% \mathrm{H}_{2} \mathrm{O}_{2}$ & $\mathrm{pH} 2$ & $\mathrm{H}_{2} \mathrm{O}$ & 239-240Pu & ${ }^{241} \mathrm{Am}$ \\
\hline \multicolumn{8}{|l|}{ EML Soil } \\
\hline Peas & $1.1 \times 10^{-4}$ & $4.3 \times 10^{-3}$ & $1.8 \times 10^{-2}$ & $4.8 \times 10^{-2}$ & 1.4 & $1.4 \times 10^{-3}$ & $6.0 \times 10^{-3}$ \\
\hline Potatoes & $5.3 \times 10^{-5}$ & $1.6 \times 10^{-3}$ & $1.0 \times 10^{-2}$ & $2.1 \times 10^{-2}$ & 2.2 & $7.1 \times 10^{-4}$ & $6.0 \times 10^{-3}$ \\
\hline Corn & $8.1 \times 10^{-5}$ & $2.7 \times 10^{-3}$ & $2.1 \times 10^{-2}$ & $4.0 \times 10^{-2}$ & 4.6 & $1.4 \times 10^{-2}$ & $6.1 \times 10^{-3}$ \\
\hline Squash & $4.5 \times 10^{-4}$ & $1.8 \times 10^{-2}$ & $9.7 \times 10^{-2}$ & $2.6 \times 10^{-1}$ & 10.4 & $6.4 \times 10^{-3}$ & $9.9 \times 10^{-3}$ \\
\hline \multicolumn{8}{|l|}{ ALE Soil } \\
\hline $\begin{array}{l}\text { Cheatgrass } \\
\text { (whole plants) }\end{array}$ & $3.6 \times 10^{-4}$ & $1.5 \times 10^{-3}$ & $8.4 \times 10^{-2}$ & $3.9 \times 10^{-2}$ & 12.9 & - & - \\
\hline
\end{tabular}

(a) Data are average concentration ratios for the entire series of rare earth elements.

(b) Data provided by E. P. Hardy of the DOE Environmental Measurement Laboratory.

In addition, the fallout transuranic element concentration ratios (determined by the Environmental Measurement Laboratory) are of the same order of magnitude but about twofold lower than those calculated for natural rare earth incorporation from an elemental pool defined by the $1 \mathrm{~N} \mathrm{HNO} 3-9 \% \mathrm{H}_{2} \mathrm{O}_{2}$ extract. Since this extraction is rather harsh and may represent an upper limit to the biologically available pool, it appears that the rare earths may represent a more completely equilibrated and aged pool for plant uptake than the $241 \mathrm{Am}$. Thus, one may conclude that the 247 Am may become more available for plant uptake, perhaps by a factor of 2 or more, with aging time in the soil. These data do, however, suggest that this extraction removes many rare earth chemical forms which may be similar to or bound in the soils by similar mechanisms to the fallout transuranic elements.

Continuing work is necessary on the extractability of both native rare earth elements and fallout transuranics from a variety of soils. However, results thus far indicate that it will be possible to relate the uptake of the rare earth elements from the weathered pool of available elements to the uptake of transuranic elements, and to use this relationship to estimate the ultimate availability of transuranics in the environment. 



\title{
- Transuranic Weathering in Plants
}

\author{
Principal Investigators: R. G. Schreckhise, ]. F. Cline \\ and L. L. Cadwell \\ Technical Assistants: W. J. Christian, M. A. Combs, \\ M. J. Harris, 1.. F. Nelson and H. A. Siveany \\ Norcus Appointee: D. T. Farrar
}

Releases of long-lived transuranium elements to ecological systems pose questions for which data are very limited. Quantitative information is needed on the potential pathways through food chains to assess the potential hazards to man. Of special interest is the offect of time (weathering, aging, and associated biological processes in soil) on the change in availability of transuranium elements to be takan up by plants from soil. This study provides valuable information on the effects of weathering and aging on the uptake of transuranics from soil by range and crop plants grown under realistic field conditions.

Comparative Uptake and Distribution of Transuranics in Range and Crop P lants

In this study, a comparison was made of the uptake of the nitrate forms of $238 \mathrm{pu}$, $239 \mathrm{Pu}, 24 \mathrm{I}_{\mathrm{Am}}, 244 \mathrm{Cm}$ and $237 \mathrm{~Np}$ from soil into selected parts of four plant species grown under field conditions. Alfalfa, barley, peas and cheatgrass were grown outdoors in small weighing lysimeters filled with soil that contained a single nitrate form at one of two treatment levels. The plants were harvested at maturity, divided into selected components and radiochemically analyzed by alpha-energy andysis. Soil concentration did not appear to affect the plant uptake of $238 \mathrm{pu}, 239 \mathrm{Pu}, 241_{\mathrm{Am}}$ or $244 \mathrm{Cm}$ for the two levels utilized. The relative uptakes of $238 \mathrm{pu}$ and $239 \mathrm{Pu}$ were not significantly different. The relative 241 Am uptake values were not statistically different from the $244 \mathrm{Cm}$ values. The relative plant uptake of the four transuranium elements (Figure 5.3) was $\mathrm{Np}>\mathrm{Cm} \simeq \mathrm{Am}>\mathrm{Pu}$. Relative uptake values of neptunium into various plant parts ranged from ?,200 to 45,000 times as great as for plutonium, while americium and curium values were 10 to 20 times greater.

If the concentration ratio (CR) of plutonium is approximately 0.0001 and $237 \mathrm{~Np}$ was taken up into the entire plant some 3900 times more readily than plutonium, one can infer that the $C R$ value for neptunium would be about 0.4. That is, under usual agronomic conditions, the concentration of vegetation growing on soil contaminated with 237Np in the upper 15 to $20 \mathrm{~cm}$ would be equal to approximately one-half of the soil concentration on a dry weight basis. Likewise, the $C R$ values for $241 \mathrm{Am}$ and $244 \mathrm{Cm}$ would be expected to be about 0.00 ? since the relative uptake of these two transuranics was approximately 15 times as great as plutonium. Significance of these CR values can be related to transuranics associated with plutonium breeder reactor fuels. The relative abundance of a number of long-lived transuranics relative to $239 \mathrm{Pu}$ was calculated in spent Liquid Metal Fast Breeder Reactor (LMFBR) fuels. As shown in Table 5.4, the estimated concentration of $241 \mathrm{Am}, 242 \mathrm{Cm}, 237 \mathrm{~Np}$ and $239 \mathrm{~Np}$ in vegetation is higher than $239 \mathrm{Pu}$ for various time periods following environmental releases of spent LMFBR fuels.

Another interesting finding was the low concentration of transuranics in pea and barley seeds when compared with the entire plant. This is important because, in many dose assessment models, the CR values utilized are often calculated using the entire aboveground $\mathrm{plant}$. As shown in this study, the levels of plutonium, americium, and curium in barley seeds were 30 to 50 times lower than the entire plant and five times lower for neptunium. Pea seeds were some 70 to 230 times lower for plutonium, americium, 


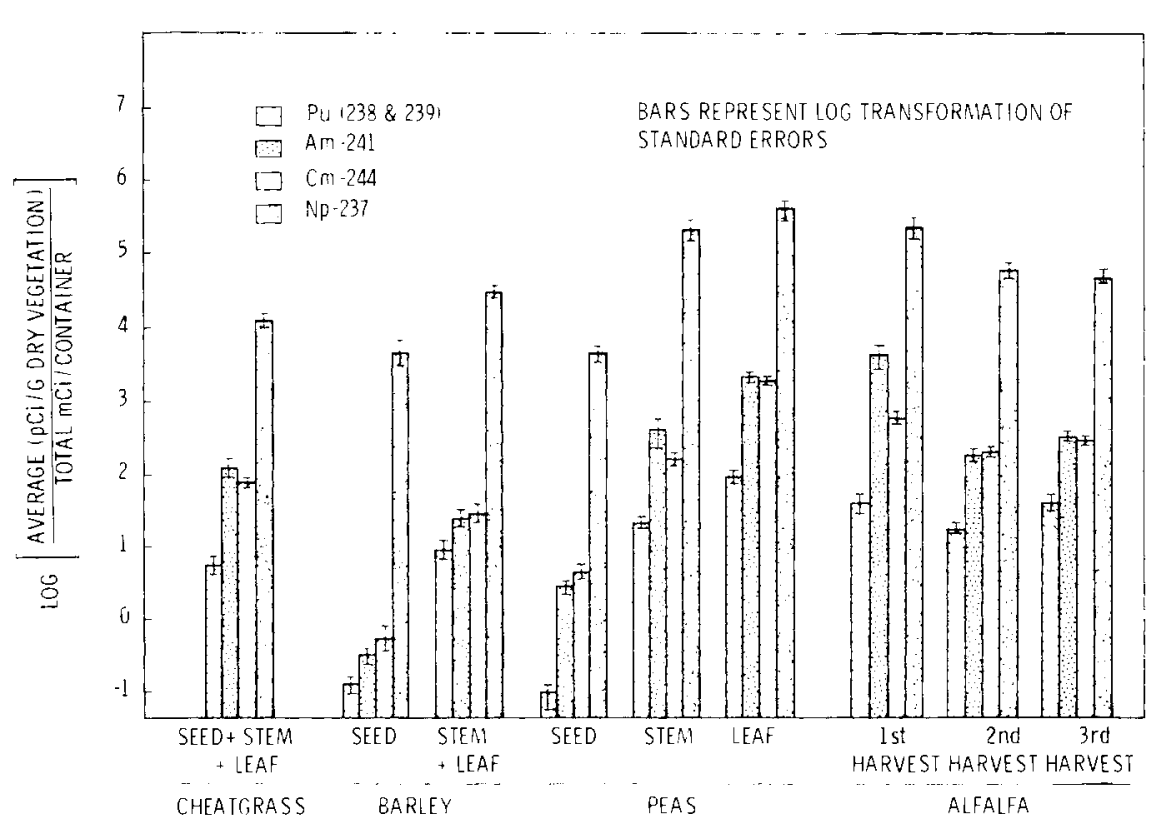

FIGURE 5.3. Relative Uptake of Transuranics into Various Plant Parts.

TABLE 5.4. Comparison of the Relative Importance of Americium, Curium and Neptunium to ${ }^{239 P u}$ for Relating Plant Uptake of Spent LMFBR Fuels Following Irradiation.

\begin{tabular}{|c|c|c|c|c|c|c|c|c|}
\hline \multirow[b]{3}{*}{ Nuclide } & \multicolumn{5}{|c|}{ Data Summarized by Thomas and Healy (a) } & \multicolumn{3}{|c|}{ Results from this Study } \\
\hline & \multicolumn{2}{|c|}{$\begin{array}{c}\text { Abundance in } \\
\text { Spent LMFBR Fuels } \\
\text { Relative to }{ }^{239} \mathrm{Pu} \\
\end{array}$} & \multirow[b]{2}{*}{$\begin{array}{l}\text { Plant Uptake } \\
\text { Relative to }{ }^{239} \mathrm{Pu}\end{array}$} & \multicolumn{2}{|c|}{$\begin{array}{c}\text { Importance } \\
\text { Relative to }{ }^{239} \mathrm{Pu} \\
\end{array}$} & \multirow[b]{2}{*}{$\begin{array}{l}\text { Plant Uptake } \\
\text { Relative to }{ }^{239} \mathrm{Pu}\end{array}$} & \multicolumn{2}{|c|}{$\begin{array}{c}\text { Importance } \\
\text { Relative to }{ }^{239} \mathrm{Pu}\end{array}$} \\
\hline & $3 y$ & $1000 y$ & & $3 y$ & $1000 y$ & & $3 y$ & $1000 y$ \\
\hline${ }^{241} \mathrm{Am}$ & 1.5 & 1.6 & 800 & 1200. & 1300. & 20 & 30. & 33 \\
\hline${ }^{242} \mathrm{Cm}$ & 0.28 & 0.00034 & 15 & 4.2 & 0.0051 & 20 & 5.6 & 0.0068 \\
\hline${ }^{244} \mathrm{Cm}$ & 0.40 & 0 & 15 & 6.1 & 0 & 20 & 8.1 & 0 \\
\hline${ }^{237} \mathrm{~Np}$ & $1.9 \times 10^{-5}$ & $1.2 \times 10^{-3}$ & 730 & 0.014 & 0.89 & 4,000 & 0.08 & 4.8 \\
\hline${ }^{239} \mathrm{~Np}$ & $1.8 \times 10^{-2}$ & $1.7 \times 10^{-2}$ & 730 & 13. & 12. & 4,000 & 72. & 68. \\
\hline
\end{tabular}

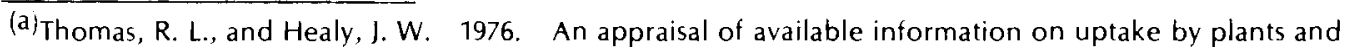
transplutonium elements and neptunium. ERDA Report LA-6460-MS, Los Alamos Scientific Laboratory. Springfield, VA: NTIS.

Data used in the above report was taken from the following sources:

Bell, M. J. 1970. Heavy element composition of spent power reactor fuels. USAEC Report ORNL-TM-2897, Oak Ridge National Laboratory. Springfield, VA: NTIS.

Price, K. R. 1972. Uptake of ${ }^{237} \mathrm{~Np},{ }^{239} \mathrm{Pu},{ }^{241} \mathrm{Am}$ and ${ }^{244} \mathrm{Cm}$ from soil by tumbleweed and cheatgrass. USAEC Report BNWL-1688, Battelle, Pacific Northwest Laboratories. Springfield, VA: NTIS. 
and curium, and 30 times lower for neptunium. Differences in plant part concentrations must be considered when utilizing $C R$ values in dose assessment models, and can also be used to describe some of the discrepancy in CR values reported in the literature.

\section{Plutonium Movement Within a So il Column}

Samples of soil from three lysimeters were used to document the vertical movement of plutonium after four growing seasons. The lysimeters were originally spiked in 1974 with a thin layer of 238pu approximately 10 to $10.6 \mathrm{~cm}$ below the surface. The lysimeters were maintained in an outdoor enclosure and planted continuously with peas, barley or cheatgrass. After the 1977 harvest season, the lysimeters were brought into the laboratory for soil sampling. Horizontal cores were obtained at depths ranging from 5 to $50 \mathrm{~cm}$. Analyses for $238 \mathrm{Pu}$ concentration in the soil were performed by LFE Environmental

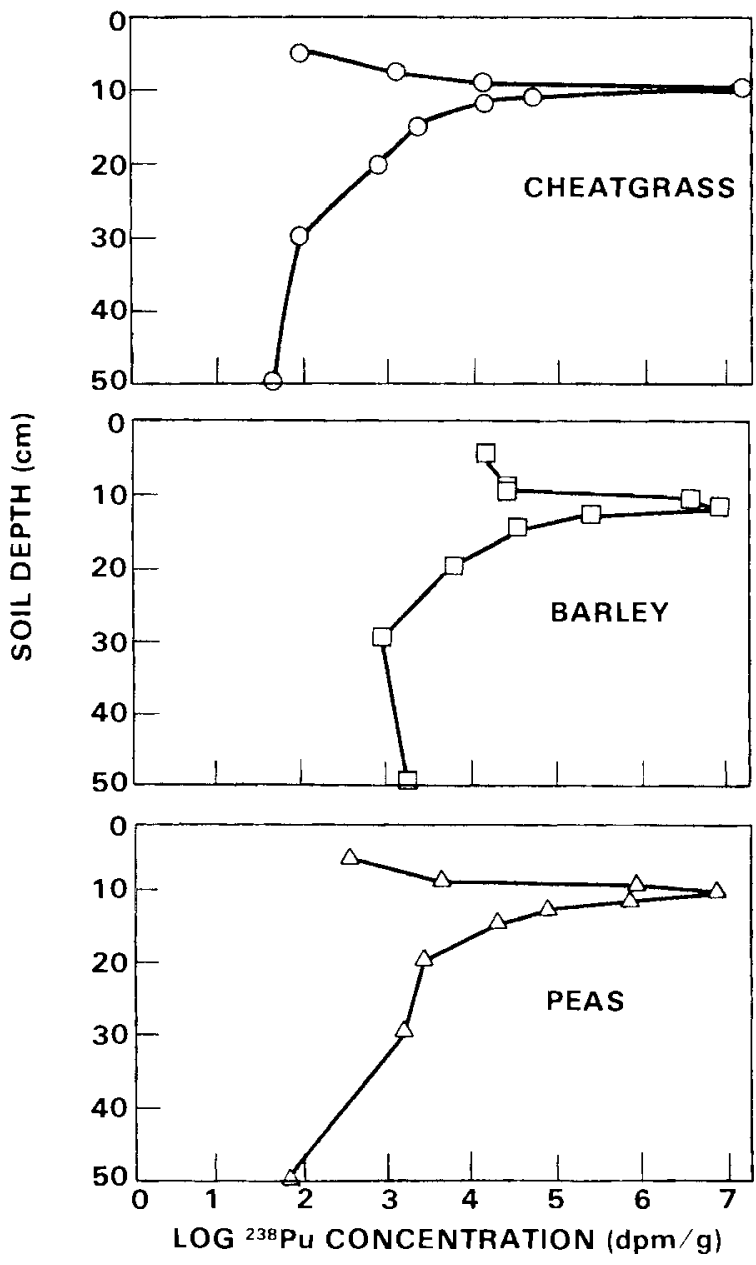

FIGURE 5.4. Concentration of ${ }^{238} \mathrm{Pu}$ in Field Lysimeters at Various Depths Below Soil Surface Following Four Harvest Seasons.
Analysis Laboratory in Richmond, California. Figure 5.4 shows the distribution of $238 \mathrm{Pu}$ within the soil column after four harvest seasons. The apparent downward and upward movement of plutonium in the lysimeters indicate that mechanisms other than just chemical processes may be involved.

\section{Placement of ${ }^{239} \mathrm{Pu}-0 \times$ ide Into Field \\ Lysimeters}

Sixty-nine mg of $239 \mathrm{pu}$ oxide were placed in each of 20 field lysimeters. The spiking solution was prepared by grinding 239pu-oxide in a standard ceramic mortar, suspending it in triple distilled water and adding a surfactant, lignin sulfonate, to the solution. The suspension was treated intermittently in a ultrasonic cleaner for a total of about $50 \mathrm{hr}$. The ultrasonic treatment and addition of the lignin sulfonate appeared to reduce the amount of particle aggregates which settled out during the procedure. While the suspension was being stirred continuousiy by a magnetic stirrer, aliquots were pipetted and transferred to vials. The vials were then gamma-counted. Contents from three of the vials were analyzed for total 239Pu content by normal alpha-energy analys is techniques. These data were used to crosscalibrate the gamma-counting system to estimate the amount of $239 \mathrm{pu}$ in each of the remaining vials. The maximum gamma-count deviation of any sample from the average was less than $2 \%$.

Following calibration, the solution in each vial was stirred and then pipetted directly to prepared lysimeters containing $14.5 \mathrm{~kg}$ oven-dried soil. The empty vials were gamma-counted to determine the total amount of $239 \mathrm{Pu}-0 x i d e$ transferred to each lysimeter. After the 239pu-oxide suspensions were pipetted, an additional $7.7 \mathrm{~kg}$ of $50 i 1$ was added to each lysimeter. Ten additional Tysimeters containing the nitrate form of the $239 \mathrm{Pu}$ were also prepared for comparison purposes. Half of the lysimeters were planted with peas and half with barley. The plants were harvested at maturity and prepared for radiochemical analysis.

Three of the original vials were utilized to determine the particle size distribution of the 239pu-oxide solution using sedimentation and filtration techniques. These measurements showed that $93.9 \%$ of the activity was associated with particles with an activity median Stokes diameter (AMSO) equal to $6.1 \mu \mathrm{m}$ with a geometric standard deviation (GSD) of $1.3 \mu \mathrm{m}, 6 \%$ associated with particle with an AMSD $=1.63 \mu \mathrm{m}($ GSD $=2.7 \mathrm{~m})$ and $0.1 \%$ of the activity passed through a $0.1 \mu \mathrm{m}$ filter. 



\title{
- Radioecology of Nuclear Fuel Cycles
}

\author{
Principal Investigators: R. G. Schreckhise, R. M. Emery, L. E. Rogers, \\ L. L. Cadwell, J. F. Cline, R. E. Fitzner, K. A. Gano, T. M. Poston and \\ W. H. Rickard \\ Technical Assistance: W. J. Christian, M. A. Combs, M. J. Harris, \\ D. C. Klopfer, M. G. LaRiviere, L. F. Nelson, H. A. Sweany and J. L.. Warren \\ Norcus Appointee: D. T. Farrar \\ Consultant: J. H. Larsen
}

Radioecology of nuclear wastes was pioneered in the western United States on the Hanford Site during the early 1940's when the Columbia River provided coolant water for production reactors. Ecological studies centered upon fish and waterfowl as vectors transporting radionuclides to people. After the shutdown of production reactors, the radionuclide content of Columbia River water declined. Attention was then directed towards radionuclides released into the environment as a result of chenical processing of irradiated fuel and storage radioactive wastes. Sites where radioactive wastes are found are solid waste burial ground, soils below liquid storage areas, surface ditches and ponds, and the terrestrial environment around chemical processing facilities that discharge airborne radioactive debris from stacks. This study provides information to help assess the environmental impacts and certain potential.human hazards associated with nuclear fuel cycles. A data base is being developed to define and quantify biological transport routes which will permit credible predictions and assessment of routine and potential large-scale releases of radionuclides and other toxic materials. These data, used in assessment models, will increase the accuracy of estimating radiation doses to man and other biota. Information obtained from existing storage and disposal sites will provide a meaningful radioecological perspective with which to improve the effectiveness of waste management practices. Results will provide information to determine if waste management procedures on the Hanford Site have caused ecological perturbations and if so, determine the source, nature and magnitude of such disturbances.

Important companion studies also are under way. They are funded through local intercontractor support agreements rather than through the Office of Health and Environmental Research. These studies involve short-term assistance to Hanford $\mathrm{plant}$ personnel concerned with characterization of particular landscape subunits impacted by operation of nuclear facilities. See Section 10.0 for intercontractor studies. 
Aquatic Radioecology of Waste Management Areas

This study characterized the linnological and radiological conditions of aquatic environments on the Hanford Site and attempted to determine if nuclear waste discharges can be related to ecological variation among these systems. The aquatic systems that were studied are Gable Mountain Pond, West Pond, the B-Pond system, including B-3 and A-29 ditches, the U-Pond system including $\mathrm{Z}-19$ ditch, and the 100-N trench (Figure 5.5). All study sites received wastes directly from nuclear facilities except West Pond, which is included in this investigation because of its natural accumulation of radioactivity and its interesting limnology.

Each system has been historically described and assessed for its physical, chemical, and biological limnology and for its general radioactive character, expressed as doses from the sediments and concentrations of alpha-, beta- and gamma-emitting radionuclides in the water. Maximum dose rates and radionuclide concentrations were used to group these systems into three categories differentiated by relative content of nuclear wastes. The B-Pond system and West Pond fell into the lowest category of nuclear waste content, while 100-N trench alone represented the

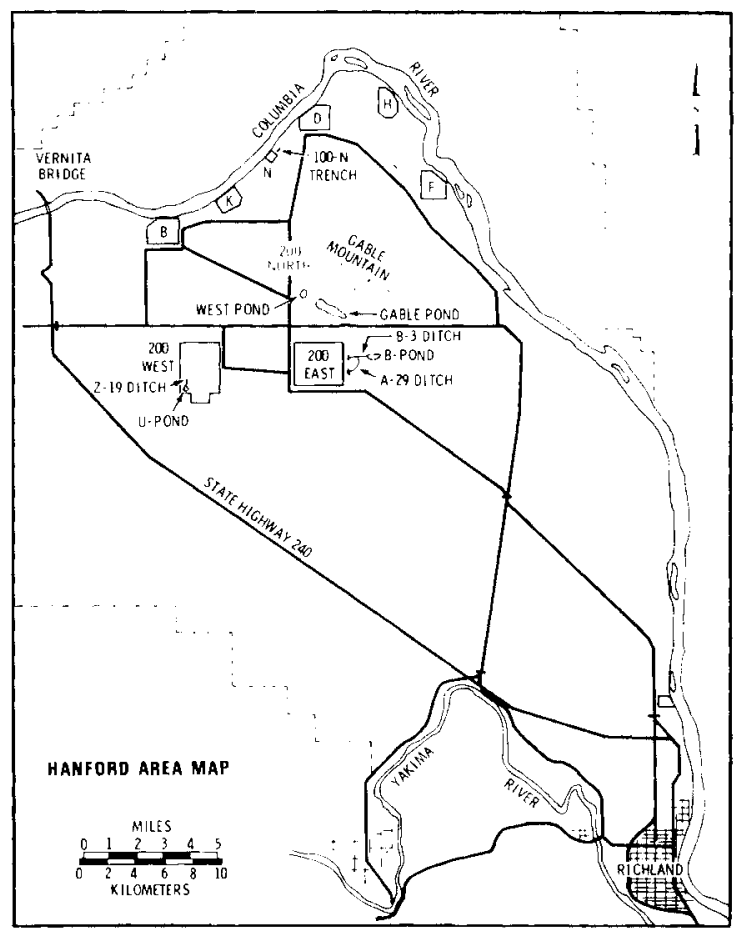

FIGURE 5.5. The Aquatic Systems on the Hanford Site. Reactor sites are located along the Columbia River and are designated by letter. Only the N-reactor is currently in operation. highest category. A mid-range grouping was suggested by Gable Mountain Pond and the U-Pond system, although the maximum water activity of these systems showed considerable overlap with those in the other groups.

Literature resources (Polikarpov 1966 , Eisenbad 1973, Whicker and Fraley 1974, Blumer, Fix and Speer 1976, IAEA 1973) are used to identify minimum levels of radiation harmful to some aquatic organisms and terrestrial communities. The range of radiation dose observed to be marginally damaging to these biological systems was compared to the measured levels of radiation in the Hanford ponds and streams to determine if radiation from nuclear wastes in these systems is sufficient to affect the aquatic communities that colonize them (Figure 5.6).

A11 systems supported populations of common algae, macrophytes, invertebrates, and in some cases, fish. Although the variety in algal populations was reduced in $100-\mathrm{N}$ trench and Z-19 ditch, variety in other types of biota was not. Community structures in these systems appear to be as diverse as those in the Columbia River but occasionally less diverse than in some streams mentioned in offsite references. The productivity of plant life, invertebrates and fish in these systems did not appear to depend on the relative amounts of nuclear waste contamination. Furthermore, their rates of productivity resembled those measured in aquatic environments not associated with nuclear activities. In the parameters studied, we found no conclusive evidence that the nuclear wastes discharged into Hanford ponds and streams have
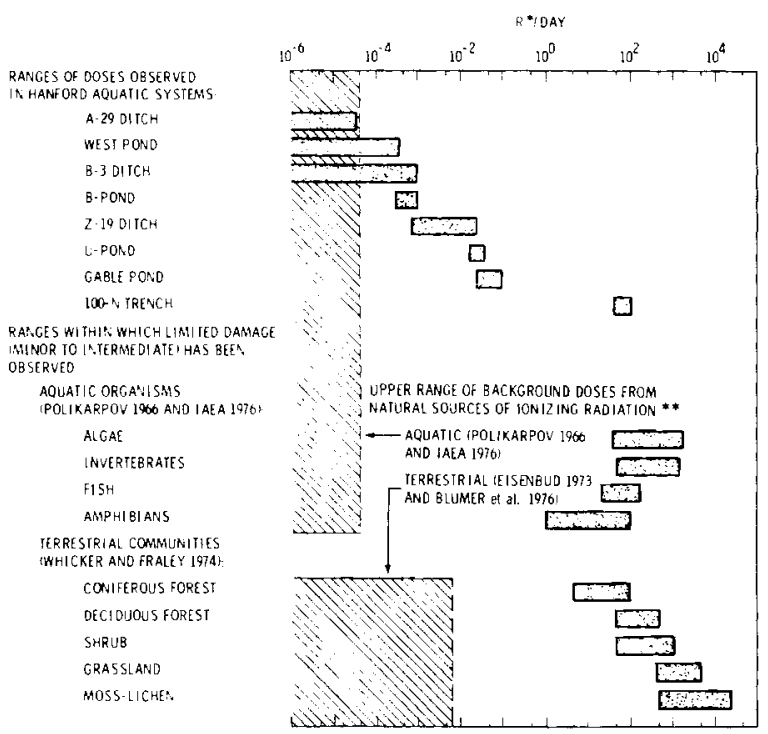

* ASSUME $r a x_{R}$

- oose from iniernal ema tters incluoed. alpha gose excluoed

FIGURE 5.6. A Dose Comparison of lonizing Radiation. 
affected the colonization, diversity, and activity of biota that appear in them.

Despite this lack of ecological evidence, we have determined that one system (100-N trench) contained enough radioactive material to be potentially harmful to some aquatic organisms and terrestrial communities. However, the biota in this ecosystem did not clearly indicate radiation influence. The organisms existing in the 100- $\mathrm{N}$ trench sediments were common to most smaller freshwater environments and also appear in other Hanford aquatic systems.

Terrestrial Radioecology of Waste Management Areas

\section{Ecological Efficacy of Shallow} Land Burial

Shallow land burial is a relatively inexpensive and safe way to keep low-level radioactive solid wastes from movement by biological vectors. It has been practiced on the Hanford site for more than 30 years. The objective of this study is to record the efficacy of shallow land burial in safequarding biota and to examine the contribution of above-background radiation exposures delivered to animals living in waste burial sites.

The coyote (Canis latrans), badger (Taxidea taxis), ground squirrel (Spermophilus townsendii), pocket mouse (Perograthus parvus), and the harvester ant (Pogonomyrmex owyhee $i$ ) have the ability to penetrate the backfi1 and come in contact with the burial wastes. Harvester ants were recently identified as responsible for bringing radionuclides to the soil surface during nest building activities. Mice have been studied to determine if burrowing animals living on retired waste burial grounds can be exposed to radiation emitted from the burial wastes. Data indicate that in a few instances mice have received greater than background doses, presumably by burrowing underground through fissures in the backfill.

The roots of plant species growing on the backfill may penetrate deeply enough to contact radioactive material. The amount of radioactive material taken into the roots and moved into the shoots depends upon the species. Rabbitbrush (Chrysothamnus nauseosus), a shrub, has penetrated to a depth of $3 \mathrm{~m}$ to bring 137Cs to the leaves, wood and seeds. Russian thistle (Salsola kali), an annual, has deep roots and has been documented to accumulate $90 \mathrm{Sr}$ and $137 \mathrm{Cs}$. Total amounts of radioactive materials incorporated into plant tissues has been found to be very small, but once radionuclides enter plant tissues they can enter food chains and be carried long distances by animals.
Shallow burial grounds must be designed to prevent biotic transport of radionuclides. Prevention of biotic leakage is more efficient and cost-effective than methods which interrupt the food chain.

Animal Wastes as Indicators of Food Chain Contamination

In order to study food chain contamination, animal fecal matter, food scraps and regurgitated pellets could be routinely collected and analyzed for changing levels of radionuclides. This would decrease or eliminate the need to harvest the animals themselves for study.

A colony of great blue herons is known to exist in Benton and Franklin Counties and is located on the Hanford Site. The colony of approximately 40 pairs in confined to a small isolated grove of black locust and poplar trees on the banks of the Columbia River. The parent birds forage for fish in shallow shoreline waters which they feed to their young. The young birds defecate over the rim of the nest and food scraps dislodged from the nest fall to the ground. Over the nesting season substantial amounts of detritus accumulate on the ground beneath the nest trees. This detritus can be collected, dried and chemically or radiochemically analyzed.

Because herons on the Hanford Site derive most of the ir foods from the Columbia River and nearby nuclear waste process ponds, any biologically available contaminants in the waterways could be expected to occur in the heron detritus and slightly elevated levels of ${ }^{60} \mathrm{Co}$ and ${ }^{137} \mathrm{Cs}$ have been found. These data indicate that heron detritus is a useful and sensitive indicator of food chain contamination derived from aquatic ecosystems.

The coyote feeds on small and large mammals, birds, reptiles, insects, fish, fruit and carrion of all kinds. It roams more or less at will over the Hanford Site, including the waste management areas. Coyote scat can be routinely collected, dried and radiochemically analyzed. Only a few data are presentiy available concerning radionuclide content of coyote scats. However, scat collected in and near the waste management areas has slightly higher levels of $90 \mathrm{Sr}$ than those from other parts of the Hanford Site. This suggests that coyote foods obtained from the waste management areas have higher levels of $90 \mathrm{Sr}$ than foods obtained elsewhere on the Hanford Site, indicating that low levels of environmental contamination exist and are available to coyotes through their diet. Continued surveillance will be necessary to detect increases or decreases in contamination as radioactive materials are managed in future years. 
Hawks and owls are high-trophic-level organisms. These animals mainly hunt and eat small mammals, small birds, snakes, 1izards and grasshoppers. The Swainson's hawk is present between April and September throughout the Hanford Site and the horned ow 1 is a year-round resident. These hawks and owls, after feeding, regurgitate pellets comprised of hair, feathers, bones, and other nondigestible animal materials. These pellets can be found scattered around nest sites or perching sites. Pellets can be chemically analyzed for environmental contaminants and types of food items eaten.

The advantages of collecting scat, pellets and food scraps from high-trophic-level an imals are clear. First, the method is nondestructive. Animals with low population levels need not be hunted and killed. Second, sample collecting can be conducted routinely with little disturbance to animals during the critical breeding or nesting season. Third, sufficient biomass can be collected for accurate chemical analyses, and finally, the relative amount of radioactivity originating from the Hanford Site can be at least partially determined by comparison with detritus from other areas.

\section{Burrowing 0wls Study}

Over the past few decades burrowing ow 1 populations in western grasslands have shown a significant decline. Intensive farming and the eradication of prairie dogs are two factors which have caused the reduction. The Hanford Site, with its history of little human interference, today serves as an important nesting area for burrowing owls. No fewer than 20 pairs breed on the Hanford Site. Since 1975 the owls have been studied to determine the ir habitat requirements, food habits, and productivity of the Hanford population.

\section{Cold-Blooded Vertebrates of the Hanford} Site

During 1976 and 1977 a drift-fence study was conducted to assess the relative abundances of snakes and lizards utilizing four different vegetational associations on the Hanford Site. Pit trapping in a grid arrangement was also utilized to study populations of lizards. To date we have analyzed 58 lizard stomachs for dietary information and have examined the ir reproductive conditions (number of eggs, size of ovaries or testes). These analyses, when broken down by species, sex, and age and examined spatially and temporally, will provide information on the parameters which function to partition lizards (Uta stansburiana, Sceloponus grociosus) into their respective niches.

\section{Radiosensitivity of the Harvester Ant}

The harvester ant (Pogonomyrmex owyhee $i$ ) frequently seeks out disturbed areas as its habitat. Waste management areas often support a greater density of ant colonies than the surrounding areas. Harvester ant colonies on the Hanford Site have been observed to burrow to a depth of $2.7 \mathrm{~m}$, which is within the depth of some low-level radioactive waste sites. The purpose of this study was to determine the radiosensitivity of adult worker harvester ants. Mortality rates and an LT50 (lethal time for $50 \%$ of a population) were used as measures of radiosensitivity.

Ants were collected locally, separated into groups of 30 , and housed in plastic petri dishes. The ants were kept at two different climate regimes: 27C (Series A) to simulate summer and 7C (Series B) to simulate winter. Thirty-four different groups of ants were exposed to a $137 \mathrm{Cs}$ source at exposures ranging from $3.5 \mathrm{kR}$ ( $3.36 \mathrm{krad})$ to $268 \mathrm{kR}(257 \mathrm{krad})$. Following irradiation, the ants were examined daily for mortality and dead ants were removed. It was impossible to tell live from dead ants in the Series B groups because of their lack of movement. Therefore, this series was not counted until 30 days after irradiation, at which time their ambient temperature was raised to $27 \mathrm{C}$. Mortality rates were compared between the two temperature treatments. In addition, the LT50's were interpolated from mortality curves to further quantify the relationship between exposure and survival time.

The mortality rates of both series increased as the exposure was increased. There did appear to be a latency period for the Series $B$ group, even extending past the 30-day period when the ants were maintained at $7 \mathrm{C}$ and were not observed. However, the eventual mortality, as a function of dose, was not different between the two groups; only the amount of time from irradiation to death was different.

\section{Biotic Transport Parameters}

\section{Uptake and Distribution of Uranium-232} in Peas and Barley

Breeder reactors that use 232 Th to breed fissile $233 \cup$ may play an important role in meeting the nation's energy requirements. Irradiation of $232 \mathrm{Th}$ also results in the formation of $232 \mathrm{U}$.

Certain properties of $232 \mathrm{U}$ could be potentially dangerous if released to the environment. The decay chain for $232 \mathrm{~V}$ contains six alpha- and two beta-emitters. 
Included in the decay series is 208Tl which emits a 2.6 MeV gamma. Uranium-23? has a half-life of 72 years and decays by emitting a $5.3 \mathrm{MeV}$ alpha particle to $228 \mathrm{Th}$, which has a 1.3-year half-life. The remaining offspring in the decay series have half-lives shorter than 3.5 days, and therefore are effectively in equilibrium with 232u within 10 years following chemical separation of uranium from the irradiated fuels.

Most environmental studies concerning uranium have been related to $238 \mathrm{U}$ and its proximate risks to human health. Most biological hazards associated with uranium are related to the chemical toxicity of the element rather than radiological implications. However, 232U having a relatively high specific activity, presents new potential radiological hazards previously ignored when considering the biological effects of uranium. This study is concerned with the transfer of 232U from soil to peas and barley plants.

Concentration ratio (CR) values listed in Table 5.5 were determined by dividing the level of $232 \mathrm{U}$ observed in the vegetative material (dpm/g oven-dried tissue) by the soil concentration $\left(1.5 \times 10^{4} \mathrm{dpm} / \mathrm{g}\right.$ ovendried soil). Estimates for other plant components were calculated by numerically combining various plant part CR values within each pot which were weighted according to the mass of each fragment. Also included in the table are data on the amount of vegetation produced per pot, along with the ratio of oven-dried weight to harvest weight. One can convert the $C R$ values listed to a harvest weight basis (dpm/g harvested vegetation (Jpm/g dry soil) by multiplying by the dry weight to harvest weight ratio for each respective plant part.
The average CR values for pea plant part analyzed, the leaves, stem/pod and seeds, were $1.7^{\circ} \times 10^{-2}, 3.3^{2} \times 10^{-3}$, and $5.4 \times 10^{-5}$, respectively. The $C R$ value for the stem/pod plus leaf component averaged $7.3 \times 10^{-3}$ and $4.5 \times 10^{-3}$ for the entire aboveground plant. The average CR value for the barley stem/leaf component was $3.5 \times 10^{-3}, 1.5 \times 10^{-4}$ for the seeds, and $2.3 \times 10^{-3}$ for the combined aboveground plant parts.

In general, the peas took up more of the $232 \cup$ than the barley did. The average $C R$ value for the entire aboveground pea plant was approximately twice the barley estimate. An exception was the barley seeds where the $C R$ value was about three times greater than the pea seeds.

The low concentration of $232 \mathrm{U}$ in the seers of the peas and barley is interesting. In many dose assessment models the CR values utilized are of ten calculated using the entire aboveground $\mathrm{pl}$ ant parts. The CR value listed in a guideline for utility companies for estimating radiation doses from operating nuclear power reactors is equivalent to 0.01 when converted to a dry weight basis for comparison with results from this study. This is approximately equal to the CR value for the pea leaves; however, it exceeds the other plant fragments considerably. As illustrated in this study, the CR values for the pea and barley seeds were 83 and 14 times less, respectively, than the entire aboveground plant parts. If seeds were the source of contamination, these differences would be reflected in a dose assessment model and the resulting prediction would be proportionally high. However, in using these data as a parameter for predicting levels of contamination ingested by foraging animals the CR values for the entire aboveground plant would be used.

TABLE 5.5. Uptake of ${ }^{232} U$ from Soil by Peas and Barley Plants.

\begin{tabular}{|c|c|c|c|c|c|c|}
\hline \multirow[b]{2}{*}{ Plant Part } & \multicolumn{2}{|c|}{$\mathrm{CR}=\frac{\mathrm{dpm} / \mathrm{g} \text { dry vegetation }}{1.4 \times 10^{4} \mathrm{dpm} / \mathrm{g} \text { dry soil }}( \pm \mathrm{SE})^{(\mathrm{a})}$} & \multicolumn{2}{|c|}{$\frac{\mathrm{g} \text { dry vegetation/pot }}{( \pm \mathrm{SE})(\mathrm{a})}$} & \multicolumn{2}{|c|}{$\begin{array}{l}\text { Oven } \\
\text { Dry Weight to Harvest } \\
\text { Weight Ratio }( \pm \mathrm{SE})(\mathrm{a})\end{array}$} \\
\hline & Peas & Barley & Peas & Barley & Peas & Barley \\
\hline Leaves & $(1.7 \pm 0.7) \times 10^{-2}$ & & $3.6 \pm 0.1$ & & $0.51 \pm 0.03$ & \\
\hline Stem/Pod & $(3.3 \pm 1.4) \times 10^{-3}$ & & $8.9 \pm 0.2$ & & $0.24 \pm 0.01$ & \\
\hline Stem/Pod + Leaves & $(7.3 \pm 3.1) \times 10^{-3}$ & & $12.5 \pm 1.0$ & & $0.38 \pm 0.01$ & \\
\hline Seeds & $(5.4 \pm 2.0) \times 10^{-5}$ & $(1.6 \pm 0.3) \times 10^{-4}$ & $7.5 \pm 0.2$ & $13.7 \pm 0.8$ & $0.30 \pm 0.01$ & $0.50 \pm 0.03$ \\
\hline Stem/Leaf & & $(3.6 \pm 0.6) \times 10^{-3}$ & & $23.4 \pm 0.9$ & & $0.71 \pm 0.04$ \\
\hline $\begin{array}{l}\text { Entire Aboveground } \\
\text { Parts }\end{array}$ & $(4.5 \pm 1.8) \times 10^{-3}$ & $(2.3 \pm 0.4) \times 10^{-3}$ & $20.1 \pm 0.3$ & $37.1 \pm 1.6$ & $0.29 \pm 0.01$ & $0.63 \pm 0.03$ \\
\hline
\end{tabular}

(a) $\mathrm{N}=10$ 
Chemical Speciation for Uptake Studies

The objectives of these uranium investigations are 1) to develop preparation methods for defined solutions of complexed and inorganic uranium species for $p l a n t$ and animal uptake studies, and 2) to develop methods of detecting and assaying for the uranium speciation in solutions, plant extracts, and animal tissue extracts.

Based on reported stability constants of salicylic acid and $\mathrm{UO}_{2} 2+\left(\mathrm{K}_{\mathrm{S}}=1012\right)$, and DTPA and $1 \mathrm{JO}_{2}{ }^{2+}\left(\mathrm{K}_{\mathrm{S}}={ }^{2} 10^{15}\right)$, attempts were made to prepare these complexes for increasing the concentration of uranium in plant tissues so that animal feeding studies could be initiated. The salicyclic acid and $\mathrm{UO}_{2}{ }^{2+}$ complex, in the absence of an organic phase immisible with water, could not be temonstrated. However, preparation of the $\mathrm{UO}_{2}{ }^{2+}$ and DTPA complex and characterization by thin-layer chromatography and electrophores is were accomplisined. Plant uptake comparisons with this complex and with $232 \mathrm{UO}_{2}{ }^{2}$ in the nitrate form are currently under way. IJtimately, the uranium speciation in the plant and the effect of the incorporated uranium on the availability to animals will be investigated.

The $232 \mathrm{u}$ tracer a 11 ows the study of uranium at low mass levels but presents unique problems with both storage and analysis. The storage problem comes from the difficulty of shielding the $2.51 \mathrm{MeV}$ gamma of 208T1 which is in secular equilibrium with $228 \mathrm{Th}$. For very 1 arge amounts of $232 \mathrm{U}$, this requires the periodic removal of the 228Th. Three analysis approaches are under investigation. The first is digestion of tissue samples and chemical separation of the uranium from all of the offspring with a final assay by alpha energy analysis. The second is digestion of the tissue samples, electroplating of the total uranium plus offspring, and separating the $232 \mathrm{U}$ by alpha energy analysis. The third method does not require digestion. It employs gamma energy analysis of each sample at least three times over a 90-day period with the final determination of the $232 \cup$ from analysis of the growth and decays curves. A11 methods have drawbacks in cost and sensitivity, but application of the best analysis procedure to specific samples types should give the most accurate and complete information possible.

\section{Uranium Movement within a Soil Column}

Radioactive substances released to the environment are subject to chemical, physical and biological processes which may influence their form, availability and distribution in natural systems. The purpose of this 1 aboratory experiment was to document the vertical displacement of $233 \mathrm{U}$ in soil when subjected to processes that nccur naturally in agricultural soils.

Three lysimeters containing Ritzville silt loam were spiked with $36.6 \mu \mathrm{Ci}$ of $233 \mathrm{U}$ contained in a narrow lens from 10 to $10.5 \mathrm{~cm}$ below the soil surface. Each lysimeter was planted with alfalfa, peas or barley. The lysineter's were irrigated and given nutrients as necessary to maintain vigorous plant growth. Between harvests, the soils were watered and subjected to mild freezing to simulate the regional winter season. The lysimeters were maintained through three cropping seasons and two interin winters before sampling the soil profile.

Sampling consisted of cutting horizontal cores through the sides of the lysineters at depths zhove and below the $10 \mathrm{~cm}$ spiking level. Soil samples thus obtained were sent to an outside laboratory for analys is.

Figure 5.7 shows the semi-logarithmic plot
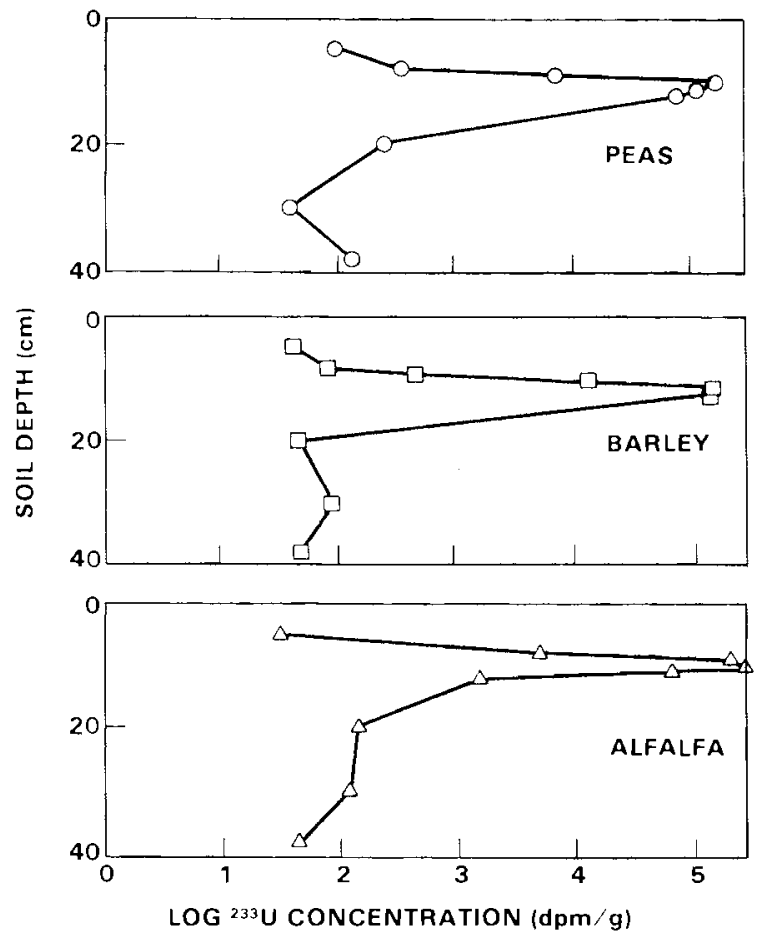

FIGURE 5.7. Concentration of $233 \mathrm{U}$ in Lysimeters at Various Depths Below Soil Surface Following Three Harvests. 
of $233 \mathrm{U}$ concentration versus soil depth. The highest $233 \mathrm{U}$ concentration occurred at $12 \mathrm{~cm}$ soil depth in the barley lysimeter, rather than at $10 \mathrm{~cm}$. This is probably the result of factors other than a mass downward movement of uranium. Watering had made the soil surface uneven, which could have contributed to error in locating the level of the surface. Plant roots may have contributed to an expanded volume of the surface soil and thus increasing the effective depth of the original spiked soil lens. 



\section{- Environmental Behavior and Effects of Technetium-99 and lodine-129}

Investigators: T. R. Garland, R. G. Schreckhise, R. E. Wildung, L. L. Cadwe 11, K. M. McFadden and D. A. Cataldo

The objective of this program is to define the environmental behavior of ${ }^{99} \mathrm{TC}$ and ${ }^{129} \mathrm{I}$, two long-lived radioactive byproducts of the nuclear fuel cycle that have received little study. The specific objectives are to 1) determine the soil physicochemical and microbiological factors and physiological parameters that govern the mobility and bioavailability of different chemical forms of ${ }^{99} \mathrm{Tc}$ and ${ }^{129} \mathrm{I}$ in terrestrial and aquatic environments and 2) validate and measure food web transport in selected field locations.

The potential for both isotopes to exist in multiple valence states and various complex chemical species has been well documented. For ${ }^{129} \mathrm{I}$, the kinetics of equilibration of the source term species with the indigenous iodine pool, or pools, will define its behavior. Unfortunately, these pools are not well defined. Technetium-99 has no stable element pool and its behavior will depend on the chemistries of several analogs and the general physicochemical parameters of the systems. Previous laboratory studies at PNL Have shown ${ }^{99}$ Tc and ${ }^{129}$ I to be much more mobile in the environment and available to biota in ways not previously recognized than the more intensively studied long-lived radionuclides (strontium, cesium, plutonium).

The major obstacle to field studies with both technetium and iodine is the expensive analytical methodology required to analyze the existing environmental levels. For ${ }^{99} \mathrm{Tc}$, the development of a reliable technique for chemical separation and assay by a supporting research program (PNL's Physical Sciences Department; see PNL-2850, Pt. 5) has recently been applied.

Although the research on this program has shown technetium and iodine to be mobile in the environment, adequate assessment of the potential hazards to man requires a more thorough understanding of the mechanisms which may limit technetium effect or reduce the long-term mobility. Research has been initiated in 1) defining the mechanisms of technetium toxicity to plants at the cellular level, 2) evaluating the mechanisms and extent of technetium uptake by aquatic algae and soil microorganisms, 3) determining the chemical form of technetium and iodine in soils, plants and aquatic systems, 4) evaluating the mechanisms responsible for iodine mobility in soil and plant systems and 5) measuring levels of iodine and technetium in soils, plants and animals at specific sites selected for a range of activity and environmental conditions.

These are the major accomplishments of the past year: 1) field sites were located near fuels reprocessing facilities where levels of technetium exist in plant tissues 15 to 600 times the predicted levels due to world wide fallout from weapons testing, 2) kinetic analyses of absorption isotherms suggested that $\mathrm{Tc}_{\mathrm{C}} 4^{-}$was actively absorbed by mechanisms functioning for nutrient ions; analyses of competition kinetics showed $\mathrm{Re}_{4}{ }^{-}, \mathrm{H}_{2} \mathrm{PO}_{4}$ and $\mathrm{SO}_{4}=$ to be transport analogs of $\mathrm{TCO}_{4}{ }^{-}$influencing the transfer of technetium from soils to plants, 3) metabolic 
studies of inhibition of the previously noted phytotoxicity of technetium indicated no pronounced effect on nitrate reduction, photosynthesis or respiration following short-term exposure, 4) transport of technetium in the xylem stream occured as $\mathrm{TCO}_{4}^{-}$, but the technetium deposited in leaves and roots ( $95 \%$ soluble in weak buffers) was shown to be associated yith several ligands with apparent molecular weight $>5000,5)$ availability of technetium in plant tissue to animals was less than $\mathrm{TCO}_{4}{ }^{-}$administered in drinking water, in contrast with plutonium, where incorporation increased availability, 5) concentration ratio of technetium for a single species of algae (Selenastrum) was 2 ?, while several species of bacteria and fungi ranged from 40-170, 7) reduced availability of technetium was demonstrated under simulated irrigatinn practices in contrast to small container growth chamber studies and 8) the release of volatile forms of iodine from soil and subsequent adsorption of gaseous indine by plant foliage was demonstrated and evaluated in terms of impact on the indine cycie.

Mechanisms of Technetium Toxicity to Plants at the Cellular Level

An understanding of the uptake characteristics and subsequent fate of technetium in plants is essential in understanding technetium transfer from soils to plants and $14 \mathrm{ti} i$ mately to man. The plant studies have been designed to investigate three specific areas: 1) the kinetics of root absorption of technetium, ?) the metabolic effects of technetium and 3) the chemical fate of technetium in plants.

Root absorption characteristics of TcO have been extensively studied. These have shown $\mathrm{TCO}_{4}^{-}$to be efficiently absorbed by plants over the concentration range of 0.03 ppt to $80 \mathrm{ppb}$. Kinetic analysis of absorption isotherms suggests $\mathrm{TCO}_{4}{ }^{-}$to be actively absorbed by mechanisms functioning for nutrient ions. Previous sturlies have shown $\mathrm{H}_{2} \mathrm{PO}_{4}^{-}, \mathrm{MoO}_{4}^{2-}, \mathrm{SO}_{4} 2^{-}, \mathrm{IO}_{4} 2^{-2}$ and $\mathrm{ReO}_{4}{ }^{2-}$ to have an inhibiting effect on $\mathrm{TCO}_{4}{ }^{-}$ absorption. Analyses of the competition kinetics of these interfering ions show $\mathrm{ReO}_{4}{ }^{-}, \mathrm{H}_{2} \mathrm{PO}_{4}^{-}$and $\mathrm{SO}_{4}{ }^{2-}$ to be transport analogs of $\mathrm{TCO}_{4}^{-}$and, therefore, should influence the transfer of technetium from soils to plants in the environment.

We are presently using the previously noted phytotoxicity of technetium to identify specific metabolic sites of inhibition, including the nitrate reduction systam and metabolism of nitrogen, carbon and sulfur, and membrane transport processes. Preliminary results show no pronounced effect on nitrate reduction, photosynthesis, or respiration following short-term pretreatment (24 hr).

An understanding of the chemical fate of technetium in plants is required to evaluate the long-terin stability of metaholically incorporated technetium and possible changes in availability of these technetium-containing ligands following ingestion by animals. To determine the distribution and chemical fate of technetium in plants, 36-day-old soybean plants were supplied with a 24-hr pulse of $\mathrm{TCO}_{4}^{-}(9 \mathrm{mM})$ and tissue analyzed after 72 inr. Greater than $95 \%$ of the technetium activity contained in ronts and leaves was associated with soluble materials. Fractionation of the soluble components by molecular weight showed $>70 \%$ of technetium to be associated with ligands with molecular weight $>5,000$. This was in marked contrast to spiked controls which showed an average of only $25 \%$ to be associated with these molecular weights. Thin-layer chromatography and thin-layer electrophores is of the molecular weight fractions showed the presence of a number of ligands containing technetium.

\section{Behavior of Technetium in Aquatic Systems}

Laboratory studies are being performed to evaluate absorption and transport aspects not readily possible in field situations. Presently our studies are concentrating on two EPA algal test species, Selenastrum capricornum and Microcyst is aeruginosa. Both are freshwater species selected because of differences in cell wall structure. Morphological difference may explain the variability in ion "uptake" reported for algal species. Studies with Selenastrum have shown $\mathrm{TCO}_{4}{ }^{-}$absorption to be linear for at least 95 hr from solutions containing 1 ppb $\mathrm{TCO}^{-}$. Accumulation rates for $\mathrm{TCO}_{4}^{-}$are $0.08 \mathrm{ng} \mathrm{Tc} / \mathrm{g}$ dry wt of cells/inr under these conditions. Calculated concentration ratios (Tc activity/g dry wt cells $\div$ Tc activity/ml solution) for cells grown for $24 \mathrm{hr}$ in $1 \mathrm{ppb}$ solution of $\mathrm{TCO}_{4}^{-}$are 22 . Studies with Microcystis are currently under way. 
Behavior of Iodine in the Plant-Soil System

Previous studies of the behavior of $127_{1}$ and $129 \mathrm{I}$ in soils and plants suggested the presence of gas-phase transier of iodine. Laboratory studies were conducted to determine if volatile -I components were formed in the soil-plant sysiem and whether they could significantly affect the environmental transport of iodine. The exparimental system crisisted of Ritzville soil amended with 125 I-, and 25-day-old bushbean plants which were accumulating $125 \mathrm{I}^{-}$during the experiment. 3oth the plant shoots and the root-soil compartments were contained in air-tight containers. Volatile iodine components from these two compartments were passed over control plant canopies and the resultant offgases cycled through a series of gas absorbant traps consisting of activated charcoal, XAD-2, and silica gel. The latter systems were duplicated downstream of an ozonator to oxidize any organic iodine not absorbed in the first pass. of the $125 \mathrm{I}$ - supplied, $0.03 \%$ was released as volatile iodine components; this represented $4,3 \mathrm{pg}$ of the 15,000 supplied over a 14-day period. Of the total released, $0.13 \%$ was absorbed by the plant. canopy over which the air passed and the remainder was trapped to various extents by charcoal and silica gel. The distribution of $125 \mathrm{I}$ on backup absorbed traps suggest that these release rates are minimum values and an unknown fraction of volatile iodine components are passing the traps. These data suggest that there is a gas-phase component in the iodine cycle which has not yet been investigated.

\section{Iodine-129 in the Hanford Environment}

As part of a joint effort with PNL's Environmental Surveillance Program, studies describing the behavior of $129 \mathrm{I}$ in and around the environs of the Hanford Site were begun in January 1973. Samples were collected for evaluating the spatial distribution and relative food chain concentration of 129 I released froin previous fuel reprocessing and other nuclear activity at the Hanford Site. Besides the Hanford Site, samples were collected at Wenatchee, Dayton, and Centralia, Wasinington, and a control site in southcentral Washington. At each sampling location soil, vegetation, litter and plants were collected. Deer were harvested as well. Samples removed from the deer for 129 I analysis included thyroid, muscle, liver and rumen content.

Individual samples were labeled, packaged in double plastic bags and returned to the laboratory where they were immediately frozen. Subsequently, the samples were thawed and aliquots were removed, weighed and freeze-dried. The dried samples were taken to PNL's Physical Sciences Laboratory where they are currently being analyzed for ${ }^{129}$ I content. 

6.0

Nuclear Fusion 


\section{NUCLEAR FUSION}

\section{- Sublethal Effects of Tritium on Aquatic Systems}

\section{- Effects of Lithium and Beryllium on Aquatic Systems}

\section{- Teratogenic Effects of Low-Level Magnetic Fields}

It is highly probable that increased use of nuclear energy will result in greater quantities of potentially harmful radionuclides being released into the environment. This may be particularly true for advanced reactor designs such as the fusion reactor, in which radionuclides, principally tritium, may escape from the plant both in gaseous and liquid effluents in quantities significantly greater than for present Pressurized Water Reactor or Boiling Water Reactor designs. Foreseeing such contingencies, the research program described herein responds to the need to measure the potential radiation effects of tritium releases on individuals, and ultimately populations and biotic communities. As a first approach, our efforts are directed to determining effects of low-level chronic exposures on developing embryo and larval stages, clearly the most radiosensitive.

The anticipated increase in the release of lithium and beryllium from mining, refining, and fabrication of materials used during construction of fusion reactors has also caused concern over potential adverse effects to the environment. Accordingly, FY-1978 fusion-related research has included efforts to study the metabolism of each metal in the living organism, and to determine at what levels toxicity may be expected. Again, the effects of lithium and beryllium will be assessed in embryo and larval stages of selected aquatic organisms, with greatest interest in the response of populations and communities.

Our fusion-related research in FY-1978 also has included preliminary experiments on the effects of low-level magnetic fields. It is conceivable that magnetic fields of 70 to 450 gauss will be encountered by attendant personnel working in the transport and hot cell areas of fusion reactors. Also, those staff members assigned to the areas immediately surrounding the reactor may be exposed for substantial durations to field strengths of 1 to 70 gauss. The current PNL program is aimed at developing different measurement end-points for the early detection of developmental and adult chronic effects. Work involving mammalian tissue and cell systems is reported in PNL-2850, Part 1, Biomedical Sciences; work involving nonmammalian animal systems is reported here. Dr Dennis Mahlum is coordinator for the comprehensive program. The approaches described here study the embryo and larval stages of aquatic organisms. This should provide meaningful data applicable to ultimate assessment of effects in life processes of higher vertebrates. 



\title{
- Sublethal Effects of Tritium on Aquatic Systems
}

- Effects of Lithium and Beryllium on Aquatic Systems

\section{- Teratogenic Effects of Low-Level Magnetic Fields}

\author{
Principal Investigators: R. M. Emery and J. A. Strand \\ Other Investigators: M. P. Fujicara, J. C. Montgomery \\ and T. M. Poston \\ Technical Assistance: C. S. Abernethy, D. C. Klopfer \\ and W. G. Woodfield
}

Continuing studies of the sublethal effects of tritium on freshwater species are directed to determine the potential for genetic transmission of suppressed immune competence to offspring from parental rainbow trout (Salmo gairdneri) exposed to tritium oxide (0, 0.04, 0.4, 4.0, 40.0 rads) over embryogenesis. Another fusion-related research project focuses on the potential adverse effects of the metals lithium and beryllium on aquatic systems. Studies now under way include an evaluation of the potential toxicity of lithium on early life stages of the rainbow trout and the effects of lithium on Columbia River periphyton communities.

Additional fusion-related research has included assessment of effects of low-level magnetic fields on a representative vertebrate. Again, the embryological life stages of the rainbow trout are employed. Particular interest is in the immediate effects of inhibited fertilization, delayed or arrested development, and inhibition of hatching.

Sublethal Effects of Tritium on Aquatic Systems

Current studies are directed to determine the potential for genetic transmission of suppressed immune competence to offspring from parental rainbow trout sublethally exposed to tritium as tritium oxide $(0,0.04$, $0.4,4.0$ and 40.0 rads) over 21 days of embryogenesis. Previously, it was demonstrated that the primary immune response of parental fish was significantly suppressed and permanently altered at doses as low as 4.0 rads.

offspring of each parental test cross (all test crosses were conducted within respective treatments) at five months of age were intraperitoneally administered a heat-activated antigen, Flexibacter columnaris. One week before vaccination, three weeks after vaccination, and at bimonthly intervals thereafter, a standard tube agglutination test for the specific antigen of vaccination was performed on the serum from 20 fish from each of the control and treatment test groups. Additional agglutination tests were performed at binonthly intervals when offspring were 12 months old.

Table 6.1 shows the arrangement of test groups in three ponds employed during the present series of experiments. Each test group is replicated three times. The experiment was designed so that the data could be treated by analysis of variance. Mean titer values (reciprocals) for specific agglutinins to $F$. columnaris for a selected experimental group over the initial 11-week sampling period following antigenic stimulation are presented in Figure 6.1.

Although summary statistical information is not yet available, these data suggest that, under prescribed experimental conditions, a clearly observable change in mean titer values occurred during the 11 -week sampling period following antigenic stimulation. These data also suggest the failure to detect 
TABLE 6.1. Arrangement of Test Groups in Trough or Concrete Pond Array. (a)

\begin{tabular}{cccc} 
& \multicolumn{3}{c}{ Trough or Concrete Pond } \\
\cline { 2 - 4 } Compartment & I & II & III \\
\cline { 2 - 4 } 1 & B & E & D \\
2 & D & A & B \\
3 & C & D & A \\
4 & E & B & C \\
5 & A & C & E
\end{tabular}

(a) The letters $A, B, C, D$ and $E$ represent, respectively, $0,0.04,0.4,4.0$ and 40.0 rad levels of parental test groups.

clear differences in mean titer values among the five groups of offspring at each sampling, which may indicate that suppressed inmune competence as mediated by early radiation injury was not genetically transmitted.

The purpose of FY 1979 studies is to include provisions for determining the relative biological effectiveness (RBE) for tritium applying the radiosensitive immune process of rainbow trout.

Ecological Effects of Lithium and Beryllium on Important Aquatic Organisms and Associated Communities

Mainly because of the requirements of advancing fusion technology, demands for lithium and beryllium will increase severalfold over the next three to five decades. By the year 2000, demands for lithium will increase by a factor of 4 or 5 and demands for beryllium will double. The present demand for lithium of $2.7 \times 10^{6} \mathrm{~kg} / \mathrm{yr}$ will increase to $1.2 \times 10^{7} \mathrm{~kg} / \mathrm{yr}$ in the next two decades if the solid blanket concept is applied to the controlled thermal nuclear reactor (CTR) design. Even more lithium will be required if a liquid blanket concept is used. There is $6.9 \times 10^{8} \mathrm{~kg}$ of lithium presently available in rock ores and $4.0 \times 10^{9} \mathrm{~kg}$ in salt lake brines. However, by the year 2030, these resources may be sufficiently depleted to necessitate extracting lithium from seawater where $2.5 \times 10^{14} \mathrm{~kg}$ is available. For at least the next 50 years, the major source of lithium for fusion technology will be brines closely associated with aquatic environments. The maximum beryllium demand for present CTR projections is $1.5 \times 106 \mathrm{~kg}$ (1500 metric tons) per year, which is about the same as the present annual consumption of this metal without a fusion technology.

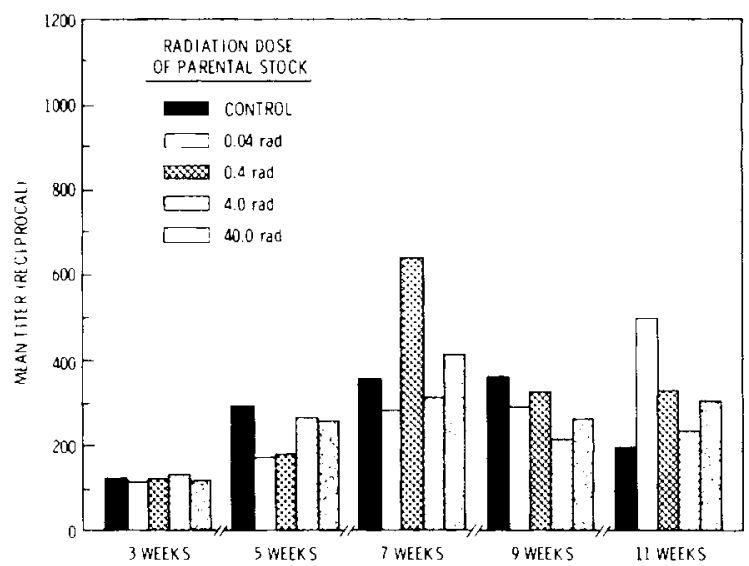

FIGURE 6.1. Mean Titer Values of Offspring in Pond II for Specific Agglutinins to F. columnaris at Each Sampling Interval.

The compounds of lithium and beryllium that could enter aquatic environments from mining, refining, fabrication, and use are prinarily carbonates, fluorides, oxides, hydroxides, and sulfates of both metals. The carbonates and fluorides appear to be the most probable environmental contaminants.

Our literature review indicates a background range from $10^{-4}$ to $10^{-3} \mathrm{mg} / \mathrm{l}$ of concentrations of lithium and beryllium occurring naturally in freshwater. However, concentrations of lithium may be as high as $10^{-1} \mathrm{mg} / \mathrm{l}$ in lakes and streams with somewhat higher salinity, and $10^{1} \mathrm{mg} / \mathrm{l}$ in hot springs and salt lakes. These data suggest a very broad range of background concentrations for lithium (and probably beryllium) covering several orders of magnitude.

The purpose of this study is to strengthen the conceptual understanding of the ecological significance of lithium and beryllium compounds. This study is also designed to identify and measure the acute and chronic effect of lithium and beryllium compounds on specific aquatic organisms and associated freshwater comnunities.

\section{Chronic and Acute Toxicity}

The objective of this task is to determine the concentrations of lithium that cause incipient effects at all life stages of the rainbow trout (Salmo gairdner $i$ ). We have exposed lithium ( $\mathrm{Li}_{2} \mathrm{CO}_{3}$ and $\mathrm{LiF}$ ) to trout in most stages of growth, from egg fertilization to yearling class. The parameters that have been measured are success of fertilization, embryogenesis and hatching, survival of $s a c$ fry to feeding stage, and survival of alevins, juveniles and yearlings. 
Fertilization, embryogenesis, and hatching were observed in recirculating exposure containers. Experimental concentrations of $\mathrm{Li}_{2} \mathrm{CO}_{3}$ were $1,10,100$, and $1000 \mathrm{mg} / \ell$, and test concentrations of $L i F$ were $0.1,1,10$, and $270 \mathrm{mg} / \mathrm{l}$ (saturation). These tests were extended to one week after hatching was complete in the controls. Survivors of these tests were transferred to standard hatchery troughs carrying continuously flowing river water to where the survival of sac fry to feeding stage was observed.

To determine the survival of fingerlings in lithium solutions, we used recirculating systems containing $\mathrm{Li}_{2} \mathrm{CO}_{3}$ and LiF concentrations of $0.05,0.1,0.5,1.5$, and $10.0 \mathrm{mg} / \mathrm{l}$. Exposure time for these tests was $96 \mathrm{hr}$. Adult rainbow trout were also exposed to the concentrations of $\mathrm{Li}_{2} \mathrm{CO}_{3}$ and $\mathrm{LiF}$ in continuously flowing test systems using proportional diluter techniques. These tests ran for 30 days. Fish were examined for tissue damage in addition to mortality.

Although it is too early to draw conclusions from this year's results, there are consistent indications that both $\mathrm{Li}_{2} \mathrm{CO}_{3}$ and LiF acutely affect any stage of rainbow trout development at concentrations as low as 1-10 mg/l. Chronic (long-term) exposure of yearling rainbow trout to $\mathrm{Li}_{2} \mathrm{CO}_{3}$ indicates that effects are manifested at concentrations ranging from 0.5 to $1.0 \mathrm{mg} / \ell$. Add $i-$ tional tests and thorough synthes is of data is the next step in the completion of this task.

\section{Community Response}

This task was intended to detect and measure perturbation from $\mathrm{Li}_{2} \mathrm{CO}_{3}$ and $\mathrm{LiF}$ at the commun ity leve 1 . The target commun ity for this ongoing study was Columbia River periphyton, supplemented with cultures of chironomid larvae and amphipods. These experiments involved the use of two "microcosms" acting as bioassay units for continuously flowing (i.e., single-pass) solutions of lithium in Columbia River water. Retention times in these units were 20 min with a flow of $100 \mathrm{ml} / \mathrm{min}$. Test concentrations for both compounds were $1.0,10$, and $100 \mathrm{mg} / \mathrm{l}$. However, the highest concentration for LiF was $\sim 70 \mathrm{mg} / \mathrm{l}$ (saturation).

These experiments were performed under natural light and at ambient Columbia River temperatures. Indicator parameters measured were total biomass, primary production, autotrophic indices (i.e., Chl a: total biomass), community diversity, survival and growth of specific organisms, and seasonal periodicity of species occurrence (as reflected by control streams).
Preliminary results indicate that the total biomass and primary productivity of periphyton communities are substantially reduced by lithium concentrations greater than $10 \mathrm{mg} / \mathrm{l}$ (Figure 6.2). Detectable effects of lithium on biomass and primary production were observed at concentrations ranging between 1 and $10 \mathrm{mg} \mathrm{Li}^{+} / \mathrm{l}$. There are also tentative indications that the fluoride anion is not additionally toxic to periphyton at most of these concentrations. Additional experimental work, sample analyses, and data synthesis are to be performed in the coming year.
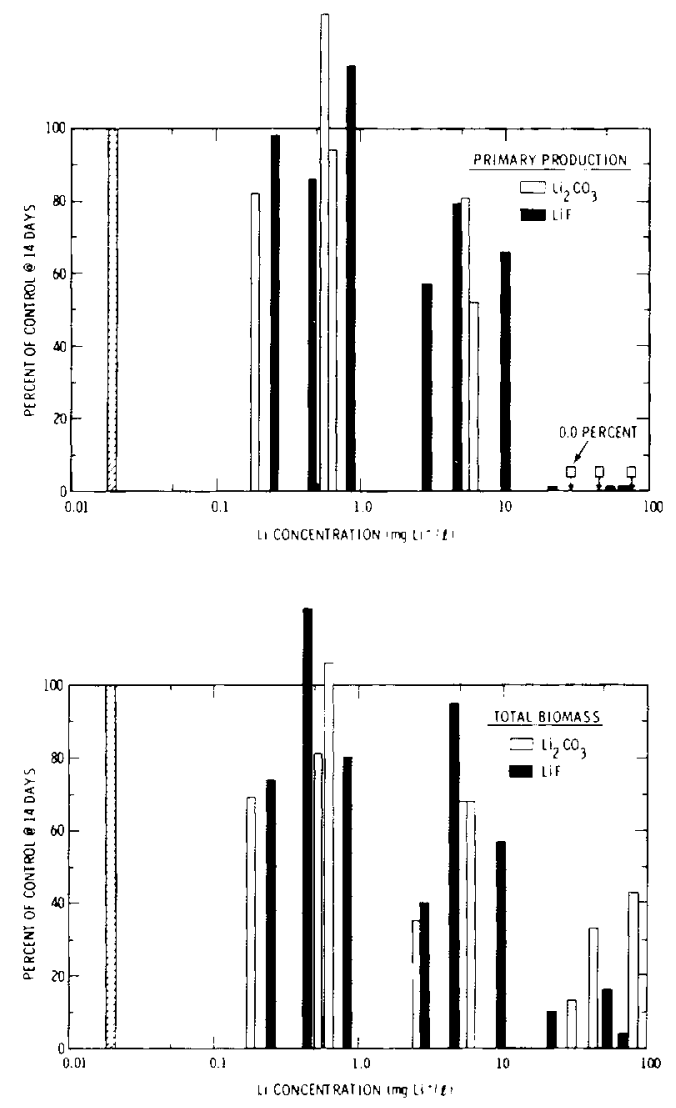

FIGURE 6.2. A Comparison of Primary Production and Total Biomass of Periphyton Communities Occurring in Controls to Those Occurring in Continuously Flowing Solutions of $\mathrm{Li}_{2} \mathrm{CO}_{3}$ and $\mathrm{LiF}$ During August-November, 1978. These communities developed naturally from Columbia River water in $2-\ell$ exposure containers over 14 days.

Teratogenic Effects of Low-Level Magnetic Fields

Development of magnetic fusion reactors will result in occupational exposure of personnel to varying magnetic strengths and geometries. Attendant personnel working in the 
transport and hot cell areas of the reactor could conceivably encounter magnetic fields of 70 to 450 gauss. Also, personnel assigned to the areas immediately surrounding the reactor may be exposed to field strengths of 1 to 70 gauss for substantial periods.

The objective of this cooperative study with the Biology Department is to determine the potential effects of low-level magnetic fields on sensitive life stages of lower vertebrates. Our initial approach is to study the teratogenic effects of magnetic fields on the embryonic life stages of rainbow trout (Salmo gairdneri). Several advantages may be gained by examining magnetic effects on a lower vertebrate. This approach is less costly and will provide large numbers of experimental organisms for meaningful statist $i$ cal analysis. It also permits study of potential latent effects resulting from exposure during embryogenesis. In addition, the data obtained is applicable to processes occurring in higher vertebrates.

To date, four screening tests have been conducted using a Varian Model V-3503 electromagnet. This magnet provided a homogeneous field that could be varied from background to 12,200 gauss. In each test, between 3000 and 7000 embryos were exposed from fertilization through 21 days of development. An additional 3000 to 7000 embryos were maintained outside the magnetic field and served as paired controls. Incubation chambers for magnetic exposed and control embryos were identical (Figure 6.3).

At 21 days (eyed stage), the embryos were transferred to standard hatchery $d r i p$ incubators and they hatched in $28(+1.5)$ days. The fry were transferred to standard

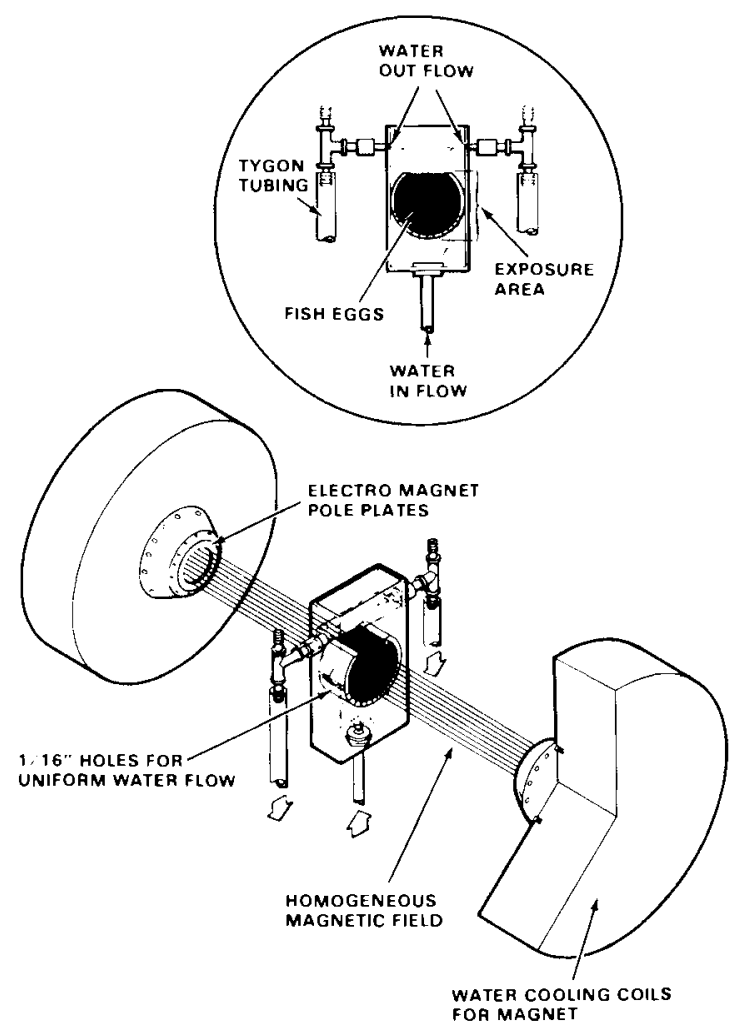

FIGURE 6.3. V-3603 Varian Electromagnet and Plexiglass Egg Incubation Chamber.

hatchery fiber glass troughs two weeks after hatching.

Magnetic field characteristics and environmental conditions for each test are presented in Table 6.2. Although it seemed

TABLE 6.2. Magnetic Field Characteristics and Environmental Conditions.

\begin{tabular}{|c|c|c|c|c|c|c|}
\hline \multicolumn{2}{|c|}{ Test No. } & \multirow{2}{*}{$\begin{array}{l}\begin{array}{l}\text { Intensity, } \\
\text { kilogauss }\end{array} \\
1\end{array}$} & \multirow{2}{*}{$\frac{\begin{array}{c}\text { Duration, } \\
\text { days }\end{array}}{21}$} & \multirow{2}{*}{$\frac{\text { Gradient }}{\text { None }}$} & \multirow{2}{*}{$\begin{array}{c}\text { Mean Temp., } \\
\mathrm{C} \\
11.7\end{array}$} & \multirow{2}{*}{$\begin{array}{l}\text { Mean } \\
\text { D.O., } \\
\text { mg/ }\end{array}$} \\
\hline 1 & (a) Control & & & & & \\
\hline & Exposed & $10.0^{2}$ & 21 & None & 12.0 & 10.8 \\
\hline \multirow[t]{2}{*}{2} & (b)Control & 1 & 21 & None & 11.5 & 11.3 \\
\hline & Exposed & 10.1 & 21 & None & 11.5 & 11.3 \\
\hline \multirow[t]{2}{*}{3} & (c)Control & 1 & 21 & None & 12.3 & 12.6 \\
\hline & Exposed & $2.9-11.8^{3}$ & 21 & None & 12.2 & 12.6 \\
\hline \multirow[t]{2}{*}{4} & (d) Control & 1 & 21 & None & 11.9 & 12.7 \\
\hline & Exposed & $10.1^{4}$ & 21 & None & 12.0 & 12.7 \\
\hline
\end{tabular}

\footnotetext{
(a) Background

(b) Magnet was shutdown for $4 \mathrm{~min}$ on day 12 due to cooling system malfunction.

(c) Magnet was operated in ramping mode; period of oscillation was $1 \mathrm{~min}$.

(d) Magnet was shutdown for 4 min on days 8 through 12 to simulate conditions of Test No. 1.
} 
practical to emphasize the use of fields of less than 450 gauss, the selection of an initial 10,000 gauss field was made to more fully define the experimental system, and ulimately to establish a dose-response relationship. Tests 3 and 4 , in which the magnet was oscillated (ramped) or simply shut down for short periods, were designed to simulate field characteristics encountered in Test 1.

Each test axamined the immediate effects of inhibited fertilization, delayed or arrested development, and inhibition of hatching. Additionally, survivors of each magnetic exposure and paired controls were maintained for 10 weeks after hatching to observe latent mortality and impaired growth.

A chi-square test statistic was applied to each index of effect to determine the potential for differences between exposure and paired control groups. Evaluation of each index was conducted in the "blind" to decrease the possibility of investigator bias.

A partial summary of results from each of the four screening tests is presented in Table 5.3. Although all tests cannot be rigorously compared, a review of these data suggested considerable variation between similar treatments. While a statistically significant inhibition in fertilization occurred in a 11 magnetic treatment groups, a statistically significant reduction in hatching percentage and fry survival over 10 weeks was not consistently demonstrated.

The results of Test 1 are particularly difficult to explain in light of subsequent tests designed to reproduce these initial resulis. However, it is entirely possible that eggs and sperm used in Test 1 were inmature and therefore less resistant to environmental stress. In this case magnetic exposure could have acted in concert with such diminished "vitality" as to account for the degree of effect demonstrated. The eggs and sperm used in Test 1 being the first available during the breeding season, and the finding of relatively unsuccessful fertilization, add credibility to this interpretation.

In FY 1979, after testing at relatively high magnetic field strengths $(10,000$ gauss), tests at lower field strengths $(<5,000$ gauss) will be conducted to fully establish a doseresponse relationship, and to establish the threshold of exposure to produce injury. In FY 1979, tests will also be initiated to investigate the effects of nonhomogeneous (gradient) magnetic fields on trout embryology. Such tests will initially be exploratory but will determine if the effects of a gradient field are different than those of a homogeneous field.

TABLE 6.3. Effect of 10 Kilogauss Magnetic Field on Survival of Early Life Stages of Salmo gairdneri.

\begin{tabular}{|c|c|c|c|c|c|c|c|c|c|c|c|}
\hline $\begin{array}{l}\text { Test } \\
\text { No. }\end{array}$ & Condition & Eggs & $\begin{array}{c}\% \\
\text { Fertile }\end{array}$ & $x^{2}$ & Level & $\begin{array}{c}\% \\
\text { Hatch }\end{array}$ & $x^{2}$ & Level & $\begin{array}{l}\% \text { Survival } \\
10-\text { Weeks }\end{array}$ & $x^{2}$ & Level \\
\hline \multirow[t]{2}{*}{1} & Control & 7171 & 69.88 & - & - & 92.36 & - & - & 87.44 & $\ldots$ & 一 \\
\hline & Exposed & 5721 & 63.46 & 49.43 & (a) & 46.87 & 2177.81 & (a) & 67.01 & 344.35 & (a) \\
\hline \multirow[t]{2}{*}{2} & Control & 4589 & 91.46 & - & - & 95.20 & - & - & 89.47 & - & - \\
\hline & Exposed & 4646 & 89.88 & 6.60 & (b) & 96.34 & 6.49 & (b) & 91.86 & 13.06 & (a) \\
\hline \multirow[t]{2}{*}{3} & Control & 2948 & 85.38 & - & - & 97.57 & - & - & 90.26 & - & - \\
\hline & Exposed & 2844 & 77.02 & 63.03 & (a) & 97.45 & 0.07 & (c) & 88.82 & 2.40 & (c) \\
\hline \multirow[t]{2}{*}{4} & Control & 2686 & 86.40 & - & - & 97.81 & - & - & 92.30 & - & - \\
\hline & Exposed & 2639 & 79.95 & 37.32 & (a) & 98.24 & 1.00 & (c) & 90.23 & 5.52 & (b) \\
\hline
\end{tabular}

(a) Significant $X^{2}$ at 0.001 leve

(b) Significant $X^{2}$ at 0.05 level

(c) Nonsignificant $X^{2}$ at 0.05 level 



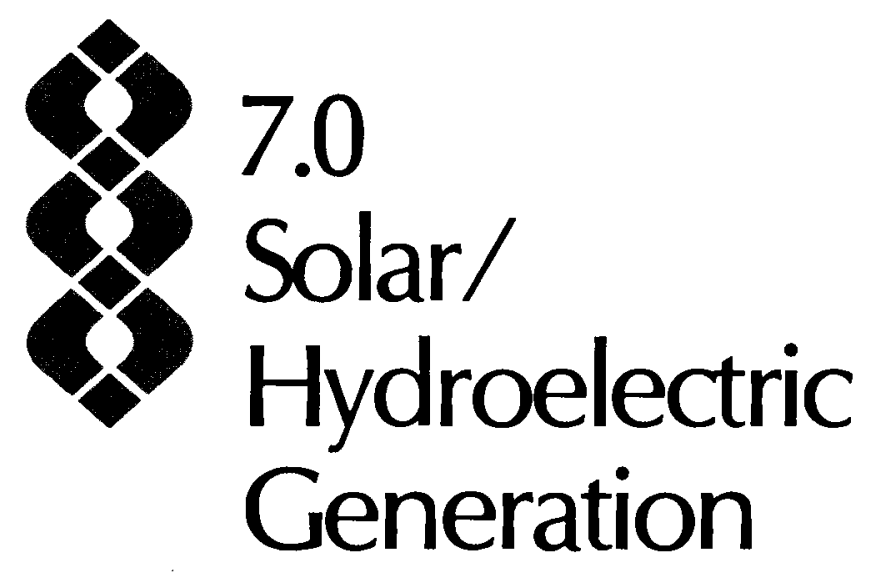




\section{SOLAR/HYDROELECTRIC GENERATION}

\section{- Effects of Hydroelectric Generation on Riverine Ecology}

The use of hydroelectric generation to meet peaking loads has increased in the Pacific Northwest in recent years. This increase has resulted in greater hourly fluctuations in flow volume and subsequent impacts on the stability and dynamics of riverine ecosystems. The trend toward peaking hydrogeneration will continue as more thermal plants are completed and take on a larger share of the regional power base load. In addition to thermal plants, large pumped storage plants are expected to be authorized and constructed in the next decade. They are likely to contribute considerably to the overall daily fluctuation in river flow. Out-of-stream water uses (irrigation, industry, power plant cooling) tend to increase the damage done to aquatic biota by dam-induced flow fluctuations.

The project described here is primarily an ecological field study dealing with the effects of water level fluctuations on important fish species and invertebrate organisms. We have observed several effects of water level manipulation including entrapment and subsequent loss of fry of a number of fish species, including chinook salmon and smallmouth bass; poor hatching success of bass eggs; and stranding of fish food organisms. Our recent studies were initiated to quantify these effects. We are also planning to examine the impacts on chinook salmon redds and to investigate the effects on smallmouth bass recruitment.

The general public recognized only recently the limited nature of regional water resources and the need to resolve conflicting water use demands. Recreational and commercial fishing are important to Pacific Northwest residents who are concerned about the effects of consumptive and nonconsumptive water use on fish production. Sport fishing groups and regulatory agencies have expressed a continued interest in the progress of this report. 
. 


\section{- Effects of Hydroelectric Generation on Riverine Ecology}

Principal Investigators: C. D. Becker, D. H. Fickeisen, R. H. Gray and J. C. Montgomery

NORCUS Appointees: J. M. Haynes, A. D. Sharrett and $R$. K. Werberig

Investigations continued on the effects of short-term fluctuations in water level below hydroelectric facilities. These investigations emphasized quantifying the impact of entrapment on salmonid fry, subsequent salmonid fry mortality, impacts on smallmouth bass (Micropterus dolomieui) reproduction caused by fluctuations in temperature and water level in their spawning areas, and entrapment of bass fry. Adult bass movements were studied by dart-tagging and soliciting tag returns from fishermen. Mark-recapture experiments and fishing along standard transects were used to estimate the population size and relative abundance of fish species in impacted inshore areas.

Results of the completed project "Effects of Water Quality Alterations on Fish Behavior" were analyzed and prepared for publication. This project was designed to study behavioral patterns of ecologically or economically important fish in relation to energy development. Experimental data on fish behavior are essential for proper design and operation of new facilities so that potential adverse impacts on aquatic systems may be minimized. Although the work emphasizes hydroelectric generating plants, the results also apply to nuclear and fossil fuel technologies.

Water levels vary daily and weekly below a hydroelectric dam as more or less water is released for power generation in response to load demand. These variations stress components of aquatic ecosystems. This continuing project is designed to assess the effects of this stress on important fish populations in the Hanford reach of the Columbia River. Our emphasis during the past year was on development of methods for quant ifying the effects of entrapment on fry and estimating population abundance. Previous studies of adult smallmouth bass (Micropterus dolomieui) movements were continued.

Monitoring stations were established at White Bluffs Slough and Hanford Slough to continuously record fluctuating water levels. Radio-frequency transmitters were located on the river bottom at each station. The transmitters included pressure transducers and circuitry to send a pulsed signal. The transmitted pulse rate varied with pressure (depth). Receiving gear, a pulse rate decoder, and a recorder were set up on shore. The depth indicated by the pulse signal was translated to horizontal fluctuation or beach exposure area by using survey data of the beach slope and by using data recorded daily from a cable stretched along the beach that measured the water edge position. The recorded daily water level fluctuations sometimes exceeded $2 \mathrm{~m}$ vertically, which corresponded to about $30 \mathrm{~m}$ of beach width at the study sites. Temperature was simultaneously recorded on Ryan ${ }^{\mathbb{B}}$ submersible thermographs for part of the study period.

In order to determine the accuracy of observations in typical dried entrapment ponds, we conducted a series of experiments to determine the recovery rate of fish entrapped in small depressions by receding water. The experiments required release of a known number (200 to 500) of rainbow trout fry into ponds filled with water pumped from the river and counts of fry remaining after the pond dried. Replicate experiments were conducted in each of several substrates (i.e., sandy, muddy, rocky and grassy). Temperature and dissolved oxygen were measured and recorded in the entrapment ponds. The results indicated that both factors cause mortality in entrapped fish. 
When predators were excluded, the recovery rates were from about $50 \%$ to over $95 \%$. Initial attempts to determine predation rates were unsuccessful, although we believe predation to be high in natural entrapment ponds. Predation of entrapped fish by insects, rodents, birds and mammals has been observed in areas periodically inundated and exposed by changing water levels.

Data for estimation of population size were collected for smallmouth bass and salmonid fry with standard mark-recapture methods. The returns of dart-tags for adult bass trapped in F-Area Slough over the winter were sufficient to estimate the size of this population, which is closed (except to natural mortality). Spray-dyeing methods using fluorescein dye were adapted and a black-light viewing box was developed for field use. Salmon fry were spray-dyed and released in sloughs, but marked returns were very few, indicating that the population was large and transitory. Data on catch per unit effort were also collected for all species taken in standard transects by using a backpack electroshocker, a boat-mounted electroshocker and a seine net. These data will be used to determine relative species abundance and changes in species composition with time.

Studies of adult bass movement and behavior continued with analys is of data from radiotelemetry studies conducted in FY 1977. Dart-tagging of adult jass continued, and we now have over a $10 \%$ return on tagged fish over a three-year period. The results from these studies are consistent with the hypothesis that bass from over $60 \mathrm{~km}$ of the Columbia River spawn in slough areas of the Hanford Reservation.

Observations of smallmouth bass nesting and guarding, and of numbers and relative size of pods of "black-fry" continued. Results were consistent with the hypothes is that temperature fluctuations in the sloughs, caused by variations in river flow, adversely affect reproductive success of smallmouth bass. However, we do not know how densitydependent mortalities may compensate for the effect on hatching and subsequent losses due to entrapment and, therefore, we cannot predict the effect on recruitment to the adult stock.

The project also supported completion of a doctoral dissertation by J. M. Haynes on the relationship between dissolved gas supersaturation generated by hydroelectric dams and the swimming depth of adult chinook salmon migrating upstream. Additional results of this radiotelemetry study were published in the open literature, submitted for publication, and reported at scientific meetings.

Studies to monitor seasonal location, distribution, and movement of white sturgeon (Acipenser transmontanus) in the Hanford reach of the Columbia River were terminated in early FY 1978. These studies investigated radiotransmitter-tagged sturgeon in a freeflowing section of the Columbia River influenced by two hydroelectric dams and thermal loading from a nuclear power plant. The results of the studies were prepared for publication.

Use of pumped storage is likely to increase in the United States, and the U.S. Army Corps of Engineers has been conducting a preliminary site selection study for development of pumped storage systems in the Pacific Northwest. Some of the candidate sites are located on the Columbia River, and development of them would result in removal and return of large quantities of water on a daily cycle. Such a large-scale manipulation of river flows would effect present river flow fluctuations and would probably impact migrating anadromous species as well as other aquatic organisms. We have completed a review of environmental effects and research needs related to pumped storage hydroelectric generation and are drafting a report for publication. Our review demonstrated that comprehensive studies have been conducted at pumped storage sites. Several questions remain to be addressed in order to predict the overall impact of pumped storage development on aquatic ecosystems and to provide criteria for operations management that will optimize multiple use of the reservoirs. As a result of that review we are currently developing a research plan. 
8.0
Satellite
Power Systems 


\section{SATELLITE POWER SYSTEMS}

\section{- Investigation of Microwave Effects on Terrestrial Ecosystems (Proposed)}

The Department of Energy (DOE), in cooperation with the National Aeronautics and Space Administration (NASA), is currently conducting a concept development and evaluation program for the Satellite Power System (SPS). A major portion of this program is devoted to assessment of the environmental effects of employing the SPS concept. The transmission of energy from orbiting satellites to earth via microwaves would expose significant portions of the biosphere to potentially hazardous levels of non-ionizing radiation. PNL is participating in studies of possible radio-frequency interference (Part 3, Atmospheric Sciences) and biological effects of microwaves at the SPS frequency (Part 1, Biomedical Sciences) and the laboratory has conducted some planning studies related to the ecological effects of the microwave beam. The possibly harmful effects of microwaves from radar, communications, and other familiar sources have been studied for the past 25 years, but no studies have yet attempted to assess the impacts of microwave irradiation on the structure and function of intact ecosystems. Impacts on whole ecosystems are of special importance to the SPS concept since an area in excess of $125 \mathrm{~km}^{2}$ would be continuously irradiated at each receiving-antenna facility.

During 1978, PNL began conceptual planning of a research design and test facility appropriate to the study of SPS ecological effects. The results of that planning effort are reported here. Further development of this potential program will occur at the request of the SPS Program Office in DOE's Office of Energy Research. 



\title{
- Investigation of Microwave Effects on Terrestrial Ecosystems (Proposed)
}

\author{
Principal Investigators: M. L. Warner, K. C. Davis,
} K. Fox and I.. E. Rogers

The purpose of this proposed study is to identify any changes in organism populations or in whole ecosystems continuously exposed to the microwave frequencies and the power density levels that are anticipated in or near an operating Satellite Power System (SPS) receiving-antenna system. This information is necessary for the environmental assessment of the SPS concept and for planning and locating receiving-antenna sites. The initial planning effort described here confirmed the technical feasibility of constructing an adequate field exposure system and it identified a battery of possible ecological studies that would be carried out using this exposure system. The information to be developed will aid in specifying the extent of buffer zones around the receiving antenna system.

\section{Characteristics of the Field Exposure System}

Ecosystem-level effects can only be identified by the irradiation of a functioning ecosystem of known characteristics. Initial planning efforts have shown that a field exposure system can be built that will simulate key characteristics of an SPS receivingantenna facility. The test area can be irradiated from a single, tower-mounted reflector emitting microwave energy at the expected SPS frequency of $2.54 \mathrm{GHz}$. Power density flux levels, as measured near the ground, will range from a peak of approximately $20 \mathrm{~mW} / \mathrm{cm}^{2}$ to background $\left(<1 \mathrm{~mW} / \mathrm{cm}^{2}\right)$, distributed in an eliptical pattern. The total area irradiated will be 1 to 2 ha. Exposure will be continuous except for short periods required for sampling in the exposure area. The major electronic "hardware" required for this exposure system has been identified and conversations with both suppliers and persons using similar equipment have confirmed that reliable system components can be readily obtained. During preliminary planning we identified a number of safety features, including electronic interlocks, that will be needed to prevent the exposure of research personnel to unsafe levels of microwave energy.

Irradiation of a known ecosystem with microwave energy distribution along gradients of power density will allow the use of a "dose-dependence" research design. In this design, effects are identified by comparing ecologically similar areas receiving differing amounts of microwave radiation. An important advantage of this research design is that it allows conclusions regarding power level effects to be drawn after as little as two years of irradiation. (It would, however, be desirable to continue studies longer to allow for possible emergence of more subtie effects of chronic exposure.) The dosedependence design, however, requires that the entire study site be essentially homogeneous in important environmental variables such as soil, climate, and ecosystem structure. The ALE Reserve is one of the few places where suitable sites have been sufficiently characterized to provide reasonable assurance of such homogeneity. In adrition, the test facility requires a site that is secure, isolated, and accessible to relatively large amounts of electrical power. The ALE Reserve meets these requirements.

\section{Possible Ecological Studies}

A variety of studies can be carried out at the test facility to identify effects on the important components of the ecosystem and on any interactions among these components. The ecosystem components examined may include vegetation dynamics, birds, invertebrates, decomposers, and small mammal populations. In addition, studies on species of special interest can be conducted; specifically, studies on cattle behavior, crop plants, and honey bees. Generally, concern will focus on the possible effects on the behavior, survival, or reproductive success of these ecosystem components and species. Specific candidate studies for each component or species have been identified in the preliminary planning. Studies of abiotic factors such as weather conditions, soil moisture, and soil temperature will also be required. 
An important aspect of the research will be densitometry-dosimetry studies on how incoming power density patterns are modified by site conditions such as vegetation "shadows," reflection, or soil moisture content. This information will be vital in judging which site variables are critical in predicting the effects on ecosystems at other potential receiving-antenna sites.

Densitometry-dosimetry studies will also be valuable in providing a link to SPS laboratory studies of the effects on single organisms. The ecosystem studies described here will identify the presence or absence of effects in an SPS receiving-antenna environment.
They will not identify the physiological mechanisms causing these effects nor identify the complex history of exposure levels experienced by the free-living organisms. Followup laboratory studies will be required to investigate these issues.

Documentation of the Planning Done to Date

Preliminary plans for the proposed investigation of microwave effects on terrestrial ecosystems are more fully described in a technical description of the proposed project, submitted to the SPS program office in August 1978. 
9.0

Multitechnology

and Supporting

Research Programs 


\section{MULTITECHNOLOGY AND SUPPORTING RESEARCH PROGRAMS}

- Analysis of Natural Systems

- Ecological Effects of Combined Aquatic Stressors

- Effects of Energy Systems Effluents on Coastal Ecosystems

- Bioavailability of Energy Effluent Materials in Coastal Ecosystems

- Marine Chemistry of Energy-Generated Pollutants

- In Situ Pollutant Measurements

- DOE-Funded Oceanographic Cruises

- Coordination of West Coast Marine Programs

This section discusses research efforts relevant to several presently operating technologies as well as those being investigated for the future. In these programs the nature of the environmental problem is equally applicable to any one technology; examples would be thermal and chemical water pollution caused by operation of steam electric plants, whether nuclear, fossil fuel, or gas-fired, and the statistical design needed for distinguishing a general background of industrial pollution from the contributions, if any, arising from operation of an energy facility.

The two main types of study in this category include biomathematical effort represented by the first project indicated above, and aquatic ecological studies represented by the remaining seven projects.

The assessment of how a technology will impinge on an ecosystem requires the ability to adequately describe the existing system and then measure the changes (if any) resulting from a technology deployment. The analysis of natural systems has been mainly qualitative in the past and has led to situations where no solid quantitative measure of change could be made even though extremely large and expensive descriptive programs have been carried out. The program addressed in this section focuses on the improvement of sampling methods through the application of sampling theory and new statistical analysis techniques. Through this program we hope to refine the methodologies used in sampling and analysis to permit cost-effective programs to be implemented at specific sites. This will provide statistically valid data 
for determining the level of change resulting from a technologies operation. An important theoretical development has been that of the "ratio" design for measuring environmental impacts. Opportunity to test these concepts has also been provided through related services work for the Nuclear Regulatory Commission as described in Section 11.0 of this report.

The use of the aquatic (fresh and marine) environment by many technologies as a resource and disposal site, and the fact that most contaminants leaving an energy facility (whether as a solid, aerosol, or liquid) eventually enter an aquatic system, requires that we understand how these materials interact with the aquatic ecosystem and the ultimate consequence of their presence. To understand this, it is necessary to know how the aquatic ecosystem functions and the processes and mechanisms controlling the cycling, effects and fate of energy-produced contaminants. Our research has attacked this problem from two points: the understanding of how specific contaminants interact with and affect aquatic organisms; and the understanding of the chemical interaction and the factors that control these interactions. Relative to the biological effects, we have undertaken studies to determine the effects of chronic exposures on basic processes important to the survival of an individual and population. These include behavioral responses important for obtaining food, defending against or escaping from predators, and finding mates for reproduction. Also included are the physiological changes indicative of long-term stress and specific for individual contaminants.

Research on the chemical interactions has focused on defining the form of a contaminant that is "bioavailable," and the physical, chemical and biological conditions that control the quantities of the form present. The two avenues are complementary in that each provides an understanding to why certain phenomenon are observed in the laboratory and field. The results are particularly significant in the assessment of probable effects of deployment of existing and new technologies. 


\title{
- Analysis of Natural Systems
}

\author{
Principal Investigators: _.. L. Eberhardt and J. M. Thomas \\ Technical Assistance: M. T. Cochran
}

The thrust of this project has continued to be development of quantitative theory and improved methods for application to real-world problems. All of the technologies involved in energy programs will clearly impact the environment in some way. Evaluating such effects requires survey and sampling designs besides the capability of actually measuring various characteristics of natural populations. Merely measuring levels of contaminants or abundance of a species, while both difficult and essential, is not in itself sufficient to answer basic questions. Because natural populations have a built-in "regulatory" mechanism, they can at times compensate for some insult so that its impact is not important. In other circumstances a minor environmental change may have very serious consequences. We have thus begun research in this basic hut very difficult area.

\section{Statistical Aspects of Environmental Contamination}

We have continued our investigations in four areas of sampling: 1) descriptive, 2) analytical, 3) sampling for spatial pattern and 4) sampling for modeling. The first two areas have been studied extensively, and most ecological research needs in energy technology areas can be handied by adaptation of existing methods. The other two areas are wholly new in environmental work (having been developed largely in geology and industrial research) and thus need much work for actual application in environmental research. Both theoretical and practical developments are needed, as well as expositions (manuals, etc.) directed towards specific energy technology applications.

We have focused recent efforts on the sampling for modeling problems. This work has been mostiy devoted to computer aspects (i.e., considerable time has been involved in developing programs for a PDP-11/34 minicomputer). Since "optimal sampling" strategy is closely linked to the presumed probability distribution, we are using simulated data from several such distributions (principally log-normal and gama). Because our results will depend largely on the validity of the simulated data, considerable effort has been expended in evaluating uniform random number generators for use on this project. (a) In addition, we plan to "fit" our simulated data using nonlinear least-squares techniques. Four computer codes have been obtained (and are now operational) for this purpose; two do not require partial derivatives. We presented our preliminary results at the Third DECUS Symposium in November.

Biostatistical Aspects of Environmental Impact Analysis

Our previous work on this topic as it relates to nuclear power plants has peen, summarized in three journal papers. $(b)(c)(d)$

(a) Nicholson, P. R., Thomas, i]. M. and Watson, r. R., in press, Characterization of PDP-II pseudo-random number generators; to appear in Proceedings of the Third DECUS Users Society Meeting; Maynard, Massachusetts: Digital Equipment Corporation.

(b) Mckenzie, D. H. and Thomas, J. M., ms. submitted, Towards improved field experimental designs and quantitative evaluations of aquatic ecosystems.

(c)Thomas, J. M., Mahaffey, J. A., Gore, K. L.. and Watson, D. G., in press, Statistical methods used to assess biological impact at nuclear power plants; Journal of Environmental Management 7.

(d) Thomas, J. M. and McKenzie, D. H., submitted, A procedure for assessing biological effects of power plants on fish, to appear in the American Fisheries Society Bulletin, Fisheries. 
Since there is now considerable tebate on biological monitoring (the impetus seens to be from interest in haseline monitoring), we are currently devoting some attention to this general area.

We found that considerable confusion exists regarding the exact meaning of "monitoring." Therefore, we have elected to define biological monitoring as the collection of samples of biota, lsually as a function of time, taken to assess population fluctuations for compliance with regulatory directives, and sometimes taken in an attempt to assign cause from observed effect. We suggest that monitoring for the first two purposes should normally be called baseline monitoring, while sampling to assign cause or answer questions about how much or where it is might be called research (analytical) monitoring. As such our research on sampling will be directly relevant to monitoring problems (as noted above) and in particular to the manv aspects related to baseline monitoring.

An initial appraisal indicates that population data collected as a function of time (baseline) can sometimes also be useful in the impact assessinent contoxt (i.e., cause and effect). Although there are substantial problems (indirect effects, compensation, interactions) it appears to us that some inferences (but not conclusions) can be obtained by correlation of current observations with the long-term trend. Moreover, laboratory results can be evaluated against a baseline data sequence and testable hypotheses may be devised.

\section{Censusing Animal Populations}

Two extensive journal papers concerning this topic were described in last year's report. Both have been completed and published this year (Eberhardt, 1978a,b). One was addressed to the issue of sample size (i.e. how large a sample should be taken in given circumstances). The second deali with transect methods (1ine transects, strip transects, and line intercepts). Analysis of data from a large-scale line transect census made it evident that another facet of the methodology (use of right-angle distances) required further research, so another paper was prepared on that topic, and will appear in the near future. (a) In that paper, we consider a nonparametric approach which we believe will be useful in the improvement of "Emlen's method" for censusing sinall birds, which was shown to have a rather serious shortcoming in our earlier paper.

(a)Eberhardt, I.. I.., Time-transects based on right-angle distances; to be published in Journal of Wildl ife Management.
Most of the available data on animal populations is in the form of what may be called indices or relative measures of abundance. Unfortunately, very 1 ittle attention has been paid to the mathematical and statistical aspects of sucin datz. We have thus begun an analvsis of the situation, portions of which were reported in one of the papers mentioned above (Eberhardt, 1978b).

Mechanisms for Animal Population Regulation

As noted in the introduction to this section, population regulation is a key issue in determination of the actual outcome of some stress placed on a population. Under normal conditions, most atural populations can tolerate an additional mortality induced by, for example, construction and operation of a power plant or fossil-fuel extraction facilitv. In some cases the population may "compensate" (e.g., by an increase in reproductive rate) to the extent that no overall change in abundance occurs. However, if the population is already under stress, a small addition to the burden may have a disproportionately large impact. There is thus an urgent need for research on mechanisins that determine the population's response.

There are several aspects to our study of the topic. One is investigation of the available actual practical uses of models for regulation based on real data, principally from the applied areas of $c$ isheries management and economic entomology. We will emphasize the fisheries area, jecause of its closer connections to "impact" problems. A second feature has to do with assessing the population dynamics of a given species, since it is not possible to say much about mechanisms unless one knows the basic facts of birth and death rates and age structure. A third aspect is evaluating data from detailed long-term studies of species populations of the kinds most likely to be involved in energv-related activities. A final portion of our current work concerns the theoretical aspect. A considerable theoretical literature now exists, much of which is concerned with analysis of differential equation models of population behavior. While we may do some model development of our own, the main effort for the present will concern what might be called a "comparative pathology" of existing models. By this we seek to determine the circumstances in which existing models may be appropriate and useful. Such an investigation depends very much on the previously listed aspects of our study as a basis, i.e., on actual applications such as stockrecruitment curves, on study of population dynamics, and on reanalysis of the results of long-term population studies. 
'Ne began a fairly intensive effort of this kind about two years ago, and have published four papers in 1977-78 dealing with our initial work in this area (Eberhardt 1977 a,b,c, Eberhardt and Siniff 1977)
are in editorial process. $\left(\begin{array}{c}\text { (j) } \\ c\end{array}\right)$

\section{Marine Mammal Studies}

As noted in last, year's report, we have been participating in a number of marine mammal studies in connection with our Antarctic research and 1. . L. Eherhardt's responsibilities as a member of the Scientific Advisory Committee of the U.S. Marine Mammal Commission (the Committee has certain statutory responsibilities under the Marine Mammal Protection Act of 1972). Several of the species concerned are variously involved in energv-related activities (sea otters, manatees and howhead whales being notable examples), while data on other mammals will provide useful input for the population regulation effort. Two papers connected with the

(b) Eherhardt, I.. I.., in press, Determining "optimal" levels for marine mammals, to appear in Proceedings of the International Conference on the Population Dynamics of Large Mammals, ed. C. W. Fowler and T. Smith.

(c) Eberhardt, 1.. L., Chapman, D. G. and Gilbert, J. R. A review of marine mammal census methods; to be published in Wildl ife Monographs.
Antarctic work have been published (Siniff et a1. 1977, Siniff, Stirling and Eherhardt 1378), while several others concerning marine mammals are part of the effort described in the section above on population regulation.

\section{Other Activities}

Considerable effort has been devoted to consulting, reviews for journals and the Office of Health and Environmental Research, and critically evaluating the statistical content of departmental publications.

Dr. Eberhardt has participated in the affairs of both the Colloge of Fisheries and the Center for Quantitative Science at the University of Washington (where he is an Affiliate Professor). Dr. Thomas inas heen elected to the Faculty Executive Committee at the Joint Center for Graduate Study (Richland) and continues to serve as coordinator for the Master's Program in Biology. The program has grown to a point where about 20 students are enrolled each quarter and two students received master's degrees this past summer. These activities are broddening the impact of the biomathematics program on other PNL programs.

Interaction with state and federal groups (i.e., Marine Mammal Commission, Department of Interior, Southwest. Fisheries Center) has continued. A final report from our participation on an International Commission on Radiological Protection committee is expected during FY 197 ? 



\title{
- Ecological Effects of Combined Aquatic Stressors
}

\author{
Principal Investigators: D. R. Anderson and M. J. Schneider \\ Technical Assistance: S. A. Barraclough and M. L. Wolford
}

This program represents two major research areas which were formerly separate projects and are now combined under one title. This combination represents a recognition of the close relationship of the information each is generating. The program titles formerly used were "Effects of Thermal Discharges on Aquatic Biota" and "Combined Effects of Waste Heat and Environmental Factors Acting in Concert."

The former was designed to measure thermal injury, latent and manifest, in fish and other organisms important in aquatic food chains. The latter uses such thermal data to investigate the toxicity of multiple pollutants, including thermal pollution and their combined effect on fish. A key concept emerging from these studies is that of sunergistic effect; i.e., where several pollutants each, at "sublethal" concentrations, act together to cause significant abnormality or death. The use of the combined-effect approach in estimating the toxicity of effluents containing multiple toxicants is more realistic than a single-factor approach.

The Combined Effects of Nickel, Chlorine and Temperature on Rainbow Trout

The combined effects program is designed to quantify the combined action of thermal stress and two chemical pollutants, nickel and cinlorine, on the physiology of rainbow trout (Salmo gairdner $i$ ). These chemicals were selected because chlorine is frequently used as a biocide, and nickel alloys are used in a large percentage of the types of condenser tubing in stoam electric stations. The effect of temperature on the toxicity of these two components is being studied because of the thermal component normally associated with steam electric station effluents.

The combined effects approach is more realistic than a single factor approach in estimating the toxicity of effluents containing multiple toxicants. The objective of this program is to study the interactions and mechanisms of toxic action of nickel and chlorine at several water temperatures on rainbow trout. Acute flow-through bioassays are under way in a modified Mount-Brungs proportional diluter. Isotope tracer studies are also under way with $\mathrm{Ni}$ to follow the pathways and rate of nickel accumulation in rainbow trout.
To analyze the isotope tracer data, a computer-compatible data-handling system was developed. A remote computer terminal was modified to interface with the liquid scintilation counter to record the output on magnetic tape. A FORTRAN program was developed to analyze the data. The program includes a quench curve to correct for sample geometry and counting efficiency, and subtracts the background counts, then calculates the disintegrations per gram of tissue. This system eliminates calculation errors and enables the data to be statistically evaluated and plotted (Figure 9.1) without further data transcription. The system substantially reduces the amount of time from counting to analysis or plotting of the data.

The standard method of wet-ashing fish samples containing $63 \mathrm{Ni}$ tracer has been modified to make the process more efficient. Instead of using a hot plate during digestion a microwave oven is used. This system has reduced the sample digesting time to one third the time of a hot plate method; it has the additional advantage of not burning dry or nearly dry samples.

Preliminary results indicate continued uptake of sublethal levels of nickel spiked 


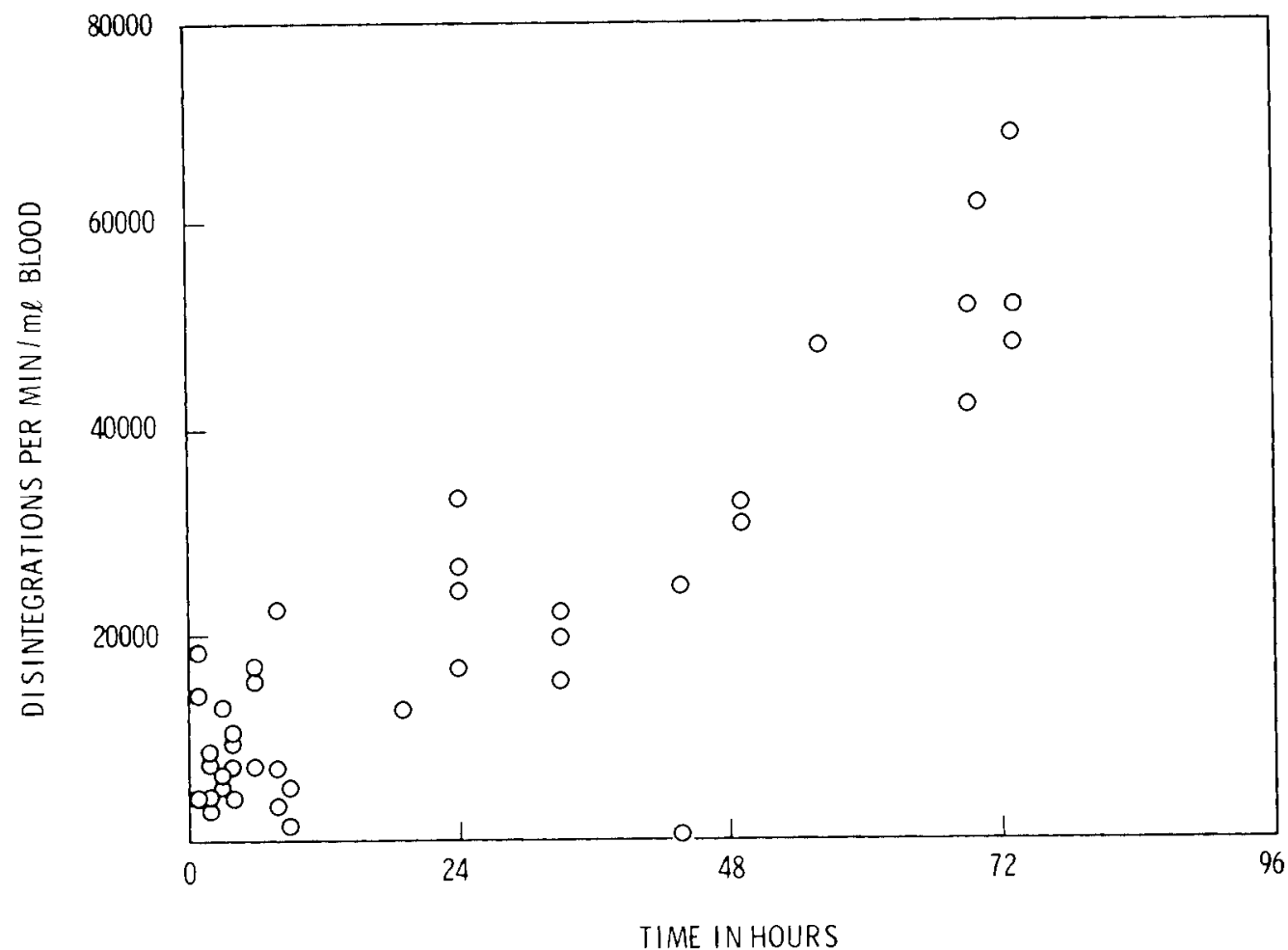

FIGURE 9.1. Accumulation of Nickel in Blood of Rainbow Trout Sampled Over Three Days in Counts per Minute ( $\mathrm{cpm}$ ) of ${ }^{63} \mathrm{Ni}$. Fish were exposed to $6 \mathrm{ppm}$ nickel with an activity of $6100 \mathrm{cpm}$.

with ${ }^{63} \mathrm{Ni}$ in the blood for three liays (Figure 9.1) while excretion of the isotope increases after the second day through the kidneys and lower gastrointestinal track. A comparatively high level of $63 \mathrm{Ni}$ is also accumulated in the eye of fish. Further analyses of the data are continuing.

The experimental design of the acute bioassays is a factorial design with three levels of nickel and three levels of chlorine at different temperatures. This enables statistical evaluation of each toxicant effect and their interaction or the combined effect of the toxicanis and temperatures.

A synergistic toxic effect of chlorine and nickel has been demonstrated. Concentrations of $0.05 \mathrm{ppm}$ total residual chlorine (TRC1) alone result in fish mortality of $5 \%$.

Nicke1, alone, in concentrations ranging from 4-8.5 ppm results in no fish mortality in $96 \mathrm{hr}$. When these levels of chlorine and nickel are combined the resultant mortality ranges from $95-100 \%$ of the fish exposed during a 96-hr bioassay. This is the first incident reported in the literature of a chlorine-nickel synergistic toxic effect.
Effects of Temperature on Fish Stamina Physiology

The investigations discussed in the section were tesigned to determine the combined effects of temperature and exercise stress on fish. Results of earlier studies in this series revealed a combined effect as measured by swim performance and indicators of stress and fatigue level, plasma glucose and $1 \mathrm{ac}-$ tate. The studies conducted this year determined the critical swim speed, plasma glucose and lactate, blood $\mathrm{pO}_{2}, \mathrm{pCO}_{2}$, and $\mathrm{pH}$ of $10 \mathrm{C}$ acclimated rainbow trout (Salmo gairdneri) at $10,15,20$ and $25 \mathrm{C}$.

Critical swim speed (CSS) is defined as the maximum swimming velocity fish can maintain for a precise time period. Determinations of CSS are used to measure the stamina limitations of fish as affected by environmental stressors, e.g., temperature and chemicals. Earlier studies in this series demonstrated that the ability of a fish to swim at water temperatures above the acclimation temperature may be impaired and further suggested that the physiological basis for failure was the development of a hypoxic condition. 
The investigations reported here were designed to quantify the stamina limitations through CSS and to provide the physiological information necessary to explain them.

Rainbow trout were acclimated to $10 \mathrm{C}$. Critical swim speeds were then determined at $10,15,20$ and $25 \mathrm{C}$ in a specially designed swim tunnel. Two fish were introduced into the apparatus at the beginning of each test. one fish occupied the swim chamber and the second fish was held in a chamber receiving continuous water exchange but no current. This fish is therefore referred to as the "resting" fish. After a short handling recovery period water temperature was elevated at $0.5 \mathrm{C} \mathrm{min}^{-1}$ to the test temperature. The water velocity in the swim tunnel was then incrementally increased $0 . ? \mathrm{~m} \mathrm{sec}^{-1}$ at 20 -min intervals. At the instant the rish fatigued, the water flow was interrupted, the time recorded, and both exercised and rested fish were removed from the apparatus. 3 lood samples were obtained by cardiac puncture and from the dorsal aorta for the measurements listed above.

The graphs in Figure 9.2 provide the results for CSS, plasma glucose and lactate, blood $\mathrm{pO}_{2}$ and $\mathrm{pCO}_{2}$ for all test groups. This series of experiments has only recently been completed and not all statistical analyses have been completed. The CSS data was analyzed by one-way analysis of variance and indicates that there is a significant ( $P>0.05)$ difference between the means at the various temperatures. At 250 the CSS is significantly lower than at $10,15,20 \mathrm{C}$, indicating impairment of swimming performance between 20 and ?5C (AT $=10-15 \mathrm{C})$. A combined effect of temperature and exercise stress was noted at a similar $\Delta T$ in the earlier investigations.

The renaining data for plasma glucose lactate levels, blood gases pCO, p0 and for blood $\mathrm{pH}$ have not yet been statistically analyzed. Figure 9.2 provides a plot of mean values. As might he expected, the $\mathrm{pCO}_{2}$ of exercised $\mathrm{fish}$ is higher than that of rested. Regardless of whether the blood samples were taken from the neart or from the dorsal aorta there is also an apparent trend of increasing $\mathrm{pCO}_{2}$ with increasing exposure temperature. Similarly, the blood $\mathrm{pO}_{2}$ is higher in rested $\mathrm{fish}$ at $10 \mathrm{C}$ test temperature as compared with exercise blood $\mathrm{pO}_{2}$. At higher test temperatures the blood $\mathrm{pO}_{2}$ of both groups appears similar in value. Blood glucose and lactate levels appear to follow patterns similar to those seen in earlier investigations. One interesting difference is that the blood lactate of exercised fish appear to be lower for the $25 \mathrm{C}$ test group compared to the $20 \mathrm{C}$ group, whereas the $1 \mathrm{ac}-$ tate levels for the resting fish are more like the patterns observed in earlier studies.
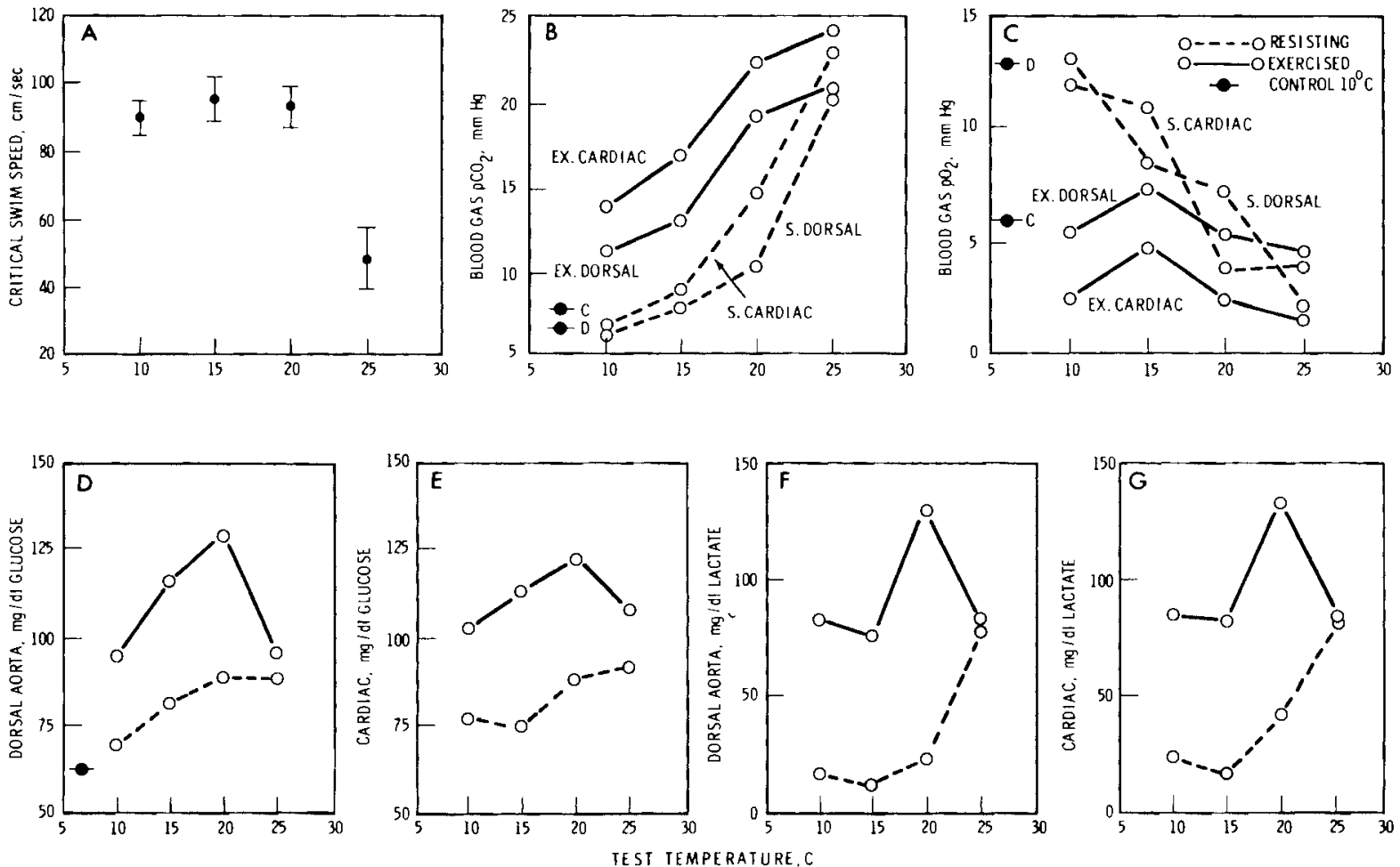

FIGURE 9.2. Critical Swim Speed Mean and its 95\% Confidence Interval at Each Test Temperature. 



\title{
- Effects of Energy Systems Effluents on Coastal Ecosystems
}

\author{
Principal Investigators: G. Roesijadi and J. S. Young
}

This program investigates the potential effects of contaminants released by onergy technologies into the marine environment. Dur primary goal is to identify and evaluate environmentally meaningful measures of the effects which contaminants produced by energy systems have on marine organisms.

At present, a major problem in the study of the pollution effects in the marine environment is the lack of meaningful criteria with which to assess biolngical effects under conditions representing the natural environment. Our research is tesigned to address this problem. In the past year we have studied the effects of two classes of contaminants released by energy technologies, biocides and trace metals (represented by chlorine and copper, respectively), on aspects of the physiology, biochemistry, and histologv of selected marine animals.

Disruption of Magnesium Regulation in the Crab Cancer productus Exposed to Chlorinated Seawater

Disruption of ionic regulation has been reported as a mechanism for the toxic action of chlorinated seawater to aquatic animals. However, research on this subject is scant. For this reason, we studied the effects of chlorinated seawater on ion regulation in the crab Cancer productus, an important species for both sport and commercial fishing. The relationship between ammonia excretion and chlorination was also investigated since reactions with ammonia play z major part in the chemistry of chlorination.

Exposure of Cancer productus to chlorinated seawater altered hemolymph sodium and magnesium concentrations. At the highest chlorination levels, which approached the $96 \mathrm{hr}$ I.C50 ( 1.2 to $1.4 \mu \mathrm{g} / \mathrm{ml}$ total residual oxidants, TRO), regulation of both ions was essentially abolished. Reciprocal changes in the sodium and magnesium levels suggested an effect on the activity of the bladder wall, which has been implicated in the regulation of hemolymph magnesium in crustaceans.

Additionally, exposure to $1.19 \mu \mathrm{g} / \mathrm{ml}$ applied $C l(0.68 \mathrm{\mu g} / \mathrm{ml}$ TRO) for $96 \mathrm{hr}$ resulted in a fourfold increase in the ammonia excretion rate. Crabs also contributed considerable chlorine demand to the exposure seawater. Measurements of TRO in the inhalant seawater and water exiting from the crabs' branchial chambers indicated a reduction in TRO equivalent to $56 \%$ of that initally present in the inhalant water $(0.51 \mathrm{\mu g} / \mathrm{ml}$ TRO).

Measurements of ammonia concentrations in the exposure water indicated that ammonia in seawater was consumed in reactions with oxidants. This was especially evident at higher levels of chlorination. At. $0.58 \mathrm{\mu g} / \mathrm{ml}$ applied $\mathrm{Cl}$ and above, chlorination resultad in near disappearance of ammonia from the water.

Effects of Chlorinated Seawater on the Littleneck Clam

The littleneck clam (Protothaca staminea) is a commercially important bivalve with a range distribution from Alaska to Southern California. These clams occur in the vicin$i$ ty of at least one coastal power plant (Pacific Gas and Electric at Morro $3 a y$, California) and in areas which may be influenced by sewage effluents, both of which use chlorine for disinfection or control of fouling. This clam was used as a test species to determine the possible effects of chlorinated seawater on specific biological parameters. Attention focused on the responses of gills because they have direct contact with the external environment and are considered major organs in gas exchange, uptake of ionic and organic solutes, and ciliary feeding. We measured concentrations of the major gill cations (sodium, potassium, 
magnesium and calcium) since the levels of these ions are dependent on uptake mechanisms associated with the cell membrane. We felt that oxidants present in chlorinated seawater may have a direct effect on the integrity of the cell membranes of gills. We also examined free amino acid concentrations of gills as indicators of alterations in metabolism. Declines in glycine levels have been reported as a response to stress in bivalves by several investigators. Exposures lasted 26 days at concentrations of 25, 75, $150 \mathrm{ppb}$ total residual oxidants (TRO) plus a seawater control. Animals were sampled at 3,14 , and 26 days for ion levels and 0 and 25 days for free amino acids.

We found that gill ion concentrations were not altered by exposure to chlorinated seawater. Mean values for control samples at 0,14 , and 26 days were $575.4 \mathrm{mM} / \mathrm{kg}$ for sodium, $359.1 \mathrm{mM} / \mathrm{kg}$ for potassium, $104.5 \mathrm{mM} / \mathrm{kg}$ for magnesium, and $11.3 \mathrm{~mm} / \mathrm{kg}$ for calcium. Values for exposed clams were not significantly different from controls at any of the time intervals measured. With free amino acid levels, however, we found alterations related to exposure to chlorinated seawater. In particular, glycine declined at all levels of TRO when compared to controls and extibited a correlation with oxidant exposure level. Mean values were $11.72 \mu \mathrm{M} / \mathrm{g}$ for controls, $8.47 \mu \mathrm{M} / \mathrm{g}$ at $25 \mathrm{ppb}$ TRO, $8.05 \mu \mathrm{M} / \mathrm{g}$ at $75 \mathrm{ppb}$, and $5.92 \mu \mathrm{M} / \mathrm{g}$ at $150 \mathrm{ppb}$. These values are consistent with observations made in previous studies, and support the hypothesis that stress in marine animals is associated with a decline in cellular free glycine.

Tissue Copper Levels in Protothaca staminea Exposed to Chlorinated Seawater

Presently, there is controversy regarding the chemical form of heavy metals in seawater in relation to their bioavailability. It has been suggested that the free or ionic form of metals is the fraction available for uptake by organisms. However, complexed forms have also been shown to be taken up across epithelia in bivalves. Since the presence of oxidants in seawater can alter the chemical form of metals by disrupting bonds between metals and complexing agents, we measured "free" and total copper in the exposure water by anodic stripping voltammetry (ASV) and tissue copper levels by atomic absorption in the experiment described previously for the effects of seawater chlorination on Protothaca.

The results indicated no influence of chlorination (25 to $150 \mathrm{ppb}$ TRO) on the gross form of copper in seawater or on the tissue levels of copper after 26 days of exposure. Total copper in seawater ranged from 0.7 to $1.7 \mu \mathrm{g} / \mathrm{l}$ and "free" copper ranged from <0.1 (nondetectable) to $0.3 \mathrm{\mu g} / \mathrm{l}$. These levels reflected ambient copper levels in our seawater system. No relationships were observed with TRO levels in the exposure tanks. I ikowise, copper levels in tissue of chlorineexposed clams did not differ from controls. These results suggested that cinlorine exposure of up to $150 \mathrm{ppo}$ TRO did not alter the ASV-available form of copper in seawater of copper levels in clam tissue. However, addi:ional studies are required for more definitive conclusions. Studies of this sind are presently ongoing on another program at our laboratory.

Assay for Sodium-Potassium Adenosine Iriphoshatase in Gills of Protothaca

In order to directly test for processes related to the functional integrity of the cell membrane of the gills of Protothaca, we began experiments to characterize the enzyme sodium-potassium adenosine triphosphatase (NaK ATPase). This enzyme is localized on plasma membrane and is involved in the cellular regulation of sodium and potassium. characterization involves examining the influence of incubation time, temperature, substrate concentration, magnesium concentration, sodium and potassium concentrations, ouabain (a caridiac glycoside known to inhibit Nak ATPase activicy), pH and cell localization. We have found that the activity of the enzyme is very low in clam gills ( $210 \%$ of total ATPase) and easily masked by the activity of the total ATPase systems. The enzyme appears to he more sensitive to sodium than potassium. Inhibition caused by lack of sodium was equivalent to inhibition by ouabain. In general, however, errors in measurement due to the low activity were very high, and it appears that the $\mathrm{NaK}$ ATPase in clam gills will be difficult to use in hioassays.

\section{Effect of Copper on Eudistylia vancouveri}

We have completed copper exposures to the polychaete Eudistylia vancouveri at concentrations that cause gill degeneration. The purpose was to examine and describe gill necrosis at a range of copper concentrations and compare it with the uptake rate and level of accumulation of copper in the gills. Ten individuals were sampled daily at treatment levels of 0 (control), 10, 15, 20, 40, and $80 \mu \mathrm{g} / \ell$ copper during the first five days and thereafter on days $8,11,15,19,26,33$, and 50. The gills were photographed, examined microscopically for deterioration, and prepared for atomic absorption analysis. Slides were prepared from representatives chosen for histological examination. As an attempt to quantify the amount of deterioration, the dry weight of the entire gill assemblage of each worm (the variable) was recorded to compare with the weight of the eight thoracic segments (the constant). 
At 30 and $40 \mathrm{\mu g} / \mathrm{e} \mathrm{Su}$, gills necrotized within the first? 4 hr of exposure, whereas, at $10 \mu \mathrm{g} / \mathrm{l}$, necrosis was not found until 11 days after the exposure began. Necrosis of the gills usually started at the tips of the more distal pinnules in the lower concentrations and ended with a complete breakdown of the rachis at the higher concentrations. The degree of gill degenzration with time was extremely variable. Within an individual some gills might show considerable necrosis and others little or none. Between individuals, some had most of the branchial plume eroded away and in others most of the plume was intact. In general, though, the severity of degeneration increased with copper concentration. Most of the gill/thorax ratios have yet to be calculated. Histological sections are currently being studied. Control gills have also been examined by electron microscopy in preparation for ultrastructural studies of gill degeneration and lysosomal labilization.

\section{Effect of Copper on the Littleneck Clam}

The effect of copper on the littleneck clam (Protothaca staminea) was tested in a 30-day exposure at total copper levels of 7 , 18,39 and $32 \mathrm{\mu g} / \ell \mathrm{Cu} / \ell$. Controls were treated with seawater alone. Measurements for "free" copper in the exposure water as determined by anodic stripping voltammetry (ASV) indicated that virtually all the copper was in the "free" (as opposed to complexed) form. The complexation capacity for the seawater was determined to be $20.9 \mu \mathrm{g} / \mathrm{l} \mathrm{cu}$. Mortalities during exposure were directly correlated with exposure concentration and were especially severe at 39 and 8 ? $\mu \mathrm{g} / \mathrm{l} \mathrm{Cu}$.

At the end of exposure, copper and zinc content was determined for various organs, and gills were analyzed for acid phosphatase activity and concentrations of the major electrolytes, sodium, potassium, magnesium and calcium. Copper concentrations in tissue increased above control levels in all the copper-treated clams. Gills possessed the highest concentrations of copper at all but the lowest copper dosing of $7 \mu \mathrm{g} / \mathrm{l}$. Zinc levels in tissue did not exhibit anv obvious relationship with tissue copper levels.

When the concentrations of electrolytes sodium, potassium, calcium, and magnesium were determined in gill tissue, an increase in gill sodium above controls was observed at all exposure levels. Other ions did not exhibit such a relationship. The activity of acid phosphatase in gill tissue of exposed clams indicated an apparent induction in enzyme activity since there was an increase in activity with increasing exposure concentration. Since acid phosphatase is considered to be a lysosomal enzyme, the increase in gill acid phosphatase may represent an increase in lysosomal activity as a result of copper stress. 



\title{
- Bioavailability of Energy Effluent Materials in Coastal Ecosystems
}

\author{
Principal Investigators: E. A. Crecelius, C. I. Gibson, \\ L. D. Kannberg, J. E. Rogers and R. L. Schmidt \\ Other Investigators: J. Gurtisen and C. W. Apts
}

The bioavailability program attempts to provide an understanding of the processes involved in the cycling of materials resulting from energy technologies in the marine coastal ecosystem. The primary goal of the program is to be able to predict the fate and ultimate ecological consequences of materials produced by energy technology in the coastal ecosystem. Copper was selected for study because it corrodes in seawater and is a frequent pollutant of marine ecosystems via mining operations, copper paint on ships, copper tubing from power plants, and other sources.

One of the major problems limiting prediction of effects of a contaminant in the marine environment is the inability to equate an analytically defined fraction of the total amount of material in the environment with a biological response. This problem is particularly limiting for long-term effects where chemical modification is likely to occur because of chemical, physical and biological influences. The bioavailability program is using a multidisciplinary research team centered at the Battelle Marine Research Laboratory in Sequim, Washington to address these problems.

This year our work has continued in 1) the development of a method for accurately measuring the "bioavailable" fraction of a contaminant in the marine ecosystem and 2) determination of how natural changes and those induced by energy technology effect the quantities of bioavailable contaminants in the aquatic ecosystem.

During the past year several of our experiments showed that anodic stripping voltammetry (ASV) copper measurements provide a good estimation of "available copper," and that organic molecules play an important role in complexing or detoxifying copper in marine systems.

In two separate experiments we exposed three Northwest marine species, a clam, a shrimp, and a worm, to seawater amended with copper to levels between 5 and $30 \mathrm{ppb}$. In one test, the copper was added to the seawater and the mixture was allowed to age approximately $70 \mathrm{hr}$ before flowing into the exposure tanks. In the other, the copper was added to the seawater and the mixture entered the exposure tank directly. In the aged mixture, the availability (as measured by body burden) was significantly less than in the unaged mixture (Figure 9.3).
In a second series of experiments, sediment was included to create a mixture more similar to the environment and to determine if the presence of sediment would change the availability of copper. Two clam species were used in this test: a filter feeder, Protothaca staminea (the littleneck clam), and a detritus feeder, Macoma inquinata. The test was conducted under static conditions. Results of the test showed that the copper added to the water quickly moved from the water column to the sediment. In the sediment the major portion of added copper was found to be associated with the organic fraction. After one month of exposure, the body burden of copper was measured. The two species responded differently. In the filter feeder, $\underline{P}$. staminea, body burden did not increase; whereas in the detritus feeder, M. inquinata, it did increase. 

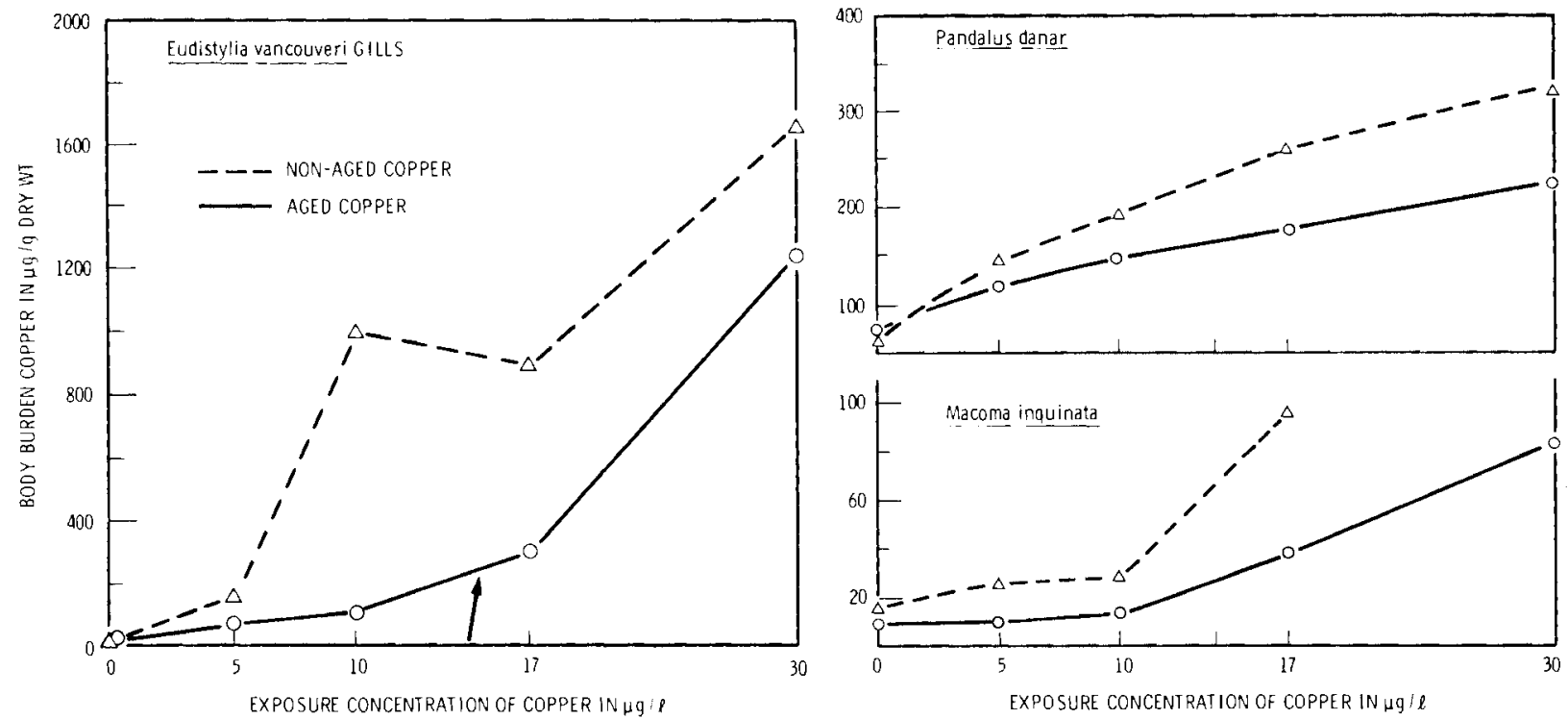

FIGURE 9.3. Body Burdens of Three Marine Species Exposed to Aged and Unaged Seawater, Copper Solutions After One Month Exposure Under Flow-Through Conditions. Arrow indicates the copper complexing capacity measured during experiments.

There are three possible explanations for this difference in uptake: 1) the organisms have a physiological difference that allows $M$. inquinata to be more effective in removing copper from solution, 2) $M$. inquinata removed some copper from the sediment, or,

3) M. inquinata was exposed to more interstitia water which had higher levels of copper. The first explanation is not likely since individuals of both species held above the sediment did not increase in body burden, and when both were exposed to aged seawater/ copper solutions, there were no significant differences in body burden increases. Further research is needed to determine whether organisms are able to strip metals off sediment fractions or if the difference is caused by higher levels of available contaminants in interstitial waters. Research related to the latter question on the quantities of metals in various fractions of the sediment and interstitial waters is discussed later in this section.

An important need is a method of measuring the quantity of "available form" of contaminants present in an energy technology's effluents or caused by operation of the technology. Such a tool will enable accurate prediction of the biological responses that will occur under described conditions. Without such a measure we will need to run bio- assays under laboratory-controlled conditions for every set of conditions and contaminants projected to be released. For the trace metals, we have begun our studies with copper. We have been developing ASV as a way of measuring "available" copper in marine waters. At this time, our data indicates that there is a good correlation between ASV-measured copper and the increase in body burden in the species tested. We believe the ASV-measurable copper is a mixture of free and labile copper, and the amount measured is determined by the complexors present and their relative complexing strength. We have found that Sequim Bay water has a natural complexing ability between 7 and $33 \mu \mathrm{g} / \mathrm{l}$ added copper, with an average for 57 measurements over one year of $19 \mu \mathrm{g} / \mathrm{l}$. When copper is added at these concentrations, or less, we find little ASV-measurable copper and no significant increases in body burden. However, when copper is added in concentrations that exceed the natural complexing capacity, we find increased ASV-measurable copper, and exposed oroanisms begin to have increased body burdens (Figure 9.3).

For Sequim Bay water we found complexing ability to vary randomly. It could not be correlated to tide cycle, sunlight or other such factors. We did find that up to $50 \%$ of the complexing capacity could be removed by filtering the seawater through a $0.4 \mu$ filter. 
Cooperating with Dr. Allen Lewis of the University of British Columbia, we measured the vertical distribution of complexing capacity in $500 \mathrm{~m}$ of water. There appears to be a significant decrease in complexing capacity near the surface when compared to deep water (Figure 9.4). Further work is needed to determine how real this fistribution is and any causitive factors.

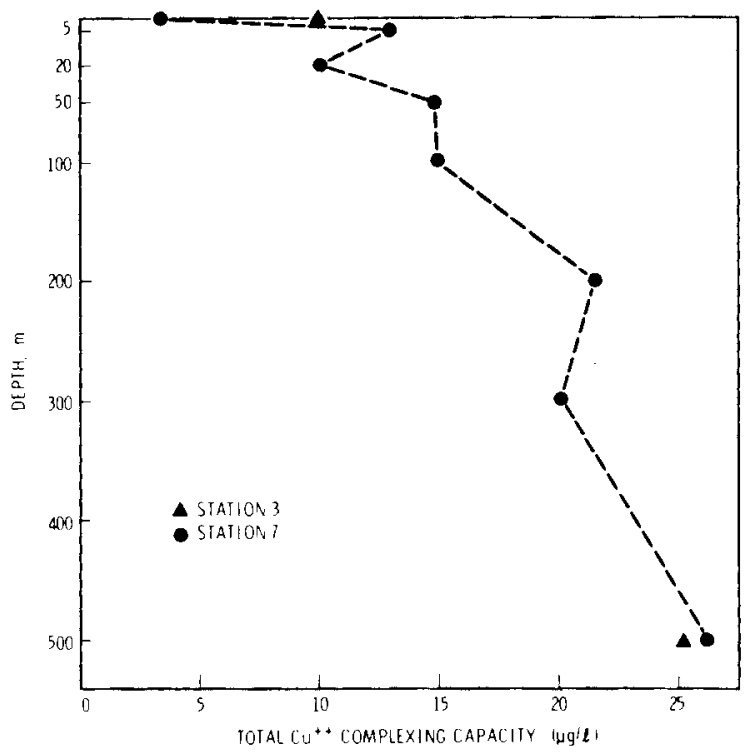

FIGURE 9.4. Complexing Capacity of Seawater Collected from Stations in Jervis Inlet, British Columbia During a Cruise Aboard the Canadian Research Vessel Vector, July 1977.

Research at this laboratory and ot'rers has indicated that the addition of an oxidant such as $\mathrm{Cl}_{2}$ or ozone increases the amount of ASV-measurable and therefore bioavailable metals in seawater. To determine if low levels of chlorination increased metal availability, four species were exposed to copper, chlorine, and copper plus chlorine-amended seawater for one month. The concentration of copper used was below the average complexing capacity of Sequim Bay water. There was no increase in ASV-measurable copper in the chlorinated tanks. However, one species, $M$. inquinata, had increased body burdens in the copper-plus-chlorine case. The other organisms, $P$. staminea, Pandalus danae, and Eudistylia vancouveri, had varied responses but no increase in body burdens.

As noted earlier, the availability of pollutants in the marine environment depends to a large degree on processes occurring in the underlying sediments. We are therefore investigating the influence of chemical, physical, and biological (primarily microbiological) processes associated with sediments and suspended matter which affect the availability of pollutants to marine organisms. Investigations to date have emphasized interactions between trace metals and sediment with suspended particles, with primary emphasis on copper.

Ratios of copper to titanium have been used to calculate the apparent mineral and nonmineral forms of copper in suspended particulates in Sequim Bay. Mineral-associated copper appears to vary seasonally with runoff and winter storm activity. Nonmineral copper appears to vary with the growth, decay, and deposition of phytoplankton.

From initial studies, copper and zinc concentrations in Sequim $B$ ay sediments appear to vary with changes in organic carbon content. Titanium, manganese, and nickel concentrations within the sediments, however, exhibit a fairly uniform distribution.

The distribution of copper has been examined in more detail by subjecting sediment samples to sequential extraction with reagents selective for different fractions of trace metals (Table 9.1). It is apparent from the sediments examined that at least 30\% of the copper was associated with the organic fraction. Effective dissolution of the amorphic metal oxides was dependent on the prior removal of organic matter, which suggests an indirect effect of the organic fraction on copper species not directly associated with organic components.

Preliminary field experiments show that soluble copper and organic carbon concentrations in sediment pore water exceed concentrations in overlying seawater by an order of magnitude. In addition, the electrochemical complexation capacity of the soluble organic matter in the pore water is two orders of magnitude greater.

Laboratory studies have shown that copper levels in sediments incubated with filtered seawater (1:9) decreased under anaerobic conditions. The decrease in copper levels apparently correlated with the population of sulfate-reducing bacteria. These results would suggest that, under the appropriate field conditions, soluble copper could be decreased by the growth of sulfate-reducing bacteria. The direct cause of this decrease may be attributed to the production of sulfide ion by these microorganisms.

In the coming year, we plan to verify the usefulness of the ASV for measuring "available" metal under a variety of conditions, address the questions raised about the availability of sediment-contained contaminants, and investigate furtiner the effects of chlorine, particulates and other 
TABLE 9.1. Distribution of Copper in Sequim Bay Sediments.

\begin{tabular}{|c|c|c|c|c|c|c|}
\hline \multirow[b]{2}{*}{ Fraction } & \multirow[b]{2}{*}{ Component } & \multirow[b]{2}{*}{ Extractant } & \multicolumn{2}{|c|}{ Station 1} & \multicolumn{2}{|c|}{ Station 4} \\
\hline & & & $\mu \mathrm{g} / \mathrm{g}$ & $\%$ & $\mu \mathrm{g} / \mathrm{g}$ & $\%$ \\
\hline 1 & $\begin{array}{l}\text { Weakly complexed, } \\
\text { easily soluble }\end{array}$ & $2.5 \%$ acetic acid & 1 & 2 & 1 & 3 \\
\hline 2 & Organically associated & $\begin{array}{l}0.1 \mathrm{M} \text { Na pyrophosphate } \\
5 \% \mathrm{Na} \text { hypochlorite }\end{array}$ & 15 & 30 & 6 & 22 \\
\hline 3 & $\begin{array}{l}\text { Associated with } \\
\text { amorphic metal oxides }\end{array}$ & $\begin{array}{l}1 \mathrm{M} \text { hydroxylamine hydro- } \\
\text { chloride in } 25 \% \text { acetic acid }\end{array}$ & 14 & 28 & 11 & 39 \\
\hline 4 & Residual & - & 20 & 40 & 10 & 36 \\
\hline
\end{tabular}

physical and chemical parameters on the availability of contaminants produced by energy. Laboratory studies will be continued to determine the flux and bioavailability of trace metals, particularly copper, in sediments under varied environmental conditions. In addition, studies are currently under way to tetermine the seasonal changes in the concentration of soluble trace metals and organic carbon in both sediment pore water and the overlying seawater. 


\section{- Marine Chemistry of Energy-Generated Pollutants}

\section{- In Situ Pollutants}

Principal Investigators: E. A. Crecelius, D. E. Robertson, K. H. Abel and N. A. Wogman

Other Investigators: C. L. Wilkerson, K. K. Nielson, L. A. Rancitelli, D. A. Cochran and C.W. Philbrick

This program is designed to increase our understanding of the biogeochemical and physical processes that control the fate of energy-generated pollutants that enter the marine environment. The increased energy needs of our country and increased utilization of the coastlines for siting energy-generating facilities and related industries have resulted in the introduction of energy-related pollutants to the oceans from two main sources: 1) the emission of large quantities of material to the atmosphere and subsequent deposition in the oceans, and 2) direct discharges to the oceans from coastal effluents.

The information generated by this program is vital to the U.S. DOE's interests in understanding 1) the natural origins, distributions and concentrations in baseline data of trace metals and other contaminants in the oceans; 2) the input rates and mixing rates of pollutants introduced to the oceans; 3) the behavior and fate of the anthropogenic pollutants entering the oceans from the atmosphere and the continents; and 4) an assessment of the potential environmental impact of energy-generated pollutants on the marine environment. Specific tasks that were accomplished during the last year include determining the solubility of airborne particulates in seawater, shipboard analysis of mercury in seawater by a new, more sensitive technique and analysis of trace elements in coastal and oceanic waters.

The In Situ Pollutants prograin provides feasibility evaluation, development, and application of instrumental technology for the in situ analysis of the wide spectrum of inorganic, organic and radionuclide species in ocean and freshwater sediments. of particular interest this year is sediment analysis by $X$-ray fluorescence.

The Solubility of Airborne Particulate Elements When Added to Seawater

The solubility of airborne particulate elements in seawater was determined for marine aerosol samples collected on the Washington coast. The samples used were representative of marine aerosol composition as opposed to continental aerosol. Sections of the dust-coated air filters were gently agitated in seawater for two leaching periods $(0.5$ and $6 \mathrm{hr})$, then filtered through a $0.1 \mu \mathrm{m}$ membrane filter and the fiitrate was analyzed. The soluble fraction did not increase between 0.5 and $6 \mathrm{hr}$. The elements were divided into the following classes, based on the percentage of the element on the air filter that dissolved 1) very soluble (>97\% soluble) sodium, bromine and cesium; 2) partly soluble $(20-80 \%)$ zinc, arsenic, selenium, cobalt, antimony and chromium; 3) slightly soluble (1-20\%) scandium, iron, cerium and europium and 4 ) insoluble $(<1 \%)$ lanthanum, hafnium, ytterbium, palladium, and lutetium (Table 9.2). The very soluble elements are believed to be associated with sea 
TABLE 9.2. Solubility of Marine Airborne Particulate Elements in Seawater.

\begin{tabular}{ccc} 
Element & \% Soluble \\
\cline { 3 - 3 } $\mathrm{Na}$ & 98 \\
$\mathrm{Br}$ & 97 \\
$\mathrm{Cs}$ & 100 \\
$\mathrm{As}$ & 49 \\
$\mathrm{Se}$ & 27 \\
$\mathrm{Sb}$ & 35 \\
$\mathrm{Zn}$ & 76 \\
$\mathrm{Co}$ & 51 \\
$\mathrm{Cr}$ & 23 \\
$\mathrm{Fe}$ & 8 \\
$\mathrm{Sc}$ & 5 \\
$\mathrm{Ce}$ & 10 \\
$\mathrm{Eu}$ & 14 \\
$\mathrm{La}$ & $<1$ \\
$\mathrm{Hf}$ & $<1$ \\
\hline
\end{tabular}

salt. The partly soluble elements could come from several sources including sea salt, anthropogenic aerosol and crustal material. The slightly soluble and insoluble materials are probably from crustal material. Studies are now under way to determine the chemical forms of some of the dissolved elements. Information on the chemical form is necessary to predict the bingeochemical behavior of the elements.

\section{Separation of Gallium, Selenium and Tellurium}

Marine geochemistries of gallium, selenium and tellurium are not presently well defined; the concentration of tellurium is not known in marine waters, and measurements of gallium and selenium are few, indicating concentrations of a few $\mathrm{ng} / \mathrm{l}$. These elements are semivolatile and thus may be enhanced in emission from high temperature anthropogenic activities such as fossil fuel combustion and metallurgy. Thus the potential exists for anthropogenic alteration of the geochemical cycling of these elements. If this is to be examined and understood, accurate measurements are necessary in the coastal waters.

We have developed a multi-step separation for these elements. The procedure utilizes coprecipitation from 25 l of filtered seawater with iron hydroxide at $\mathrm{pH} 5.1$ to 6.2. The seawater then is refiltered to remove the iron hydroxide using 0.4 Nuclepore ${ }^{\circledR i}$ fters and the precipitate is digested by hot U1trex sodium hydroxide. This digestion extracts the selenium, tellurium and gallium from the iron hydroxide phase and also dissolves the Nuclepore filter. The sodium hydroxide solution is then rendered acidic to $\mathrm{pH} 1$ with irl. This results in precipitation of the cellulose filter media tissolved during digestion. The cellulose is soparated by centrifugation, the supernate is then extracted with MIBK and diethyl ether for separation of the selenium, tellurium, and gallium, respectively.

The procedure is advantageous since the reagents used can io obtained in ultraclean condition or readily purified to the extent nerissary. Evaluation to date using radiochemical tracers $75 \mathrm{Se}, 72 \mathrm{ag}$, and $129 \mathrm{mTo}$ has indicated that each procedural step is $>30 \%$ efficient and overall efficiency is $35-90 \%$.

Thus far near-surface water samples have beon obtained aboard the research vessel Cayuse during the Jilly 1978 cruise. Samples were also collected from Alas'can coastal waters during August 1979. These samples are presently being analyzed.

\section{Mercury in Coastal Waters}

We have utilized a newly developed, highly sensitive procedure for mercury analysis of seawater to confirm our initial observations of extremely low concentrations of mercury in Oregon and Washington coastal waters. During a cruise of the research vessel Cayuse in Puget Sound and off the Washington coast, soluble mercury concentrations were measured on board. The analytical technique involves concentrating the mercury from $800 \mathrm{ml}$ of seawater by reducing and volatilizing the mercury and catching the vapor on a tube of gold-coated glass beads. The mercury is then heated off the beads and carried in a stream of nitrogen gas into a sensitive atomic absorption mercury analyzer. The sensitivity of the technique is about $0.1 \mathrm{ng}$ of mercury. Water collected near the mouth of the Columbia River contained $0.53 \mathrm{ng} / \mathrm{l}$ of mercury. Water samples collected of $f$ the Alaskan coast in Cook Inlet and analyzed at the same time onboard the Cayuse contained $2.0 \mathrm{ng} / \mathrm{l}$ of mercury.

Concentrations of mercury in Pacific Northwest seawater are shown in Table 9.3 . Water samples from the Was'nington coast were collected in Teflon-coated Niskin G-Flo hottles. Experiments were conducted to determine whether the sampling bottle either adsorbed or released mercury during seawater sampling. The storage experiments indicated that over a ?-hr period less than $10 \%$ of an ionic $203 \mathrm{Hg}$ spike was adsorbed. Also, contamination of seawater by mercury released irom the sampling bottle was less than $0.1 \mathrm{ng} / \mathrm{l}$ over a 2 -hr period. 
TABLE 9.3. Mercury Concentration in Pacific Northwest Seawater.

\begin{tabular}{|c|c|c|}
\hline \multicolumn{3}{|c|}{ Sample } \\
\hline Washington Coast & Station & Depth, m \\
\hline \multirow[t]{8}{*}{ July, 1978} & 6 & 10 \\
\hline & 13 & 10 \\
\hline & 14 & 10 \\
\hline & 18 & 10 \\
\hline & 18 & 200 \\
\hline & 19 & 10 \\
\hline & 19 & 200 \\
\hline & 19 & 400 \\
\hline
\end{tabular}

Sequim Bay Surface

April 19-26

July $10-13$

July 27

0.4

August 28

Elemental Characterization of the International Atomic Energy Agency Standard Fish Homogenate MA-A-2

Coastal zone studies requiring the measurement of trace elements in marine organisms are greatly benefited by the availability of reference materials which have both a suitable material matrix and well-documented elemental abundances. Such standard reference materials are extremely useful to the evaluation and quality assurance of analytical methods employed in the trace element characterization of marine samples. During the past year our laboratory participated in a multi-element characterization of the newly circulated reference material $\mathrm{F}$ ish Homogenato MA-A-2. This fish tissue material was developed and distributed by the International Atomic Energy Agency's Laboratory of Marine Radioactivity, Principality of Monaco, under a program of intercalibration in trace element analysis of marine environmental samples which was initiated in 1975.

In view of the inadequate comparability of measurements on trace elements in the marine environment on a national, regional or global basis, the Monaco Laboratory recognized the necessity of organizing an intercalibration exercise for such measurements on an international scale. The overall objective of the program is to serve countries and their marine science studies by supplying the means of analytical quality control for marine pollution monitoring and marine research in general. To implement

the program, the Monaco Laboratory has begun developing reforence materials from samples of marine organisms, marine sediments, and seawater.

In support of the objectives of this marine reference material program, our laboratory used instrumental neutron activation analysis (INAA) and $X$-ray fluorescence analysis (XRF) on two splits of the proposed reference material Fish Homogenate MA-A-2 for 53 major, minor and trace element constituents. Six or seven replicate analyses of each split were made by each of the two analytical techniques. The resulting data were corrected for a $4 \%$ water content and average elemental concentrations were then computed with Chauvenet's criteria applied to individual anoinalous values.

The results show that Fish Homogenate MA-A-2 is quite homogeneous for the majority of elements investigated and for samples as small as $0.1 \mathrm{~g}$. The few exceptions are silver, chromium, and titanium which were observed to vary significantly between samples, suggesting an inhomogeneity within the material matrix. A complete summary of the analyses is given in Table 9.7.

\section{In Situ Pollutants: Analysis of Sediments By X-Ray FTuorescence}

Modification of a prototype energydispersive X-ray fluorescence (XRF) analyzer for in situ analysis has been the focus of this program. While the device did analyze close to 30 elements of 20 to $50 \mathrm{ppm}$ in the top millimeter of sediment at water depths of $100 \mathrm{~m}$, it now analyzes elemental concentrations with sediment depth. The system has also been changed to allow its use on a minisubmersible, Link I, owned by the Harbor Branch Foundation. Several pollution studies were completed with the instrument using the mini-submersible in the Atlantic Ocean near $\mathrm{Ft}$. Pierce and West Palm Beach, Florida (Figure 9.5). In these studies, thorium, lead, arsenic, zirconium, and niobium were analyzed by laboratory study and in situ underocean XRF in standard matrix materials (Table 9.5A). The laboratory results were within $+25 \%$ of that determined by the underwater in situ analysis, except for thorium. This standardization qualified the accuracy of the in situ analyzer.

An area near the coast of North Palm Beach was subsequently analyzed for its pollutant concentration, the results of which are shown in Table 9.5B,C. Calcium, iron, zinc, lead, arsenic, zirconium and molybdenum were analyzed by in situ XRF and grab samples were analyzed by laboratory XRF. In general, the elemental concentrations compare well for calcium, iron, strontium, and zirconium using both laboratory and in situ techniques, 
TABLE 9.4. Summary of Elements Determined in IAEA Fish Homogenate MA-A-2 ( $\mathrm{gg} / \mathrm{g}$ dry weight).

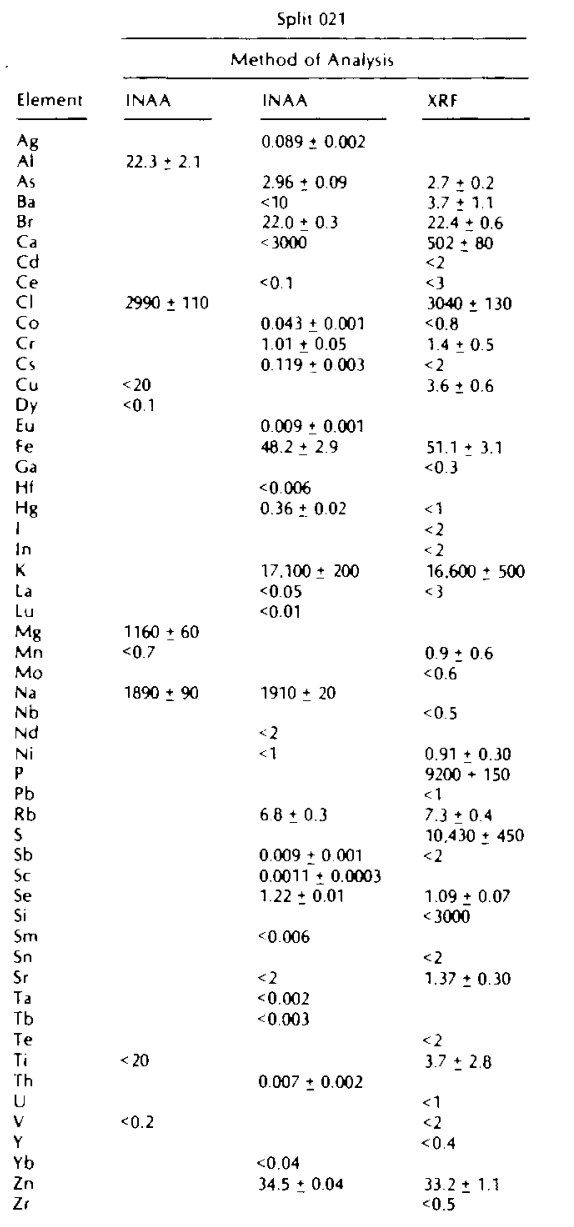

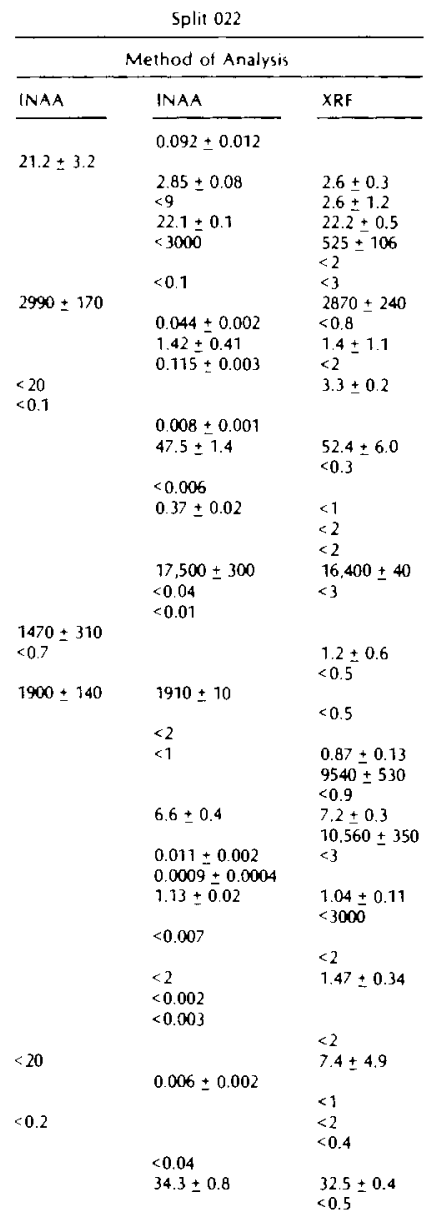

whereas the concentrations of arsenic, molybdenum, lead, and zinc do not agree. This nonagreement is similar to that found for these elements in polluted freshwater and ocean sediments in the state of Washington. The earlier data (Wogman and Nielson 1976), as confirmed by this series of measurements, suggested that bulk grab samples allow the measurement of elements distributed throughout the samples but are not representative of the material surface. The in situ technique analyzes elemental concentrations in the upper millimeter of surface. In these studies, the data developed by the in situ method, when compared to that from laboratory analysis, indicated that zinc, lead and arsenic have been removed by some mechanism to a greater sediment depth, while molybdenum was deposited on the sediment surface.

Table 9.5C, shows the concentrations of lead measured by the in situ technique and those obtained from grab samples analyzed by laboratory XRF. Five grab samples contained lead varying from 7 to $449 \mathrm{ppm}$. The concentrations of lead measured by the in situ instrument were less than 155 and $144 \mathrm{ppm}$ where the grab samples contained 449 and 237 ppm respectively. Of some 21 additional in situ measurements made of the lead concentrations, none showed any positive measurements of lead above $170 \mathrm{ppm}$. Areal concentration distributions were also obtained using the in situ instrument for calcium, titanium, vanadium, chromium, thorium, manganese, iron, cobalt, nickel, copper, zinc, mercury, selenium, arsenic, bromine, rubidium, uranium, strontium, ytterbium, zirconium, niobium, and molybdenum. These studies indicate that the underwater XRF method is viable for use with either submersible or a surface vessel. The method measures pollutant concentrations at levels normally encountered in the environment. The data also indicate that one can make these measurements in the same time as that normally required in the laboratory. The data also illustrate that the grab samples do not provide sediment surface pollutant element concentrations. The elemental concentrations of surface pollutant elements must be measured by the in situ technique. 


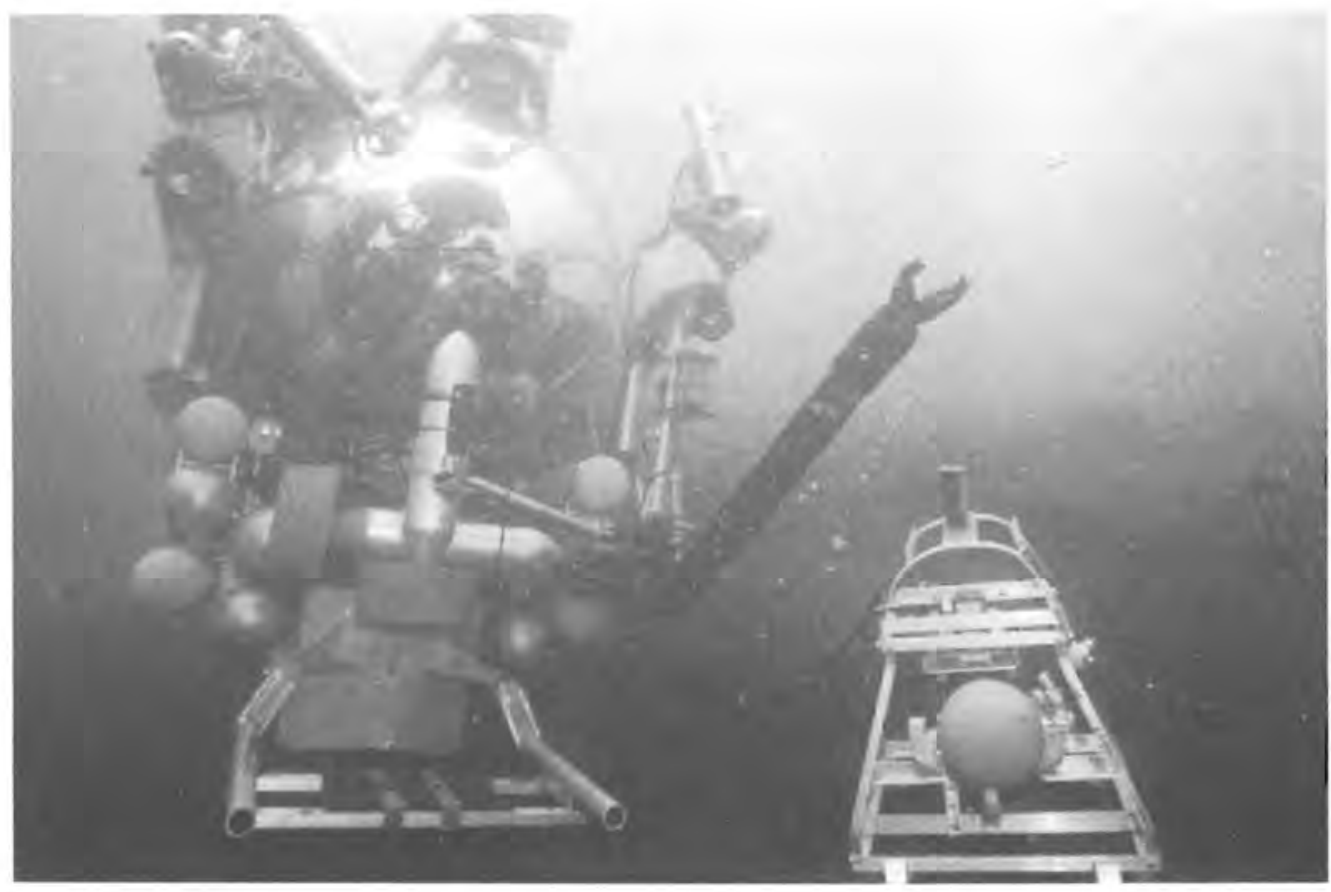

FIGURE 9.5. The Submersible, Link I, Placing the Battelle-Developed In Situ X-Ray Fluorescence Spectrometer on Sediments Below the West Palm Beach Sewage Outfall.

TABLE 9.5. A Comparison of In Situ and Laboratory X-Ray Fluorescence Analyzed Elemental Concentrations Obtained from Standards and Ocean Sediments (ppm).(a)

A. Standards(b)

\begin{tabular}{lcccc} 
Element & & $\begin{array}{c}\text { Laboratory } \\
\text { Analysis }\end{array}$ & & $\begin{array}{c}\text { In Situ } \\
\text { Analysis }\end{array}$ \\
\cline { 1 - 1 } Th & & 1000 & & 562 \\
$\mathrm{~Pb}$ & & $1.0 \%$ & & $1.0 \%$ \\
$\mathrm{As}$ & & 1000 & & 1200 \\
$\mathrm{Zr}$ & & $1.0 \%$ & & $0.82 \%$ \\
$\mathrm{Nb}$ & & 1000 & & 1260
\end{tabular}

B. North Palm Beach Outfall Ocean Sediments

\begin{tabular}{|c|c|c|}
\hline Element & $\begin{array}{c}\text { Laboratory } \\
\text { Analysis }\end{array}$ & $\begin{array}{l}\text { In Situ } \\
\text { Analysis }\end{array}$ \\
\hline $\mathrm{Ca}$ & $16.8 \%$ & $7.7 \%$ \\
\hline $\mathrm{Fe}$ & $1.7 \%$ & $1.6 \%$ \\
\hline $\mathrm{Zn}$ & 123 & $<467$ \\
\hline $\mathrm{Pb}$ & 449 & $<155$ \\
\hline As & 109 & $<130$ \\
\hline $\mathrm{Sr}$ & 471 & 530 \\
\hline $\mathrm{Zr}$ & 38 & 80 \\
\hline Mo & $<1$ & 20 \\
\hline
\end{tabular}

(a) Unless otherwise noted

(b) Prepared by mixing insoluble elemental compounds with dunite
C. North Palm Beach Outfall Lead

\begin{tabular}{|c|c|c|}
\hline $\begin{array}{c}\text { Laboratory } \\
\text { Analysis }\end{array}$ & $\begin{array}{l}\text { In Situ } \\
\text { Analysis }\end{array}$ & Comments \\
\hline 449 & $<155$ & In outfall plume \\
\hline 7 & & $100^{\prime}$ East of outfall \\
\hline 10 & & $100^{\prime}$ Northeast of outfall in plume \\
\hline 237 & $<144$ & $100^{\prime}$ Northeast of outfall in plume \\
\hline 52 & & 100 ' Southeast of outfall \\
\hline & $<170$ & $10^{\prime}$ East of outfail \\
\hline & $<\mathbf{1 5 6}$ & $16^{\prime}$ East of outfall \\
\hline & $<156$ & $20^{\prime}$ East of outfall \\
\hline & $<92$ & $15^{\prime}$ North of outfall in plume \\
\hline & $<111$ & $30^{\prime}$ North of outfall in plume \\
\hline & $<147$ & $50^{\prime}$ North of outfall in plume \\
\hline & $<167$ & $100^{\prime}$ North of outfall in plume \\
\hline & $<100$ & $125^{\prime}$ North of outfall in plume \\
\hline & $<168$ & $170^{\prime}$ North of outfall in plume \\
\hline & $<142$ & $200^{\prime}$ North of outfail in plume \\
\hline & $<151$ & $200^{\prime}$ North of outfail in plume \\
\hline & $<99$ & $300^{\prime}$ North of outfall in plume \\
\hline & $<99$ & $380^{\prime}$ North of outfall in plume \\
\hline & $<168$ & $475^{\prime}$ North of outfall in plume \\
\hline & $<133$ & $750^{\prime}$ South of outfall \\
\hline & $<136$ & $580^{\prime}$ South of outfall \\
\hline & $<125$ & $510^{\prime}$ South of outfall \\
\hline & $<148$ & $420^{\prime}$ South of outfail \\
\hline & $<90$ & $330^{\prime}$ South of outfall \\
\hline & $<96$ & $900^{\prime}$ Northeast of outfall in plume \\
\hline & $<136$ & $600^{\prime}$ Northeast of outfall in plume \\
\hline
\end{tabular}


$\gamma$ 


\title{
- DOE-Funded Oceanographic Cruises
}

\section{- Coordination of West Coast Marine Programs}

\author{
Principal Investigators: E. A. Crecelius
}

and W. L. Templeton

During FY 1978 two cruises were conducted in the offshore waters of Washington and Oregon. In addition to collecting air and seawater samples for laboratory analysis, shipboard analyses for mercury, total copper, and copper complexing capacity were conducted successfully. The coordinator of the West coast marine prograins, in addition to visiting selected principa? investigators on the West Coast, conducted a workshop on copper in the marine environment and an information meeting attended by all principal investigators and representatives of selected federal agencies.

\section{DOE-FUNDED OCEANOGRAPHIC CRUISES}

During FY 1978, Battelle-Northwest staff conducted two oceanographic cruises on the Oregon State University research vessel Cayuse. The cruises were funded by the Department of Energy, and data gathered on the cruises supported DOE Marine Science programs at the Marine Research Laboratory in Sequim and PNL in Richland.

The cruise in October 1977 began in Newport, Oregon and ended in Port Angeles, Washington. The purpose of the cruise was to study the processes that control the concentrations of energy-related pollutants in coastal seawater. Sampling was concentrated along several transects frequently sampled by other DOE-funded investigators from the University of Washington and Oregon State University. Battelle-Northwest staff have sampled twice before on these transects. Samples of water, suspended matter, chlorophyl1, salinity, airborne particulates and vapor mercury in air were collected. Shipboard seawater analysis of mercury, total copper and copper complexing capacity was very successful. Air particulate samples will be compared to samples collected simultaneously on the Washington coast at the Quillayute baseline air chemistry station. These data will be used to estimate atmospheric input of energy-related pollutants to the coastal area. Several stations were sampled in Puget Sound and the Seattle harbor.
All together, the locations of our stations range from an industrial harbor to the open ocean.

The July cruise extended from Port Angeles to Astoria. Washington State coastal waters, including the Straits of Juan de Fuca and the Pacific 0cean were sampled on transects extending from near shore to farther away than $80 \mathrm{~km}$. In addition to filtration and acidification of $1-\ell$ seawater samples for trace element analysis as conducted on previous cruises, shipboard mercury analyses were conducted. Also, at selected stations, $25-\ell$ samples were $f i 1$ tered into carboys for subsequent separation and analys is of selenium, tellurium, and gallium.

\section{COORDINATION OF WEST COAST MARINE PROGRAMS}

A workshop on copper in estuarine, continental and marine waters was organized in conjunction with the fall meeting of the American Geophysical Union in December 1977. The purpose of the workshop was to discuss the state of knowledge on the topic, evaluate present research, and to provide directions for future research. Over 50 participants attended, representing research supported by DOE and other federa? and state agencies, institutions, and universities. A report, DOE-CONF-771236, was published.

An information meeting of all the principal investigators supported by DOE on the 
West Coast was held at Scripps Institute of Oceanography in April. Representatives from National Oceanographic and Atmospheric Administration (NOAA), National Marine Fisheries Service (NMFS), Environmental Protection Agency (EPA) and Bureau of L-and Management (BLM) attended. Short presentations were made by each investigator.

The coordinator attended the DOE information meetings held for DOE-supported northeast Atlantic investigators at Brookhaven and for southeast Atlantic investigators in Atlanta, and program reviews held at Scripps Institute of Oceanography and the University of Washington. He visited the Mid-Pacific Marine Laboratory operated by the University of Hawai for DOE at Enewetak, Marshall Islanis. At a NOAA workshop defining national research needs under the National Ocean PolTution Research and Development and Monitoring Plan Act of 1978, the coordinator chaired a panel on artificial radionuclides in the oceans. 


\section{Literature Cited}

Eberhardt, L. L. 1977a. "Optimal" management policies for marine marmals. Wildlife Society Bulletin 5(4): 162-169.

Eberhardt, L. L. 1977b. Optimal policies for conservation of large mammals, with special reference to marine ecosystems. Environmental Conservation 4(3): 205-212.

Eberhardt, L. L. 1977c. Relationship between two stock-recruitment curves. Journal of the Fisheries Research Board of Canada 34(3): 425-428.

Eberhardt, L. L. 1978a. Appraising variability in population studies. Journal of Wildlife Management 42(2): $207-23 \overline{8}$.

Eberhardt, L. L. 1978b. Transect method for population studies. Journal of Wildi ife Management 42(1): 1-31.
Eberhardt, L. L., and Siniff, D. B. 1977. Population dynamics and marine mammal management policies. Journal of the Fisheries Research Board of Canada 34(2): 183-190.

Siniff, D. B., Eberhardt, L. L., DeMaster, D. D. and Hofman, R. J. 1977. An analys is of the dynamics of a Weddell seal

population. Ecological Monographs 47 :

319-335.

Siniff, D. B., Stirling, I. and Eberhardt, L. L. 1978. Problems in the conservation of polar marine mammals. In Polar research, to the present and future, ed. M. A. McWhinnie, pp. 161-173. AAAS Symposium, volume 7 .

Wogman, N. A. and Nielson, K. K. 1976. In situ parts-per-million analysis of marine sediments by $X-r a y$ fluorescence techniques, pp. 12A-1-12A-7. Oceans 76, MTS-IEEE Symposium. Washington: Marine Technology Society. 



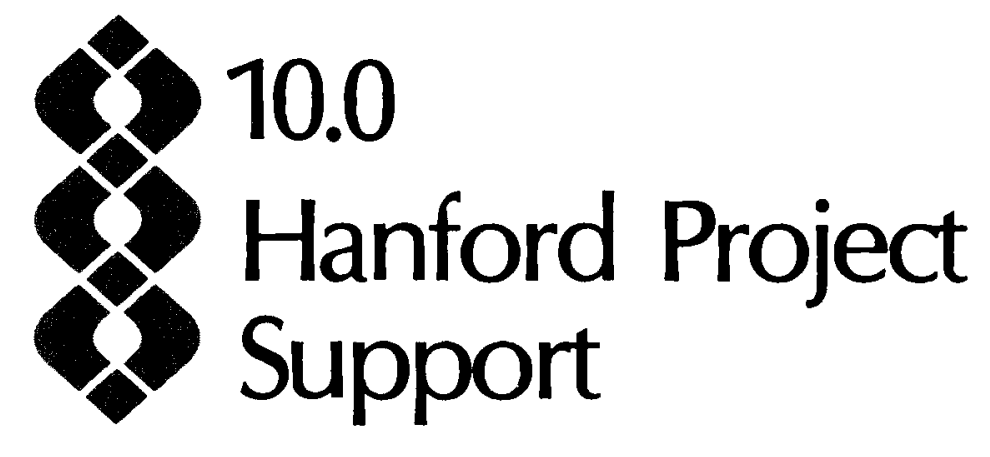




\section{HANFORD PROJECT SUPPORT}

\section{- Rockwell Support (200 Area Burial Ground) Studies}

- Decommissioning and Decontamination (300 Area Burial Ground) Studies

\section{- Service Assessment Studies}

This section reports on related environmental studies organized either in support of the Rockwell Hanford Operations' waste management responsibilities or as part of the Decommissioning and Decontamination program under direct DOE funding.

These studies are designed to 1) ascertain the potential for uptake and transport of waste radionuclides away from shallow low-level waste burial grounds located on the Hanford Site, 2) to develop techniques for guarding burial grounds against biotic penetration and 3) to monitor over long intervals the several most important animals likely to be impacted by industrial development of the Hanford Site. 



\title{
- Rockwell Support Studies
}

\author{
Principal Investigators: L. E. Rogers \\ and L. L. Cadwell \\ Other Investigators: D. A. Cataldo, \\ K. A. Gano, R. E. Fitzner, R. E. Wildung, \\ J. F. Cline and D. W. Uresk
}

Technical Assistance: M. A. Combs, L. F. Nelson, C. A. Lee, M. J. Harris, V. D. Charles and

H. A. Sweany

Studies performed for the Rockwell Hanford Operations were designed to either 1) clarify the role of specific biota in the uptake and transport of radionuclides from shallow, low-level waste burial sites or 2) evaluate the radioactive exposure levels to biota inhabiting such sites. Tasks include studies on burrowing animals and shrub-inhabiting insects, dose distribution evaluation, environmental assessment of raptors, study of radionuclide levels in blacktailed hares, field plant uptake studies, plant uptake (laboratory) studies and burial ground stabilization studies.

\section{Burrowing Animal Studies - Ants}

This task was designed to evaluate the potential for burrowing animals transporting buried wastes to the ground surface. Initial efforts focused on ants. Surveys of ground squirrel colonies and coyote and badger burrowing sites are planned for later study.

A review of the literature reveals a paucity of information concerning the nest structure and tunneling habits of most ant species known to inhabit the Hanford Site, except harvester ants (Pogonomymex spp.). P. californicus has been found to tunnel to $\bar{a}$ depth of $2 \mathrm{~m}, \mathrm{P}$. Owyhee $\mathrm{p}$ to $2.4 \mathrm{~m}$ and $P$. occidentalis to $3 \mathrm{~m}$. This shows a range of maximum tunneling depths from 2 to $3 \mathrm{~m}$ which compares favorably with tunnel depths ranging from 1.7 to $2.7 \mathrm{~m}$ measured for colonies occupying the 200 West Plateau.

The total amount of soil excavated over the life of a colony can be calculated by summarizing the volume of soil movement required during construction of tunnels and chambers associated with excavated nests. Excavations of five colonies from the 200
Area Plateau revealed an average of $1774 \pm 453$ (SE) $\mathrm{cm}^{3}$ of soil excavated per colony.

A recent study within 300 Area burial grounds revealed an average density of 32 colonies per hectare. Extrapolating colony density estimates ( 32 colonies/ha) with soil volume excavation estimates (1774 cm /colony) permits expression in terms of total soil volume excavated by harvester ants $(56,768$ $\mathrm{cm} 3 / \mathrm{ha}$ of soil). Assuming a soil bulk density of $1.2 \mathrm{~g} / \mathrm{cm}$ permits expression in terms of the mass of soil excavated. This is estimated at $68.1 \mathrm{~kg}$ of soil moved to the surface per hectare of waste burial ground. This assumes that colony densities for 300 Area burial grounds are equivalent with those for 200 Area burial grounds, which has not been verified. About $11 \%$ of the nest volume was found to occur at depths greater than $1.5 \mathrm{~m}$ for the 200 Area harvester ants. This means that harvester ants occupying 200 Area shallow waste burial sites could move about $7 \mathrm{~kg}$ of soil material to the surface per ha from this depth. Clearly harvester ants possess the potential for moving small particles of contaminated material to the surface of 200 Area shallow waste burial grounds. 
Shrub-Inhabiting Insects

This study characterizes the insects associated with the major shrubs of the 200 Area plateau. Big sagebrush (Artemisis tridentata), rabbitbrush (Chrysothamnus nauseosus) and hopsage (Grayia spinosa) were the three shrubs included in the study.

The seasonal distribution of insect abundance on big sagebrush is shown in Figure 10.1A. Peak abundance occurred earlier in 1974 than the time span appearing in the diagram. The abundance values followed similar patterns in all three study areas, peaking in April or May of both study years. Insect abundance associated with rabbitbrush and hopsage is shown in Figure 10.1B. The seasonal pattern for insect abundance on rabbitbrush appears bimodal, peaking in May or June and again during September and 0ctober. The June peak was comprised mostly of Homoptera (bugs) and Orthoptera (grasshoppers), but the October peak appeared to consist of several different taxa. There were no clear patterns of insect abundance on hopsage.
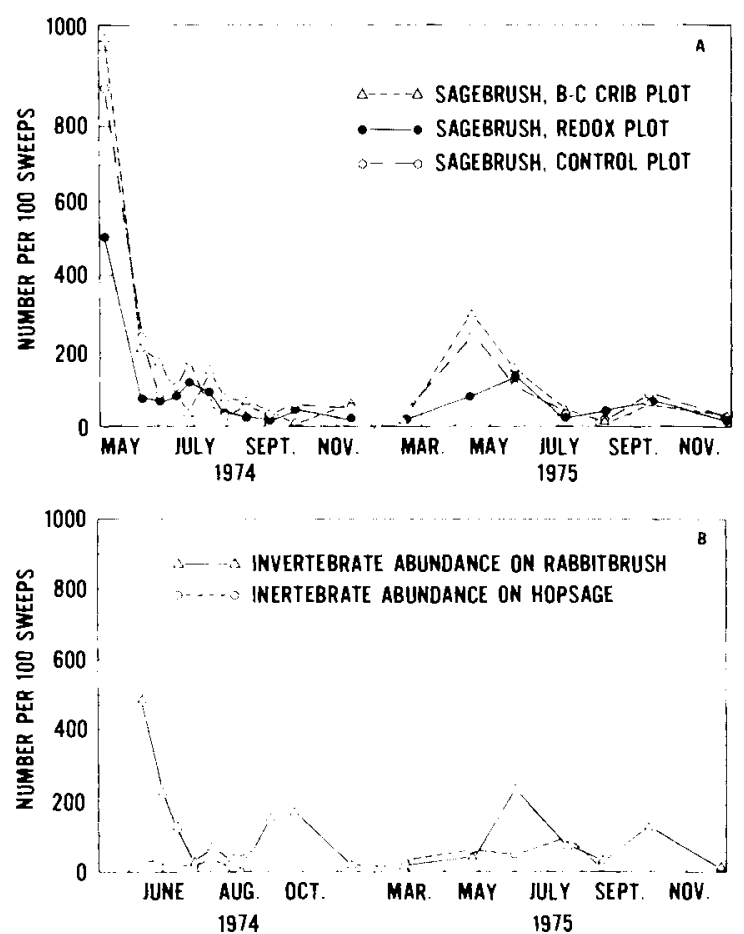

FIGURE 10.1. Comparison of Seasonal Distribution of Insect Abundance on Sagebrush, Hopsage and Rabbitbrush. Insects were collected with a standard sweep net.
Hemiptera (true bugs) and homoptera (bugs) were the two groups most abundant on sagebrush. Homoptera and Araneida (spiders) were the common inhabitants of rabbitbrush, and Orthoptera (grasshoppers), Coleoptera (beet les) and Araneida the taxa most frequently collected from hopsage. None of the insect populations appear presently threatening to shrub stands on the 200 Area plateau.

Dose Distribution Evaluation

This task was intended to evaluate the exposure dose received by various biota inhabiting the 200 Area plateau. Thermoluminescent dosimeters were placed on wild ducks, beetles and bird nests. The $137 \mathrm{Cs}$ content of soil excavated by harvester ants (Pogonomyrmex owyheei) occupying the A-24 Crib was also analyzed as part of this task and is described here.

Gamma Exposure in Magpie Nests Measured by Thermoluminescent Dosimeters

This study measured gamma exposure in magpie nests at different locations on the Hanford Site. Twelve nests were selected from radiation zones in the 200 West Area, from an uncontaminated area near 200 East and from an area near the Columbia River, which was far from any radiation zone. For each nest, dosimeters mounted on dowels measured the exposures inside and outside the nest.

of the 12 nests measured, eight yielded dosimeter returns. The dosimeters and dowels in the remaining four nests were not found. Results showed the highest exposure rate in nests located near U-Pond, a low-level radioactive waste pond (Table 10.1). These exposure rates ranged from 54 to $71.5 \mathrm{mR} /$ week. Nests in uncontaminated areas ranged from 0.53 to $1.4 \mathrm{mR} /$ week.

This technique was not entirely successful because in most cases the dowels had fallen out of the nest by the time they were recovered. However, the values for the dosimeters that were found remaining in the nests

(nest \#1 and \#7) were very close to those in the same group that had fallen to the ground.

Gamma Exposure to Darkling Beetles on the A-24 Crib

The purpose of this study was to evaluate garma exposure received by darkling beetles (Philolithus densicolis) inhabiting the 200 Area plateau.

Dosimeters were sealed in plastic packets of two each and fixed to the elytra of darkling beetles, which were then released on the A-24 Crib. Additional dosimeter-carrying beetles were placed on an existing pitfall 
TABLE 10.1. Gamma Exposure in Magpie Nests.

\begin{tabular}{|c|c|c|}
\hline Nest No. and Location & $\mathrm{mR} /$ week & $\mathrm{mR} /$ year \\
\hline \multicolumn{3}{|c|}{ SE Corner of 200 East Area } \\
\hline 1 & 1.39 & 72.2 \\
\hline $2^{(a)}$ & 1.09 & 57.0 \\
\hline $3^{(a)}$ & 0.80 & 41.8 \\
\hline \multicolumn{3}{|l|}{ East Side of U-Pond } \\
\hline 7-1 Inside Nest & 62.6 & 3266 \\
\hline 7-2 Outside Nest & 56.2 & 2932 \\
\hline \multicolumn{3}{|l|}{ South Side of U-Pond } \\
\hline 8-1 Inside Nest (a) & 54.0 & 2816 \\
\hline 8-2 Outside Nest & 71.5 & 3727 \\
\hline \multicolumn{3}{|l|}{ Hanford Townsite } \\
\hline $10(\mathrm{~b})$ & 0.68 & 35.7 \\
\hline 11-1 Inside Nest & 0.53 & 27.8 \\
\hline 11-2 Outside Nest & 0.61 & 31.7 \\
\hline 12-1 Inside Nest (a) & 0.53 & 27.8 \\
\hline 12-2 Outside Nest & 0.68 & 35.7 \\
\hline
\end{tabular}

(a) Dosimeters were found on the ground.

(b) One dosimeter packet was found on the ground.

trap-grid located near Rattlesnake Springs as controls. Dosimeter packets were also attached to sagebrush in the same area to be used as backups in case the control beetles were not recovered. The total exposure time for all dosimeters was nine days.

Results from dosimeters recovered on the control plot showed a mean background exposure of $1.6 \mathrm{mR} /$ week. The dosimeters carried by beetles on the A-24 Crib revealed exposures ranging from $5.4 \mathrm{mR} /$ week to $242 \mathrm{mR} /$ week with an average of $102 \mathrm{mR} /$ week (Table 10.2). The controls that were recovered from beetles and shrubs had very similar exposures.

Gamma Exposure Rates to Wild Mallard Ducks on a Low-Level Radioactive Waste Pond

The mallard duck (Anas platyrhynchos) is a common nesting species an the low-level
TABLE 10.2. Gamma Exposure to Darkling Beetles on A-24 Crib.

\begin{tabular}{lcccc} 
& \multicolumn{3}{c}{$\mathrm{mR} /$ week } \\
\cline { 2 - 3 } & $\mathrm{n}$ & $\overline{\mathrm{X}} \mathrm{SE}$ & & Range \\
A-24 Crib & 50 & $101.7 \pm 9.0$ & & $5.4-241.9$ \\
Beetle Controls & 8 & $1.6 \pm 0.08$ & $1.3-2.0$ \\
Bush Controls & 18 & $1.2 \pm 0.07$ & $0.7-1.7$ \\
\hline
\end{tabular}

radioactive waste ponds on the Hanford Site. Its use of the ponds permits exposure to ionizing radiation from radioactive waste deposited in pond sediments and from contaminated food. Externally attached dosimeters were used to determine the gamma exposure rates, if any, received by mallards utilizing U-Pond. Two dosimeter packets containing three LiF dosimeters were sewn to the bases of the primary feather shafts of each of ten wing-clipped, wild mallards. These ducks were released on U-Pond in February, 1978 and recaptured several weeks later. Table 10.3 provides data on exposure rates for the five ducks which were recaptured.

In order to determine if the exposure rate recorded at U-Pond was different from that at a noncontaminated pond, another experiment was conducted. Dosimeter packets were attached to blocks of wood and were floated on U-Pond and a control pond at the McNary National Wildlife Refuge. Blocks were left on the ponds for 31 days. Exposure rates for dosimeters on the control pond ranged from $0.016 \mathrm{mR} /$ week to $0.49 \mathrm{mR} /$ week. Exposure rates for dosimeters on U-Pond blocks ranged from $7.34 \mathrm{mR} /$ week to $12.2 \mathrm{mR} /$ week. Clearly $\mathrm{U}$-Pond exposure rates at the water surface were higher than those recorded for the control pond. We presently do not know what ecological significance this exposure has for waterfow 7 utilizing U-Pond.

TABLE 10.3. Gamma Exposure Levels for Mallards Inhabiting U-Pond, 1978.

\begin{tabular}{|c|c|c|c|c|c|c|c|}
\hline $\begin{array}{l}\text { Duck } \\
\text { ID No. }\end{array}$ & Sex & $\begin{array}{c}\text { Date } \\
\text { Released }\end{array}$ & $\begin{array}{c}\text { Date } \\
\text { Recaptured }\end{array}$ & $\begin{array}{l}\mathrm{mR} \text { Total } \\
\text { Exposure }\end{array}$ & $\mathrm{mR} /$ day & $\mathrm{mR} /$ week & $\mathrm{mR} /$ year \\
\hline 1 & $q$ & Feb 17 & Mar 17 & 90 & 3.21 & 22.5 & 1173 \\
\hline 2 & $\sigma^{x}$ & Feb 17 & Apr 4 & 133 & 2.89 & 20.2 & 1055 \\
\hline 3 & $q$ & Feb 17 & Apr 4 & 147 & 3.20 & 22.4 & 1166 \\
\hline 4 & $\hat{q}$ & Feb 17 & Apr 4 & 141 & 3.06 & 21.4 & 1118 \\
\hline 5 & $0^{x}$ & Feb 17 & Apr 28 & 180 & 2.58 & 18.3 & 940 \\
\hline
\end{tabular}


Cesium-137 Content of Ant Mounds on A-24 crib

The harvester ant is a common inhabitant of disturbed soils on the Hanford Site. Radioactive waste burial sites generaliy contain drastically disturbed soil, which makes them favorable sites for harvester ant colonies.

Soil from the surface of nine ant mounds on A-24 Crib was collected in early April 1978 when ants had recently begun their tunneling activities. In addition to the samples taken on the crib, six samples were taken from colonies located between $\mathrm{A}-24 \mathrm{Crib}$ and an adjacent crib. Four control colonies were also sampled in an area remote from any contaminated soils.

The samples were counted for ${ }^{137} \mathrm{Cs}$ in an ARMAC liquid scintillation detector. The highest concentration of $137 \mathrm{Cs}$ from a colony on the crib was $28.6 \mathrm{pCi} / \mathrm{gm}$. The other eight samples from the crib had much lower concentrations with an average of $2.63 \mathrm{pC} i$ $137 \mathrm{Cs} / \mathrm{gm} \pm 0.85 \mathrm{SD}$. The samples taken between cribs averaged $3.4 \mathrm{pCi} 137 \mathrm{Cs} / \mathrm{gm} \pm$ 1.21 SD. Concentrations in the control samples were slightly lower and averaged $0.84 \mathrm{pCi} 137 \mathrm{Cs} / \mathrm{gm} \pm 0.18 \mathrm{SD}$.

\section{Environmental Assessment of Raptors}

Birds of prey, as end-of-food-chain organisms, serve as useful barometers of environmental pollution in lower trophic levels. Contaminants in their tissues, especially heavy metals and pesticides, are of ten several orders of magnitude higher than in tissues of their prey.

In 1976 a study was begun to examine levels of radionuclides in the castings of raptors residing on and off the Hanford Site. Castings (regurgitated undigestable remains of prey) should provide a measure of radionuclides in prey species and may prove to be a valuable tool in long-term ecological monitoring of the environment. Analysis of castings also has the advantage of being a nondestructive technique; i.e., it does not require killing the birds of prey.

To date, the castings of two species of hawks (red-tailed, Swainson's) and three ow 1 species (great horned, long-eared, barn) have been examined. The only castings having ${ }^{137} \mathrm{Cs}$ leveis above those from offsite control locations were the 100-D Area barn ow samples (5.9 $\mathrm{pCi} / \mathrm{g})$ and one Swainson's hawk sample from the 200 East Area $(9.1 \mathrm{pCi} / \mathrm{g})$. Since hawks and owls often have wel1-def ined home ranges, the next step in our research should be radiotelemetry determination of home range areas. By coupling home range data with food habits and the radionuclide concentrations in castings, we should be able to better determine the specific places where radioactive contamination is entering the food web.

Radionuclide Levels in Black-Tailed Hares

Black-tailed hares (Lepus californicus) have been involved in the Tocalized spread of radioactive waste originating from the $B-C$ Cribs waste burial ground. Radioactive salts (presumed to have been exposed to the surface by a badger's digging) consumed by the hares were incorporated in body tissues and excreta. Once the problem was noticed, waste management operations covered the exposed salts and sealed the source from animals. Today the radioactivity deposited in fecal material is still present in the B-C cribs area. As the fecal matter decomposes and becomes incorporated into the soil, it has the potential to be incorporated into plant tissues. Hares eating these plants can become vectors of the radioactivity they ingest.

In order to determine if black-tailed hares living in the $B-C$ Cribs area have been ingesting and incorporating radioactivity into their bodies, systematic collections of animals near $B-C$ Cribs and at a control area near Boardman, Oregon were made. Collections began in December of 1977 and were made quarterly thereafter for one vear. At least four hares were collected from each study site during each survey. To date samples collected during the first two sampling periods have been analyzed for gamma-emitting radionuclides. Muscle, bone, and liver tissues have been examined. Table 10.4 provides the results for $137 \mathrm{Cs}, 40 \mathrm{~K}$ and $60 \mathrm{Co}$. These longlived gamma emitters were found on the same general order of magnitude for both study areas. Cesium- 137 levels in hares collected from the B-C Cribs area in March do indicate that even though $137 \mathrm{Cs}$ levels are low, they are higher than those found in Boardman hares collected at both study sites in December of 1977. These higher 137Cs values may indicate that hares living in the B-C Cribs area are ingesting some contamination which cannot be attributed to world-wide fallout. Samples of hares collected in June and September of 1978 will provide additional information which should enable us to determine if hares inhabiting B-C Cribs do in fact contain greater concentrations of radioactivity than hares in the control area. 
TABIE 10.4. Radionuclides in Black-Tailed Hare Muscle Collected from the Hanford Site (B-C Crib Area) and the Boardman, Oregon Area.

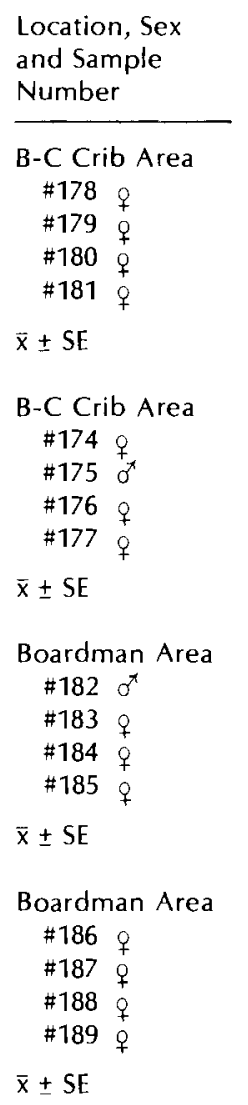

\section{Plant Uptake (Field) Studies}

The burial of long-lived fission products contained in radioactive wastes resulting from past and present reactor operations necessitate the understanding of the effect of long-term exposure of these elements to the environment. Of special concern is the effect of aging on the uptake of $90 \mathrm{sr}$ by plants.

This report compares the uptake by barley plants of $90 \mathrm{Sr}$ that was placed on field soil in 1954 with uptake of 85Sr added in 1957 and again in 1978. CR comparisons have been made between the $85 \mathrm{Sr}$ added in 1957 and again in 1978 and the aged $90 \mathrm{Sr}$. There was no difference in CR values at the $99 \%$ level between the two aged isotopes (applied in 1954 and 1957). However, the aged $90 \mathrm{Sr}$ CR value determined in 1978 (2.1) was significantly higher at the $95 \%$ level than the $C R$ value (1.8) for newly added $85 \mathrm{Sr}$. Studies are continuing to better characterize the apparent increase in plant availability of environmental strontium with time.
Radionuclides in Dpm/g

\begin{tabular}{|c|c|c|}
\hline${ }^{137} \mathrm{Cs}$ & ${ }^{40 K} \mathrm{~K}$ & ${ }^{60} \mathrm{Co}$ \\
\hline 0.26 & 39.0 & 0.13 \\
\hline 0.40 & 15.0 & 0.23 \\
\hline 0.68 & 7.1 & 0.30 \\
\hline 0.73 & 18.0 & 0.19 \\
\hline $52 \pm 0.11$ & $20 \pm 6.9$ & $0.21 \pm 0.03$ \\
\hline
\end{tabular}

\begin{tabular}{|c|c|}
\hline 1.1 & 21.0 \\
\hline 1.5 & 19.0 \\
\hline 1.6 & 20.0 \\
\hline 5.0 & 24.0 \\
\hline $2.3 \pm 0.84$ & $21 \pm 1.0$ \\
\hline
\end{tabular}

\begin{tabular}{c}
0.64 \\
0.24 \\
0.38 \\
0.44 \\
\hline $0.43 \pm 0.08$
\end{tabular}

\begin{tabular}{|c|c|c|}
\hline 0.53 & 23.0 & 1.2 \\
\hline 0.21 & 22.0 & 0.65 \\
\hline 0.16 & 18.0 & 0.16 \\
\hline 0.18 & 23.0 & 0.27 \\
\hline $27 \pm 0.08$ & $22 \pm 1.2$ & $0.58 \pm 0.25$ \\
\hline
\end{tabular}

\begin{tabular}{ccc}
0.61 & 20.0 & 0.37 \\
0.29 & 16.0 & 0.31 \\
0.73 & 16.0 & 0.24 \\
0.45 & 17.0 & \\
\cline { 1 - 1 } $0.52 \pm 0.09$ & $17 \pm 0.94$ & $0.29 \pm 0.03$
\end{tabular}

\section{Plant Uptake (Laboratory) Studies}

Cheatgrass (Bromus tectorum) and Russian thistle (Salsola kali) were used to determine the relative unavailability of radionuclides amended to Hanford area soils. Several studies were undertaken, including 1) evaluation of the relationships between properties of Hanford area soils and the availability of cesium and strontium for uptake by plants, 2) the comparative availability of cesium and strontium for plant absorption from Rupert surface soil and an associated subsoil as influenced by growth conditions and soil aging and 3 ) analysis of the behavior of technetium and $\mathrm{I}^{-}$in surface soils and subsoils, and their availabililty to plants following soil aging.

The relationships between plant root absorption mechanisms and basic soil parameters which effect the concentration of strontium, cesium and analog ions in soil solution were reviewed. Based on these relationships, studies were undertaken to determine the feasibility of developing a 
predictive relationship between plant availability of cesium and strontium, and readily measurable soil parameters. Concentration ratios (CR) were determined for cheatgrass and Russian thistle grown on Hanford area soils (Burbank, Ritzville, Lickskillet, Rupert and Warden) representing a range in properties. Concentration ratios ranged from 0.0078 to 0.066 for $134 \mathrm{Cs}$ and 3.5 to 16 for $85 \mathrm{Sr}$. Soils were analyzed for physical properties, mineralogy, extractable cations and extractable $134 \mathrm{Cs}$ and $85 \mathrm{5r}$. Simple correlation analyses showed cesium and strontium uptake in cheatgrass and strontium uptake by Russian thistle to be related to cation exchange capacity and extractable strontium, barium and magnesium. Uptake of cesium by Russian thistle showed weak correlations with extractable and exchangeable potassium. Factor analysis and principle components analysis did not assist in further quantitation of the relationships between plant uptake and soil parameters.

Studies were also undertaken to determine the comparative plant availability of $134 \mathrm{Cs}$ and $85 \mathrm{Sr}$ amended to Rupert suface soil and an associated subsoil. Concentration ratios for cheatgrass and tumbleweed grown on Rupert soil amended with $134 \mathrm{Cs}$ were 0.15 and 0.28 respectively; values for amended subsoils were 0.074 and 0.13 respectively. Rupert surface soil and subsoil amended with $85 \mathrm{sr}$ gave CR's of 15 and 7 respectively for both Russian thistle and cheatgrass. While pot size ( 1 vs $4 \mathrm{~kg}$ ) had a marked effect on CR, values for plants grown in a green house and in a growth chamber were generally similar. Aging of both Rupert surface soil and subsoils for 1 to 30 days prior to planting had a pronounced effect on the availability of $134 \mathrm{Cs}$ for uptake by plants, but no effect on 85 sr uptake.

The comparative availability to plants of ${ }^{99} \mathrm{TCO}_{4}^{-}$and $125 \mathrm{I}^{-}$amended to Rupert soil and an associated subsoil was determined for soils aged for periods of $1,10,30$ and 100 days prior to planting. Concentration ratios for cheatgrass grown on Rupert soil and subsoil amended with $99 \mathrm{TCO}_{4}^{-}$ranged from 185 to 91 an 466 to 309 respectively; values for
Russian thistle grown on Rupert soil and subsoil ranged from 148 to 82 and 881 to 173 respectively. Concentration ratios for both cheatgrass and Russian thistle grown on Rupert soil amended with 125 - ranged from 0.95 to 0.25 ; values for cheatgrass and Russian thistle grown on subsoil ranged from 3.5 and 1.3 and 13 to 5.8 , respectively. Analyses of $C R$, shoot concentrations and percentage of spike absorbed indicate a reduction in plant availability of both ${ }^{99} \mathrm{Tc}$ and 125I over the 100-day soil-aging period. This may result from insolubilization of ${ }^{99} \mathrm{TCO}_{4}^{-}$and anion exchange reactions for $125 \mathrm{I}^{-}$.

\section{Burial Ground Stabilization}

In this task, physical and/or chemical barriers were tested for their ability to block plant roots from penetrating into buried waste (simulated by lithium chloride). Six treatments were each tested four times; these were cobble, asphalt, cement, Urea-bor (a root toxin), Urea-bor plus asphalt and control (no treatment). Cheatgrass (Bromus tectorum) and Russian thistle (Salsola kali) were used as test plants. Root penetration was measured by analysis for lithium chloride in aboveground plant tissues.

In 1977, a dry year, Russian thistle dominated the test plot. Of the four replications of the control (no barrier), all showed evidence of root penetration to the lithium chloride. The cobble and cement layers were each penetrated in one instance, and the asphalt in three instances. Neither Urea-bor nor Urea-bor with asphalt were penetrated. In 1978, however, more precipitation fell and cheatgrass rather than Russian thistle dominated the plot. No root penetration to the lithium chloride was found in any treatment.

Conclusions drawn from this experiment are that 1) the only barriers to resist Russian thistle penetration were those containing the root toxin and 2) Russian thistle appears to prosper in dry weather when competition from other plant species is reduced. These data indicate that biological manipulations (species composition) might be a useful way to prevent root uptake of shallow buried wastes. 


\title{
- Decommissioning and Decontamination (300 Area Burial Ground) Studies
}

\author{
Principal Investigator: R. E. Fitzner \\ Other Investigators: J. F. Cline, K. A. Gano, W. H. Rickard and L. E. Rogers \\ Technical Assistance: H. A. Sweany, V. D. Charles and M. A. Combs
}

The decommissioning and decontamination of retired Hanford facilities and the future use of surrounding landscapes requires a comprehensive understanding of how components of the natural ecosystem interact with managed facilities. Ecological studies were developed to characterize the 300 Area waste burial grounds and to determine the potential for biotic transport of buried contaminated wastes away from managed facilities.

The 300 Area burial grounds are located in the bitterbrush-cheatgrass (Purshia tridentata-Bromus tectorum) vegetation community which occupies about 193,000 ha in the southeastern part of the Hanford Site. Undisturbed vegetation is dominated by desert shrubs, bitterbrush and sagebrush (Artemisia tridentata), usually in mixtures of about equal abundance. The understory to the shrubs is dominated by cheatgrass, an annual grass that reseeds itself each year. Seeds usually germinate in the fall with the onset of autumn rain and the plants reach maturity in early May. Standing dead cheatgrass provides ground cover throughout the summer months and helps to prevent erosion by wind.

Bitterbrush-cheatgrass vegetation is susceptible to fire; in 1961 and 1970 fires burned over an estimated 42,000 ha. Burning kills the shrubs. Cheatgrass re-invades the burned area from seeds that survive burning and from seeds blown or carried in from nearby unburned areas. Burned areas are usually also invaded by Russian thistle (Salsola kali). Russian thistle can dominate the vegetation for several years until cheatgrass re-establishes dominance, at which time Russian thistle persists in lesser abundance. Shrubs are slow to re-invade the burned areas.

Waste burial also destroys the existing vegetation. Russian thistle and cheatgrass are the early self-invaders of backfill, and the backfill of 300 Area burial grounds is usually occupied by a sparse cover of cheatgrass and Russian thistle. Shrubs are generally slow to establish themselves in backfill.
There are usually more birds, mammals, insects, and reptiles in shrub habitats than in communities of cheatgrass and Russian thistle alone. Backfill occupied by sparse stands of cheatgrass and Russian thistle, however, is inhabited by pocket mice, deer mice, black-tailed hares, horned larks, meadow larks, lizards and many kinds of insects, including the harvester ant.

One of the aims of waste burial is to isolate radioactive material from $\mathrm{plant}$ roots because plants have the ability to take up radionuclides incorporated into soil. Shrubs generally have deeper penetrating root systems than herbaceous species. Perennial herbs have deeper roots than annual herbs. To discourage the establishment of plants that can take up radionuclides, shallowrooted annual plants are the most desirable species on 300 Area burial grounds. Cheatgrass and Russian thistle are both annuals but Russian thistle has a deeper root system than cheatgrass. Russian thistle also has a greater affinity than cheatgrass for incorporating radionuclides into its tissues, as indicated by laboratory studies. Russian thistle also has the disadvantage of breaking off at ground level when mature, and the entire plant can be blown from burial grounds. Sometimes Russian thistles move several miles and may be carried off the Hanford Site.

Features desirable in plants growing on burial grounds, therefore, are 1) a shallow $(<1.8 \mathrm{~m})$ root system, 2) low radionuclide uptake from soil, 3) low potential for wind transport of tissues and 4) retardation of soil erosion. Cheatgrass has all four. 
Russian thistle meets only the fourth qualification, but even that is lost when the plant is blown away. Shrubs retard erosion and have a low potential for wind tissue transport, but their root systems are deep. The ir radionuclide uptake is unknown.

Most natural plant communities are mixtures of plant species. Management strategies can usually be formulated to obtain the desired results under existing cost constraints.

The mammals of most concern for radionuclide transport from burial grounds are those species that are able to burrow deep into the backfill and bring radioactive debris to the soil surface. The badger is the most proficient burrowing mamal. Badgers can dig a meter or so below the surface, creating holes $15 \mathrm{~cm}$ or more in diameter and creating piles of earth about a meter in diameter and $0.3 \mathrm{~m}$ or more thick. Although badgers inhabit the Hanford Site, they occur in low numbers. They have not been observed to dig into the backfill of the 300 Area burial grounds. However, unless barriers are intentionally placed in burial grounds at a depth of $2.5 \mathrm{~m}$ or so to prevent deep burrowing, badgers may possibly exhume waste debris.

Pocket mice and ground squirrels spend much of their lifetime underground. Ground squirrels occur in localized colonies throughout the Hanford Site but have not been observed on 300 Area burial grounds. Pocket mice are found everywhere and populations reside on 300 Area burial grounds. Deer mice are found throughout the site but are not nearly as abundant as pocket mice. They reside on 300 Area burial grounds and occasionally have access to the buried waste, as indicated by special dosimetry studies.
Mule deer are present in bitterbrushcheatgrass vegetation habitats but are effectively excluded from entry into 300 Area burial grounds by a wire mesh fence. This prevents mule deer from eating plants growing in burial ground backfill. Black-tailed hares are also present in bitterbrushcheatgrass vegetation. The wire mesh fencing cannot exclude them because they can slip beneath it. Black-tailed hares cause concern in 300 Area burial grounds only if they consume plants with radionuclides derived from burial grounds or if they interfere with revegetation efforts to stabilize backfill with selected plant cover. Coyotes are present throughout the Hanford Site and are not excluded by fences. Coyotes are of concern if they should eat animals that have derived body burdens of radionuclides from buried waste.

Only a few birds nest on the backfill of 300 Area burial grounds. We expect that the western meadowlark, horned lark, mourning dove and western night hawk would find the 300 Area burial grounds acceptable but nests have not been found. These birds are of concern only if their adult and nestling diets include plant seeds, grit, or insects that contain radionuclides originating from the burial grounds.

Finally, ants are being studied because they seem to prefer backfill as sites for their colonies. Harvester ants are of special concern in waste management because they have the potential for digging into buried waste and bringing contaminated soil particles to the surface where they can be redistributed by wind. 


\section{- Service Assessment Studies}

Principal Investigators:

D. G. Watson and W. H. Rickard

Service Assessment studies, supported through the Richland Operations Office, involve the long-term ecological monitoring of several important animals likely to be impacted by the industrial development of the $1475 \mathrm{~km}^{2}$ Hanford Site. This report concerns spawning of chinook salmon studied in a series of observations now in its third decade.

\section{Fall Chinook Salmon Spawning Near Hanford, 1977}

Aerial surveys of fall chinook salmon (Oncorhynchus tshawytscha) spawning begun in $1 \overline{947}$ in the reach of the Columbia River from Richland, Washington (river $\mathrm{km} 546$ ) to Priest Rapids Dam ( $r$ iver $\mathrm{km}$ 638) were continued in 1977. Data from these estimates of the locally spawning salmon contribute to the baseline ecological information of the Hanford section of the Columbia River and are of potential use to fisheries management agencies (e.g., State of Washington
Department of Fisheries) or to local users of Columbia River water (e.g., Washington Public Power Supply System nuclear power plants).

Surveys were conducted in 1977 on 0ctober 13, 24 and 31 and November 7 and 10; the total number of redds (nests) observed was $42,919,1701,200$ (partial count) and 3153, respectively. The estimated total number of redds was 3240 , a little above the average observed during the past 15 years (Table 10.5). Fall chinook salmon spawning

TABLE 10.5. Fall Chinook Salmon Spawning, 1963-1977.

\begin{tabular}{|c|c|c|c|c|c|c|c|c|c|c|c|}
\hline \multirow[b]{2}{*}{ Year } & \multicolumn{6}{|c|}{ River Kilometer } & \multirow[b]{2}{*}{$\begin{array}{c}\text { Other } \\
\text { Location }\end{array}$} & \multicolumn{3}{|c|}{$\begin{array}{l}\text { Adult Dam Passage, } \\
\text { Number of Fish }\end{array}$} & \multirow[b]{2}{*}{$\begin{array}{l}\text { Hanford Spawner } \\
\text { as a Percent of } \\
\text { McNary Count (c) }\end{array}$} \\
\hline & $\begin{array}{c}354^{(a)} \\
\text { (Ringold) }\end{array}$ & $587-592$ & $\begin{array}{c}371 \\
\text { (White } \\
\text { Bluffs) }\end{array}$ & $373-376$ & $\begin{array}{c}383 \\
\text { (Coyote } \\
\text { Rapids) }\end{array}$ & $\begin{array}{c}393 \\
\text { (Midway) }\end{array}$ & & & $\begin{array}{l}\text { Bonneville } \\
\text { (Aug 1- } \\
\text { Dec 31) }\end{array}$ & $\begin{array}{l}\text { McNary } \\
\text { (Aug 9- } \\
\text { Oct 31) }\end{array}$ & \\
\hline & \multicolumn{7}{|c|}{ Number of Redds } & Total & & & \\
\hline 1963 & $0\langle 0)^{(b)}$ & $283(22)$ & $127(10)$ & $506(39)$ & $14(1)$ & $370(28)$ & $3(0.2)$ & 1303 & 139,075 & 57,363 & 16 \\
\hline 1964 & $5(0.3)$ & $163(11)$ & $111(8)$ & $510(35)$ & $37(3)$ & $624(42)$ & $27(2)$ & 1477 & 172,463 & 58,593 & 18 \\
\hline 1965 & $4(0.2)$ & $262(15)$ & $211(12)$ & $588(33)$ & $54(3)$ & $659(37)$ & $11(0.6)$ & 1789 & 157,694 & 76,326 & 16 \\
\hline 1966 & $10(0.3)$ & $279(9)$ & $267(9)$ & $1206(39)$ & $37(1)$ & $1300(42)$ & $2(0)$ & 3101 & 155,445 & 75,119 & 29 \\
\hline 1967 & $28(0.9)$ & $388(12)$ & $273(8)$ & $1192(36)$ & $17(0.5)$ & $1340(41)$ & $29(0.9)$ & 3267 & 185,643 & 73,087 & 31 \\
\hline 1968 & $117(3)$ & $595(17)$ & $188(5)$ & $1069(30)$ & $52(1)$ & $1520(43)$ & $39(1)$ & 3560 & 159,048 & 72,757 & 34 \\
\hline 1969 & $265(6)$ & $820(18)$ & $427(9)$ & $1446(32)$ & $50(1)$ & $1500(33)$ & $0(0)$ & 4508 & 231,828 & 79,375 & 40 \\
\hline 1970 & $107(3)$ & $615(16)$ & $302(8)$ & $1180(31)$ & $72(2)$ & $1528(40)$ & $9(0.2)$ & 3813 & 208,902 & 61,554 & 43 \\
\hline 1971 & $182(5)$ & $560(16)$ & $416(12)$ & $1071(30)$ & $10(0.3)$ & $1361(38)$ & $0(0)$ & 3600 & 202,274 & 69,718 & 36 \\
\hline 1972 & $88(10)$ & $247(28)$ & $147(17)$ & $259(30)$ & $4(0.5)$ & $131(0.5)$ & $0(0)$ & 876 & 137,486 & 49,307 & 12 \\
\hline 1973 & $137(5)$ & $458(15)$ & $179(6)$ & $1273(43)$ & $62(2)$ & $856(30)$ & $0(0)$ & 2965 & 211,127 & 73,253 & 28 \\
\hline 1974 & $104(14)$ & $156(21)$ & $49(7)$ & $238(33)$ & $5(0.7)$ & $173(24)$ & $3(6.4)$ & 728 & 186,328 & 62,009 & 8 \\
\hline 1975 & $95(4)$ & $458(17)$ & $291(11)$ & $252(9)$ & $91(3)$ & $995(37)$ & $1(0)$ & 2683 & 277,111 & 68,719 & 27 \\
\hline 1976 & $25(1)$ & $313(16)$ & $185(9)$ & $647(33)$ & $182(9)$ & $599(31)$ & $0(0)$ & 1951 & 325,312 & 87,991 & 16 \\
\hline 1977 & $15(0.5)$ & $473(15)$ & $355(11)$ & $1577(49)$ & $48(1)$ & $772(24)$ & $0(0)$ & 3240 & 206,126 & 84,370 & 27 \\
\hline
\end{tabular}


escapement to the Columbia as indicated by numbers of fish ascending the downstream Bonneville (river $\mathrm{km} 233$ ) and McNary (river $\mathrm{km}$ 470) dams also was good in 1977. The same areas continue to attract most of the spawning salmon in the Hanford reach. The areas near river km 587-592, 597-605 (White Bluffs to $100 \mathrm{D}$ Area) and 633 (Midway) contained approximately $99 \%$ of the redds observed.

In 1977, about $27 \%$ of the adult fall chinook salmon that passed over McNary Dam spawned in the Hanford section of the Columbia River. Approximately $2 \%$ of the
MCNary count went over Ice Harbor Dam on the lower Snake River, and $8 \%$ passed upriver of Hanford over Priest Rapids Dam. Of the remainder (63\%) that passed McNary Dam, a few probably spawned in the Yakima and Walla Walla Rivers that are tributaries to the Columbia between Hanford and McNary or were trapped to stock the spawning channel and incubation facility at Priest Rapids Dam. The bulk of these fish, however, were unaccounted for. The Hanford reach was the major spawning ground for fall chinook salmon in the mid-Columbia River in 1977. 
Energy Research for Other Agencies 


\title{
ENERGY RESEARCH FOR OTHER AGENCIES
}

\author{
Nuclear Regulatory Commission \\ Bonneville Power Administration \\ Electric Power Research Institute \\ National Institute of Environmental \\ and Health Sciences \\ National Oceanic and Atmospheric Administration/ \\ Bureau of Land Management
}

The purpose of this section is to correlate energy research conducted for other sponsors to U.S. DOE energy programs where interagency and other mutual agreements exist to support work on a nonduplicative basis. The research topics identified in this section are complementary to work discussed in other sections of this report. The data bases being developed provide a unique long-term reference for environmental and energy assessment in the arid West. Work performed under joint Environmental Protection Agency/Department of Energy agreements is discussed in Section 4.0, Oil and Gas. 


\section{Nuclear Regulatory Commission}

Biocide Byproducts in Aquatic Environments (Principal Investigators: $D$. R. Anderson, R. M. Bean, C. I. Gibson; Other Investigators: D. C. Mann, R. G. Riley, R. E. Shirmer; Specialists: C. S. Abernethy, K. Hanson, P. Wilkinson, D. L. Woodruff; Technical Assistance: M. G. Wolford)

More electrical generating plants are being built each year to meet additional demands for electricity. Assuming the continued use of chlorine as a biocide in power plants, the volume of chlorinated effluents entering aquatic environments will increase significantly. Associated with these effluents will be chlorinated (halogenated) organic byproducts.

This program is designed to further define an information base that can be used to develop or modify power plant regulations concerning chlorination or halogenation byproducts. This program is subdivided into analytical chemistry and biological tasks with freshwater and marine/estuarine subdivisions. The objectives of the analytical phase are to:

- identify those chemical compounds, other than the "free and combined available halogen," which result from the addition of chlorine to fresh or saltwater

- develop methods for detecting chlorinated hydrocarbons in the effluents discharged to receiving water bodies from nuclear stations

- verify laboratory findings through analysis for chlorination byproducts in water and biota samples from cooling-water bodies of nuclear power stations.

The objectives of the biological studies are to:

- investigate the immediate toxicity of specific chlorination byproducts, chloroform and bromoform

- investigate the chronic toxicity of chlorination byproducts

- investigate the bioaccumulation for chlorination byproducts

- follow their pathways of action in selected biota.

\section{Analytical Chemistry of Chlorination Byproducts}

Detailed analytical data have been obtained on the organohalogen contents of chlorinated freshwater from the Columbia River and seawater from Sequim Bay systems. Samples have been characterized with respect to 1) type and quantity of haloform produced from chlorination; 2) total organohalogen produced; 3) distribution of organohalogen by molecular weight and 4) distribution of organohalogen by polarity. In addition, a number of samples have been examined for individual halogenated components.

Our most recent measurements of haloform concentrations generated from 2 ppm chlorine additions to Columbia River water indicate that about 35 to $40 \mu \mathrm{g} / \ell$ (ppb) chloroform are formed, along with lesser amounts of bromodichloromethane. Similar chlorine additions to Sequim Bay seawater produced about $17 \mathrm{\mu g} / \ell$ bromoform, with lesser amounts of dibromochloromethane. Haloforms comprise at least $90 \%$ of the organically bound halogen formed from the freshwater and seawater samples studied, when chlorination is at the $2 \mathrm{ppm}$ level. Higher chlorine levels may produce a higher proportion of nonhaloform organohalogen material.

Almost all of the organically bound halogen from chlorinated waters is found in fractions having less than 800 molecular weight. Fractions containing greater than 800 molecular weight have very small or undetectable quantities of organic halogen. The nonhaloform organohalogen material produced appears to consist mainly of relatively polar constituents, i.e., more polar than PCB's, DDT, chloronaphthalenes, etc. There appears to be more nonpolar halogenated constituents generated from seawater chlorination than freshwater chlorination. Dichlorobenzene has been identified in a freshwater sample. 
In chlorinated Columbia River water, organochlorine is present in both phenol and acid fractions. Two dichlorophenols, trichlorophenol and bromochlorophenol have been identified by gas chromatography/mass spectrometry as products of freshwater chlorination. Figure 11.1 shows the single-ion chromatograms, obtained from a phenol sample, that clearly indicate the presence of the halogenated phenols, isolated as their acetyl derivatives.

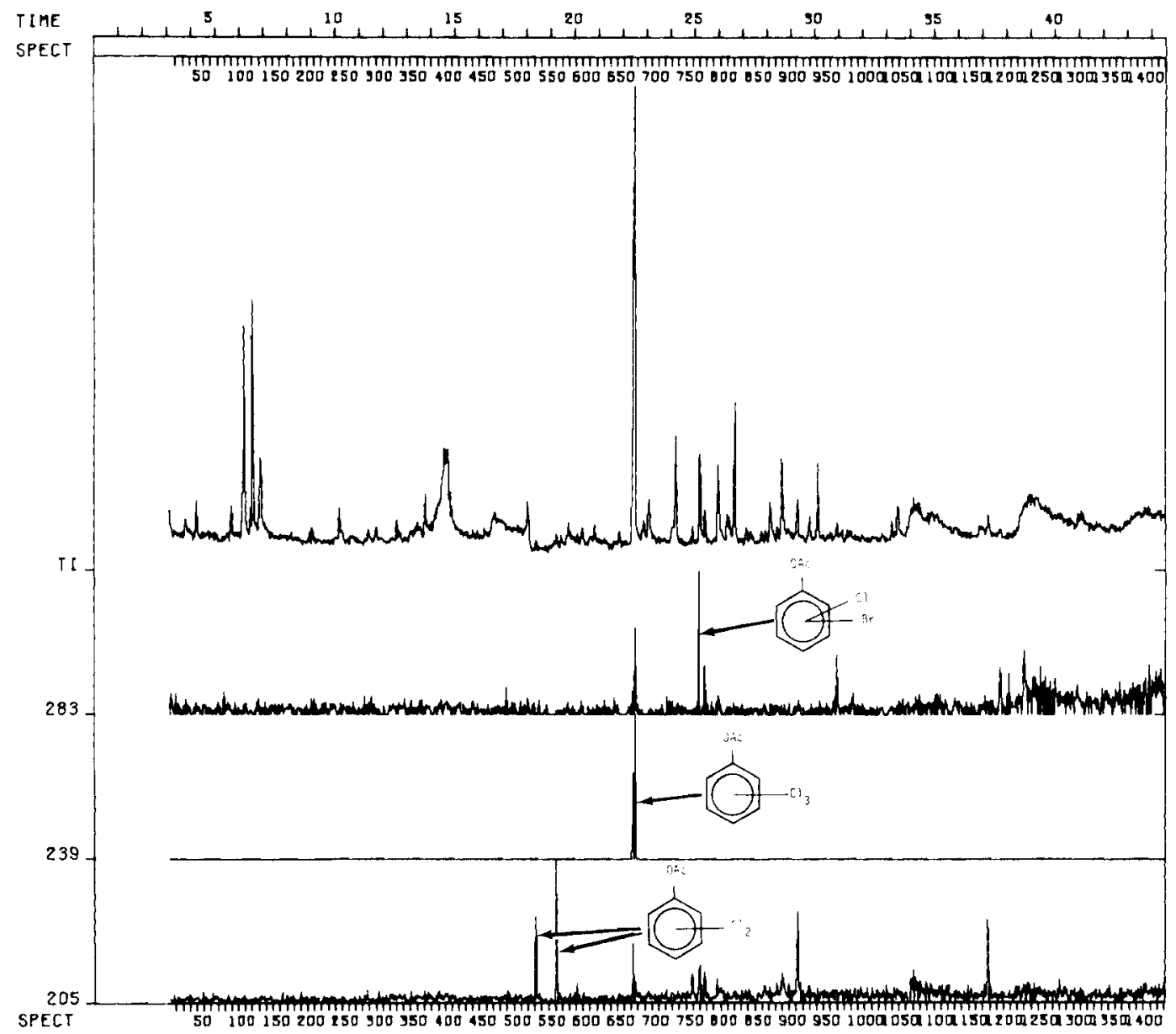

FIGURE 11.1. Single-ion Chromatograms Indicating the Presence of Halogenated Phenols, Isolated as Their Acetyl Derivatives.

The single-ion chromatograms clearly distinguish the phenols from interfering components in the total ionization scan (top chromatograms). Measurement of chloroform levels in freshwater exposure apparatus using the headspace technique has shown that chloroform levels range from $1 \mu \mathrm{g} / \mathrm{l}$ at $0.02 \mathrm{ppm}$ total residual chlorine (TRC1) to $0.5 \mu \mathrm{g} / \mathrm{l}$ at a $<0.002 \mathrm{ppm}$ TRC1. Chloroform concentrations in the unchlorinated controls range from nondetectable to $0.5 \mu \mathrm{g} / \mathrm{l}$. Preliminary studies indicate that there is no detectable difference in the levels of chloroform in trout tissue exposed to the highest test levels of chlorinated organics and the tissues of control trout. This observation, which needs further verification, is consistent with the small differences observed between chloroform levels in the exposure tanks.

We believe that the information that our present procedures are capable of generating will be particularly applicable to comparative studies of selected water resources across the United States which are now in progress. 


\section{Biological Studies of Chlorination Byproducts}

The objectives of the biological studies are to investigate 1) the relatively long-term effects of chlorination byproducts and 2) the immediate toxicity and the bioaccumulation of specific chlorination byproducts. Chloroform in freshwater and bromoform in saltwater are the specific chlorination byproducts that were used in toxicity tests and bioaccumulation studies with selected marine or freshwater biota. The chronic six-month chlorination byproduct tests in freshwater are conducted using rainbow trout (Salmo gairdneri). Littleneck clams (Protothaca staminea) are used in marine systems. The acute toxicity tests in freshwater are of chloroform on rainbow trout, bluegill (Lepomis macrochirus), largemouth bass (Micropterus salmoides) and channel catfish (Ictalurus punctatus). In marine systems, the acute toxicity studies are of bromoform on the littleneck clam, east coast oyster (Crassostrea virginica), quahaug (Mercenaria mercenaria) and brown shrimp (Penaeus aztecus).

Water treatment in the second freshwater six-month chronic chlorination byproduct bioassay system is designed to approximate the level of chlorination and thermal regime of a power plant. water is heated and chlorinated, then diluted and cooled before it enters the aquaria. Water is chlorinated at approximate power plant chlorination levels, that is, $1.5 \mathrm{ppm}$ total residual chlorine (TRC1), then diluted to a maximum concentration of $0.020 \mathrm{ppm}$ TRCl. Four other test concentrations $(75 \%, 50 \%, 25 \%$ and $12 \%$ ) are based on dilutions of the maximum concentration in addition to a control. Fish are sampled monthly to monitor growth and histological analysis.

The mortality rate throughout the test was low (less than one fish per week). There was an overall trend toward decreasing mortality with increasing concentrations. This may be due to a prophylactic effect of the chlorination byproducts. Further statistical analys is to verify this trend will be made, particularly during the disease-prone warm months of the year. During the first chronic bioassay, a hypothes is had been formed of a sublethal effect of chlorination byproducts on the behavior of rainbow trout. The results of the second bioassay tend to corroborate this hypothesis.

Acute toxicity tests with chloroform have been conducted on bluegill. Preliminary analysis of the results indicate a $96-\mathrm{hr}$ LC50 between 13 to $20 \mathrm{ppm}$ chloroform. Further $95-\mathrm{hr}$ chloroform toxicity tests are planned with bluegill, rainbow trout, channel catfish and largemouth bass.

A new toxicant delivery system (Figure 11.2) was developed for use with slightly soluble organic compounds such as chloroform. It consists of a continuous flow system using a glass column contact chamber filled with glass beads and a stirred mixing chamber that produces a

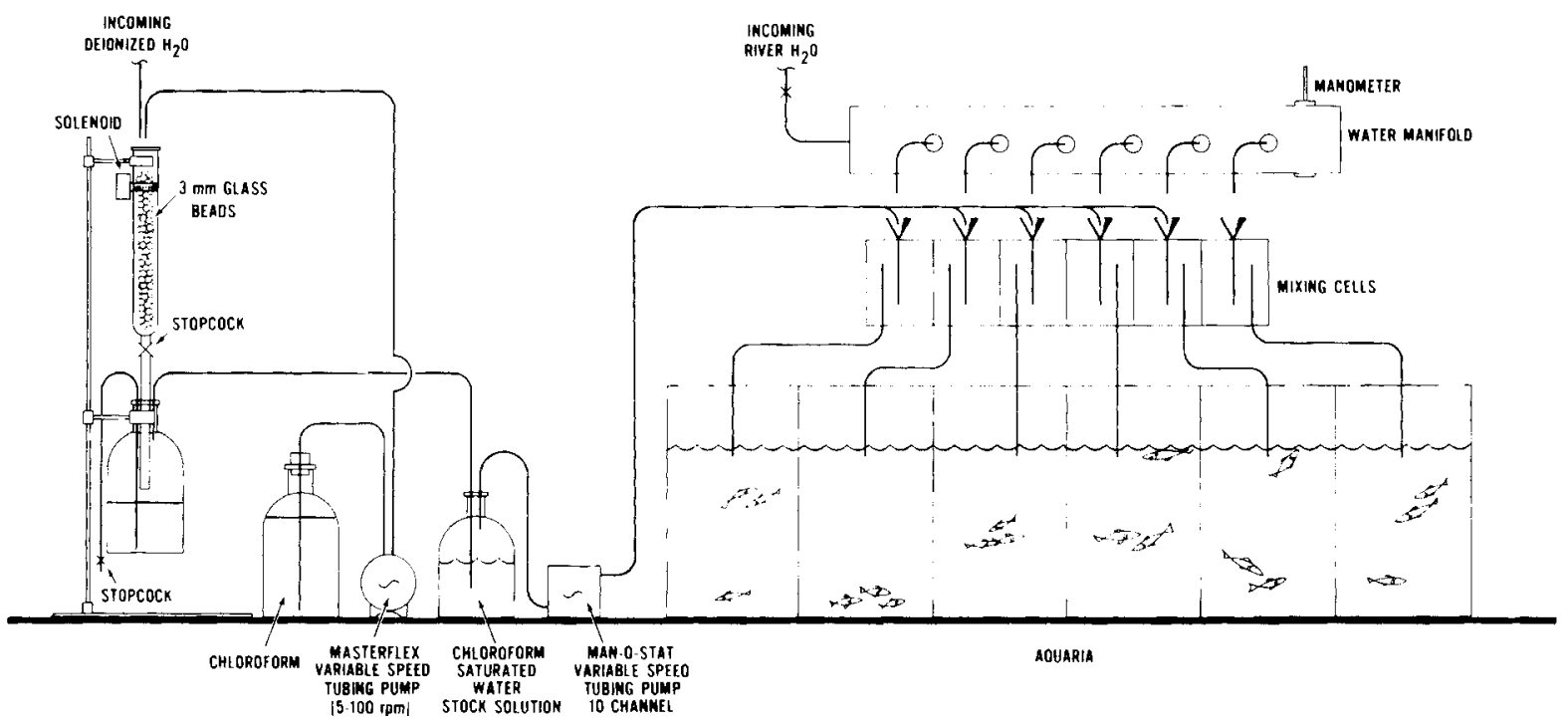

FIGURE 11.2. Toxicant Delivery System for Use with Slightly Solubie Organic Compounds. 
continuous flow of saturated stock solution. The stock solution is then pumped to the dilution chambers prior to entering the aquaria. This system eliminates the need for a solvent, e.g., acetone or alcohol, to dissolve slightly soluble toxicants.

In the marine study, the second chronic six-month exposure of littleneck clams to sublethal concentrations of chlorinated seawater was completed. Samples were collected monthly from each of the test concentrations (control, 100,50, 25, 12 and 6 ppb Total Residual 0xidant - TRO) for chemical and histological examination.

Acute bromoform toxicity and bioaccumulation exposures of littleneck clams indicated that the clams' first reaction, withdrawal of the siphons, occurred at $400 \mathrm{mg} / \ell$ bromoform. The clams resumed siphoning 60 min after the bromoform input was discontinued. A 28-day uptake/ 28-day depuration study was performed at several concentrations: $0,1,5,10$ and $20 \mathrm{mg} / \mathrm{l}$ bromoform. These bromoform levels are higher than those expected from chlorination of seawater. Bromoform is formed at $30 \mu \mathrm{g} / \mathrm{l}$ upon chlorinating seawater at a rate of $1.5 \mathrm{mg} / \mathrm{l}$. The uptakedepuration study indicates the LC50 is we 11 above $20 \mathrm{mg} / 2$ bromoform.

Two acute $96-\mathrm{hr}$ bromoform studies have been completed with brown shrimp at Battelle's Daytona Laboratory. A $96-h r \quad L C 50$ of $36 \mathrm{mg} / \ell$ was indicated for the first run and $31 \mathrm{mg} / \mathrm{for}$ the second run. These values are in close agreement and are much greater than levels expected to occur in the environment.

Shrimp exposed to bromoform exhibited the following reactions:

1. Within $60 \mathrm{sec}$ of the addition of bromoform and at all concentrations (nominal, 50, 40, 30 and $20 \mathrm{mg} / \mathrm{l}$ ) except $10 \mathrm{mg} / \ell$, the shrimp attempted to leave the tank or avoid the air stone through which the bromoform was entering.

2. The shrimp lost locomotion and equilibrium within 30 to 120 minutes in concentrations ranging from 50 to $20 \mathrm{mg} / \ell$ bromoform respectively. Narcosis did not occur at the $10 \mathrm{mg} / \mathrm{l}$ concentration or in the control.

3. A number of shrimp apparently recovered fully from the bromoform narcosis within $1 \mathrm{hr}$ after the flow of bromoform was discontinued.

The 28-day bromoform uptake/28-day depuration studies on oysters and hardshell clams at 20 , 10,5 and $1 \mathrm{mg} / \ell$ as well as mortality monitoring are under way. Results of these later studies have not been analyzed statistically at the time of this writing.

Application of Fisheries Management Techniques to Assessing Impacts (Principal Investigators: D. H. McKenzie, K. S. Baker, J. R. Skalski, K. L. Gore and D. H. Fickeisen)

This project was initiated to address the design and conduct of the ongoing monitoring programs at the nuclear power plant sites where minimal fisheries impact was .predicted. The objective of these monitoring efforts would be to detect large-scale or catastrophic departures from the predictions. The project efforts were directed toward reviewing and evaluating fisheries management techniques and case histories of their application, and toward determining their statistical properties and their ability to predict or document catastrophic changes in fish populations.

Because the main emphasis of the project was to identify methods that are independent of population simulation models and absolute abundance estimates, the efforts have focused on indices such as catch per unit effort, creel census, age and growth parameters, spawner recruit relationships and the morphoedaphic index. The advantages, disadvantages and site-specific requirements of each of these indices were discussed and recommendations were made for a potential combination of these indices to serve as the basis for a monitoring program.

Quantitative Assessment of Aquatic Impacts of Power Plants (Principal Investigators: D. H. McKenzie, K. L. Gore, K. S. Baker, J. R. Skalski, D. G. Watson, D. H. Fickeisen, L. D. Kannberg and E. M. Arnold)

Our efforts during the past fiscal year have been devoted to 1) evaluating the generic applicability of the statistical design developed during the previous year for phytoplankton, zooplankton and benthos; 2) evaluating fisheries monitoring techniques to determine their 
applicability to assessing impacts; 3) cooperating with the investigators from the University of Washington, Center for Quantitative Sciences, in examining aquatic simulation models for their applicability to predicting impacts and to aid in monitoring program design and 4) evaluating the design and analysis of monitoring programs for support of water quality modeling.

The project addressed the generic nature of the recommended sampling design, statistical analysis, and sample sizes for monitoring the lower trophic level organisms. These efforts confirmed that our earlier estimates of variance, developed from freshwater systems, are also applicable to the marine and riverine habitats. These findings have permitted us to prepare detailed recommendations for monitoring program design for the frequency of sampling and number of samples needed, and for the statistical methods of testing impact hypotheses. The recommendations include the magnitude of impact that monitoring programs should be designed to detect.

Our efforts to develop similar recommendations for monitoring fish populations have focused on reviewing and evaluating the commonly applied and available techniques. These techniques have been primarily adopted from fisheries management practices and they have not been critically examined in the arena of power plant impact assessment. Our review evaluates the ability of the various techniques to quantify impacts within the monitoring framework.

The review of fisheries models has focused on their mathematical formulation, their supportive data and rationale, and their predictive ability. our role has been to evaluate 1) the representation of the fisheries population dynamics in models; 2) the contribution that the monitoring program can make to the required data and 3) the usefulness of the models in designing the monitoring program.

A compendium of some 12 to 15 hydrothermal models representative of the state-of-the-art models in common use at nuclear power plants has been prepared. Among those described were hydrodynamic, radionuclide transport, water quality, thermal plume and Great Lake models. The structure, behavior and data needs of these models were discussed so that a prospective user could consult the compendium for guidance in designing a monitoring program to support the application of a specific model. Last year's work indicates that a monitoring program's design for supplying input and verification data to a hydrothermal model should reflect the model's resolution capabilities, its computational scheme, and its temporal (steady-state or transient) structure.

Two hydrodynamic models (one a finite difference model and one a finite element model) were applied to the Surry Nuclear Power Plant Site on the James River in Virginia. These applications were carried out to determine what demands might be made upon a monitoring program supplying data for these well-known and widely used models. The models were those of J. J. Leendertse of the Rand Corporation and Norton and King of Research Management Associates, respectively. In addition to determining the quality and density of the monitoring data necessary to insure reasonable model results, it was found that some types of irregularities in water body geometry cause the computational schemes to gain or lose mass. This finding implies that monitoring programs for a combination of hydrodynamic with transport or water quality models must pay close attention to water body geometry. A detailed report on the quantitative assessments of deviations from mass conservation has been prepared. It investigates the effects of boundary geometry, bathymetry and resolution of the discreditization process. Potential model users have been provided with a list of recommendations to enable them to minimize these deviations from mass continuity.

\section{Bonneville Power Administration}

Biological Studies at the Site of a 1200-KV Prototype Transmission Line (Principal Investigator: L. E. Rogers)

The transmission of electric power over ultrahigh voltage facilities, while technically feasible, will be more ecologically acceptable, and therefore used more frequently, if its possible environmental hazards are demonstrated to be relatively few or insignificant. The biological studies described here were designed for the Bonneville Power Administration to determine what effects, if any, a 1200-KV transmission system might have on its surrounding environment.

A test line was constructed near Lyons, Oregon in an area representative of the types of habitats commonly found west of the Cascade Mountain Range, including forests, meadows and agricultural lands. This permits an evaluation of possible biological effects in the field. 
The overal1 research strategy was to locate study areas both near or beneath the power 1 ine (treatment areas) and within areas located some distance away from the line (control areas). This permits a study of populations located in similar habitats and exposed to similar climatic factors yet enough removed from the power line to eliminate effects from electrical fields, corona discharge, noise, etc. Cattle, crop plants, coniferous and deciduous trees, shrubs, small mammals, birds, grass and honeybees were selected for study, being representative of the major ecological components of the Lyons study site. Studies of the crops, trees and honeybees are described below.

One of the most important observations to date is the lack of any gross deleterious biological effects following energization of the 1200-KV test 1 ine. The birds and mammals still 1 ive and forage beneath the lines. The trees and grasses appear normal, although some Douglas fir (Pseudotsuga menziesii) trees purposely left near the lines have shown some needle damage that appears to be associated with corona discharge points observed on the trees.

The cattle were at first bothered by the noise and vibration of the activated line, but they soon quieted and now appear to graze all portions of the pasture, both beneath and remote from the line, in about the same proportion. The honeybees also continue to forage, reproduce and produce honey and wax at about the same levels irrespective of proximity to the line. There were some growth differences among barley plants grown near and far from the line. The biological significance of these observations is not clear, however.

The general lack of observable adverse impacts associated with the 1200-KV test line does not mean that there are none. Studies are still in progress and many of the analyses can only be conducted after a complete data set becomes available. We would not expect to detect subtle biological effects before then.

\section{Crop Plant Studies}

Barley and peas were selected as the two crop plant species to be studied since they represent important forage crops, that is, grasses and legumes. The plants were grown in lysimeters $13 \mathrm{~cm}$ in diameter and $1 \mathrm{~m}$ deep. Some were located near the line and some farther away.

An average of $36.4 \pm 3.0(\bar{x} \pm S E)$ pea seeds were produced per treatment lysimeter as compared to $34.4 \pm 1.8$ for control lysimeters. Pea seed biomass values averaged $5.5 \pm 0.5$ and $5.9 \pm 0.2$ for treatment and control lysimeters respectively. Number and biomass of plant pods averaged $8.8 \pm 0.9$ and $2.0 \pm 0.2$ respectively for the treatment lysimeters and $7.7 \pm 0.4$ and $1.7 \pm 0.1$ for control 1ysimeters. None of these values are statistically significant $(\alpha 0.05)$ as determined by a t-test.

The results of plant growth analysis for barley plants is shown in Table 11.1. Plants contained in three of the ten control lysimeters were damaged by rodents and were not analyzed. Additional damage was prevented by elevating all treatment and control lysimeters a short distance above the ground. Culns and seed heads were longer and leaves shorter in plants grown near the line. These differences were significant ( $a .05)$. Seed head biomass values were not significantly different for the treatment and control areas. Straw production

TABLE 11.1. 1977 Barley Production and Growth Measurements (a) Beneath and at a Distance from a 1200-KV Power Line.(b)

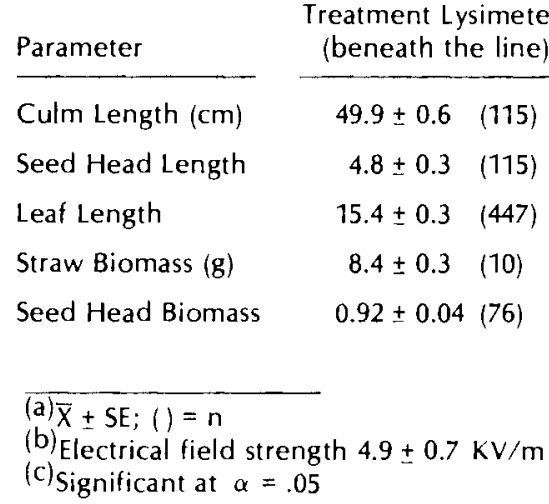


biomass, however, was significantly $(\alpha .05)$ greater in the treatment lysimeters $(8.4 \pm 0.3)$ than in the control lysimeters $(6.7 \pm 0.3)$. The biological significance of these differences is not known. Another season's results are needed to see if these differences are consistent or perhaps spurious.

\section{Tree Studies}

The dominant trees along the test line right-of-way include Douglas fir (Pseudotsuga menziesii) and Oregon oak (Quercus garryana). Tree growth patterns were measured by sampling current annual twig growth of both Douglas fir and oak trees. Trees were selected near the power line, away from the power line, and from a transect extending from near the power line to over $140 \mathrm{~m}$ away. Trees and brush were removed from the forest edge along the control area to simulate clearing activities that were required near the line (treatment areas) during construction.

The annual incremental growth of the top three whorls of 38 Douglas fir trees were measured in August 1976 (before energization) and August 1977 (after energization). Measurements were stratified by whor 1 and by terminal and lateral twig growth within each tree. This is necessary since the patterns of growth and electric field exposures is probably different within these strata.

A comparison of growth responses for Douglas fir trees in 1976 and 1977 is shown in Figure 11.3 as a function of distance from the line. Clearly growth during 1977 was less than in 1976 at all distances from the line, but not substantially different for trees near the line as compared to those farther away.

Observations during the August 1977 sampling session showed that the uppermost branches of some trees near the line had suffered needle tip burn. Photographs were taken of selected trees later using a Javelin ${ }^{\circledR}$ light amplifying device that clearly showed the presence of
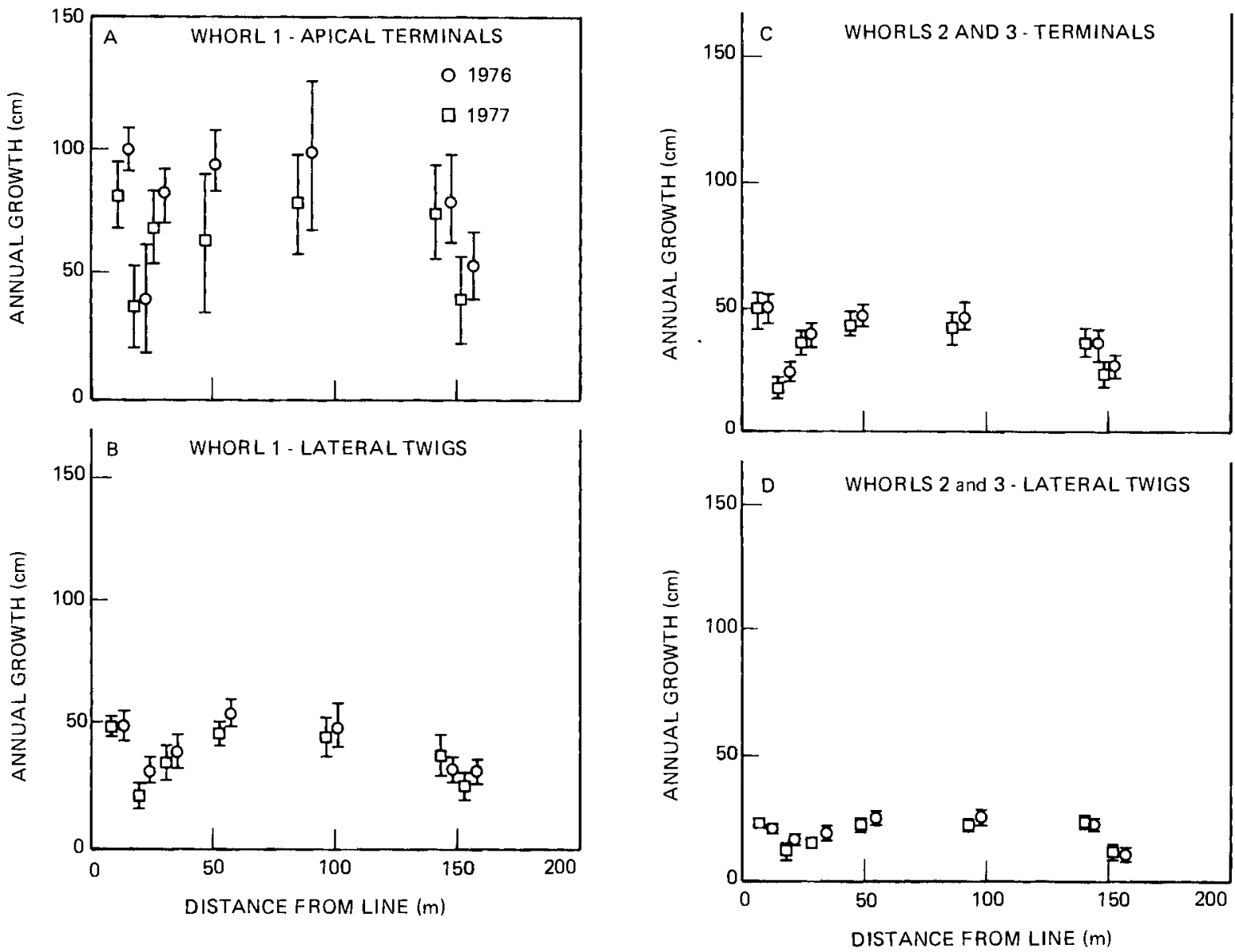

FIGURE 11.3. Annual Incremental Growth Patterns for Douglas Fir Trees as a Function of Distance from the Test Line. 
corona discharge points on some branches. The observed needle tip burn appears to be caused by physical damage associated with corona discharge.

Oak trees were sampled by measuring twig length growth in the tree canopy. Thirty measurements were made for each tree. The sampled branch was identified with flagging material permitting sampling of the same branch during succeeding years. Three oak trees were sampled near the line and three away from it. The average overall length of twigs from both treatment and control areas was smaller during 1977 (after energization) than in 1976 (before energization). The proportional growth of twigs during the two years, however, was nearly identical: $33 \%$ during 1976 and $84 \%$ during 1977. This suggests a lack of any major impact on oak twig growth in treatment areas.

\section{Honeybee Studies}

This task explored the possible effects of the 1200-KV power line on the establishment and maintenance of honeybee colonies located both beneath and remote from power line facilities. The strategy was to use equipment and techniques similar to those commonly employed by commercial beekeepers who might operate apiaries near power facilities. The parameters observed were production of honey and wax, reproduction and mortality rates.

Ten hives were placed in treatment and control areas in early April 1977. Honeybees were put into the hives and fed sugar water until they had become established.

An estimate of the reproductive vigor of colonies located both beneath and away from the power line was determined by periodically removing and photographing all brood frames within each colony. The photographic films were developed and a double sampling technique used to estimate the average number of capped brood cells per frame (Figure 11.4) The values for control colonies were consistently higher than treatment colony values, but the significance of these differences is not apparent at this time.

The periodic weight gain of both treatment and control colonies is shown in Table 11.2 for July through August 1977. The peak honey flow period occurred during late July and early August as expected.

TABLE 11.2. Honeybee Colony Weights, (a) 1977.

\begin{tabular}{|c|c|c|}
\hline Date & $\begin{array}{c}\text { Treatment } \\
\text { Colonies }\end{array}$ & $\begin{array}{l}\text { Control } \\
\text { Colonies }\end{array}$ \\
\hline July 5 & $48.5 \pm 4.1$ & $44.4 \pm 4.1$ \\
\hline July 13 & $54.4 \pm 5.4$ & $48.9 \pm 6.3$ \\
\hline July 20 & $54.8 \pm 5.9$ & $53.0 \pm 6.8$ \\
\hline July 27 & $54.8 \pm 5.4$ & $53.9 \pm 5.9$ \\
\hline Aug 3 & $54.4 \pm 5.4$ & $55.3 \pm 6.3$ \\
\hline Aug 10 & $51.2 \pm 5.0$ & $54.8 \pm 5.4$ \\
\hline Aug 17 & $50.3 \pm 5.0$ & $53.5 \pm 5.4$ \\
\hline
\end{tabular}

(a) Weights expressed as $\bar{X} \pm 5 E,(\mathrm{~kg})$.

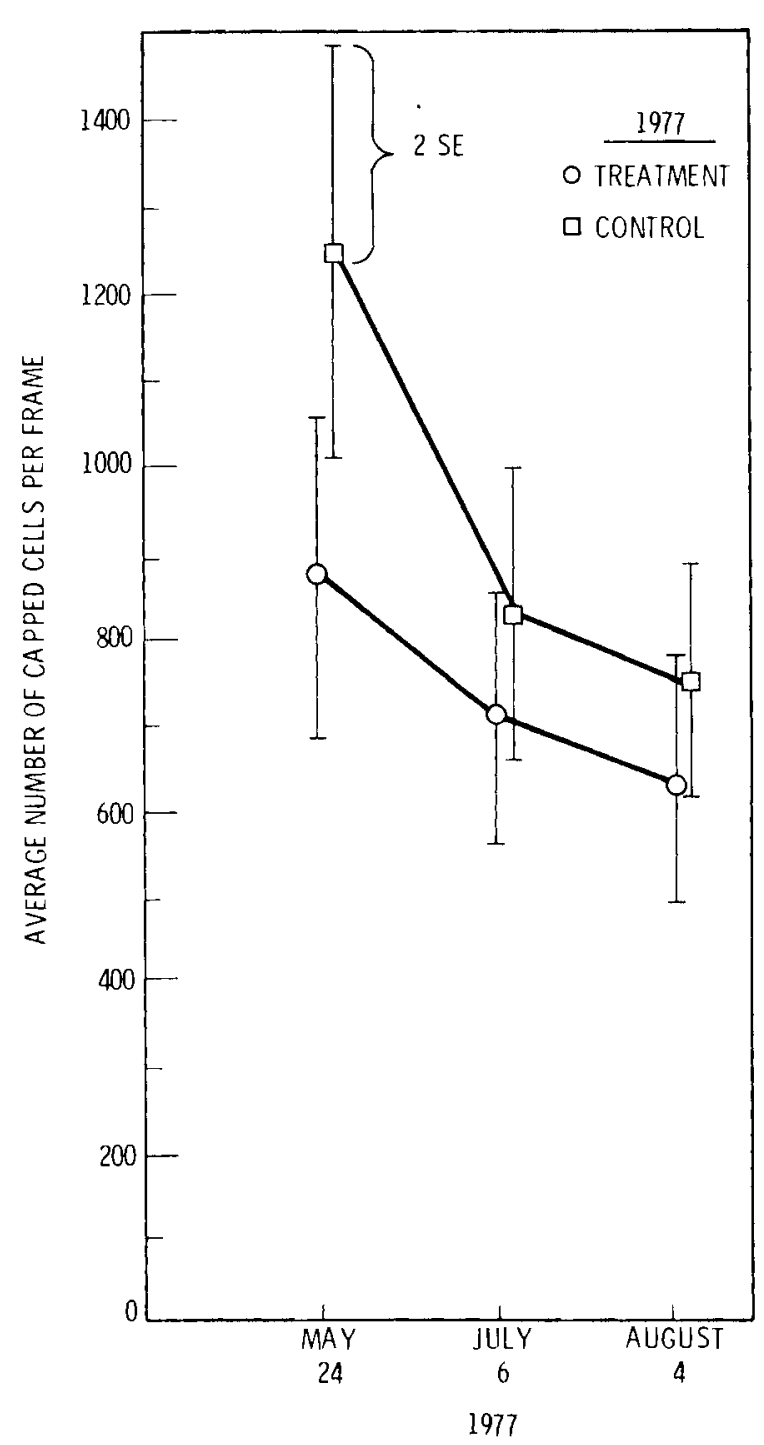

FIGURE 11.4. Estimated Number of Honeybee Capped Brood Cells. 
The estimated total production of wax averaged $1.4 \pm 0.3 \mathrm{~kg}$ for colonies located near the line and $1.3 \pm 0.1 \mathrm{~kg}$ for control colonies. Honey production averaged $14.1 \pm 1.3 \mathrm{~kg}$ per colony near the ?ine and $13.0 \pm 2.4 \mathrm{~kg}$ per colony for those located away from the power line. Neither the wax nor the honey values were significantly different between treatment and control colonies $(\alpha .05$, t-test).

Dead bee traps were installed on August 4, 1977. Three were placed on colonies located near the line and three on control colonies of equivalent size. Mortality counts for both control and treatment areas appeared to be about the same. Mortality was highest during the first day of sampling for both treatment and control hives. This may have been associated with brood production estimating techniques. The colonies had been opened the previous day to permit photography of the brood frames and some bees always die during colony manipulations. The power line was de-energized during mortality sampling periods since the dead bee traps are metal and could influence the results.

\section{Electric Power Research Institute}

Synthesis and Analysis of Cooling Impoundment Information (Principal Investigators: C. D. Becker, K. L. Gore and C. E. Cushing)

A literature review and assessment study was begun in 1977 to examine the ecological impact of a once-through cooling mode of power plant operation on cooling impoundments, which represent essentially closed aquatic ecosystems. The primary objectives were to 1) synthesize ecological data from small impoundments, 2) analyze the data for impacts on plant operations, 3) identify what important effects could not be assessed and 4) extrapolate the conclusions to other types of aquatic ecosystems.

Fourteen cooling impoundments were selected for evaluation on the basis of physical criteria and the available ecological references. The primary physical effect was the increment of surplus heat from plant condensers to the water body. Chemical changes were minimal, and usually associated with the natural, long-term evaporation of water. Biological effects were largely qualitative, limited to a portion of the fish and plankton populations, and were not reflected at the population, community or ecosystem level. Most studies were inadequately designed to quantify potential ecological impacts from power plant operation. However, even small cooling impoundments with a relatively heavy heat burden apparently sustain viable, reproducing populations of organisms.

Effects of Coal-Fired Power Plant Emissions on Vegetation in the Western U.S. (Principal Investigator: M. L. Warner)

During 1978 Battelle researchers conducted a brief preliminary survey of current research on possible effects of emissions from coal-fired power plants in the western U.S. on vegetation, particularly crops. The study was conducted to assist the Electric Power Research Institute (EPRI) in determining how future research funded by EPRI might have the greatest possible impact. The resulting study report (a) summarized findings on the state of current research on the effect of emissions on vegetation, listed 45 current research projects, summarized the major relevant findings of 105 references selected for review, and suggested priorities for future EPRI-funded research.

The study was conducted as a preliminary overview of the field, based on limited literature reviews and discussions with other researchers and utility representatives. A more complete critical review of all relevant literature and on-going work was beyond the scope of the effort. Indeed, one of the purposes of this project was to identify topics for which such exhaustive examination might be desirable.

(a)Warner, M. L., 1978, Effects of coal-fired power plant emissions on vegetation in the western U.S. Prepared for the Electric Power Research Institute by Battelle, Pacific Northwest Laboratories, Richland, WA, 22 pp. 


\section{National Oceanic and Atmospheric Administration/ Bureau of Land Management}

Accumulation of Organic Constituents and Heavy Metals from Petroleum Impacted Sediments by Marine Detritivores (Principal Investigator: J. W. Anderson)

This research complements that conducted under U.S. DOE funding, since it relates to bioavailability of hydrocarbons from sediment. While the techniques and organisms differ, the findings will help us to evaluate the fate and effects of petroleum hydrocarbons in marine organisms and the marine environment.

Research on the bioavailability of hydrocarbons and trace metals from oil-impacted sediments during FY 1977 and FY 1978 has resulted in publication or submission of the major reports and articles listed below:

\section{Reports}

Anderson, J. W., Roesijadi, G., Woodruff, D. L. and Crecelius, E. A. 1977. Accumulation of organic constituents and heavy metals from petroleum-impacted sediments by marine detritivores. Annual Report to NOAA, Juneau, Alaska.

Anderson, J. W., Roesijadi, G. and Crecelius, E. A. 1977. Bioavailability of hydrocarbons and heavy metals to marine detritivores from oil-impacted sediments. In Environmental assessment of the Alaskan continental shelf, Vol. XII, Effects, pp. 770-822. U.S. Department of Commerce, NOAA.

Anderson, J. W., Augenfeld, J. M., Crecelius, E. A. and Riley, R. 1978. Research to determine the accumulation of organic constituents and heavy metals from petroleum-impacted sediments by marine detritivores of the Alaskan outer continental shelf. Annual Report to NOAA, Juneau, Alaska.

\section{Publications}

Roesijadi, G., Woodruff, D. L. and Anderson, J. W. 1977. Bioavailability of naphthalenes from marine sediments artificially contaminated with Prudhoe Bay crude oil. Environmental Pollution 15: 223-229.

Roesijadi, G., Anderson, J. W. and Blaylock, J. W. 1978. Uptake of hydrocarbons from marine sediments contaminated with Prudhoe Bay crude oil: Influence of feeding type of test species and availability of polycyclic aromatic hydrocarbons. Journal of the Fisheries Research Board of Canada 35: 608-614.

Roesijadi, G. and Anderson, J.W. In press. Condition index and free amino acid content of Macoma inquinata exposed to oil-contaminated marine sediments. To be published in 1977 symposium on pollution and physiology of marine organisms, ed. W. Vernberg and F. J. Vernberg. New York: Academic Press.

Effects of Petroleum Hydrocarbons on the Behavior of Dungeness Crabs (Principal Investigators: W. H. Pearson and J. W. Anderson)

In cooperation with Bori $011 \mathrm{a}$, Chief of Behavioral Investigations at the National Marine Fisheries Service in Sandy Hook, New Jersey, we are investigating the effects of petroleum hydrocarbons on chemoreception and behavior in marine organisms. The initial studies are on the Dungeness crab (Cancer magister), biue crab (Callenectes sapidus) and hake (Uorphycis chuss). During the first year, the research has concentrated on obtaining baseline data on the detection limits of these organisms for sapid solutions (food extracts), specific petroleum hydrocarbon compounds, and the water-soluble fraction (WSF) of whole crude oil. We have found that the Dungeness crab can detect clam extract at approximately $10-10 \mathrm{~g} / \mathrm{l}$ concentrations and naphthalenes at $10^{-8} \mathrm{~g} / \mathrm{l}$. The blue crab has slightly higher sensitivities and can detect clam extract at $10^{-15} \mathrm{~g} / \mathrm{l}$ and naphthalenes at $10^{-10} \mathrm{~g} / \ell$. WSF detection levels have not been calculated yet. The initial behavioral activities elicited by both clam extract and pletroleum hydrocarbons are the same.

In the upcoming year, attraction/avoidance studies are planned. These studies will provide information needed to predict the potential for crabs being attracted to oiled areas and becoming contaminated, or for their avoiding oil contaminated areas and thus losing habitat 
space. In addition, studies are planned that will determine if the exposure to oil interferes with the crabs' ability to find food items or perform other important behaviorial activities such as location of mates.

This research has resulted in a report and a journal article:

011 a, B. L., Pearson, W. H. and Anderson, J. W. 1978. The effects of petroleum hydrocarbons on chemoreception in marine organisms. I. Dungeness crab, Cancer magister. 1978 Progress Report to NOAA.

Pearson, W. H., Sugarman, P. C., Woodruff, D. L. and 011 a, B. L. 1979. Thresholds for detection and feeding behavior in the Dungeness crab, Cancer magister (Dana). Submitted to Journal of Experimental Biology and Ecology.

\section{National Institute of Environmental and Health Sciences}

Fate of Heavy Metals and Heavy Metal Complexes in Soils and Plants (Principal Investigator: R. E. Wildung)

The program under way for the National Institute of Environmental Health Sciences is directed toward understanding the influence of soil, microbial and plant physiological processes on the form and behavior in soils and plants of trace metals arising from energy production.

Trace elements may enter the environment as a result of extraction, combustion, upgrading and refining of fossil fuels, production of synfuels, and the utilization of geothermal energy. Little is known of the effects on the environment and on human health resulting from alteration of the sensitive concentration balance of trace metals in the environment, as investigations of these phenomena are relatively recent. However, a background of information to predict the behavior of these elements is available from studies of radionuclides. Furthermore, use of radiotracers is essential to studies of trace metals where problems of contamination and detection require rapid, sensitive and specific detection methods.

The studies are providing an integrated view of the potential for trace metal-organometal complex formation in soil, uptake by plants, localization in edible tissues and gastrointestinal transfer in animals. This information has provided a basis for assessment of problems associated with entrace of trace metals into the environment as a result of energy production and a unique insight into the effect of similar transformations on the long-term behavior of radionuclides. Nuclear science has, in turn, provided the tools and a part of the background necessary to conduct experiments appropriate to development of this understanding. 
Publications
and
Presentations 


\section{PUBLICATIONS}

Abe1, K.H., Robertson, D.E., Crecelius, E.A., and Silker, W.B. 1978. Speciation studies of radionuclides in low level wastes and process waters from a pressurized water reactor. In: Proceedings of the 4th Joint Conference on Sensing of Environmental Pollutants. American Chemical Society, Washington, DC.

Abernethy, C.S., and Lund, J.E. 1978. Mycobacteriosis in mountain whitefish (Prosopium williamsoni) from the Yakima River, Washington. J. Wildlife Diseases $14: 333-336$.

Anderson, D.R. 1978. Toxicity of Transformer Fluids: FC-75, Dichloroethyne, Tetrachloroethylene and Sulfur Hexafluoride to Aquatic Biota - A Review. A Report to Electric Power Research Institute, 3412 Hillview Avenue, Palo Alto, CA.

Anderson, D.R., and Thatcher, T.0. 1977. Contrasts between chlorination effects in freshwater and seawater environments. Proc. Annual Conf. West. Assoc. State Game Fish Comm. 57:324-325.

Anderson, J.W. 1978. Editorial. Marine Environmental Research 1(1).

Anderson, J.W. 1978. An assessment of knowledge concerning the fate and effects of petroleum hydrocarbons in the marine environment. In: Proceedings of the Symposium on Pollution and Physiology of Marine Organisms, November 1977. Academic Press, NY, in press.

Anderson, J.W., Augenfeld, J.M., Crecelius, E.A., and Riley, R.G. 1978. Research to Determine the Accumulation of Organic Constituents and Heavy Metals From Petroleum-impacted Sediments by Marine Detritivores of the Alaskan Outer Continental Shelf. Progress Report of Research Unit 454 of NOAA/BLM OCSEAP Program, Juneau, Alaska, Apri1, 1978. NOAA Technical Report Series.

Anderson, J.W., and Kiesser, S.L. 1978. Comparative uptake of naphthalenes from water and oiled sediment by benthic amphipods. Paper accepted for the $19790 i 1$ Spil1 Conference, March 19-22, Los Angeles, CA.

Anderson, J.W., and Malins, D.C. 1978. Physiological stresses and response in chronically oiled organisms. J. Fish. Res. Board Can. 35(5):679-680.
Anderson, J.W., Riley, R.G., and Bean, R.M. 1978. Recruitment of benthic animals as a function of petroleum hydrocarbon concentrations in the sediment. J. Fish. Res. Board Can. 35(5):776-790.

Augenfeld, J.M. 1978. The relation of habitat to glycogen concentration and glycogen synthetase in polychaetes. Marine Biology 48:57-62.

Bean, R.M., Blaylock, J.W., and Riley, R.G., 1978. Application of trace analytical techniques to a study of hydrocarbon composition upon dispersion of petroleum in a flowing seawater system. In: Preprints, Division of Petroleum Chemistry, ACS Symposium, 176 National Meeting, pp. 902-908. American Chemical Society, Washington, DC.

Bean, R.M., Riley, R.G., and Ryan, P.W. 1978. Investigation of halogenated components formed from chlorination of estuarine water. In: Water Chlorination; Environmental Impact and Health Effects, Vol. 2, ed. R.L. Jolley, H. Gorchev, and D.H. Hamilton, Jr., pp. 223-234. Ann Arbor Science, Ann Arbor, MI.

Bean, R.M., Ryan, P.W., and Riley, R.G. 1978. Investigation of trace organic components in chlorinated natural waters using glass WCOT columns. In: Proceedings of the Symposium on High Resolution Gas Chromatography. American Chemical Society, Academic Press.

Cataldo, D.A. 1978. Behavior of $T C$ and $I$ in a Hanford Soil and Associated Subsoil: Influence of Soil Aging on Uptake by Cheatgrass and Tumbleweed. DOE Report PNL-2740, in review.

Cataldo, D.A. 1978. Comparative Availability of $\mathrm{CS}$ and $\mathrm{Sr}$ for PT ant Absorption from Amended Rupert Surf ace Soil and Associated Subsoil: Influence of Growth Conditions. DOE Report PNL-2741, in review.

Cataldo, D.A., Routson, R.C., Paine, D., and Garland, T.R. 1978. Relationships Between Properties of Hanford Soils and the Availability of Cs and $\mathrm{Sr}$ for uptake by Cheatgrass and Tumbleweed. DOE Report PNL-2496. 
Cataldo, D.A., Garland, T.R., and Wildung, R.E. 1978. Foliar absorption of transuranic elements: Effects of chemical forms and environmental factors. J. Environ. Qual., submitted.

Cataldo, D.A., Garland, T.R., and Wildung, R.E. 1978. Nickel in plants: I. Uptake kinetics using intact soybean seedlings. Plant Physiol. 62:563-565.

Cataldo, D.A., Garland, T.R., and Wildung, R.E. 1978. Retention and leachability of submicron plutonium and americium particles associated with plant foliage. J. Environ. qual., submitted.

Cataldo, D.A., Garland, T.R., Wildung, R.E., and Drucker, H. 1978. Nickel in plants: II. Distribution and chemical forms in soybean plants. Plant Physiol. 62:566-570.

Cataldo, D.A., and Vaughan, B.E. 1978. Interaction of airborne plutonium with plant foliage. In: Transuranic Elements in the Environment, ed.W.C. Hanson, TID-22800, in press.

Cataldo, D.A., and Wildung, R.E. 1978. Soil and plant factors influencing the accumulation of heavy metals by plants. Environ. Health Perspectives.

Cline, J.F., and Holter, G.M. 1978. The effect of soil affixants on germination, emergence, and growth of cheatgrass and russian thistle. Health Phys. 35(2):409-411.

Cline, J.F., and Uresk, V.A. 1978. Revegetation of disturbed grounds in the semi arid climate of southcentral

Washington. Health Phys. 35(2):409-411.

Connors, T.J., Schneider, M.J., Genoway, R.G., and Barraclough, S.A. 1978. Effects of acclimation temperature on plasma levels of glucose and lactate in rainbow trout, Salmo gairdneri. J. Experimental Zoology, accepted.

Crecelius, E.A., Roesijadi, G., and Thatcher, T.0. 1978. Errors in determination of residual oxidants in chlor inated seawater. Environ. Sci. and Tech., in press.

Cummins, K.W., Sede11, J.R., Swanson, F.J., Fisher, S.A., Vannote, R.L., Minshal1, G.W., Cushing, C.E., and Petersen, R.C. 1978. Problems in evaluating organic matter budgets for stream ecosystems. Hydrobiologia, submitted.
Cushing, C.E. 1978. Trace elements in a Columbia River food web. Northwest Science, accepted.

Dauble, D.D., Gray, R.H., Hanf, R.W., Jr. and Poston, T.M. 1978. Occurrence of a wild albino chinook (Oncorhynchus tshawytscha) in the Columbia River. Northwest Sci. 5?(2): 108-109.

Dauble, D.D., Gray, R.H., and Page, T.L. 1978. Importance of insects and zooplankton in the diet of 0 -age chinook salmon (Oncorhynchus tshawytscha) in the central Columbia River, submitted.

Delfiner, P., and Gilbert, R.0. 1978. Combining two types of survey data for estimating geographical distribution of plutonium in area 13 . Selected Environmental Plutonium Research Papers of the NAEG, ed. M.G. White and P.B. Dunaway, NVO-192, Las Vegas, NV, in press.

Doctor, P.G., and Gilbert, R.0. 1978. Two studies in variability for soil

concentrations: with aliquot size and with distance. In: Selected Environmental Plutonium Research Papers of the NAEG, ed. M.G. White and P.B. Dunaway, NVO-192, Las Vegas, NV, in press.

Doctor, P.G., Gilbert, R.0., Pinder, J.E., and Eberhardt, L.... 1978. Appropriate use of ratios in environmental transuranic studies. In: Transuranic Elements in the Environment, ed. W.C. Hanson, TID-22800, in press.

Drucker, H., Garland, T.R., and Wildung, R.E. 1978. Bacterial genera, metal resistance and metal modification. In: Abstracts of Annual Meetings of American Society for Microbiology. Las Vegas, NV.

Drucker, H., Garland, T.R., and Wildung, R.E. 1978. Role of soil microbiota in chromium modification. In: Proceedings Intra-Science Symposium on Trace Metals in Health and Disease, Santa Monica, CA.

Eberhardt, L.L. 1978. Applied systems ecology: models, data and statistical methods. In: New Directions in the Analys is of Ecological Systems, Part 1., ed. G.S. Innis, Pp. 43-55. Society for Computer Simulation, LaJolla, CA.

Eberhardt, L.L. Appraising variability in population studies. J. Wildl. Manage. 42(2):207-238.

Eberhardt, L.L. 1978. Designing ecological studies of trace substances. In:

Environmental Chemistry and Cycling

Processes, ed. D.C. Adriano and

I.L. Brisbin, CONF-760429. 
Eberhardt, L.L. 1978. Determining optimal levels for marine mammals. In: Dynamics in Large Mammal Populations, ed. C. Fowler and T. Smith, Wiley-Interscience, NY, in press.

Eberhardt, L.L. 1978. Line transects based on right-angle distances. J. Wildl. Manage., in press.

Eberhardt, L.L. 1978. Transect methods for population studies. J. Wildl. Manage. $42(1): 1-31$.

Eberhardt, L.L., Chapman, D.G., Gilbert, J.R. 1978. A review of marine mammals census methods. Wildlife Monographs, accepted.

Eberhardt, L.L., and Gilbert, R.0. 1978. Statistics and sampling in transuranic studies. In: Transuranic elements in the Environment, ed.W.C. Hanson, TID-22800, in press.

Emery, R.M. 1978. A theoretical expression for resuspension applied to sedimentation processes in lakes. In: Proceedings of the $X X$ Congress, International Society of Theoretical and Applied Limnology, in press.

Emery, R.M., Klopfer, D.C., and McShane, M.C. 1978. The ecological export of plutonium from reprocessing waste ponds. Health Phys., 34:?55-269.

Emery, R.M., and McShane, M.C. 1978. Comparative Ecology of Nuclear Waste Ponds and Streams on the Hanford Site. DOE Report PNL-2499.

Fickeisen, D.H. 1978. Pumped Storage Environmental Effects: Assessment of Research Needs. DOE Report PNL-267T.

Fickeisen, D.H., and Montgomery, J.C. 1978. Tolerances of fishes to dissolved gas supersaturation in deep tank bioassays. Trans. Am. Fish. Soc. 107(2):376-381.

Fitzner, R.E. 1978. Time-1apse photography for field studies of raptorial birds. In: National Environmental Research Park Symposium: Natural Resource Inventory, Characterization, and Analys is, ed. J.T. Kitchings, and N.E. Tarr, DOE Report ORNL -5304 .

Fitzner, R.E. 1978. A winter record of the white-fronted goose in eastern Washington. The Murrelet 58(3):89.

Fitzner, R.E., Gano, K.A., Rickard, W.H., and Rogers, L.E. Ecological Characterization of the 300 Area Waste Burial Sites. DOE Report PNL-2774, in press.
Fitzner, R.E., and Hanson, W.C. 1978. A congregation of wintering bald eagles. The Condor, submitted.

Fitzner, R.E., Martin, D.F., and Frieze, K.E. 1978. First breeding record of the Great Egret (Casmeriodius allus) in Washington. The Murrelet, in press.

Fitzner, R.E., Rickard, W.H., and Clark, D.E. 1978. Herpetological survey of the Trojan Nuclear Power Plant, Oregon. Northwest Sci. 52:104-107.

Fitzner, R.E., and Rogers, L.E. 1978. Raptors and other birds of the Boardman electric power generating site and environs, Morrow County, Oregon. Western Birds, submitted.

Fitzner, R.E., Rogers, L.E., and Uresk, D.W. 1978. Techniques useful for determining raptor prey-species abundance. Raptor Research 11:57-71.

Fitzner, R.E., and Schreckhise, R.G. 1978. Radioecology of the American Coot (Fulica americana) in southeastern Washington Part 1: Nesting Biology. DOE Report PNL-2462.

Garland, T.R., Wildung, R.E., and Harbert, H.P. 1978. Mobility of macro-ions, trace elements, and organic components after application of irrigation water to lysimeters containing retorted oil shale. In: Agronomy Abstracts, ASA, SSSA and CSSA Annual Meetings.

Gilbert, R.0. 1978. TRAN-STAT: Statistics for Environmental Transuranic Studies. DOE Reports, PNL-SA-6697, February, PNL-SA-6902, April.

Gilbert, R.0., and Eberhardt, L.L. 1978. Statistical design and analyses for NAEG studies: Current status and a review of past efforts. In: Selected Environmental Plutonium Research Papers of the NAEG, ed. M.G. White and P.B. Dunaway, NVO-192, Las Vegas, NV, in press.

Gore, K.L., Thomas, J.M. and Watson, D.G. 1978. Quantitative evaluation of environmental impact assessment, based on aquatic monitoring programs at three nuclear power plants. J. Environ. Manage. 7.

Gray, R.H. 1978. Avoidance of thermal effluent by juvenile chinook salmon (Oncorhynchus tshawytscha) and its implications in waste heat management. In: Proceedings Waste Heat Management and Utilization Conference Vol. 3, ed. S.S. Lee and S. Sengupta, University of Miami, FL. 
Gray, R.H. 1978. Microfouling in ocean thermal energy conversion units. In: Proceedings of the Colloid and Surface Science Symposium. Abstract, American Chemical Society, Washington, DC.

Gray, R.H. 1978. Nondifferential predation susceptibility and behavorial selection in three color morphs of Illinois cricket frogs (Acris crepitans). Transactions Illinois State Academy of Sciences, in press.

Gray, R.H., ed. 1978. Proceedings of the Ocean Thermal Energy Conversion (OTEC) Biofouling and Corrosion Symposium, DOE Report, CONF-771001.

Gray, R.H., and Haynes, J.M. 1978. Effects of external and internal radiotransmitter attachment of adult chinook salmon, Oncorhynchus tshawytscha. J. Fish. Res. Board Can., in press.

Gray, R.H., and Haynes, J.M. 1978. In-situ swimming depth of spring and fall run chinook salmon Oncorhynchus tshawytscha in relation to gas supersaturated water. In: Proceedings of the American Fisheries Society Meeting, September 1977.

Gurtisen, J.M., Crecelius, E.A., Abel, K.H., and Philbrick, C.W. 1978. Copper complexing capacity of Pacific Northwest coastal waters. In: Proceedings of Workshop on Copper in Estuarine, Continental and Marine Waters, abstract, p. 17, CONF-771236.

Haynes, J.M. 1978. Movement and Habitat Studies of Chinook Salmon and White Sturgeon, DOE Report PNL-2471.

Haynes, J.M., and Gray, R.H. Influence of Little Goose Dam on upstream migration of chinook salmon (Oncorhynchus tshawytscha). Fish Bull., in press.

Haynes, J.M., Gray, R.H. and Montgomery, J.C. Diurnal and seasonal white sturgeon (Acipenser transmontanus) movements in relation to Columbia River temperatures, submitted.

Haynes, J.M., Gray, R.H., and Montgomery, J.C. 1978. Seasonal and diurnal movements of radio-tagged White Sturgeon (Acipenser transmontanus) in relation to mic-columbia river temperatures. In: Abstracts of 108th Annual Meeting of American Fisheries Society, P.0. Box 1150, Columbia, MD.

Haynes, J.M., Gray, R.H. and Montgomery, J.C. 1978. Seasonal location and movement of white sturgeon (Acipenser transmontanus) in the mid-Columbia River. Trans. Am. Fish. Soc. $107(2): 275-280$.
Hedlund, J.D., and Rogers, L.E. 1978. A population of great basin pocket mice (Perognathus parvus), in the vicinity of radioactive waste management areas at Hanford--South Central WA, Northwest Sci., submitted.

Hinds, W.T. 1978. National natural areas for research: where and why?, Environmental Conservation, submitted.

Hinds, W.T., Cline, J.F., and Schreckhise, R.G. 1978. Techniques for long-term field studies on plant uptake of transuranics from soil, Health Phys., in press.

Hinds, W.T., and Rotenberry, J.T. 1978. The relationship between mean and extreme temperatures in diverse microclimates. Nature, submitted.

Justesen, D.R., Ragan, H.A., Rogers, L.E., Guy, A.W., Hjeresen, D.L. and Hinds, W.T. 1978. Compilation and Assessment of Microwave Bioeffects. DOE Report PNL -2634 .

LaRiviere, M.G., Scott, A.J., Woodfield, W.G., and Cushing, C.E. 1978. A Bibliography on Cycling of Trace Metals in Freshwater Ecosystems. DOE Report PNL-2706.

Lee, J., Brackenbud, T.D., and Rogers, L.E. 1978. Electric and magnetic fields as considerations in environmental studies of transmission lines. In: Biological Effects of Extremely Low-Frequency Electromagnetic Fields. 18th Annual Hanford Life Science Symposium. Battelle, Richland, WA, in press.

Lee, R.F., Gardner, W.S., Anderson, J.W., Blaylock, J.W., and Barwell-Clarke, J. 1978. Fate of polycyclic aromatic hydrocarbons in controlled ecosystem enclosures. Environ. Sci. and Tech. $12: 832-838$.

Lund, J.E., and Abernethy, C.S. 1978. Lesions of tuberculosis in mountain whitefish (Prosopium williamsoni). J. Wildlife Diseases 14: $222-228$.

McCullough, D.A., Minshall, G.W., and Cushing, C.E. 1978. Bioenergetics of a stream "collector" organism, Tricorythodes minutus (Insecta: Ephemeroptera), Limnology and 0ceanography, accepted.

McCullough, D.A., Minshall, G.W., and Cushing, C.E. 1978. Bioenergetics of lotic filter-feeding insects Simulium spp. (Diptera) and Hydropsyche occidentalis (Trichoptera) and their function in controlling organic transport in streams. Ecology, accepted. 
Mckenzie, D.H., and Thomas, J.M. 1973. Towards improved field experimental designs and quantitative evaluation of aquatic ecosystem, ms. prepared.

Moeller, J.R., Minshall, G.W., Cummins, K.W., Petersen, R.C., Cushing, C.E., Sede1l, J.R., Larson, R.A., and Vannote, R.L. 1978. Transport of dissolved organic carbon in streams of differing physiographic characteristics. Organic Chemistry, submitted.

Montgomery, J.C., and Fickeisen, D.H. 1978. Buoyancy of aquatic insect larvae exposed to gas supersaturated water, submitted.

Montgomery, J.C., and Fickeisen, D.H. 1978. Spawning and movements of smallmouth bass (Micropterus dolomieui) in the mid-Columbia river. DOE Report PNL-2785.

Neitzel, D.A., and Page, T.L. 1978. Multiple bottle holder for in situ measurement of primary productivity. Progressive Fish-Culturist, accepted.

Nicholson, P.R., Thomas, J.M., and Watson, C.R. 1978. Evaluation of RT-11 pseudo random number generator. In: Proceedings of 1978 Fall DECUS Symposium. San Francisco, CA, November 27-30.

Page, T.L. Neitzel, D.A., and Gray, R.H. 1978. Comparative fish impingement at two adjacent intakes. In: Proceedings of the Fourth National Workshop on Impingement and Entrainment, ed. L. J. Jensen, pp 258-266. Ecological Analysts Communications, Melville, NY.

Perrigo, L.D., Gray, R.H., Jensen, G.A., Laity, W.W., and Moles, R.G. 1978. An overview of the OTEC biofouling and corrosion program. In: Proceedings of the Ocean Thermal Energy Conversion (OTEC) Biofouling and Corrosion Symposium, ed. R.H. Gray, DOE Report CONF-771001.

Rickard, W.H. 1978. Terrestrial ecology assessment In: The Hanford Nuclear Energy Center - A Conceptual Study, ed. H. Harty, pp. 85-94. DOE Report PNL-2640.

Rickard, W.H., and Fitzner, R.E. 1978. Avifaunal survey of the Trojan nuclear power station, Oregon. Northwest Sci. 52(1):61-66.

Rickard, W.H., Hedlund, J.D., and Schreckhise, R.G. 1978. Rejecta cast from heron nests as a indicator of environmental contamination. Auk 95(2):525-427.

Rickard, W.H., Klepper, E.L., Sauer, R.H., and Thorp, J.M. 1978. Balsamorhiza rosea and Eriogonum thymoides in Benton County, Washington, 1978. Northwest Sci. $52(2): 110-118$.
Riley, R.G., and Bean, R.M. 1978.

Application of liquid and gas

chromatographic techniques to a study of the persistence of petroleum in marine sediments. In: Proceedings of the 9th

Materials Research Symposium on Trace Organic Analysis. National Bureau of Standards, Washington, DC.

Robertson, D.E. 1978. Neutron activation techniques for determination of $\mathrm{Cu}, \mathrm{Zn}, \mathrm{Ag}$ and $A s$ in the Altantic Ocean. Trans. Amer. Nuc 1. Soc. 27:170-172.

Roesijadi, G. 1978. Taurine and glycine in the gills of the clam Protothaca staminea exposed to chlorinated seawater. Bull. Environ. Contam. and Toxicol., accepted.

Roesijadi, G. 1978. Water turnover rates in the megalopa and crab stages I to $V$ of Pinnixa occidentalis. Comparative Biochemistry and Phys iology, 59A:259-260.

Roesijadi, G., Anderson, J.W. 1978.

Condition index and free amino acid content of Macoma inquinata exposed to oil-contaminated marine sediments. In: Proceedings of Pollution and Physiology of Marine Organisms Symposium, Georgetown, SC, Nov. 14-17, 1977. Academic Press, NY.

Roesijadi, G., Anderson, J.W., and Blaylock, J.W. 1978. Uptake of hydrocarbons from marine sediments contaminated with Prudhoe Bay crude oil: Influence of feeding type of test species and availability of polycyclic aromatic hydrocarbons. J. Fish. Res. Board Can. 35:608:614.

Roesijadi, G., Jacobsen, D.M., Bridge, J.R., and Crecelius, E.A. Distribution of magnesium regulation in the crab Cancer products exposed to chlorinated seawater. (PNL-SA-6959) In: Marine Environmental Research, accepted.

Roesijadi, G., Jacobsen, D.M., Bridge, J.R., and Crecelius, E.A. 1978, Distribution of magnesium regulation in the crab Cancer productus exposed to chlorinated seawater. Marine Environmental Research, in press.

Roesijadi, G., Woodruff, D.L., and Anderson, 3.W. 1978. Bioavailability of naphthalenes from marine sediments artificially contaminated with Prudhoe Bay crude oil. Environmental Pollution 15:?23.

Rogers, L.E. 1978. Analysis of invertebrate populations inhabiting the shrub-steppe region of southcentral Washington (Hanford Reservation). In: National Environmental Research Park Symposium: Natural Resource Inventory, Characterization, and Analysis, ed. J. T. Kitchings and N. E. Tarr, pp. 83-93. DOE Report ORNL-5304. 
Rogers, L.E. 1978. Analysis of invertebrate populations inhabiting the shrub-steppe region of southcentral Washington (Hanford Reservation). Northwest Sci., submitted.

Rogers, L.E. 1978. Shrub Inhabiting Insects of the 200 Area Plateau. DOE Report PNL-2713.

Rogers, L.E., Gilbert, R.0., Lee, J.M., and Brachen, T.D. 1978. BPA $1200 \mathrm{KV}$ transmission line project--environmental studies. In: IEEE Trans. On Power Apparatus System, in press.

Rogers, L.E., and Hedlund, J.D. 1978. A comparison of small mammal populations occupying three distinct shrub-steppe communities in eastern Oregon. Northwest Sci., submitted.

Rogers, L.E., and Woodley, N.E. 1978. Invertebrate density and biomass distribution patterns in an old-field community in south-central Washington. Northwest Sci. 52(2): 100-103.

Rogers, L.E., Woodley, N., Sheldon, J.K., and Uresk, V.A. 1978. Darkling Beetle Populations (Tenebrionidae) of the Hanford Site in Southcentral Washington, DOE Report PNL -2465 .

Rossi, S.S., and Anderson, J.W. 1978. Effects of No. 2 fuel oil water-soluble fractions on growth and reproduction in Neanthes arenaceodentata (Polychaeta: Annelida). Water, Air and Soil Pollution 9:155-170.

Rossi, S.S., and Anderson, J.W. 1978. Petroleum hydrocarbon resistance in the marine worm Neanthes arenaceodentata (Polychaeta: Annelida) induced by chronic exposure to No. 2 fuel oil. Bu11. Env. Contam. and Toxicol., in press.

Routson, R.C., and Brown, D.J. 1978. Frontal movement of aqueous solutions during redistribution through air-dry sand columns as a function of column length and time. Soil Sci. 125:13-18.

Routson, R.C., and Cataldo, D.A. 1978. Accumulation of Tc by tumbleweeds and cheatgrass grown on arid soils. Health Phys. $34: 685-690$.

Routson, R.C., and Cataldo, D.A. 1978. A growth chamber study of the effect of soil concentration and plant age on the uptake of $\mathrm{Sr}$ and $\mathrm{CS}$ by tumbleweeds. Commun. Soil Sci. and Plant Anal. 9(3):215-22.
Routson, R.C., Wildung, R.E., and Bean, R.M. 1973. A review of the environmental impact of ground disposal of oil shale wastes. 3 . Environ. Qual., in press.

Sauer, R.H. 1978. Effect of removal of standing dead material on growth of Agropyron spicatum. 3. Range Management 31(2):121-122.

Sauer, R.H. 1978. A simulation model for grassland primary producer phenology and biomass dynamics. Ecological Studies $26: 55-87$.

Sauer, R.H. 1978. Precipitation, harvesting and restoration on strip mine spoils. J. Range Manage., in press.

Sauer, R.H. 1978. Precipitation, harvesting and restoration on strip mine spoils. In: Proceedings of the International Conference on Energy and Ecosystems, Grand Forks, ND, June $12-16$.

Sauer, R.H., and Rickard, W.H. 1978. Vegetation of steep slopes in the shrub-steppe region of southcentra? Washington. Northwest Sci., accepted.

Schmidt, R.L. 1978. Copper in the marine environment, Part I. In: Critical Reviews of Environmental Control Technology. CRC Press, August.

Schmidt, R.L. 1978. Copper in the marine environment, Part II. In: Critical Reviews of Environmental Control Technology. CRC Press, September.

Schmidt, R.L., Wildung, R.E., and Garland, T.R. 1978. Characterization of soluble copper species in estuarine sediments. In: Environmental Chemistry and Cycling Processes, ed. D. C. Adriano and I. L. Brisbin, Jr., DOE Symposium Series No. 45. CONF-760429.

Schneider, M.J., Connors, T.J., Genoway, R.G., and Barraclough, S.A. 1978. Effects of water temperature of exercise on $\mathrm{fish}$ energy physiology. Northwest Sci., submitted.

Schneider, M.J., Genoway, R.G., Connors, T.J., and Barraclough, S.A. 1978. A device for serial, nontraumatic sampling of fish stocks in physiological studies. Prog. Fish-Culturist, accepted.

Schreckhise, R.G. 1978. Long-Term Accumulation of Radiocontaminants in Crop Plants, DOE Report PNL-2636, in preparation. 
Schreckhise, R.G., and Cline, J.F. 1978. Comparative uptake and distribution of $\mathrm{Pu}$, $\mathrm{Am}, \mathrm{Cm}$ and $\mathrm{Np}$ in four plant species. Health Phys, submitted.

Schreckhise, R.G., and Cline, J.F. 1978. Comparative uptake and distribution of $P u$, Am, $\mathrm{Cm}$ and $\mathrm{Np}$ in four plant species. I $\mathrm{r}$ : Transuranic Elements in the Environment, ed. W. C. Hanson, TID-22800, in press.

Schreckhise, R.G., and Cline, J.F. 1978. Uptake and distribution of $\mathrm{Pu}, \mathrm{Am}, \mathrm{Cm}$ and $\mathrm{Np}$ in four plant species. In: Abstracts of papers presented to the Health Physics Society 1978 Annual Meeting, Minneapolis, MN, Pergamon Press, NY.

Schreckhise, R.G., and Cline, J.F. 1978. Uptake of 232-U by peas and barley. In: Abstracts of Papers presented to the Health Physics Society 1978 Annual Meeting, Minneapolis, MN, Pergamon Press, NY.

Sheldon, J.K., and Rogers, L.E. 1978. Grasshopper food habits within a shrub-steppe community. Oecologia 32:85-92.

Silviera, D.J., Garland, T.R., and Wildung, R.E. 1978. Characterization of retorted oil shale leachate in laboratory studies. In: Agronomy Abstracts, ASA, SSSA and CSSA Annual Meetings, Chicago, IL, December 3-8.

Siniff, D.B., Stirling, I., and Eberhardt, L.L. 1978. Problems in the conservation of polar marine mammals. Ch. 7 In: Polar Research, ed. M. A. McWhinnie, AAAS Selected Symposium Volume, Amer. Assoc. for Advancement of Science.

Sommers, L.E., Wildung, R.E., and Gilmour, C.M. 1978. The effects of water potential on decomposition processes in soil. In: Abstracts of the ASA, CSSA, and SSSA Annual Meetings, Chicago, IL, December 3-8.

States, J.B., Becker, C.D., Schneider, M.J., Strand, J.A. 1978. Response of aquatic biota to effluents from Fort Lewis, Washington, solvent refined coal pilot plant. In: Proceedings of Symposium on Potential Health and Environmental Effects of Synthetic Fossil Fuel Technologies, Gatlinberg, TN, September.

Strand, J.A., Fujinara, M.P., and Poston, T.M. 1978. Permanence of suppression of the primary immune response in rainbow trout sublethally exposed to tritium during embryogenesis. In: Abstracts of Conference of Western Association of State Game and Fish Commissioners and Western Division American Fisheries Society.
Sullivan, M.F., Cataldo, D.A., and Schreckhise, R.G. 1978. Absorption and retention of ingested inorganic and organically bound technetium. In: Abstracts of World Federation of Nuclear Medicine and Biology, Second International Congress, Washington, DC, September 17-21, 1978.

Tatem, H.E., Cox, B.A., and Anderson, J.W. 1978. The toxicity of oils and petroleum hydrocarbons to estuarine crustaceans. Estuarine and Coastal Marine Sci. 6:365-373.

Templeton, W.L. 1978. Dosimetry and ecological effects of transuranics in the marine environment. In: Transuranic Elements in the Environment, ed. W. C. Hanson, TID-22800, in press.

Templeton, W.L. ed. 1978. Workshop on Copper in Estuarine, Cont inental and Marine Waters, DOE Report CONF-771236.

Thatcher, T.0. 1978. A morphological defect in shiner perch resulting from chronic exposure to chlorinated seawater, Bulletin Env. Cont. and Toxicol., in press.

Thatcher, T.0. 1978. The relative sensitivity of twenty Pacific Northwest. fishes and invertebrates to chlorinated seawater. In: Proceedings of Conference on Water Chlorination: Environmental Impact and Health Effects, pp. 341-350, GatTinburg, TN, 1977 .

Thomas, J.M. 1978. A qualitative/ quantitative procedure for assessing the biological effects of waste heat on economically important populations. In: Proceedings of the Second Waste Heat Management Conference, Miami Beach, FL, December 4-6.

Thomas, J.M., and Bair, W.J. 1978. Risk projections from experimental animal data on carcinogenic effects of inhaled

radionuclides--who should make projections. In: Proceedings of papers presented to the Annual Meeting, American Statistical Association, San Diego, CA, August 14-17.

Thomas, J.M., and Eberhardt, L.L. 1978. From mouse to man - an extrapolation of radionuclide retention data. Nature, submitted.

Thomas, J.M., Eberhardt, L.L., and Hanson, W.C. 1978. Evaluating the compatibility of simulation models and data, prepared.

Thomas, J.M., Mahaffey, J.A., Gore, K.L., and Watson, D.G. 1978. Statistical methods used to assess biological impact at nuclear power plants. J. Environ. Manage. 7. 
Thomas, J.M., and Mckenzie, D.H. 1978. A proposal for assessing biological effects of power plants on fish populations, submitted.

Uresk, D.W. 1973. Diet of the blacktailed hare in steppe vegetation. J. Range

Manage., in press.

Uresk, D.W., Cline, J.F., and Rickard, W.H. 1978. Growth rates of a cheatgrass community and some associated factors. J. Range Manage., in press.

Uresk, D.W., and Uresk, V.A. 1978, Diets and Habitat Analysis of Mule Deer on the 200 Area of the Hanford Reservation in South Central Washington, DOE Report PNL-2467.

Vanderhorst, J.R., and Wilkinson, P. 1978. Clam resource measurement for estimation of pollution damage. In: Proceedings of the 1977 Meeting of the Pacific Coast Section of the National Shellfisheries Association, Tumwater, WA, September 9-10, 1377.

Vanderhorst, J.R., and Wilkinson, P. 1973. Evaluation of marine invertebrate species diversity as an oil toxicity indicator from laboratory studies. In: Proceedings of the 4th Annual Toxicity Conference, Environment Canada Technical Report Series.

Vanderhorst, J.R., and Wilkinson, P. 1978. The littleneck clam (Protothaca staminea) as a tool for potential oil pollution assessment: Density of stock. PNL-SA-6639, Pacific Northwest Laboratory, Richland, WA.

Warner, M.L., Becker, C.D., Hinds, W.T., and Sauer, R.H. 1978. Impacts on ecosystems. In: The Impact of Increase Coal Consumption in the Pacific Northwest, pp. 8.1-8.2?, National Coal Utilization Assessment, DOE Report BNWL-RAP-21.

Watson, C.R., Cochran, M.I., Thomas, J.M., and Eberhardt, L.L. 1978. COMP-A BASIC nonlinear least squares curve fitting package. In: Proceedings of the Digital Equipment Computer Users Society, pp 515-519, San Diego, CA.

Weimer, W.C., and Langford, J.C. 1978. Iron-55 and stable iron in oceanic aerosols: forms and availability. Atmospheric Enviroriment 12(5):1201.

White, G.C., and Gilbert, R.0. 1978. TRAN-STAT: Statistics for environmental transuranic studies. PNL-SA-7061, Pacific Northwest Laboratory, Richland, WA.
Wildung, R.E., and Cataldo, D.A. 1978. Soil and plant factors influencing the accumulation of heavy metals by plants. Environmental Health Perspectives, in press.

Wildung, R.E., and Garland, T.R. 1978. Environmental processes leading to the presence of organically bound plutonium in plant tissues consumed by animals. Submitted to the International Symposium on Biological Implications of Radionuclides Released from Nuclear Industries. IAEA. Vienna, Austria, March 26-30, 1979.

Wildung, R.E., Garland, T.R., and Drucker, H. 1978. Nickel complexes with microbial metabolites-mobility and speciation in soils. In: Proceedings of Symposium on Chemical Modeling - Speciation, Sorption, Solubility and Kinetics in Aqueous Systems, ed. E. A. Jenne, American Chemical Society, Washington, DC.

Wildung, R.E., MCF adden, K.M., and Garland, T.R. Technetium sources and behavior in the environment, J. Envir. Qual., accepted.

Wogman, N.A., and Nielson, K.K. 1978. Development and application of an in situ $x-r$ ay fluorescence spectrometer for underwater sediment analysis. Accepted for the ACS Symposium, Recent Advances in Nuclear Analytical Methods, Honolulu, HA, Apri1 2-6, 1979.

Young, J.S. 1978. Metal injury to transport epithelia in aquatic animals. In: Proceedings of Workshop on Copper in Estuarine, Continental and Marine Waters, abstract, p. 28, CONF-771236.

Young, J.S., Apts, C.W., Gibson, C.I., Joyce, S.P., and Lloyd, B.M. 1978. Effects of copper on the coon stripe shrimp, Pandlua danae. Marine Biology, in press.

Young, J.S., Buschbom, R.I., Gurtisen, J.M., and Joyce, S.P. 1978. Effects of copper on the sabellid polychaete, Eudistylia vancouveri. I. Concentration limits for copper accumulation. In: Archives of Environmental Contamination and Toxicology, in press.

Young, J.S., Gurtisen, J.M., Apts, C.W., and Crecelius, E.A. 1978. The relationship between the copper complexing capacity of sea water and copper toxicity in shrimp zoeae. Marine Environmental Research, in press. 


\section{PRESENTATIONS}

Apts, C.W., Crecelius, E.A., Philbrick, C.W., Schmidt, R.L., and Young, J.S. The availability of copper to the detrital feeding clam, Macoma inquinata. Paper presented at

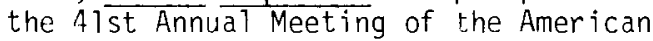
Society of Limnology and Oceanography, Victoria, BC, June 19-22, 1978.

Anderson, D.R. 1978. Effects of chlorination byproducts on rainbow trout (Salmo gairdner $i$ ). Presented to the Pacific Northwest Pollution Control Association, Victoria, BC, October, 1978.

Bean, R.M., Blaylock, J.W. and Riley, R.G. Application of trace analytical techniques to a study of changes in hydrocarbon composition upon dispersion of petroleum in a flowing seawater system. Paper presented at the 96th Materials Research Symposium, Gaithersburg, MD, Apri1 10-13, 1978.

Bean, R.M., Blaylock, J.W. and Riley, R.G. Application of trace analytical techniques of hydrocarbon composition upon dispersion of petroleum in a flowing seawater system. Paper presented at the Symposium on Analytical Chemistry of Petroleum Hydrocarbons in the Marine/Aquatic Environment, Division of Petroleum Chemistry, Inc., Miami Beach, FL, September 10-15, 1978.

Cataldo, D.A., Riley, R.G., and Fallon, W.E. Physiological effects of oil shale water on plants. Paper presented at the ASA, CSSA and SSSA Annual Meetings, Chicago, I', December 3-8, 1978.

Cline, J.F., and Holter, G.M. The effect of soil affixants on germination, emergence and growth of cheatgrass and Russian thistle. Paper presented at the 1978 Meeting of the Society for Range Management, San Antonio, TX, February 1978.

Crecelius, E.A. Deposition rate of airborne particulate elements on the Washington coast. Paper presented at the ASLO meeting, Victoria, Canada, June 12-22, 1978.

Cushing, C.E. Physical-chemical cluster analysis of streams. Paper presented at the Symposium of the Ecological Society of America, Athens, GA, August 24, 1978.

Doctor, P.G., and Gilbert, R.0. Two studies in variability for soil concentration: with aliquot size and with distance. Paper presented at the NAEG Plutonium (and other Transuranics) Information Conference, San Diego, CA, February, 1978.
Drucker, H., Garland, T.R. and Wildung, R.E. Bacterial genera, metal resistance and metal modification. Paper presented to the American Society of Microbiology, Las Vegas, NV, May 14-18, 1978.

Eberhardt, 1.... Determining 'optimal' levels for marine mammals. Paper presented to the International Conference on the Population Dynamics of Large Mammals, Logan, UT, May 25-27, 1978.

Eberhardt, L.L. Development in line transect methodology. Paper presented at a seminar, University of Washington, Seattle, WA, March 1978.

Fitzner, R.E. Management of burrowing owls in western rangelands. Paper presented to the 1978 Meeting of the Society for Range Management, San Antonio, TX, February 1978.

Garland, T.R., Wildung, R.E., and Harbert, H.P. Mobility of macro-ions, trace elements and organic components after application of irrigation water to lysimeters containing retorted oil shale. Paper presented at the ASA, CSSA, SSSA Annual Meetings, Chicago, IL, December 3-8, 1978.

Gilbert, R.0., and Eberhardt, L.I. Statistics in NAEG soil studies: current status and review of past offorts. Paper presented at the NAEG Plutonium (and other Transuranics) Information Conference, San Diego, CA, February 1978.

Gray, R.H. Microfouling in subtropical ocean thermal energy conversion units. Paper presented at the ACS Colloid and Surface Science Symposium, Knoxville, TN, June 12-14, 1978.

Haynes, J.M, Gray, R.H., and Montgomery, J.C. Seasonal and diurnal movements of radio-tagged white sturgeon (Acipenser transmontanus) in relation to mid-Columbia river temperatures. Paper presented to American Fisheries Society, 108th Annual Meeting, University of Rhode Island, Kingston, August 21-25, 1978.

Hinds, W.T. Research areas in the sagebrush. Paper presented to the 1978 Meeting of the Society for Range Management, San Antonio, TX, February 1978. 
Li, S.W., and Rogers, I.E. The bacterial and fungal degradation of organic residuals in oil shale retort waters. Paper presented at the ASA, CSSA, SSSA Annual Meetings, Chicago, IL, December 3-8, 1978.

Nicholson, P.R., Thomas, J.M., and Watson, C.R. Evaluation of RT-11 pseudo-random number generator. Paper presented at the 1978 Fa11 DECUS Symposium, San Francisco, CA, November 27-30, 1978.

Page, T.L., and Gray, R.H. Recommendations and comprehensive program plan for gas bubole disease research in Italy. Paper presented at Ente Nazionale per l'Energia Electtrica, Center for Nuclear and Thermal Research, Milan, Italy, January 1978.

Rickard, W.H. Drought in the shrub steppe region of Washington - 1977. Presented to the Second International Botanical Congress, Tel Aviv, Israe1, September 6, 1973.

Rickard, W.H., Fitzner, R.E., and Sauer, R.H. Canada goose, coyote and man in a rapidly changing region environment. Paper presented at the Northwest Scientific Association, Pullman, WA, March 31, 1978.

Rickard, W.H., and Hinds, W.T. The National Environmental Research Park at Hanford. Paper presented at meeting of the Ecological Society of America, University of Georgia, Athens, August 1978.

Riley, R.G., and Bean, R.M. Application of liquid and gas chromatographic techniques to a study of the persistence of petroleum in marine sediments. Paper presented at the National Bureau of Standards, 9th Materials Research Symposium, Trace Organic Analysis: A New Frontier in Analytical Chemistry, Gaithersburg, MD, April 10-13, 1978.

Rogers, J.E., and Li, S.W. Microbiological aspects of the ground disposal of oil shale wastes. Paper presented to the American Society of Microbiology, Northwest Regional Meeting, Vancouver, BC, June 30, 1978.

Rogers, J.E., and Li, S.W. The microbial colonization of retorted oil shale under field and laboratory conditions. Paper presented at the ASA, CSSA, SSSA Annual Meetings, Chicago, IL, December 3-8, 1978.

Sauer, H.R. Precipitation, harvesting and restoration on strip mine spoils. Paper presented to the International Conference on Energy and Ecosystems, Grand Forks, ND, June 12-16, 1978.
Schmidt, R.L.., and Gibson, C.T. The influence of organic matter on trace metal flux in coastal sediments. Paper presented at the 4 lst Annual Meeting of the American Society of Limnology and Oceanography, Victoria, BC, June 19-22, 1978.

Schreckhise, R.G., and Cline, J.F. Uptake and distribution of $\mathrm{Pu}, \mathrm{Am}, \mathrm{Cm}$ and $\mathrm{Np}$ in four plant species. Paper presented to the Health Physics Society 1978 Annual Meeting, Minneapolis, MN, June 18-23, 1973.

Schreckhise, R.G., and Cline, J.F. Uptake of U-232 by peas and barley. Paper presented to the Health Physios Society 1978 Annual Meeting, Minneapolis, MN, June 18-23, 1978.

Silviera, D.J., Garland, T.R., and Wildung, R.E. Characterization of retorted oil shale leachate in field and laboratory studies. Paper presented at the ASA, CSSA and SSSA Annual Meetings, Chicago, [1-, December 3-8, 1978.

Sullivan, M.F., Cataldo, D.A., and Schreckhise, R.G. Absorption and retention of ingested inorganic and organically bound technetium. Paper presented to the World Federation of Nuclear Medicine and Biology, Second International congress, Washington, DC, September 17-21, 1978.

Thomas, J.M. A qualitative/quantitative procedure for assessing the biological effects of waste heat on economically important populations. Paper presented at the 2nd Waste Heat Management and Utilization Conference, Miami Beach, FL, December 4-6, 1978.

Thomas, J.M., and Bair, W.J. A review and analysis of experimental animal data on carcinogenic effects of inhaled aipha and intratracheally instilled beta-gamma emitting radionuclides. Paper presented at the International Symposium on the Late Biological Effects of Ionizing Radiation, Vienna, Austria, March 13-17, 1978.

Thomas, J.M., and Bair, W..1. Risk projections from experimental animal data on carcinogenic effects of inhaled radionuclides - who should make projections. Paper presented to the Annual Meeting, American Statistical Association, San Diego, CA, August 14-17, 1978.

Uresk, D.W., Rickard, W.H., and Cline, J.F. Response of shrub-steppe vegetation after wildfire. Paper presented at the 1978 Meeting of the Society for Range Management, San Antonio, TX, February 1978. 
Uresk, D.W., Rickard, W.H., and Cline, J.F. Response of three perennial grasses after wildfire in southcentral Washington. Paper presented at the Annual Meeting of the AAAS and the Society of American Foresters, Seatt le, WA, June 1978.

Uresk, D.W., and Uresk, V.A. Diets of mule deer within steppe vegetation of southcentral Washington. Paper presented at the 1978 Meeting of the Society for Range Management, San Antonio, TX, February 1978.

Vanderhorst, J.R., Anderson, J.W., Wilkinson, P., and Woodruff, D.L. Estimation of effects from oil on intertidal populations: Experimental perturbation versus natural variation. Paper presented to Conference on Assessment of Ecological Impacts of 0 il Spills, Keystone, C0, June 14-17, 1978.

Wildung, R.E. Significance of environmental pathways in pollutant toxicology. Paper presented to the Intra-Science Symposium on Trace Metals in Health and Disease, Santa Monica, CA, November 29, 1978.
Wildung, R.E., and Cataldo, D.A. Soil and plant factors influencing the accuntulation of heavy metals by plants. Paper presented to NIEHS Workshop, Higher Plant Systems as Monitors of Environmental Mutagens, Marineland, FL, January 15-18, 1978.

Wildung, R.E., Garland, T.R., and Drucker, H. Nickel complexes with microbial metabolites mobility and speciation in soils. Paper presented at ACS Symposium on Chemical Modeling--Speciation, Sorption, Solubility and Kinetics in Aqueous Systems, Miami, FL, September 1978 .

Young, J.S. Influence of the copper complexing capacity of seawater on copper toxicity in zoeae of the coon stripe shrimp, Pandalus danae. Paper presented at the Meeting of the Pacific Estuarine Research Society, Seattle, WA, April 1978. 

Index of

Investigators 


\section{INDEX OF INVESTIGATORS}

Abel, K. H.; 9.17

Anderson, D. R.; 9.7, 11.3

Anderson, J. W.; 4.5, 11.12

Apts, C. W.; 9.13

Baker, K. S.; 1.3, 11.6

Barraclough, S. A.; 3.3

Bean, R. M.; 2.3, 11.3

Becker, C. D.; 1.3, 3.3, 7.3, 11.11

Cadwell, L. L.; 5.13, 5.17, 10.3

Cataldo, D. A.; 2.3, 5.3, 5.25, 10.3

Cline, J. F.; 5.13, 5.17, 10.3, 10.11

Cochran, D. A.; 9.17

Crecelius, E. A.; 9.13, 9.17, 9.23

Cushing, C. E.; 1.3, 11.11

Davis, K. C.; 6.3

Doctor, P. G.; 5.7

Eberhardt, L. L.; 5.7, 9.3

Emery, R. M.; 5.17, 6.3

Fallon, W. E.; 2.3

Fickeisen, D. H.; 7.3, 11.6

Fitzner, R. E.; 5.17, 10.3, 10.11

Fox, K.; 8.3

Fujihara, M. P.; 6.3

Gano, K. A.; 5.17, 10.3, 10.11

Garland, T. R.; 2.3, 5.3, 5.25

Genoway, R. G.; 3.3

Gibson, C. I.; 9.13, 11.3

Gilbert, R. O.; 5.7

Gore, K. L.; 11.6, 11.11

Gray, R. H.; 7.3

Gurtisen, J. M.; 9.13

Hinds, W. T.; 1.3

Kannburg, L. D.; 9.13

Kutt, J.; 5.9

Laul, J. C.; 5.9

Li, S. W.; 2.3

Mann, D. C.; 11.3

McFadden, K. M.; 2.3, 5.3, 5.25
McKenzie, D. H.; .1.3, 11.6

McNair, V. N.; 2.3

Montgomery, J. C.; 6.3, 7.3

Neil, L. C.; 2.3

Nielson, K. K.; 9.17

Philbrick, C. W.; 9.17

Poston, T. M.; 3.3, 5.17, 6.3

Rancitelli, L. A.; 9.17

Rickard, W. H.; 1.3, 5.17, 10.11, 10.13

Riley, R. G.; 2.3, 11.3

Roesijadi, G.; 9.10

Robertson, D. E.; 9.17

Rogers, J. E.; 2.3, 5.3, 9.13

Rogers, L. E.; 1.9, 5.17, 8.3, 10.3, 10.11, 11.7

Sauer, R. H.; 1.9

Schmidt, R. L.; 9.13

Schneider, M. J.; 3.3, 9.7

Schreckhise, R. G.; 5.13, 5.17

Scott, A. J.; 3.3

Shiosaki, K.; 2.3

Shirmer, R. E.; 11.3

Skalski, J. R.; 11.6

Silviera, D. J.; 2.3

States, J. B.; 3.3

Strand, J. A.; 3.3, 6.3

Sullivan, M. F.; 5.3

Templeton, W. L.; 9.23

Thomas, J. M.; 9.3

Uresk, D. W.; 10.3

Vanderhorst, J. R.; 4.3

Warner, M. L.; 8.3, 11.11

Watson, D. G.; 10.13

Weimer, W. C.; 5.9

Wildung, R. E.; 5.3, 5.25, 10.3, 11.13

Wilkerson, C. L.; 9.17

Wogman, N. A.; 9.17

Young, J. S.; 9.10 

Organization Charts

Distribution 


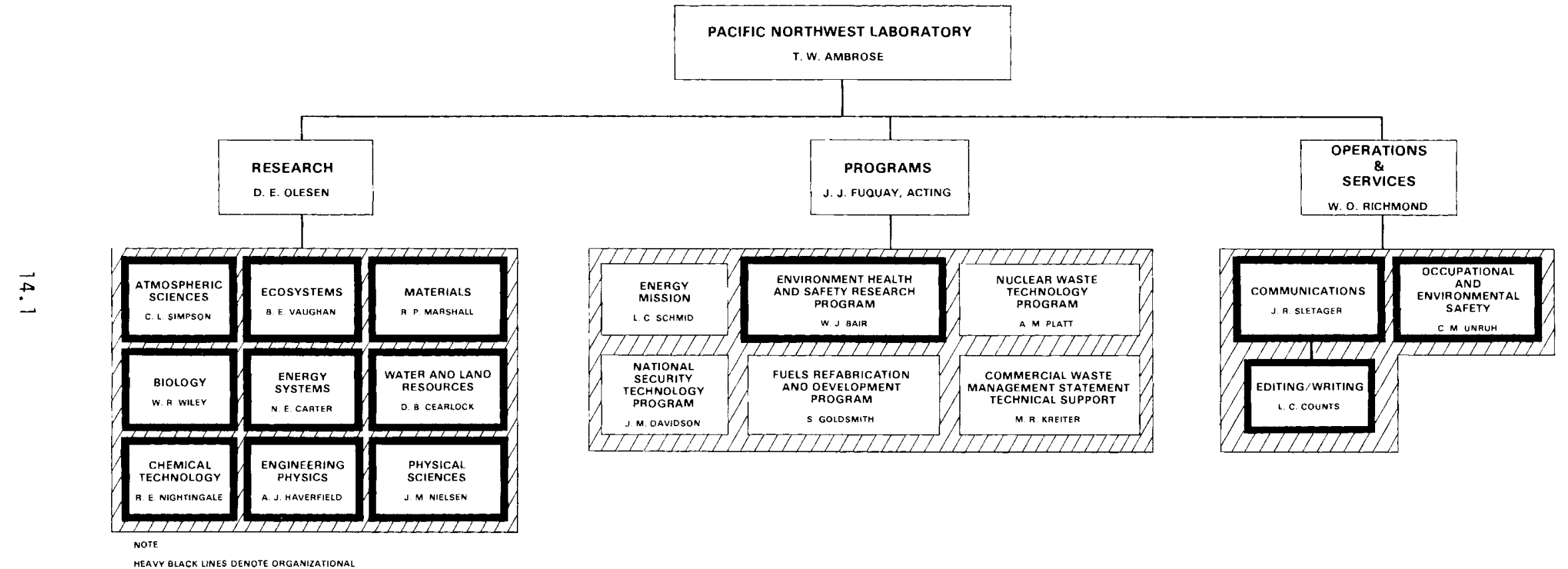

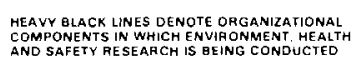




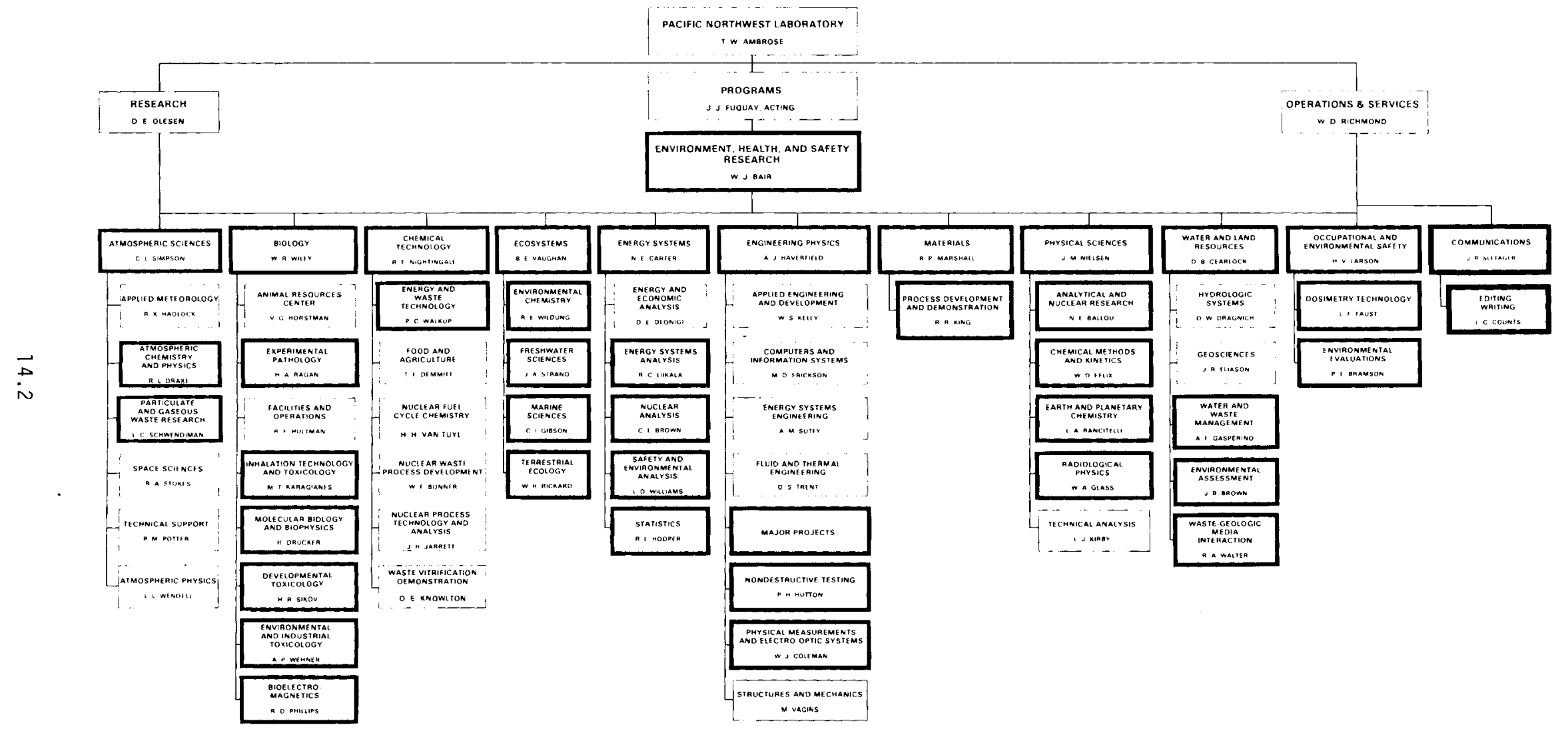

arer 


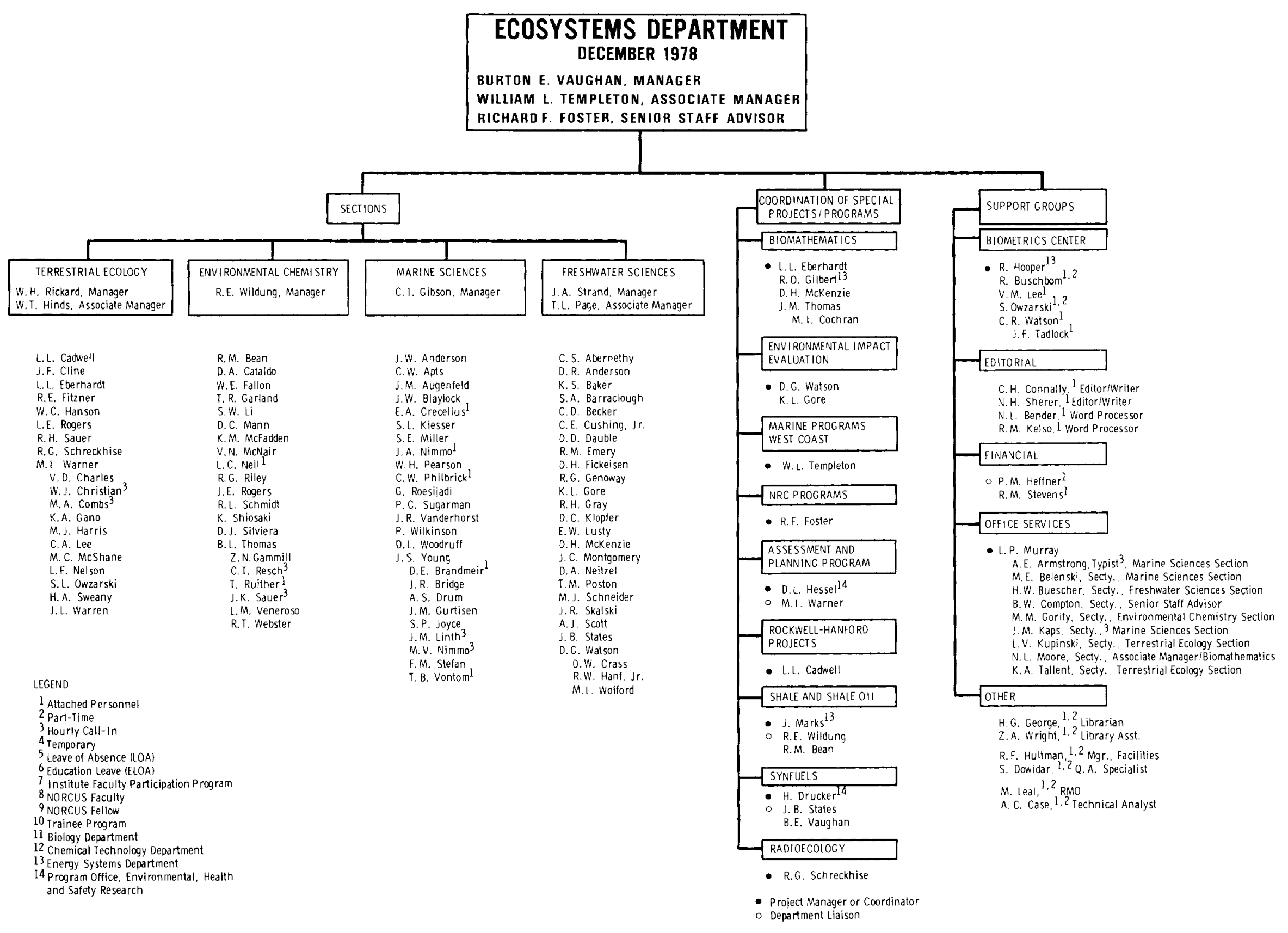




\section{OTHER CONTRIBUTORS}

Physical Sciences Department

Abel, K. H.

Cochran, D. A.

Kutt, J.

Laul, J. C.

Nielson, K. K.

Rancitelli, L. A.

Robertson, D. E.

Weimer, W. C.

Wilkerson, C. L.

Wogman, N. A.

\section{Projects}

Fox, $\mathrm{K}$.

\section{Biology Department}

Fujihara, M. P.

Neil, L. C.

Shirmer, R. E.

Sullivan, M. F.

Energy Systems Department

Doctor, P. G.

Gilbert, R. O.

Water and Land Resources Department

Kannburg, L. D.

Atmospheric Sciences

Davis, K. C. 


\section{DISTRIBUTION}

\section{OFFSITE}

\section{Patent Office}

A. A. Churm

DOE Chicago Patent Group

9800 South Cass Avenue

Argonne, IL 50439

Department of Energy

W. R. Albers

Chief, Occupational Medical

Branch

Division of Safety

Engineering

DOE

Washington, DC 20545

D. S. Ballantine

Office of Health and

Environmental Research

$\mathrm{DOE}$

Washington, DC 20545

R. W. Barber, Acting Director Division of Safety Engineering DOE

Washington, DC 20545

N. F. Barr

Office of Health and

Environmental Research

DOE

Washington, DC 20545

E. W. Bean

Rocky Flats Area Office

Albuquerque Operations office DOE

P.0. Box 928

Golden, C0 80401

M. A. Bell

Chief, Reactor Safety Branch

Division of Safety

Engineering

DOE

Washington, DC 20545

J. W. Benson

Office of the Assistant

Secretary for Environment

DOE

Washington, DC 20545
L. C. Brazley

Division of NEPA Affairs

DOE

Washington, DC 20545

W. A. Brobst, Chief

Division of Environmental

Control Technology,

Transportation Branch

DOE

Washington, DC 20545

W. W. Burr, Jr., Director

Office of Health and

Environmental Research

DOE

Washington, DC 20545

C. E. Carter, Director

Division of Environmental

Research

Office of Health and

Environmental Research

DOE

Washington, DC 20545

R. J. Catlin, Acting Director

Office of Environmental

Compliance and Overview

DOE

Washington, DC 20545

R. C. Clusen

Assistant Secretary for

Environment

DOE

Washington, DC 20545

J. A. Coleman

Office of Technology Impact

DOE

Washington, DC 20545

R. A. Conaway

Division of Financial Services

DOE

Washington, DC 20545

W. Cool

Nuclear Regulatory Commission

Washington, DC 20545

D. K. Craig

Office of the Assistant

Secretary for Environment

$\mathrm{DOE}$

Washington, DC 20545
C. B. Curtis

Office of the Assistant

Secretary for Federal Energy

Regulatory Commission

DOE

Washington, DC 20545

R. L. Darneal

Office of Health and

Environmental Research

DOE

Washington, DC 20545

L. J. Deal

Assistant Director for Health

Protection

DOE

Washington, DC 20545

A. W. Decora

Laramie Energy Research Center

DOE

P.0. Box 3395

University Station

Laramie, WY 83071

J. M. Deutch (3)

Office of the Assistant

Secretary for Energy Research DOE

Washington, DC 20545

G. P. Dix, Asst. Director

Systems and Programs

Division of Operational and

Environmental Safety

DOE E-201

Washington, DC 20545

T. J. Dobry

Office of the Assistant

Secretary for Energy

Technology

DOE

Washington, DC 20545

P. B. Dunnaway

Nevada Operations Office

DOE

P.0. Box 14100

Las Vegas, NV 89114

C. W. Edington, Deputy

Director

Office of Health and

Environmental Research

DOE

Washington, DC 20545 


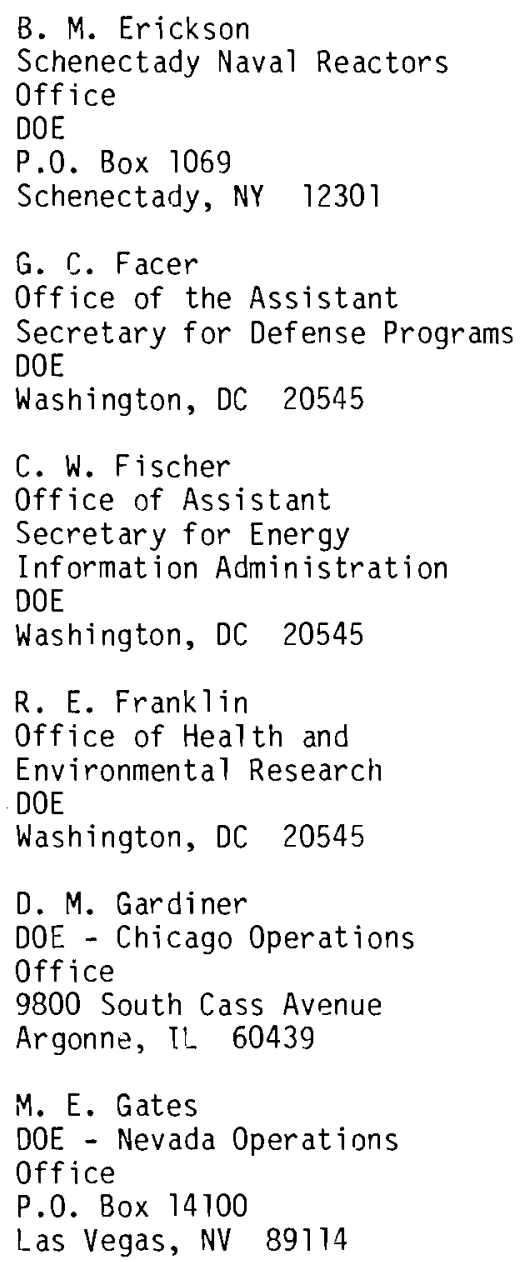

H. Gl auberman

Nuclear Programs

Division of Environmental

Control Technology

DOE

Washington, DC 20545

G. H. Gronhovd

Grand Forks Energy

Research Center

Box 8213

University Station

DOE

Grand Forks, ND 58202

T. J. Gross

Office of Health and

Environmental Research

DOE

Washington, DC 20545

R. E. Grossman

Division of NEPA Affairs

DOE

Washington, DC 20545

G. L. Hagey

Division of Environmental

Impacts

DOE

Washington, DC 20545
D. H. Hamilton

Office of Health and

Environmental Research

DOE

Washington, DC 20545

J. H. Harley

Environmental Monitoring

Laboratory

376 Hudson St.

New York, NY 10014

J. R. Haugh

Office of Health and

Environmental Research

DOE

Washington, DC 20545

J. Hock

Office of the Assistant

Secretary for Environment

DOE

Washington, DC 20545

H. L. Hollister

Scientific Advisor,

Office of Assistant Secretary

of Environment

DOE

Washington, DC 20545

P. W. House, Director Office of Technological

Impacts

DOE

Washington, DC 20545

C. Jackson

DOE - San Francisco

Operations Office

133 Broadway

Wells Fargo Building

Oakland, CA 94616

D. A. Jumes

Office of Health and

Environmental Research

DOE

Washington, DC 20545

J. S. Kane

Office of the Assistant

Secretary for Energy Research

DOE

Washington, DC 20545

J. S. Kirby-Smith

Office of Health and

Environmental Research

DOE

Washington, DC 20545

C. Kuhlman

Office of the Assistant

Secretary for Energy

Technology

DOE

Washington, DC 20545
F. A. Koomanoff

Office of the Assistant

Secretary for Energy

Technology

DOE

Washington, DC 20545

R. L. Leith

Office of the Assistant

Secretary for Environment

DOE

Washington, DC 20545

J. A. Lenhard

DOE - Oak Ridge Operations

Office

P.0. Box E

Oak Ridge, TN 37830

F. A. Leone

Division of NEPA Overview

DOE

Washington, DC 20545

W. J. Little, Jr., Director Division of Program Analysis and Evaluation

DOE

Washington, DC 20545

J. L. Liverman, Deputy

Asst. Secretary for the

Environment

DOE

Washington, DC 20545

K. E. Lockridge

Division of Program Analysis and Evaluation

DOE

Washington, DC 20545

E. K. Loop, Chief

Process \& Facilities Safety Branch

Division of Operational and

Environmental Compliance

DOE

Washington, DC 20545

W. E. Lotz

Office of the Assistant

Secretary for

Energy Technology

DOE

Washington, DC 20545

J. N. Maddox

Division of Financial

Services

DOE

Washington, DC 20545 
J. R. Maher, Acting Deputy

Director

Division of Financial Services

Division of Technology

Assessments

DOE

Washington, DC 20545

D. D. Mayhew

Office of the Assistant

Secretary for Environment

DOE

Washington, DC 20545

R. Maxwe 11

Office of Health and

Environmental Research

DOE

Washington, DC 20545

H. MCC ammon

Office of Health and

Environmental Research

DOE

Washington, DC 20545

W. J. McCool, Acting Director Division of Operational and Environmenta? Compliance DOE

Washington, DC 20545

B. F. McCully

Division of Financial

Services

DOE

Washington, DC 20545

J. Miller

Office of Health and

Environmental Research

DOE

Washington, DC 20545

M. L. Minthorn, Jr., Deputy Director

Division of Health Effects

Research

Office of Health and

Environmental Research DOE

Washington, DC 20545

D. Monti

Division of Technology

Assessment

DOE

Washington, DC 20545

W. E. Mott, Acting Director

Division of Environmental

Control Engineering

DOE

Washington, DC 20545

NRC Advisory Committee on

Reactor Safeguards

Washington, DC 20555
W. S. Osburn, Jr. Office of Health and

Environmental Research DOE

Washington, DC 20545

W. H. Pennington (3)

Division of NEPA Affairs DOE

Washington, DC 20545

A. A. Pitrolo

Morgantown Energy

Research Center

DOE

P.0. Box 880

Morgantown, WV 26505

R. W. Ramsey, Jr.

Assistant Director

Nuclear Programs

Division of Environmental

Control Engineering

DOE E-201

Washington, DC 20545

R. Ray

DOE - Nevada Operations Office P.0. Box 14100

Las Vegas, NV 89114

W. Reese

DOE - Savannah River

Operations Office

P.0. Box A

Aiken, SC 29801

J. R. Roeder

DOE - Albuquerque

Operations Office

P.0. Box 5400

Alburquerque, NM 87115

D. M. Ross

Division of Operational and

Environmental Compliance

DOE

Washington, DC 20545

G. Saunders

Office of Health and

Environmental Research DOE

Washington, DC 20545

D. E. Shaw

Office of Management

Coordination

DOE

Washington, DC 20545

G. Shepherd, Director

Office of Program

Coordination

DOE

Washington, DC 20545
N. F. Simpson

Division of Financial Services

DOE

Washington, DC 20545

R. D. Shull

Division of Environmental

Impacts

DOE

Washington, DC 20545

M. Shu Tman

Office of the Assistant

Secretary for Environment

DOE

Washington, DC 20545

D. H. Slade, Director

Division of $\mathrm{CO}_{2}$ and

Climate Research

Office of Health and

Environmental Research

DOE

Washington, DC 20545

1. Snyder

Division of Program

Analys is and Evaluation

DOE

Washington, DC 20545

H. F. Soule

Office of the Assistant

Secretary for

Energy Technology

DOE

Washington, DC 20545

J. H. Spickard

DOE - Idaho Operations

Commission

550 Second Street

Idaho Falls, ID 83401

R. J. Stern

Office of the Assistant

Secretary for Environment

DOE

Washington, DC 20545

J. F. Stevens

Dayton Area Office

DOE - Albuquerque Operations

Office

P.0. Box 66

Miamisburg, OH 45342

J. Swinebroad, Director

Division of Ecological

Research

Office of Health and

Environmental Research

DOE

Washington, DC 20545 
Technical Information Center (27)

P.0. Box 62

DOE

Oak Ridge, TN 37830

E. J. Vallario

Senior Health Physicist,

Standards Staff

Division of Safety

Engineering

DOE

Washington, DC 20545

A. R. Vincent

Division of Program

Analysis and Evaluation

DOE

Washington, DC 20545

B. W. Wachholz

Division of Policy Analysis

DOE

Washington, DC 20545

R. Watters, Leader

Nuclear Programs

Office of Health and

Environmental Research

DOE

Washington, DC 20545

S. Weinstein

Office of the Assistant

Secretary for Environment

DOE

Washington, DC 20545

I. Wender

Pittsburgh Energy

Research Center

DOE

4800 Forbes Avenue

Pittsburgh, PA 15213

W. W. Weyzen, Director

Division of

Human Health Studies Program

Office of Health and

Environmental Research

DOE

Washington, DC 20545

J. C. Whitnah, Acting Director office of Administration

Services

DOE

Washington, DC 20545

T. Williams, Director

Division of Policy Analysis

Office of Technical Impact

DOE

Washington, DC 20545
R. W. Wood, Director

Division of Pollutant

Characterization and

Safety Research

Office of Health and

Environmental Research

DOE

Washington, DC 20545

A. P. D'Zmura, Jr.

Division of Reactor

Development and Technology

Environmental Effects Branch

DOE

Washington, DC 20545

0ther Agencies and

Institutions

R. Alexander

Nuclear Regulatory Commission

Washington, DC 20545

E. L.. Alpen

Lawrence Berkeley Laboratory

University of Cal ifornia

Building 90, Room 2056

No. 1 Cyclotron Road

Berkeley, CA 94720

S. I. Auerbach

Oak Ridge National Laboratory

Oak Ridge Operations Office

PO BoX X

Oak Ridge, TN 37830

Ralph E. Austin

Biomed/Environ.

DOE

Federal/629A

Richland, WA 99352

J. A. Auxier

Oak Ridge National Laboratory

PO Box X

Oak Ridge, TN 37830

\section{J. S. Ball}

Bartlesville Energy Research

Center

DOE

PO Box 1398

Bartlesville, OK 74003

D. Beirman, Chief

Document Service Branch

Central Intelligence Agency

Attn: CRS/DPSD/DSB/IAS/ 409779/DB

Washington, DC 20505

V. P. Bond

Brookhaven National Laboratory Upton, Long Island, NY 11973
Leo Bustad, Dean

College of Veterinary Medicine

Washington State University

Pullman, WA 99163

Chief

Game Management Division

Department of Game

500 North Capitol Way

01 ympia, WA 98501

Council on Environmental

Quality

72 Jackson Place, N.W.

Washington, DC 20005

J. J. Davis (2)

Assistant Director of Research

Nuclear Regulatory Commission

Washington, DC 20545

H. Daw

Director, Division of Health, Safety and Waste Management

International Atomic Energy

Agency

Vienna 1, Kaerntnerring 11,

Austria

Department of the Environment Fisheries and Marine Service

Canada Centre for Inland

Waters

Great Lakes Biolimnology Lab.

P0 Box 5050

867 Lakeshore Road

Burlington, Ontario 1.7R 4A6

Canada

Department of the Environment Fisheries and Marine Service Marine Ecology Laboratory

Bedford Institute

P0 Box 1006

Dartmouth, Nova Scotia B2Y 4 A2.

Canada

Director

Commissariat a l'Energie

Atomique

Centre d' Etudes

Nucleaires de Fontenay-aux-

Roses (Seine)

France

Director

Commonwealth Scientific and

Industrial Research

Organization

Aspendal, Victoria, Australia 


\author{
Director \\ Institute of Geological \\ Sciences \\ Exhibition Road \\ South Kensington \\ Long, SW-7 2DE \\ United Kingdom

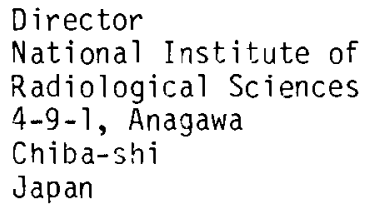

Director

National Institute of

Radiological Sciences

4-9-1, Anagawa

Chiba-shi

Japan

Director, Sea Grant Programs University of Southern Calif. University Park

Los Angeles, CA 90007

Director

State Department of Ecology

Aquatic Pollution Control

01 ympia, WA 98501

Director

William F. Clapp Laboratories

Washington Street

PO Box 1637

Duxbury, MA 02332

G. W. Dolphin

National Radiological

Protection Board

Harvel1, Didcot, Berks

Oxfordshire OXII ORQ

Engl and

D. Edgington

Argonne National Laboratory

9700 South Cass Avenue

Argonne, IL 60439

Editor

Audubor Magazine

National Audubon Society

1130 - 5th Avenue

New York, NY 10028

Education and Information

Section

Health and Physics Division

Oak Ridge National Laboratory

Oak Ridge, TN 37830

Eutrophication Information

Program

Water Resources Center

University of Wisconsin

1324 Dayton Street

Madison, WI 53706

Fish Commission of Oregon

Research Headquarters

Route 2, Box 31-A

Clackamas, OR 97015
N. A. Frigerio

Argonne National Laboratory

9700 South Cass Avenue

Physical and Biological

Research Division

Argonne, IL 60439

P. F. Gustafson

Argonne National Laboratory

9700 South Cass Avenue

Argonne, IL 60439

J. Harley

Health and Safety Laboratory

US Atomic Energy Commission

375 Hudson Street

New York, NY 10014

J. W. Healy

Los Alamos Scientific

Laboratory

Iniversity of California

P0 Box 1563

Los Alamos, NM 87545

C. L. Kar 1

National Lead Company of Ohio

PO Box 39158

Cincinnati, $\mathrm{OH} 45239$

Librarian, Building 465

Atomic Energy Research

Establishment

Harwe 11, Didcot

OXON OXII ORD,

England

Librarian

Australian AEC

River ina Laboratory

P0 Box 226, Deniliquin

New South Wales

Australia 2710

Librarian

Battelle Memorial Institute

Columbus Laboratories

505 King Avenue

Columbus, $\mathrm{OH} 53201$

Librarian

Jo int Center for Graduate

Study

100 Sprout Road

Richland, WA 99352

Librarian

Research Library,

Reference Section

Brookhaven National Laboratory

Upton, Long I sland, NY 11973

Librarian

Centre d' Etudes

Nucleaires de Saclay

PO Box 2, Saclay

Fig-sur-Yvette (S\&0)

France
Librarian

Commonwealth Scientific and

Industrial Research

Organization

314 Albert Street

PO Box 89

East Melbourne, Victoria

Australia 3002

Librarian

Directorate of Fisheries

Research

Ministry of Agriculture, Fisheries and Food Laboratory Lowestoft, Suffolk,

England NR33 OHT

Librarian

Lawrence Radiation Laboratory

University of Cal ifornia

Technical Information Dept.,

$1-3$

PO Box 808

Livermore, CA 94550

Librarian

Los Alamos Scientific

Laboratory

PO Box 1663

Los Alamos, NM 87544

Librarian

Simon Fraser University

Acquisition

Division-Monographs

Burnaby 2, British Columbia

Canada

Librarian

World Meteorological

Organization

Geneva, Switzer land

A. M. Marko

Director

Atomic Energy of Canada Ltd.

Biology and Health Physics

Division

Chalk River Nuclear

Laboratories

Chalk River, Ontario KOJ IJO

Canada

J. W. McCaslin

INEL, Aerojet Nuclear

550 Second Street

Idaho Falls, ID 8340 I

Roger 0. McClellan

Inhalation Toxicology

Research Institute

Lovelace Foundation for

Medical Education and Research P0 Box 5890

Albuquerque, NM 87115

C. B. Meinhold

Brookhaven National Laboratory Upton, Long Is land, NY 11973 
M. L. Mendelsohn

University of California

Lawrence Livermore Laboratory

P0 Box 808

Livermore, CA 94550

W. A. Mil1s, Director

Division of Criteria and

Standards

Office of Radiation Program

Environmental Protection

Agency

Rockville, MD 20852

J. Z. Minczewski

International Atomic Energy

Agency

Vienna 1 , Kaeratenerring 11 , Austria

W. R. Ney

Executive Director

National Council on Radiation

Protection and Measurements

7910 Woodmont Avenue

Suite 1061

Washington, DC 20014

C. M. Patterson

E. I. DuPont de Nemours

and Company

Savannah River Plant

Aiken, SC 29801

R. S. Pau1

Battelle Memorial Institute

Columbus Laboratories

505 King Avenue

Columbus, OH 53201

David Rall, Director

HIEHS

P0 Box 12233

Research Triangle Park, NC 27709

J. E. Rasmussen

Battelle Human Affairs

Research Centers

4000 N. E. 41 st Street

P0 Box 5395

Seattle, WA 98105

C. R. Richmond

Oak Ridge National Laboratory

PO Box X

Oak Ridge, TN 37830

R. E. Rowl and

Argonne National Laboratory

9700 South Cass Avenue

Argonne, IL 60439

M. Rzekiecki

Commissariat a l'Energie

Atomique

Centre d' Etudes

Nucleaires de Cadarache

BP n 13-St. Paul

Les Durance, France
Peter K. Shen, Director

Joint Center for Graduate Study

100 Sprout Road

Richland, WA 99352

W. K. Sinclair

Argonne National Laboratory

9700 South Cass Avenue

Argonne, IL 60439

D. Smith

Environmental Protection

Agency

Washington, DC 20460

K. A. Smith

Sandia Laboratories

PO Box 5800

Albuquerque, NM 87115

F. D. Sowby

International Commission on

Radiological Protection

clifton Avenue

Sutton, Surrey

England

E. G. Struxness

Oak Ridge National Laboratory

Oak Ridge Operations Office

PO Box $X$

Dak Ridge, TN 37830

Technical Information Service Room 773A

Savannah River Laboratory

E. T. duPont de Nemours and Co. Aiken, SC 29801

G. L. Voelz

University of California

Los Alamos Scientific

Laboratory

P0 Box 1663

Los Alamos, NM 87545

E. Wall auschek

ENEA (OECD) Health and

Safety office

38 , Bivd. Suchet

Paris IVI,

France

J. M. Whalen

Teledyne Geotech

PO Box 28277

Dallas, TX 75228

R. C. Yoder

Rockwell International

P0 Box 888

Golden, C0 80401
Individuals

T. M. Albert (3)

Director, Office of

Environmental

Informat ion Systems

Washington, DC 20545

Francis Allen

EPA Water Quality office

Washington, DC 20503

D. R. Anderson

Sandia

Alburquerque, NM 87104

G. Anderson

Dept. of 0ceanography

University of Washington

Seattle, WA 98105

D. B aumgartner

Environmental Protection

Agency

NERC

200 S.W. 35 th

Corvallis, OR 97330

V. T. Bowen

Woods Hole Oceanographic

Institute

Woods Hole, MA 02543

Wallace Broecker

Lamont Geological Observatory

Columbia University

Palisades, NY 10964

R. S. Bruce

Agricultural Research Council

Letcombe Laboratory

Wantage, Oxon 0x129JT

England

J. T. Callahan

Associate Program Director Ecosystems Studies Program National Science Foundation Washington, DC 20545

Roy Carpenter

Department of Oceanography University of Washington

Seattle, WA 98105

Douglas Chapman, Dean

College of Fisheries University of Washington

Seattle, WA 98115

Gordon Chesters, Director Water Resources Center University of Wisconsin Madison, WI 53706 
E. E. Clark, Division

Director

National Science Foundation

Division of Biological and

Medical Sciences

Washington, DC 20550

Fred Cleaver,

Program Director

National Marine Fisheries

Service

Columbia Fisheries Program

Office

811 NE Oregon Street

Portland, OR 97208

Roland C. Clement,

$\checkmark$ ice President

National Audubon Society

11305 th Avenue

New York, NY 10028

James W. Cobble, Dean

Graduate Division

San Diego State University

San Diego, CA 92115

S. Davis

Department of Health,

Education and Welfare

Division of Pharmacology,

Internal Medical Branch

South Agr. 5148

Washington, DC 20204

Richard Dolbeer

U.S. Bureau of Sport

Fisheries and Wildiife

P.0. Box 2097

Sandusky, $\mathrm{OH} 44870$

Henry C. Eichhorn

Acting Chief, Biology Branch

Water Quality Engineering

Division

U.S. Army Environmental

Hygiene Agency

Aberdeen Proving Ground,

MD 21010

R. J. Engelman

National Oceanic Atmospheric

Adminstration

Boulder, CO

R. Eppley

Scripps Institute of 0ceanography

La Jolla, CA 92037

G. A. Feigen

Dept. of Physiology

Stanford University

Palo Alto, CA 94305
R. H. Filby, Director

Nuclear Radiation Center Washington State University

Pullman, WA 99163

J. F. Frankl in

Forest Science Laboratory

Oregon State University

P.0. Box 887

Corvallis, OR 97730

Norman French

Natural Resources Ecology Lab.

Colorado State University

Fort Collins, c0 80521

Arnold Gahler

Supervisory Chemist

Environmental Protection

Agency

Region $X$

15345 N.E. 36th Street

Redmond, WA 98052

Norman R. Glass,

Director

Environment al Protection

Agency

NERC

200 S.W. 35th Street

Corvallis, OR 97330

Ed Goldberg

Scripps Institute of

Oceanography

La Jolla, CA 92037

Jack R. Gould

American Petroleum Institute

1801 K Street N.W.

Washington, DC 20006

Jack Hammerton

Department of Game

600 N. Capitol Way

01 ympia, WA 98504

D. W. Hayne

Department of Experimental

Statistics

North Carolina State

University

Box 5457

Raleigh, NC 27607

W. L. Hayton

College of Pharmacy

Washington State

University

Purlman, WA 99164

Edward Held

Nuclear Regulatory

Commission

Washington, DC 20545
H. R. Holt

Policy Analyst/System

Analysis Office, EPA

Washington, DC 20545

G. P. Holland, Director Entomology Research Institute

Central Experiment Farm

Canada Dept. of Agriculture

Ottawa, Canada

Gwyneth Parry Howells

Central Electricity, Research

Laboratories

Leatherhead, Surrey

Engl and

E. W. Humphrys

Senior Advisor

Electrical Energy

Dept. of Energy,

Mines and Resources

Ottawa, Ontario KIA OE4

Canada

K. L. Jackson

Chairman of Radiological

Sciences

D-218 Health Sciences

University of Washington

Seattle, WA 98195

Benjamin A. Jayne,

Director

Center for Quantitative

Science in Forestry,

Fisheries and Wildlife

3737 15th Avenue N.E.

Seattle, WA 98195

Everett $A$. Jenne Water Resources Division

U.S. Geological Survey

345 Middlefield Road

Men lo Park, CA 94025

G. J. Kenagy

Dept. of Zoology

University of Washington

Seattle, WA 98195

Donald Kennedy,

Chairman

Dept. of Biological Sciences

Stanford University

Stanford, CA 94305

Thomas Kimball

Executive Director

National Wildlife Federation

1412 Sixteenth Street, N.W.

Washington, DC 20036 
John W. Kincheloe

U.S. Fish and Wildiife

Division of River Basin

Studies

919 N.E. 19th

Portland, OR 97232

Betty Klepper

USDA

Ag. Research Service

Columbia Plateau Conservation

Research Center

Box 370

Pendleton, OR 97801

Phillip LaFleur

Nuclear Reactor Laboratory

National Bureau of Standards

Gaithersburg, MD 20760

Richard W. Latimer, Director Arctic Environmental Research Laboratory, EPA

College, AK 99701

Richard $M$. Lemmon

Lab. of Chemical Biodynamics

Lawrence Berkeley Laboratory

University of California

Berkeley, CA 94720

John D. Lunz

Environmental Resources

Division

Department of the Army

Waterways Experiment Station

Corps of Engineers

PO Box 631

Vicksburg, MS 39180

D. Malins

National Marine Fisheries

Service

Seattle, WA

Bernard Manowitz

Radiation Division

Brookhaven National

Laboratory

Upton, Long Island, NY 11973

0. Doyle Markham

Environmental Sciences

Branch

Health Services Laboratory

U.S. DOE

PO Box 2108

Idaho Falls, ID 83401

D. Menzel

Skidaway Oceanographic

Institute

University of Georgia

Savannah, GA 31406
K. 7. Morgan

School of Nuclear Engineering

Georgia Institute of

Technology

Atlanta, GA 30332

William Morse

Wildlife Management

Institute

1617 N.E. Brazee Street

Portland, OR 97212

Roger Del Moral

Dept. Botany

Ak-10

University of Washington

Seattle, WA 98195

C. H. Mortimer,

Director

Center Great Lakes Studies

University of Wiscons in

Milwaukee, WI 53201

Donald Mount, Director

EPA Environmental Research

Center

6201 Congdon Blvd.

Duluth, MN 55800

R. E. Nakatani

Assistant Director

Fisheries Research Institute

$260 \mathrm{Fisheries}$ Center

University of Washington

Seattle, WA 98105

J. Nash

Pol icy Analyst

EPA

Washington, DC ?20545

Professor J. M. Neuhold

Department of Wildlife

Resources

Utah State University

Logan, UT 84321

I. Ophel

Atomic Energy of Canada Ltd.

Chalk River, Ontario

Canada

Gordon Orians

Professor of Zoology

148 Johnson Hal1

University of Washington

Seattle, WA 98105
C. L. Osterberg,

Director

International Atomic Energy

Agency

International Laboratory

Marine Radioactivity

Oceanographic Museum

Monaco-Vil1e

Principality of Monaco

N. Pace, Director

White Mountain High

Altitude Research Laboratory

University of California

Berkeley, CA 94720

Harold T. Peterson, Jr.

Dept. of Health, Education and Welfare

Bureau of Radiological Hea 1 th

Consumer Protec:ion and

Environmental Health Service

Rockville, MD 20852

William L. Petrie

National Research Council

2101 Constitution Avenue

Washington, DC 20418

Warren Piver

NIEHS

PO Box 12233

Research Triangle Park

NC 27709

Charles F. Powers, Chief

Technology Development Section

National Eutrophication

Research Program

Nationa1 Environmenta1

Research Center

200 S.W. 35th Street

Corvallis, OR 97330

A. Preston

Ministry of Agriculture, Fisheries, and Food

Directorate of Fisheries

Research

Lowestoft, Suffolk

England NR 330HT

Craig Roberts

Asst. Director

Site and Health Standards

Nuclear Regulatory Commission

Washington, DC 20555

Melvin Schachter

Department of Physiology

University of Alberta

Edmonton, Alberta

Canada 
W. Schikarski

Kernfor schungazentrum

Karlsruhe

Institut fur Angewandte System

Technik und Reaktonphysik

Postfach 3640

$75 \mathrm{Kar} 7$ sruhe, Germany

Eric Schnieder

National Marine Water

Quality Laboratory-EPA

PO Box 277

West Kingston, RI 02982

Vincent Schultz

Department of Zoology

Washington State University

Pullman, WA 99163

Allyn H. Seymour

College of Fisheries

University of Washington

Seattle, WA 98105

Clifford Smith

Regional Director

EPA Region Office

1206 6th Avenue

Seattle, WA 98101

Mike Smith, Director

Savannah River Ecology

Laboratory

University of Georgia

Savannah River Plant

PO Box A

Aiken, SC 29801

L. F. Stickel

Patuxent Wildlife Research

Center

Laure 1, MD 20810

Lee 0. Tiffin

Agricultural Environmental

Quality Institute

Beltsville Agricultural

Research Center

Beltsville, MD 20705

E. W. Ungar, Director

Columbus Laboratories

Battelle Memorial Institute

$505 \mathrm{King}$ Avenue

Columbus, $\mathrm{OH} 43201$

G. M. Van Dyne

Colorado State University

Fort Collins, CO 80521

R. C. Vetter

National Academy of

Sciences

2101 Constitution Avenue

Washington, DC 20037
Frederic H. Wagner

Ecology Center

Utah State University

Logan, UT 84321

Charles L. Weaver,

Director

Division of Environmental

Radiation

Dept. of Health, Education

and Welfare

Consumer Protection and

Environmental Health

Service

Rockville, MD 20852

Ward Whicker

Colorado State University

Fort Collins, CO 805? 1

Hill Williams

Science Writer

Seattle Times

Box 70

Seattle, WA 98111

David Willis, Chairman

Dept. General Sciences

Oregon State University

Corvallis, OR 97331

W. B. Wrenn

Tennessee Valley Authority

Division of Forestry,

Fisheries, and Wildife

Decatur, AL 35601

\section{ONSITE}

DOE Richland Operations

Office (7)

P. F. X. Dunnigan

J. L. Landon

H. E. Ransom

F. R. Standerfer

M. W. Tiernan

J. D. White

Hanford Environmental Health Foundation (3)

B. D. Breitenstein

P. A. Fugua

W. D. Norwood

Pacific Northwest Laboratory

(185)

T. W. Ambrose

W. J. Bair (20)

F. P. Brauer

N. E. Carter

D. B. Cear lock
C. H. Connally

L. C. Counts

H. Drucker (2)

L. L. Eberhardt (2)

C. E. Elderkin

J. R. Eliason

G. W. R. Endres

J. E. Fager

S. J. Farmer

J. W. Finnigan

J. J. Fix

R. F. Foster

J. J. Fuquay

C. I. Gibson (10)

W. Hanson (2)

A. J. Haverfield

D. L. Hessel

F. P. Hungate

J. C. Langford

H. V. Larson

S. Marks

R. P. Marshall

L. E. Nero

J. M. Nielson

R. E. Nightingale

D. E. Olesen

H. M. Parker

R. W. Perkins (5)

L. L. Rader

L. A. Rancitelli (5)

W. D. Richmond

W. H. Rick ard (10)

D. E. Robertson

W. B. Silker

C. L. Simpson

J. R. Sletager

J. K. Soldat

J. A. Strand (10)

J. K. Tarantino

W. L. Templeton (2)

C. W. Thomas

R. C. Thompson

J. M. Thorp

C. M. Unruh

B. E. Vaughan (100)

W. R. Wiley

R. E. Wildung (10)

Biology Library (2)

Technical Information (5)

Publishing Coordination (2)

\section{Battelle Seattle}

G. W. Duncan

J. Herbert

J. McDonald

S. Nealey

J. E. Rasmussen 
